RODRIGO OLIVEIRA DE FARIA

\title{
NATUREZA JURÍDICA DO ORÇAMENTO E FLEXIBILIDADE ORÇAMENTÁRIA
}

\author{
DISSERTAÇÃO DE MESTRADO
}

ORIENTADOR: PROFESSOR JOSÉ MAURICIO CONTI

FACULDADE DE DIREITO - USP

São Paulo

2009 
RODRIGO OLIVEIRA DE FARIA

NATUREZA JURÍDICA DO ORÇAMENTO E FLEXIBILIDADE ORÇAMENTÁRIA

Dissertação apresentada à Faculdade de Direito da Universidade de São Paulo para obtenção do

Título de Mestre em Direito

Área de Concentração:

Direito Financeiro

Orientador: Prof. Dr. José Maurício Conti 
Nome: FARIA, Rodrigo Oliveira de

Título: Natureza Jurídica do Orçamento e Flexibilidade Orçamentária

Dissertação apresentada à Faculdade de Direito da Universidade de São Paulo para obtenção do título de Mestre em Direito

Aprovado em:

Banca Examinadora

Prof. Dr.

Instituição:

Julgamento:

Assinatura:

Prof. Dr.

Instituição:

Julgamento:

Assinatura:

Prof. Dr.

Instituição:

Julgamento:

Assinatura: 
Agradeço a toda minha família pelo apoio incondicional, sem o qual esta jornada não teria sido possível. À Fernanda devo o amor, carinho e incentivo permanentes, que me fortalecem em face dos desafios. À pequena Cecília, penhoro a alegria do ninho doméstico. 
As leis, em seu significado mais extenso, são as relações necessárias que derivam da natureza das coisas; e, neste sentido, todos os seres têm suas leis; a Divindade possui suas leis, o mundo material possui suas leis, as inteligências superiores ao homem possuem suas leis, os animais possuem suas leis, o homem possui suas leis. 


\section{RESUMO}

FARIA, Rodrigo Oliveira de. Natureza Jurídica do Orçamento e Flexibilidade Orçamentária. 2009. 288 f. Dissertação (Mestrado) - Faculdade de Direito, Universidade de São Paulo, São Paulo, 2009.

O objeto central deste trabalho é a investigação da natureza jurídica da Lei de Orçamento em consonância com o ordenamento jurídico brasileiro. Tradicionalmente, tem sido defendido o entendimento de que nossa lei orçamentária possuiria a natureza de mera lei formal, visto que o Poder Executivo não se encontraria obrigado a executar o Orçamento tal como aprovado pelo Poder Legislativo. Nesta dissertação, defende-se ponto de vista oposto à corrente majoritária existente no meio jurídico brasileiro. Por meio do confronto entre as premissas e postulados firmados pela teoria clássica do Orçamento, que tem em Paul Laband seu maior expoente, e o tratamento conferido pela sistemática orçamentária brasileira, procura-se indicar a insuficiência da tese da lei formal. A dignidade constitucional do Orçamento, que possui seus contornos extraídos direta e centralmente da Constituição da República dá a medida da importância da lei orçamentária em nosso meio. Defende-se que a citada Lei possui uma multiplicidade de comandos, revelando em seu corpo não somente autorizações, como também proibições e determinações ou obrigações. São os fins que emprestam à Lei de Orçamento o condão de obrigatoriedade. Destarte, os objetivos e metas fixados na peça orçamentária possuem nítido caráter obrigatório, ao vincular toda a administração pública à sua consecução e alcance. As dotações orçamentárias, por sua vez, enfeixam o caráter de limites financeiros autorizados em face da incidência dos princípios constitucionais da eficiência, eficácia, economicidade e efetividade. Os recursos financeiros são os meios que permitem o alcance dos fins, contudo, são os fins que são obrigatórios. Assim, a denominação lei de meios põe ênfase naquilo que não indica a real natureza da Lei de Orçamento. As leis orçamentárias são leis de fins e, dessa forma, a medida do seu cumprimento somente se revela em face do alcance dos objetivos que se lhe encontram associados.

Palavras-chave: orçamento; lei orçamentária; natureza jurídica; lei formal; lei material. 


\begin{abstract}
FARIA, Rodrigo Oliveira de. The Juridical Nature of the Budget and Budget Flexibility. 2009. 288 f. Dissertation (Master's Degree) - Faculty of Law, University of São Paulo, São Paulo, 2009.

The purpose of this dissertation is to investigate the juridical nature of the Budget Law in accordance with the Brazilian juridical ordainment. Traditionally, the understanding that our budget law has a mere formal law nature has been advocated as the Executive branch is not obliged to comply with the Budget as passed by the Legislative branch. In this dissertation a contrary point of view to the existing major tendency in the juridical environment is defended. Through confronting the premises and postulates backed up by the Budget classical theory, whose main exponent is Paul Laband, and the treaty conferred by the Brazilian budget systematics, the insufficiency of the formal law thesis is indicated. The constitutional dignity of the budget, whose outlines were directly and centrally extracted from the Constitution of the Republic, sets the importance of the budget law in our environment. It is defended that the Budget Law has a multiplicity of commandments, not only revealing authorizations in its scope, but also prohibitions, and determinations, or obligations. It is the ends that lend the Budget Law the prerogative of obligatoriness. Thus, the objectives and aims established in the budget piece have a clear obligatory character, linking all the public administration to its execution and attainment. Budget dotations, however, bundle up the character of authorized financial limits, in the light of the constitutional principles of efficiency, efficacy, economicity and effectiveness. The financial resources are the means that allow reaching the ends; however, it is the ends that are obligatory. Thus, the term law of means places emphasis on what does not indicate the real nature of Budget Law. Budget Laws are laws of ends, and thus, the measure of its accomplishment can only be gauged after reaching the goals with which they are associated.
\end{abstract}

Keywords: budget; budget law; juridical nature; formal law; material law. 


\section{SUMÁRIO}

INTRODUÇÃO

p. 10

1. EVOLUÇÃO HISTÓRICA DO ORÇAMENTO PÚBLICO p. 14

1.1 As Transformações do Orçamento Público p. 14

1.2 O Orçamento Público nas Constituições brasileiras $\quad$ p. 21

1.2.1 A concepção orçamentária da Constituição de $1988 \quad$ p. 26

1.3 Orçamento como instrumento gerencial p. 31

$\begin{array}{ll}1.4 \text { Orçamento como instrumento de política fiscal p. } 40 & \text { p. }\end{array}$

2. O ORÇAMENTO NO DIREITO COMPARADO p. 46

2.1 O Orçamento no modelo estadunidense p. 46

2.2 O Orçamento no ordenamento chileno p. 58

2.3 O Orçamento no ordenamento jurídico mexicano p. 65

2.4 O Orçamento no sistema orçamentário português $\quad$ p. 75

$2.5 \mathrm{O}$ Orçamento no ordenamento jurídico francês $\quad$ p. 83

3. A TEORIA CLÁSSICA DO ORÇAMENTO p. 91

3.1 A Lei do Orçamento em Paul Laband p.91

3.2 O Orçamento em Gaston Jèze $\quad$ p. 106

3.3 O Orçamento em Léon Duguit p. 113

4. NATUREZA JURÍDICA DA LEI DE ORÇAMENTO NO ORDENAMENTO BRASILEIRO

p. 119

4.1 O Orçamento Impositivo p. 120

4.2 Unidade e Pluralismo na Lei de Orçamento p. 142

$\begin{array}{ll}4.3 \text { Metas fiscais e seu conteúdo jurídico } & \text { p. } 145\end{array}$

4.4 Conteúdo jurídico do Orçamento das Receitas p. 149

4.5 Conteúdo jurídico do Orçamento das Despesas p. 156

4.5.1 Fundamento jurídico das despesas p. 156

4.5.2 Dotações orçamentárias e seu conteúdo jurídico p. 165

$\begin{array}{ll}\text { 4.5.3 Programas orçamentários e Metas programáticas } & \text { p. } 172\end{array}$

$\begin{array}{ll}\text { 4.5.3.1 Estruturação por programas } & \text { p. } 172\end{array}$ 
4.5.3.2 Conteúdo jurídico dos programas orçamentários

p. 181

4.6 Conflitos entre objetivos fiscais e programáticos

p. 191

4.7 Autorização para créditos suplementares e alterações da Lei de Orçamento

p. 200

4.8 Condicionamento da legislação permanente pelas leis orçamentárias

p. 210

4.9 Limites da atuação do Parlamento na discussão e aprovação do Orçamento

p. 217

4.10 Infrações à Lei de Orçamento e sua responsabilização

p. 234

4.11 Validade do Duplo Conceito de Lei e enquadramento da Lei de Orçamento

p. 247

4.11.1 Validade atual da Teoria do Duplo Conceito de Lei

p. 247

4.11.2 Enquadramento jurídico da Lei de Orçamento no Brasil

p. 257

4.12 A flexibilidade como elemento integrante da natureza da Lei de Orçamento

p. 265

CONCLUSÕES

p. 269

REFERÊNCIAS BIBLIOGRÁFICAS

p. 277 


\section{INTRODUÇÃO}

As espécies normativas não se apresentam idênticas em nosso ordenamento jurídico. Ao contrário, revelam peculiaridades e traços próprios que lhes conferem identidade. A investigação da identidade e da essência particular da Lei de Orçamento representa o objeto deste estudo.

O exame da natureza jurídica da citada Lei é bem mais amplo do que uma mera afirmação de que se trata de lei formal ou de lei material. Na verdade, o itinerário a ser percorrido para que se possa defender uma ou outra posição não prescinde de uma perquirição mais profunda acerca dos postulados e premissas que se encontram associados a cada uma das teses formuladas.

Destarte, procura-se, neste trabalho, responder a questões diversas, que oferecem os contornos próprios das Leis de Orçamento, revelando sua complexidade e multiplicidade. A mutabilidade da Lei de Orçamento faz dela uma peça de ficção? Ou se configura, justamente, em um dos seus traços dominantes? A flexibilidade é necessária ao cumprimento dos fins visados pela Lei de Orçamento?

A Lei de Orçamento possui uma natureza de mera autorização? Ou existem comandos diferenciados em seu corpo normativo, por meio dos quais se veiculam proibições, autorizações e determinações? Em que medida e extensão existem tais comandos? Onde se encontram situados?

A invenção brasileira do Orçamento Impositivo ou Mandatório apresenta sentido real? Ou se trata de uma falácia, que termina por encobrir e mascarar a existência de obrigatoriedade no Orçamento?

A Lei de Orçamento possui realmente a natureza jurídica de lei formal? Configurase, dessa forma, como um ato administrativo que enfeixa apenas aparentemente a forma de lei? Há sentido, em nossos dias, em se insistir na dicotomia do duplo conceito de lei?

Essas são algumas questões que esta dissertação se propõe a responder. Constatase-se, inicialmente, a complexidade dos questionamentos associados à Lei de Orçamento, razão pela qual se torna imprescindível uma ampla análise de seus contornos característicos.

Motivam a análise da natureza essencial das leis orçamentárias duas ordens principais de razões. Em primeiro lugar, o contraste entre a exiguidade de exames jurídicos sobre a Lei de Orçamento e a relevância ímpar desta para o funcionamento da 
Administração Pública. Em segundo lugar, a opinião corrente de que tais leis seriam ordinariamente descumpridas pelo Poder Executivo, caracterizando-se como verdadeiras "peças de ficção", somada ao entendimento generalizado de que tais estatutos seriam meras leis formais autorizativas.

Por meio do exame dos contornos das leis orçamentárias no ordenamento jurídico brasileiro, pretende-se evidenciar sua natureza jurídica e peculiaridades, aferindo-se, juridicamente, a validade e pertinência das hipóteses levantadas acerca destas leis.

Defende-se, nesta dissertação, que as Leis de Orçamento são os estatutos que presidem a condução do Governo e imprimem o direcionamento da Administração Pública, visando a concretização dos princípios e valores plasmados na Constituição Federal de 1988. Possuem um conteúdo próprio, especial e determinado, que as diferenciam de todas as outras espécies normativas.

Não lhes corresponde, todavia, um cunho meramente formal, posicionamento doutrinário amplamente majoritário na comunidade jurídica brasileira. Ao contrário, tais leis orçamentárias são leis materiais, de nítido caráter obrigatório.

Contudo, os estudiosos que se debruçaram sobre o tema buscaram detectar tal obrigatoriedade em elementos que, na verdade, não revelam o real preceito jurídico plasmado nestas leis. $\mathrm{O}$ senso comum indica que apenas a obrigatoriedade de execução das despesas previstas nas leis orçamentárias, pelo Executivo, daria a medida do caráter mandatório da Lei de Orçamento. Sendo os créditos orçamentários meramente autorizativos, não haveria nenhum caráter cogente na peça orçamentária.

Em que pese tal entendimento, procura-se demonstrar juridicamente que são os objetivos consignados nas leis orçamentárias que revelam, efetivamente, a sua obrigatoriedade. Os objetivos estampados nessas leis vinculam toda a Administração Pública e mobilizam todo o aparelho de Estado no sentido de sua perseguição. Portanto, o real cumprimento das Leis de Orçamentorevela-se no atingimento dos objetivos previstos pelos programas, de acordo com critérios de eficiência, eficácia, efetividade e economicidade.

A presente dissertação encontra-se estruturada em quatro capítulos. O primeiro trata da evolução histórica do Orçamento Público, suas origens, seu desenvolvimento e as transformações sofridas pela peça orçamentária. Tais modificações realçam sua paulatina instrumentalização gerencial, por meio da associação de técnicas modernas da administração, e sua instrumentalização fiscal, por intermédio da qual se lhe incorporam 
fins de política fiscal do Governo, as quais se associam à tradicional função de controle político do Poder Legislativo sobre o Executivo.

O segundo capítulo enfrenta a análise comparativa do tratamento conferido por outros países ao Orçamento Público. O exame do direito comparado permite a verificação das modernas tendências existentes, dos distintos delineamentos conferidos à Lei de Orçamento, bem como de certas pecularidades. Realçam-se, nesse ponto, o direcionamento ao Orçamento por Resultados, a preocupação e incorporação de objetivos fiscais, bem como o generalizado tratamento das dotações orçamentárias como limites máximos de despesas, elementos essenciais para que a investigação da natureza jurídica do Orçamento no ordenamento brasileiro possa ser enfrentada a contento.

No terceiro adentra-se no exame da Teoria Clássica do Orçamento, que possui como vigas mestras as contribuições doutrinárias de Paul Laband, Gaston Jèze e Léon Duguit. Esses estudos fornecem as premissas e balizas que nortearão os debates sobre a natureza jurídica da Lei de Orçamento no ordenamento jurídico brasileiro, razão pela qual são expostos pontos centrais dessaselaborações doutrinárias. Há, ainda, nesse capítulo, as formulações da teoria da lei formal, da atomização do exame da Lei de Orçamento, do caráter de legislação vinculada do Orçamento e da supremacia do Poder Executivo em face do Legislativo no processo de aprovação da Lei.

Do quarto capítulo, constao debate a respeito da Lei de Orçamento no ordenamento jurídico brasileiro, bem como as premissas assentadas pelos autores clássicos. Discute-sea pertinência e validade dessas reflexões diante do tratamento conferido pelo ordenamento positivo brasileiro. Ademais, são trazidas as reflexões e contribuições doutrinárias de autores mais modernos acerca dos postulados da teoria clássica, incorporando-as às discussões dos temas relacionados ao caso brasileiro.

As seções em que se apresenta dividido o último capítulo representam a seleção de temas centrais encontrados nos exames feitos pelos autores da teoria clássica e por meio dos quais se pretende compor o panorama geral que permitirá traçar os delineamentos e conclusões a respeito da Lei de Orçamento brasileira.

Um último ponto é necessário nessas considerações introdutórias: a relevância do tema. Paradoxalmente, um assunto de tamanha importância para a comunidade jurídica tem sido relegado ao segundo plano. Desse modo, importa a modificação desse tratamento. É de fundamental importância que os estudos jurídicos joguem luz sobre as leis 
infraconstitucionais mais importantes em nosso País. Nesse sentido, este trabalho foi realizado, ainda, com o objetivo de contribuir para a transformação desse cenário. 


\section{EVOLUÇÃO HISTÓRICA DO ORÇAMENTO PÚBLICO}

\subsection{As Transformações do Orçamento Público}

A procura pela figura do Orçamento somente pode ser feita posteriormente às revoluções liberais dos séculos XVII e XVIII, ou seja, depois do advento do constitucionalismo ${ }^{1}$. Com o advento das instituições de governo representativo, inicia-se o desenvolvimento do sistema orçamentário no continente europeu ${ }^{2}$.

A evolução do controle parlamentar sobre o Poder Executivo termina por levar ao surgimento do orçamento público. Por isso mesmo, as instituições orçamentárias remetem, em seus primórdios, ao progressivo controle que o Poder Legislativo estabelece em face das finanças públicas.

Os primórdios dessa evolução, na Grã-Bretanha, são retratados por Burkhead: “As origens do sistema orçamentário na Grã-Bretanha remontam ao advento do controle do Parlamento sobre a Coroa. O desenvolvimento do orçamento expressa, em parte, o crescimento do controle popular sobre o rei"3.

O embrião das instituições orçamentárias, no primeiro momento, é o controle da tributação excessiva, estabelecido por meio dos embates travados entre o Rei e o Parlamento, que resultaram na fixação de limites ao poder do Fisco.

Exatamente por isso, a anualidade orçamentária surgirá mesclada com a anualidade tributária: o Legislativo exercerá o controle político sobre o Executivo pela renovação anual da permissão para a cobrança dos tributos ${ }^{4}$.

O controle das despesas efetuadas pelo Governo somente surgirá mais tarde, com o progressivo controle do Legislativo sobre as finanças públicas. Inicialmente, os Parlamentos não estavam preocupados com as despesas a serem efetuadas pela Coroa. $\mathrm{O}$ controle sobre os detalhes da despesa e sua especificação foi estabelecido posterior e gradualmente, começando pelos gastos relativos ao Exército, Marinha e equipamentos militares 5 .

Como salienta Aliomar Baleeiro,

\footnotetext{
${ }^{1}$ TORRES, Ricardo Lobo. Tratado de Direito Constitucional Financeiro e Tributário. Vol. V. O Orçamento na Constituição. $2^{\mathrm{a}}$ ed. Rio de Janeiro: Renovar, 2000, p. 3.

${ }^{2}$ BURKHEAD, Jesse. Orçamento Público. Rio de Janeiro: Fundação Getúlio Vargas, 1971, p. 9.

${ }^{3}$ Ibid., p. $3 / 4$.

${ }^{4}$ TORRES, Ricardo Lobo, op. cit., p. 269.

${ }^{5}$ BURKHEAD, Jesse, op. cit., p. 4/5.
} 
Pacífico o direito de autorizar as receitas, não foi difícil ao Parlamento britânico obter o reconhecimento de seu poder correlato de também autorizar e controlar as despesas governamentais, discriminados do patrimônio público os haveres pessoais do monarca ${ }^{6}$.

Em 1787, na Grã-Bretanha, com a aprovação da Lei do Fundo Consolidado Consolidated Fund Act -, iniciou-se o registro de todas as receitas e despesas do Governo. Com isso, foi estabelecida a base para uma completa enumeração das atividades financeiras da Coroa. A partir de 1802, passou a ser publicada anualmente uma exposição completa sobre as finanças públicas, que, todavia, ainda não era submetida ao Parlamento.

Como destaca Burkhead, somente a partir de 1822 o Chanceler do Erário passou a apresentar tal exposição ao Parlamento, data esta que marca o início do orçamento, plenamente desenvolvido, na Grã-Bretanha ${ }^{7}$. As exposições, a partir daí, fixavam a receita e a despesa, indicando o déficit ou superávit governamental, juntamente com o plano financeiro do Governo.

$\mathrm{Na}$ França, a partir do Decreto de 17 de junho de 1789, tornou-se princípio fundamental e duradouro de sua prática constitucional que "nenhum imposto pode ser cobrado sem o consentimento da nação". De forma similar ao desenvolvimento do sistema orçamentário britânico, o controle da despesa pela Assembléia Nacional francesa somente foi estabelecido mais tarde que o controle da tributação ${ }^{8}$.

Em meados de 1815, o Governo francês passa a apresentar, anualmente, uma proposta orçamentária que, depois de decretada, se consubstanciava na lei financeira do ano. Nesse período, três características associaram-se a essa sistemática institucional: $1^{\mathrm{a}}$ ) o orçamento com periodicidade anual; $2^{\mathrm{a}}$ ) votação antes do início do ano financeiro e $3^{\mathrm{a}}$ ) apresentação de todas as provisões financeiras necessárias para o exercício que se seguiria ${ }^{9}$.

A importância da difusão das instituições orçamentárias progressivamente desenvolvidas na Inglaterra e na França ao restante do continente europeu é ressaltada pela doutrina:

Há exagero em atribuir-se exclusivamente à Inglaterra e à França o princípio do imposto consentido, mas cabe-lhes, sobretudo à primeira, a difusão das doutrinas e das

\footnotetext{
${ }^{6}$ BALEEIRO, Aliomar. Uma Introdução à Ciência das Finanças. Atualizador Dejalma de Campos. $16^{\mathrm{a}}$ ed. Rio de Janeiro: Forense, 2006, p. 415.

${ }^{7}$ BURKHEAD, Jesse, op. cit., p. 5.

${ }^{8}$ Ibid., p. 10.

${ }^{9}$ Ibid., p. 10.
} 
práticas orçamentárias, que já existiam em estado embrionário em todos os povos europeus. Estes, por efeito de instituições feudais, obrigavam o monarca a pedir a uma assembléia de contribuintes o assentimento para aplicação dos tributos. Os princípios da representação política e da anuência expressa para o imposto, bases do orçamento, já estavam implícitos nessas práticas vetustas que há perto de 1.000 anos se observavam também em Espanha e Portugal ${ }^{10}$.

Como se pode notar, a elaboração da concepção orçamentária deve-se fortemente às disputas políticas travadas entre Monarcas e Parlamentos, antes de tudo. Não existe, nesse momento, a intenção de racionalizar a atividade financeira do Estado, mas, sim, a de proteger os contribuintes dos excessos de tributação. Para Baleeiro:

(...) a origem do orçamento não se prende a elucubrações de técnicos, nem a preocupação de racionalizar a máquina financeira. Uma penosa e multissecular cadeia de lutas políticas tornou a elaboração orçamentária indispensável ao equilíbrio dos interesses antagônicos em volta do poder ${ }^{11}$.

Todas as Constituições dos séculos XIX e XX mencionam a votação do orçamento como atribuição precípua e privativa dos Parlamentos. Profundamente associado com o surgimento das instituições democráticas representativas, o desenho da instituição orçamentária será marcado pelo contexto histórico-político dos respectivos Estados Nacionais e pela ideologia dominante.

Em sua primeira fase, o orçamento clássico ou tradicional encontrava-se informado pelos princípios liberais e pela idéia de que a atividade financeira do Estado deveria ser restrita.

Como destaca Ricardo Lobo Torres:

A Constituição Orçamentária, durante todo o séc. XIX e início do séc. XX, 'constitui' o Estado Fiscal Clássico, ou seja, o Estado Guarda Noturno, que se limita a fazer a guerra, prover a justiça e interferir minimamente sobre a vida econômica e social dos diversos países. A teoria clássica do orçamento, que lhe corresponde, apoia-se na distinção entre lei formal e material ${ }^{12}$.

No mesmo sentido, a lição de José Afonso da Silva aponta que:

Informado pelos princípios do liberalismo, o orçamento tradicional refletia a idéia de que a atividade financeira do Estado deveria restringir-se ao indispensável à satisfação das necessidades primárias do Estado (segurança interna e externa, justiça, etc), vedada qualquer ingerência na ordem econômica e social ${ }^{13}$.

${ }^{10}$ BALEEIRO, Aliomar, op. cit., p. 416.

${ }^{11}$ Ibid., p. 412.

12 TORRES, Ricardo Lobo, op. cit., p. 4/5.

${ }^{13}$ SILVA, José Afonso da. Orçamento-Programa no Brasil. São Paulo: Revista dos Tribunais, 1973, p. 2. 
Em sua fase inicial clássica ou tradicional, o orçamento era mera previsão de receitas e autorização das despesas públicas, sem qualquer preocupação com objetivos econômico-sociais ${ }^{14}$. A teoria orçamentária do Estado Liberal encontrava-se baseada na idéia de equilíbrio entre receitas e despesas ${ }^{15}$. A função do orçamento, neste contexto, é eminentemente política:

A função fundamental do orçamento clássico, historicamente, foi sempre o de assegurar o controle político das atividades governamentais; controle que se fazia através dos órgãos legislativos sobre as atividades financeiras dos órgãos executivos ${ }^{16}$.

Nos seguintes termos, Baleeiro realça a função de controle político e o equilíbrio entre receita e despesa:

Durante os dois primeiros séculos, desde a revolução britânica de 1688, o orçamento, como instrumento político, foi o escudo para defesa dos contribuintes contra os governos. Era, sobretudo, um dique para conter as despesas e, consequentemente, deter o apelo à tributação. Daí a importância sempre prestada ao equilíbrio entre a receita e a despesa $^{17}$.

Portanto, em seus primórdios o orçamento era documento estático de previsão de receitas e autorização de despesas. Somente com as transformações sofridas pelo Estado no decorrer do século XX, assumirá a função de instrumento de intervenção do Estado na economia $^{18}$. Na transformação do Estado Liberal para o Welfare State, o orçamento passa a figurar como a ferramenta por excelência do novo desenho estatal.

O Estado liberal entra em crise por não conseguir atender às reivindicações sociais das classes trabalhadoras, bem como por não conseguir garantir o pleno funcionamento do mercado.

A partir de 1929, com o crash da Bolsa de Nova York e o agravamento da situação financeira mundial, surge a necessidade da intervenção estatal no domínio econômico. O desenvolvimento posterior de toda uma doutrina econômica e filosófica levará ao surgimento do que se convencionou chamar de Estado de Bem-Estar Social - Welfare State.

\footnotetext{
${ }^{14}$ SILVA, José Afonso da, op. cit., p. 1.

15 TORRES, Ricardo Lobo, op. cit., p. 53.

${ }^{16}$ SILVA, José Afonso da, op. cit., p. 2.

${ }^{17}$ BALEEIRO, Aliomar, op. cit., p. 420.

${ }^{18}$ OLIVEIRA, Regis Fernandes de. Curso de Direito Financeiro. São Paulo: Revista dos Tribunais, 2006, p. 305.
} 
Como destaca Ricardo Lobo Torres,

Com a crise do Estado Fiscal no início do séc. XX e com o crescimento do Estado de Bem-estar Social, modificam-se as Constituições Orçamentárias dos diversos países, para agasalhar a intervenção do Estado no domínio econômico e no social. No Brasil, a disciplina constitucional do orçamento se amplia a partir de 1937, para atender à nova orientação política e econômica ${ }^{19}$.

A partir da publicação do livro Teoria Geral do Juro, do Emprego e da Moeda, em 1936, de John Maynard Keynes, passou-se a defender a importância da função estabilizadora do Estado em face das alterações econômicas, em contraposição à antiga crença na capacidade de autoajuste do mercado ${ }^{20}$.

Keynes defendia a idéia dos orçamentos deficitários, a fim de que o Estado pudesse aplicar em investimentos públicos, gerando o pleno emprego e combatendo as crises cíclicas do capitalismo.

Nesse sentido, com a doutrina keynesiana e o reconhecimento da importância do gasto público no sistema econômico, o orçamento público "passou a ser sistematicamente utilizado como instrumento da política fiscal do governo, isto é, de sua ação que visava à estabilização ou à ampliação dos níveis da atividade econômica ${ }^{21}$ ".

Tal utilização das peças orçamentárias, por meio de uma política financeira de superávits e déficits com efeitos compensatórios, encontra-se na origem do chamado “orçamento cíclico". Segundo José Afonso da Silva,

A expressão orçamento cíclico é empregada para caracterizar a política financeira estimulada especialmente por John Maynard Keynes, visando à utilização dos meios orçamentários (receitas, despesas e técnicas) no sentido da manutenção do equilíbrio econômico durante as fases cíclicas. (...) A teoria do orçamento cíclico parte do fato histórico de que a economia de mercado se desenvolve por flutuações cíclicas mais ou menos regulares. Qualquer deles, porém, caracteriza-se por uma fase de grande expansão, seguida de outra de depressão da economia ${ }^{22}$.

Logo, com a intervenção do Estado na ordem econômica, passa o orçamento a apresentar novas funções, transmudando-se em "instrumento de programação econômica, de programação da ação governamental" e em "instrumento de política fiscal, quando

\footnotetext{
${ }^{19}$ TORRES, Ricardo Lobo, op. cit., p. 5.

${ }^{20}$ GIAMBIAGI, Fabio; ALÉM, Ana Cláudia. Finanças Públicas - Teoria e Prática no Brasil. $3^{\mathrm{a}}$ ed. São Paulo: Campus/Elsevier, 2008, p. 14.

${ }^{21}$ GIACOMONI, James. Orçamento Público. $14^{\mathrm{a}}$ ed. São Paulo: Atlas, 2007, p. 58.

${ }^{22}$ SILVA, José Afonso da, op. cit., p. 06/07.
} 
procura criar condições para o desenvolvimento nacional, estadual ou municipal, conforme se trate de orçamento federal, estadual ou municipal"23.

As consequuências da crescente intervenção do Estado na economia e os reflexos gerados nas instituições orçamentárias do século XX são apontados por Baleeiro, nos seguintes termos:

O profundo e crescente intervencionismo do Estado na economia, dirigindo-a e rechaçando os postulados clássicos e liberais, não poderia deixar de imprimir sua marca no orçamento.

De plano político de governo, em sentido restrito, ele se inclina a transformar-se, depois da Segunda Guerra, em alavanca do comando da conjuntura econômica. As idéias e práticas buscam empregar o orçamento como o aparelho para combater fases de depressão e de desemprego, promover investimentos, ou para conter as quadras inflacionárias. Os velhos princípios da técnica orçamentária, consagrados pelas gerações anteriores, vergam ao peso dessa tarefa enorme.

Os governos contemporâneos não se resignam a planejar apenas a administração. Querem planejar a economia e colocá-la como centro da política.

O orçamento já não é apenas político: tende a envolver toda a economia nacional, inclusive o setor privado ${ }^{24}$.

Assim sendo, os orçamentos públicos, para atender às múltiplas exigências e demandas que são formuladas nesse contexto histórico, sofrerão intensa influência das técnicas de administração, surgindo conceitos como Orçamento-programa, Orçamento de Desempenho - performance budget - e PPBS - planning programming and budgeting system -, que realçam, inequivocamente, suas novas funções ${ }^{25}$.

O Orçamento-programa seria uma espécie de síntese das variadas influências gerenciais que modificaram o orçamento público, sendo sua concepção básica extraída da experiência federal norte-americana obtida com a implantação do Orçamento de Desempenho ${ }^{26}$.

Giacomoni discrimina da seguinte forma os elementos que seriam essenciais ao Orçamento-programa:

a) os objetivos e propósitos perseguidos pela instituição e para cuja consecução são utilizados os recursos orçamentários;

b) os programas, isto é, os instrumentos de integração dos esforços governamentais no sentido da concretização dos objetivos;

c) os custos dos programas medidos por meio da identificação dos meios ou insumos (pessoal, material, equipamentos, serviços, etc) necessários para a obtenção dos resultados; e

\footnotetext{
${ }^{23}$ SILVA, José Afonso da, op. cit., p. 41.

${ }^{24}$ BALEEIRO, Aliomar, op. cit., p. 423.

${ }^{25}$ CONTI, José Mauricio. A autonomia financeira do Poder Judiciário. São Paulo: MP Editora, 2006, p. 58.

${ }^{26}$ GIACOMONI, James, op. cit., p.159.
} 
d) medidas de desempenho com a finalidade de medir as realizações (produto final) $\mathrm{e}$ os esforços despendidos na execução dos programas ${ }^{27}$.

Modernamente, portanto, o orçamento assume a função de elo entre o planejamento estatal e as atividades administrativas de gestão da coisa pública, tanto que a alocação dos recursos visa ao atingimento de objetivos e metas, ao contrário do orçamento tradicional em que a alocação de recursos visa à aquisição de meios.

A crise fiscal por que passa o Estado de Bem-Estar Social acarretará o debate quanto às funções que devem ser atribuídas ao Estado e implicará em novas perspectivas de reforma da engenharia estatal e de mudança do modelo burocrático de gestão pública. Dessa forma, com a crise do Welfare State, nas décadas de 1980 e 1990, modifica-se novamente o perfil da Constituição Orçamentária ${ }^{28}$.

Como bem ilustra Ricardo Lobo Torres:

No final da década de 1970, após as sucessivas crises do petróleo, o Estado de Bemestar Social passa a sofrer séria contestação, em virtude do crescimento insuportável da dívida pública, dos orçamentos repetidamente deficitários, da recessão econômica e do abuso na concessão de benefícios com os dinheiros públicos; a sua dimensão assistencialista conduz ao incremento das despesas com a previdência e a seguridade social sem a contrapartida da entrada de ingressos compatíveis com o volume dos encargos e, não raro, com o seu custeio pela incidência exageradamente progressiva dos impostos $^{29}$.

Em virtude das profundas modificações nas configurações históricas adotadas pelos Estados Nacionais, com claros reflexos nas instituições orçamentárias, ao longo da transformação do orçamento tradicional em direção ao orçamento moderno, houve uma mudança da função principal que se lhe atribuía: a de controle político no orçamento tradicional para a de instrumento de administração no orçamento moderno ${ }^{30}$.

A alteração de sua principal função, todavia, não implica em extinção da primeira função atribuída à peça orçamentária, antes, implica em uma cumulação de funções, responsável pelo caráter multifário e complexo dos orçamentos modernos. Nesse sentido, o orçamento apresenta-se como uma figura multifacetada, possuindo aspectos político, econômico, técnico e jurídico ${ }^{31}$. É exatamente a existência desses múltiplos contornos que complexifica o conhecimento integral do instituto.

${ }^{27}$ GIACOMONI, James, op. cit., p.155.

${ }^{28}$ TORRES, Ricardo Lobo, op. cit., p. 5.

${ }^{29}$ Ibid., p. 13.

${ }^{30}$ GIACOMONI, James. Orçamento Público. 13a ed. São Paulo: Atlas, 2005, p. 64/66.

${ }^{31}$ BALEEIRO, Aliomar. Uma Introdução à Ciência das Finanças. $15^{\mathrm{a}}$ ed. Rio de Janeiro: Forense, 1998, p.411/412. 
O desenvolvimento das instituições orçamentárias forjou, progressivamente, um novo elemento integrante da moderna concepção do Orçamento, qual seja, a de ser, também, um instrumento de administração. A nova configuração orçamentária será de fundamental importância para a análise da natureza jurídica da peça orçamentária, em função dos reflexos derivativos dessas transformações.

A interpretação jurídica dos contornos dos orçamentos públicos ainda sofreu, ao longo da história, intensa transformação, inclusive porque os ordenamentos jurídicos, ao serem modificados, passam a conferir distinta anatomia àqueles.

Analisando-se o aspecto jurídico e ciente de que o orçamento, nos Estados de Direito modernos, assume a roupagem de lei, surgirá o questionamento a respeito da natureza jurídica dessa lei e, consequentemente, dos seus efeitos jurídicos, discussão essa eternizada na doutrina.

\subsection{O Orçamento Público nas Constituiç̃̃es brasileiras}

Com a vinda da família real, iniciou-se um processo de organização das finanças brasileiras. A abertura dos portos trouxe a necessidade de maior disciplinamento na cobrança dos tributos aduaneiros. Além disso, em 1808, foram criados o Erário Público Tesouro - e o regime de contabilidade ${ }^{32}$.

A Constituição do Império de 1824 inicia o tratamento do orçamento público no Brasil. Atribui à Assembléia Geral a incumbência de fixação anual das despesas públicas (art. 15). Contudo, mais emblemático é o dispositivo que confere ao Ministro da Fazenda o dever de apresentar o Balanço Geral do Tesouro à Câmara dos Deputados, in verbis:

Art. 172. O Ministro de Estado da Fazenda, havendo recebido dos outros Ministros os orçamentos relativos ás despezas das suas Repartições, apresentará na Camara dos Deputados annualmente, logo que esta estiver reunida, um Balanço geral da receita e despeza do Thesouro Nacional do anno antecedente, e igualmente o orçamento geral de todas as despezas publicas do anno futuro, e da importancia de todas as contribuições, e rendas publicas.

\footnotetext{
${ }^{32}$ GIACOMONI, James, op. cit., p. 52.
} 
Segundo Baleeiro, o primeiro orçamento nacional elaborado em conformidade com esse dispositivo foi o votado para o exercício 1831-1832. Nada obstante, desde 1828, havia o orçamento do Tesouro na Corte e Província do Rio de Janeiro ${ }^{33}$.

A Constituição da República dos Estados Unidos do Brasil de 1891 já apresenta um maior detalhamento das questões orçamentárias, embora dispersas no texto constitucional. A principal alteração, todavia, é a competência privativa atribuída ao Congresso Nacional para a elaboração da peça orçamentária:

Art. 34 - Compete privativamente ao Congresso Nacional:

$1^{\circ}$ ) orçar a receita, fixar a despesa federal anualmente e tomar as contas da receita e despesa de cada exercício financeiro;

(...)

No entanto, Arizio de Viana ressalta que, embora a elaboração do orçamento tenha passado a ser competência privativa do Congresso Nacional, na prática a iniciativa sempre partiu do gabinete do Ministro da Fazenda, que orientava informalmente a comissão parlamentar de finanças ${ }^{34}$.

Além disso, o texto constitucional do Império insere como crime de responsabilidade do Presidente a violação à lei orçamentária (art. 54, $8^{\circ}$ ), além de instituir um Tribunal de Contas para liquidar as contas da receita e despesa (art. 89).

A disputa política do orçamento, que envolve a dinâmica e o relacionamento entre os Poderes de Estado, sempre esteve presente na evolução histórica da instituição orçamentária brasileira. Sustenta Ricardo Lobo Torres que:

No Brasil a questão política se move pendularmente em todo o período republicano, caminhando de períodos de centralismo e preponderância do Executivo para os de descentralização e assunção de maiores responsabilidades pelo Congresso. Nas épocas de autoritarismo (1930-1945 e 1964-1979) concentram-se no Executivo as decisões orçamentárias básicas. Na redemocratização cresce o papel do Legislativo (1891, 1946 e $1988)^{35}$.

Sobre isso, a ascensão de Vargas e o período que se inicia na década de 1930 trouxeram significativas alterações no panorama anterior. A década é inaugurada com a Revolução de 30, liderada por Getúlio, em oposição ao domínio da oligarquia paulista,

\footnotetext{
${ }^{33}$ BALEEIRO, Aliomar. Uma Introdução à Ciência das Finanças. Atualizador Dejalma de Campos. $16^{\mathrm{a}}$ ed. Rio de Janeiro: Forense, 2006, p. 417.

${ }^{34}$ VIANA, Arizio de. Orçamento Brasileiro. $2^{\mathrm{a}}$ ed. Rio de Janeiro: Financeiras, 1950, p.76.

${ }^{35}$ TORRES, Ricardo Lobo, op. cit., p. 52.
} 
tendo o desenvolvimento econômico como peça fundamental das alianças estabelecidas ${ }^{36}$, além da importância que se atribuiu à modernização do aparelho de Estado brasileiro.

A Constituição de 1934 faz parte desse novo contexto histórico-político brasileiro: novamente remete ao Ministro da Fazenda a competência de elaboração da peça orçamentária (art. 60, parágrafo único); comete ao Poder Legislativo a atribuição de votação da lei orçamentária (art. 39, 2); introduz toda uma seção para tratamento da questão orçamentária (Seção IV do Capítulo II), e, também, trata da ordem econômica e social no Título IV.

A prática abusiva das chamadas caudas orçamentárias, ou seja, dispositivos de lei sobre os mais variados assuntos estranhos às finanças públicas inseridos nas peças orçamentárias, que proliferara sobretudo durante a Primeira República ${ }^{37}$, foi objeto de vedação no novo texto constitucional:

Art. 50

(...)

$\S 3^{\circ}$ - A lei de orçamento não conterá dispositivo estranho à receita prevista e à despesa fixada para os serviços anteriormente criados. Não se incluem nesta proibição:

a) a autorização para abertura de créditos suplementares e operações de créditos por antecipação de receita;

b) a aplicação de saldo, ou o modo de cobrir o déficit.

De outro lado, o $\$ 5^{\circ}$ do art. 50 da Carta de 1934 procurava solucionar a intrigante questão do não encaminhamento da peça orçamentária pelo Legislativo, para sanção pelo Poder Executivo, considerando prorrogado o orçamento então vigente: "§ $5^{\circ}$ - Será prorrogado o orçamento vigente se, até 3 de novembro, o vindouro não houver sido enviado ao Presidente da República para a sanção."

Com o estabelecimento do regime autoritário representado pelo Estado Novo, veio à lume nova Constituição, decretada em 10 de novembro de 1937.

$\mathrm{O}$ art. 67 da nova Carta Constitucional estabelece, junto à Presidência da República, um Departamento Administrativo com a competência de organizar e racionalizar a elaboração da peça orçamentária, além de fiscalizar a execução do orçamento aprovado. O princípio da unicidade da lei orçamentária é mantido no art. 68; por sua vez, consta do art. 70 a restrição às caudas orçamentárias.

\footnotetext{
${ }^{36}$ GREMAUD, Amaury Patrick; VASCONCELlOS, Marco Antonio Sandoval de; TONETO JÚNIOR, Rudinei. Economia Brasileira Contemporânea. $7^{\text {a }}$ Ed. São Paulo: Atlas, 2007, p. 352/353.

${ }^{37}$ BALEEIRO, Aliomar. Uma Introdução à Ciência das Finanças. Atualizador Dejalma de Campos. $16^{\mathrm{a}} \mathrm{ed}$. Rio de Janeiro: Forense, 2006, p. 442.
} 
Em relação ao art. 71, há a fixação do prazo de 45 dias para a votação do orçamento pela Câmara dos Deputados, tendo sido retirado do texto constitucional o instituto da prorrogação automática do orçamento no caso do não encaminhamento da peça pelo Congresso ao Presidente.

Contudo, uma vez que as duas Câmaras Legislativas previstas no texto, isto é, Câmara dos Deputados e Conselho Federal, nunca foram instaladas, o orçamento federal foi sempre elaborado e decretado pelo chefe do Executivo ${ }^{38}$.

Destaque-se que o dispositivo que previa a hipótese de crime de responsabilidade do Presidente no caso de violação à lei orçamentária, presente nas Constituições brasileiras de 1891 e 1934, foi retirado da ordem constitucional de 1937.

A redemocratização do País veio com a Constituição de 1946, que previa novamente a elaboração do projeto da lei orçamentária pelo Executivo e sua discussão e votação pelas Casas Legislativas. Os dispositivos constitucionais sobre a matéria consagraram princípios orçamentários tradicionais como o da unidade (art. 73, caput), universalidade (art. 73, caput), exclusividade (art. 73, $\S 1^{\circ}$ ) e especialização (art. 73, $\S 2^{\circ}$ ), além de evidenciar o papel da Corte de Contas ${ }^{39}$.

Já o art. 74 do texto previu novamente o fenômeno da prorrogação do orçamento vigente no caso do não encaminhamento da nova lei orçamentária pelo Legislativo, até 30 de novembro, para sanção pelo Presidente.

A Constituição de 1967, elaborada no período da ditadura militar iniciada em 1964, foi a que, de forma mais detalhada, deu corpo e relevo ao regramento das instituições orçamentárias. Tratou do orçamento em toda a Seção VI do Capítulo VI, dedicado ao Poder Legislativo, estendendo-se ao longo de oito artigos, do art. 63 ao art. 70, e vários parágrafos, incisos e alíneas.

A competência da iniciativa das leis orçamentárias foi reservada ao Presidente da República (art. 67). O $\S 1^{\circ}$ do art. 67, por sua vez, tratou de vedar a deliberação de emendas que causassem aumento da despesa global ou de cada órgão, projeto ou programa, ou, ainda, as que visassem a modificar o seu montante, natureza e objetivo. Tal dispositivo retirava prerrogativas do Poder Legislativo quanto à matéria orçamentária, restringindo-lhe a atuação.

Além disso, o art. 60 atribuiu competência exclusiva ao Chefe do Executivo para a iniciativa de leis que dispusessem sobre matéria financeira (art. 60, I) e aumentassem

\footnotetext{
${ }^{38}$ GIACOMONI, James, op. cit., p. 55.

${ }^{39}$ Ibid., p. 55.
} 
vencimentos ou a despesa pública (art. 60, II). O parágrafo único do art. 60 ainda tratou de vedar emendas que aumentassem a despesa prevista em projetos de competência exclusiva do Presidente da República.

Como salienta Giacomoni, "o papel desse Poder passou a ser o de aprovar o projeto de lei oriundo do Executivo, já que a hipótese de rejeição era impossível de ser considerada, pois o governo não teria como iniciar seu exercício financeiro (...), ${ }^{, 40}$.

Considerando-se, ainda, o art. 68 que fixava um prazo de quatro meses, a contar de seu recebimento, para que o Poder Legislativo devolvesse o projeto de lei orçamentária para sanção, pois, caso contrário, seria promulgado como lei, tem-se, claramente delineado, o processo altamente centralizador das decisões orçamentárias no Poder Executivo.

Por meio do $\S 3^{\circ}$ do art. 65 foi inserido no texto constitucional o princípio da não vinculação da receita de tributos a órgão, fundo ou despesa. Outra inovação do texto refere-se à previsão do orçamento plurianual de investimento (art. 63, parágrafo único e art. $65, \S 4^{\circ}$ ), ao qual ficavam submetidas as despesas de capital e os projetos e programas que se prolongassem para mais de um exercício financeiro. Houve, ainda, a previsão de dotações plurianuais para a execução de planos de valorização das regiões menos desenvolvidas no País (art. 65, $\S 6^{\circ}$ ).

Interessante dispositivo foi inserido para permitir que, no caso de execução de política corretiva de recessão econômica, o montante da despesa autorizada fosse superior ao total das receitas estimadas para o mesmo período (art. $66, \S 1^{\circ}$, 'a'), nos limites e prazos fixados pelo Senado Federal.

A fiscalização financeira e orçamentária foi objeto de tratamento em Seção própria (Seção VII), e atribuída ao Congresso Nacional, por meio de controle externo, com o auxílio do Tribunal de Contas, bem como aos sistemas de controle interno do Poder Executivo (art. 71).

$\mathrm{O}$ art. 72 atribui ao Poder Executivo a manutenção do sistema de controle interno, visando criar condições para eficácia do controle externo (inciso I), acompanhar a execução de programas de trabalho e do orçamento (inciso II) e avaliar os resultados alcançados pelos administradores (inciso III).

Durante o processo de redemocratização brasileira, foi convocada uma Assembléia Nacional Constituinte, encarregada da elaboração de uma nova Constituição. Em 5 de

\footnotetext{
${ }^{40}$ GIACOMONI, James, op. cit., p. 56.
} 
outubro de 1988, como resultado desse processo, foi promulgada a Constituição de 1988, chamada de Constituição Cidadã.

Dada a extrema relevância da nova ordem constitucional inaugurada em 1988 e em função dos seus reflexos sobre o regramento das leis orçamentárias em nosso ordenamento jurídico, os dispositivos da Carta de 1988 serão objeto de exame particularizado, exame esse feito na próxima seção deste trabalho.

\subsubsection{A concepção orçamentária da Constituição de 1988}

Com a promulgação da Constituição Federal de 1988, as leis orçamentárias são alçadas à mais elevada significação. Não por outro motivo, o legislador constituinte reservou a elas extenso e minucioso tratamento ao longo de toda a Seção II (Dos Orçamentos) do Capítulo II (Das Finanças Públicas) do Título VI (Da Tributação e do Orçamento).

Tal inserção topográfica, contudo, não esgota as normas relativas à matéria, visto que há outros dispositivos que as regulamentam, seja no Ato das Disposições Constitucionais Transitórias (ADCT), seja nos arts. 70 a 74 da CF/88, bem como em outros dispositivos esparsos.

Não obstante tais leis tenham recebido um tratamento diferenciado, não conferido a nenhuma outra espécie legislativa, o art. $166, \S 7^{\circ}$, do texto constitucional, indicou expressamente que "aplicam-se aos projetos mencionados neste artigo, no que não contrariar o disposto nesta seção, as demais normas relativas ao processo legislativo".

Frise-se, portanto, que, apesar de permeado de peculiaridades, o processo legislativo orçamentário guarda absoluta sincronia com o procedimento normal de feitura das leis, no que a Constituição não dispuser diferentemente.

As especificidades que lhes dão contornos próprios e peculiares são as seguintes:

$1^{\text {a }}$. Iniciativa reservada do Chefe do Poder Executivo (art. 165, incisos I, II e III, da $\mathrm{CF} / 88)$;

$2^{\text {a }}$. Os atos do Presidente da República que atentem contra a lei orçamentária caracterizam crime de responsabilidade (art. 85, VI, da CF/88); 
$3^{\mathrm{a}}$. A lei orçamentária anual não pode conter dispositivo estranho à previsão da receita e à fixação da despesa, salvo a autorização para abertura de créditos suplementares e contratação de operações de crédito (art. 165 , § $8^{\circ}$, da CF/88);

$4^{\mathrm{a}}$. Há prazos para o encaminhamento das leis orçamentárias ao Congresso Nacional (art. 35, § $2^{\circ}$, do ADCT)

5a. Há restrições constitucionais materiais para a aceitação de emendas parlamentares (art. 166, § $3^{\circ}$, II e III, da CF/88)

$6^{\text {a }}$. Deve haver compatibilidade entre os textos dos projetos da LOA, LDO e PPA para aprovação de emendas parlamentares (art. 166, $\S 3^{\circ}$, I , e $\S 4^{\circ}$, da CF/88).

$7^{\mathrm{a}}$. Possuem tramitação própria perante a Comissão Mista de Planos, Orçamentos Públicos e Fiscalização (art. 166, $\S 1^{\circ}$, da CF/88);

$8^{a}$. É vedada a utilização de medidas provisórias sobre matéria orçamentária, com exceção dos créditos extraordinários (art. 62, § 1, I, “d”, da CF/88);

$9^{a}$. É vedada a utilização de leis delegadas sobre planos plurianuais, diretrizes orçamentárias e orçamentos (art. $68, \S 1^{\circ}$, III, da CF/88);

$10^{\mathrm{a}}$. A falta de aprovação do projeto de lei de diretrizes orçamentárias impede a interrupção da sessão legislativa (art. 57, § $2^{\circ}$, da CF/88);

11 a . São objeto de fiscalização pelo Controle Externo, a cargo do Poder Legislativo, com o auxílio do Tribunal de Contas (art. 70, caput, c.c. art. 71, da CF/88);

$12^{\mathrm{a}}$. São objeto de avaliação e fiscalização por parte do sistema de controle interno integrado dos Poderes Legislativo, Executivo e Judiciário (art. 74, I, II e III, da CF/88).

Por outro lado, não há, no aspecto formal, distinção das leis orçamentárias das demais leis. Fazem parte do processo legislativo ordinário, previsto no art. 59, III, da Constituição da República; são objeto de discussão no Congresso Nacional; recebem emendas, ou não, sendo aprovadas de acordo com o quórum simples correspondente às leis ordinárias; o autógrafo é encaminhado ao Presidente da República para sanção, ou veto, e posterior publicação; também recebem, como qualquer lei ordinária, um número de identificação, de acordo com a sequência correspondente.

$\mathrm{O}$ art. 165 do texto constitucional prevê as três leis orçamentárias: Plano Plurianual - PPA; Lei de Diretrizes Orçamentárias - LDO e Lei Orçamentária Anual - LOA, e indica, expressamente, as matérias que devem ser objeto de tratamento por cada uma delas.

Sobreleva ressaltar a íntima organicidade e compatibilidade que devem permear a feitura e coexistência dessas leis. Previstas conjuntamente e de forma encadeada no caput 
do art. 165 do texto constitucional pátrio, alçam-se à categoria das mais relevantes leis infraconstitucionais em nosso ordenamento $^{41}$ ao imprimirem condução e direção articuladas ao funcionamento da máquina administrativa e do Governo.

Não por outro motivo, o $\S 7^{\circ}$ do referido art. 165 prevê que os orçamentos fiscal e de investimento das empresas, os quais compõem, conjuntamente com o orçamento da seguridade social, a lei orçamentária anual, deverão encontrar-se "compatibilizados com o plano plurianual".

Seguem a mesma lógica os dispositivos previstos no art. 166 , $\S 3^{\circ}$ e $4^{\circ}$, que impõem, como pré-requisito para aprovação de emendas parlamentares, a existência de compatibilidade entre o PPA, LDO e LOA.

Essa sistemática constitucional revela a necessidade de uma coerência interna entre as citadas leis orçamentárias, que se expressa por meio da compatibilidade dos referidos diplomas legais.

Dessa forma, muito embora o PPA, a LDO e a LOA sejam, formalmente, três leis ordinárias distintas, tais estatutos guardam lógica e encadeamento normativo próprios, que se revelam não somente pela sintonia que deve existir entre eles, como também pela irradiação jurídica dos planos mais gerais, ou de longo prazo, sobre aqueles operacionais, ou de curto prazo.

Nesse diapasão, a doutrina defende que:

a Constituição Federal de 1988 institucionalizou um verdadeiro sistema orçamentário ao prever a edição de uma lei do plano plurianual, lei de diretrizes orçamentárias e lei do orçamento anual, todas atos normativos que, de forma hierarquizada, se interligam com o objetivo de dotar o setor público de um processo de planejamento orçamentário que espelhe um plano de governo a longo, médio e curto prazos (arts. 165 e 166) ${ }^{42}$.

De forma assemelhada, Ives Gandra da Silva Martins e Celso Bastos seguem essa linha de raciocínio:

(...) o plano plurianual estabelece as regras fundamentais de todo o projeto econômico financeiro do governo, as diretrizes orçamentárias indicam - para o mesmo período - as regras que norteiam a preparação dos orçamentos, e estes, a projeção anual de gastos e

${ }^{41}$ BRITTO, Carlos Ayres. O Regime Constitucional dos Tribunais de Contas. In: O Novo Tribunal de Contas. SOUSA, Alfredo José; FRANCO, António de Sousa; BRITTO, Carlos Ayres et al. $3^{\mathrm{a}}$ ed., rev. atual. Belo Horizonte: Fórum, 2005, p. 64.

${ }^{42}$ MEIRELLES, Hely Lopes. Direito Municipal Brasileiro. Atual. por Márcio Schneider Reis e Edgard Neves da Silva. 14ª ed. São Paulo: Malheiros, 2006, p. 266. 
despesas públicas, neles incluídos o crédito público, segue uma concepção moderna do papel do Estado em sua inserção na vida societária ${ }^{43}$.

E observam, em outro trecho, que:

Em outras palavras, o plano plurianual a que faz menção o legislador não cuida somente de meras sugestões desenvolvimentistas, mas impõe ao Poder Público limites a sua ação intervencionista e parâmetros à programação que implique despesas e receitas, vinculadas a mais de um exercício. Por essa razão, tais planos, por serem mais amplos, prevalecem sobre as leis orçamentárias anuais naquilo em que cuidar da mesma matéria, sendo a ordem de indicação do art. 165 preferencial. Vale dizer, a sociedade, a partir do plano plurianual, sabe o comportamento que espera do governo no concernente aos projetos de longo alcance, sendo os orçamentos mero reflexo daquela parte do planejamento que se esgota no exercício ${ }^{44}$.

Ao lado da coerência interna entre os três estatutos orçamentários, deve existir, também, o que se pode chamar de coerência externa, a normatizar a relação existente entre o plano plurianual e os planos e programas nacionais, regionais e setoriais previstos no texto constitucional. Nesse sentido, o $\S 4^{\circ}$ do art. 165 prescreve que "os planos $e$ programas nacionais, regionais e setoriais previstos nesta Constituição serão elaborados em consonância com o plano plurianual e apreciados pelo Congresso Nacional".

Como ressalta José Afonso da Silva, ao analisar a sistemática orçamentária prevista na Constituição, essa integração entre os planos e programas

é que dá configuração à concepção de orçamento-programa, não se tratando de simples justaposição de planos, mas de uma vinculação permanente e contínua, que não admite interrupção, de sorte que os planos mais gerais ou globais abrangem os mais concretos e a execução destes leva à materialização daqueles ${ }^{45}$.

Dessa forma, pode-se sustentar que a Constituição Federal prevê uma conexão lógica, sistemática e orgânica entre PPA, LDO e LOA.

Consoante a determinação constitucional, os objetivos, diretrizes e metas governamentais integram, obrigatoriamente, o conteúdo das peças orçamentárias. Esse o sentido do comando previsto no art. $165, \S 1^{\circ}$, da Carta de 1988 , que realça que o PPA deverá estabelecer "diretrizes, objetivos e metas para a administração pública federal". $\mathrm{Na}$ mesma linha, o conteúdo da LDO deverá prever, obrigatoriamente, "metas e prioridades" da administração pública federal (art. 165, § 2º CF/88).

${ }^{43}$ BASTOS, Celso Ribeiro; MARTINS, Ives Gandra da Silva. Comentários à Constituição do Brasil. $2^{\mathrm{a}}$ ed. São Paulo: Saraiva, 2001, v. 6, t. II, p. 207.

${ }^{44}$ Ibid., p. 204.

45 SILVA, José Afonso da. Curso de Direito Constitucional Positivo. 26 a ed., rev. e atual. São Paulo: Malheiros, 2006, p. 737. 
Uma análise sistemática do texto constitucional deriva o mesmo conteúdo obrigatório para a LOA. Deverá haver, no curto prazo, fixação de objetivos que estejam relacionados com as estratégias e metas de médio prazo fixadas pelo PPA e LDO e que visem concretizá-las.

Por outro lado, deve-se ressaltar que os dispositivos previstos na Seção IX - Da fiscalização Contábil, Financeira e Orçamentária oferecem uma série de elementos integrantes da concepção orçamentária prevista no corpo da Constituição de 1988 e servem de complemento sistemático a diversos dispositivos constantes da Seção II - Dos Orçamentos, embora cada seção integre um Título próprio na sistemática constitucional (Título IV - Da Organização dos Poderes e Título VI - Da Tributação e do Orçamento).

Nesse aspecto, a Constituição prevê a necessidade de avaliação dos resultados, quanto à eficiência e eficácia, da gestão orçamentária, conforme aponta o art. 74, incisos I e II, impregnando o sentido do texto constitucional de uma moderna concepção gerencial ${ }^{46}$.

Além disso, o caput do art. 70 da Carta de 1988 faz expressa referência ao princípio da economicidade. Tal princípio, orientador da fiscalização orçamentária, irradia sua projeção por sobre o conteúdo das leis orçamentárias, que devem passar a incorporar critérios e/ou mensurações dos custos dos programas previstos no instrumental orçamentário.

O princípio da economicidade, como anota Mileski, "advém de um princípio tipicamente técnico-econômico, envolvendo os custos relativos aos objetivos que se pretende alcançar" ${ }^{, 47}$. Consubstancia-se, segundo Ricardo Lobo Torres, na minimização de custos e gastos públicos e na maximização da receita e da arrecadação ${ }^{48}$.

A Constituição de 1988 reservou às leis orçamentárias conteúdo material determinado, estipulando expressamente seus elementos integrantes. Incluiu, nesse sentido, dispositivo expresso que veda matéria estranha à previsão da receita e fixação da despesa na lei orçamentária anual, salvo as duas exceções ali consignadas (art. 165, § $8^{\circ}$, da CF/88).

Contudo, há que se atentar para o fato de que tal vedação deve ser lida em consonância às demais disposições constitucionais. Na lição de José Afonso da Silva,

\footnotetext{
${ }^{46}$ Art. $74 \mathrm{CF} / 88$. Os Poderes Legislativo, Executivo e Judiciário manterão, de forma integrada, sistema de controle interno com a finalidade de: I - avaliar o cumprimento das metas previstas no plano plurianual, a execução dos programas de governo e dos orçamentos da União; II - comprovar a legalidade e avaliar os resultados, quanto à eficácia e eficiência, da gestão orçamentária, financeira e patrimonial nos órgãos e entidades da administração federal, bem como da aplicação de recursos públicos por entidades de direito privado; (grifos nossos).

${ }^{47}$ MILESKI, Helio Saul. O Controle da Gestão Pública. São Paulo: Revista dos Tribunais, 2003, p. 250.

${ }^{48}$ TORRES, Ricardo Lobo, op. cit., p. 210.
} 
a lei de orçamento deverá conter somente matéria referente à fixação da despesa e previsão da receita, mas não se deve dar interpretação acanhada ao texto e hoje deve receber compreensão adequada em face da nova sistemática orçamentária, pois (...) o orçamento-programa não se realiza com um conteúdo tão estreito. Se outras normas constitucionais fundamentam a adoção desse tipo de orçamento, claro está que o princípio da exclusividade não se resume ao sentido literal do texto ${ }^{49}$.

Efetivamente, o objetivo do Constituinte, nessa questão, foi o de vedar o fenômeno das "caudas orçamentárias". Por meio de tal expediente, buscava-se forçar a aprovação de matérias outras, estranhas ao orçamento, que eram inseridas no respectivo projeto de lei. Conforme acentua Baleeiro, o costume teria chegado às "raias do escândalo" quando houve o veto à lei orçamentária de 1922 pelo presidente Epitácio Pessoa, na qual teriam constado, inclusive, nomeações e promoções de funcionários públicos ${ }^{50}$.

Destarte, a Carta Política de 1988 ao indicar o conteúdo constitucional das leis orçamentárias, desenhou um perfil conceitual muito assemelhado àquele do Orçamento de Desempenho - performance-based budget - ou Orçamento por Resultados, por meio da necessidade de previsão dos objetivos, programas, custos e indicadores de desempenho nos estatutos orçamentários, verificando-se, ademais, que princípios como o da eficiência e da economicidade orientam a elaboração, execução, monitoramento e controle das leis orçamentárias no modelamento adotado pelo texto constitucional brasileiro.

\subsection{Orçamento como instrumento gerencial}

Com Getúlio Vargas, a Revolução de 1930 instaurou um período de state building, caracterizado pela centralização política e administrativa, bem como pela intervenção na economia. Três novas gramáticas passaram a pautar as relações entre Estado e sociedade: corporativismo, insulamento burocrático e universalismo de procedimentos. Porém, as gramáticas modernizantes interagiram com arranjos clientelistas previamente dominantes ${ }^{51}$.

Buscou-se o universalismo de procedimentos por meio da reforma do serviço público e do estabelecimento do sistema de mérito, sob a supervisão do Departamento de

${ }^{49}$ SILVA, José Afonso da. Orçamento-Programa no Brasil. São Paulo: Revista dos Tribunais, 1973, p. $107 / 108$.

${ }^{50}$ BALEEIRO, Aliomar, op. cit., p. 442/443.

51 NUNES, Edson. A Gramática Política do Brasil. Brasília: ENAP - Escola Nacional de Administração Pública, 1997, p. 47. 
Administração do Serviço Público - DASP ${ }^{52}$. Por sua vez, conseguiu-se o insulamento burocrático com as recém-criadas autarquias, com as atividades desse Departamento e, mais tarde, com a criação de empresas estatais ${ }^{53}$.

A reforma burocrática de 1936 é reconhecida como a primeira reforma administrativa no Brasil, baseando-se no princípio do mérito profissional e na descrição de burocracia feita por Max Weber. Nas palavras de Bresser, “A administração pública burocrática é aquela baseada em um serviço civil profissional, na dominação racional-legal weberiana e no universalismo de procedimentos, expresso em normas rígidas de procedimento administrativo., ${ }^{, 4}$

A criação do Dasp representou a afirmação dos princípios centralizadores e hierárquicos da burocracia clássica, necessária para que se desenvolvesse a separação entre o público e o privado, entre o político e o administrador público. Tal modelo foi adotado em substituição à administração patrimonialista, em que o nepotismo e o empreguismo eram a regra ${ }^{55}$.

As principais áreas em que se concentrou a reforma administrativa de 1936 foram a administração de pessoal - com o sistema de mérito -, o orçamento e a administração orçamentária - tendo o orçamento como um plano de administração -, a administração de material e a revisão de estruturas e racionalização de métodos ${ }^{56}$.

Ao final do governo Vargas, em 1945, o país estava bastante diferente em comparação à República Velha, com um aparelho de Estado complexo e centralizado, meios tecnocráticos de controle e regulamentos corporativos ${ }^{57}$.

Todavia, o paradigma burocrático logo deu mostras de esgotamento, em função das distorções e desvios decorrentes de sua extrema rigidez. De acordo com Bresser:

A administração pública burocrática clássica foi adotada porque era uma alternativa muito superior à administração patrimonialista do Estado. Entretanto, o pressuposto de eficiência em que se baseava não se mostrou real. No momento em que o pequeno Estado liberal do século XIX cedeu definitivamente lugar ao grande Estado social e econômico do século XX, verificou-se que ela não garantia nem rapidez, nem boa qualidade, nem custo baixo para os serviços prestados ao público. Na verdade, a

\footnotetext{
52 NUNES, Edson, op. cit., p. 49.

${ }^{53}$ Ibid., p. 50.

54 BRESSER PEREIRA, Luiz Carlos. Reforma do Estado para a Cidadania. Brasília: ENAP - Escola Nacional de Administração Pública, 1998, p. 20.

55 BRESSER PEREIRA, Luiz Carlos. Da administração pública burocrática à gerencial. In: Reforma do Estado e Administração Pública Gerencial. BRESSER PEREIRA, Luiz Carlos; SPINK, Peter. (orgs.). $6^{\mathrm{a}}$ ed. Rio de Janeiro: Editora FGV, 2005, p. 241.

56 BRESSER PEREIRA, Luiz Carlos. Reforma do Estado para a Cidadania. Brasília: ENAP - Escola Nacional de Administração Pública, 1998, p. 165.

${ }^{57}$ NUNES, Edson, op. cit., p. 57.
} 
administração burocrática é lenta, cara, auto-referida, pouco ou nada orientada para o atendimento das demandas dos cidadãos ${ }^{58}$.

Em 1967, durante o período de ditadura militar, teve início a segunda reforma administrativa brasileira, consubstanciada no Decreto-lei $n^{\circ}$ 200/67. Os princípios orientadores desse novo ensaio reformador foram o planejamento, a coordenação, a descentralização, a delegação de competência e o controle, nos termos do art. $6^{\circ}$ do referido diploma legal.

A nova reforma foi uma tentativa de superação da rigidez burocrática, com ênfase na descentralização, mediante a outorga de autonomia às entidades da administração indireta. Nesse sentido, pode ser considerada como um primeiro momento da administração gerencial no Brasil ${ }^{59}$.

Duas consequências indesejadas, porém, terminaram por levar ao fracasso a reforma administrativa embutida no Decreto-lei 200/67: em primeiro lugar, ensejou a sobrevivência de práticas patrimonialistas ao permitir a contratação de empregados sem concurso público; e, em segundo, levou ao enfraquecimento do núcleo estratégico do Estado, dada a visão pejorativa da administração direta como burocrática e enrijecida, impedindo sua mudança e fortalecimento ${ }^{60}$.

O restabelecimento democrático e a promulgação da nova ordem constitucional em 1988 representariam uma tentativa de reversão desse quadro. Assim, a Constituição de 1988 conferiria primazia ao modelo burocrático que não chegara a se completar no país, por meio de uma priorização da administração direta, com vistas a um modelo centralizado, hierárquico e rígido ${ }^{61}$. Foi adotado, por exemplo, o regime jurídico único para todo o funcionalismo, de forma indistinta. Além disso, eliminou-se a autonomia de autarquias e fundações ao serem extendidas as novas regras a toda a administração pública $^{62}$.

Paralelamente ao período de restabelecimento democrático brasileiro, inicia-se, nos países centrais, um processo de modificação do perfil da administração pública, rumo ao

\footnotetext{
58 BRESSER PEREIRA, Luiz Carlos. Da administração pública burocrática à gerencial. In: Reforma do Estado e Administração Pública Gerencial. BRESSER PEREIRA, Luiz Carlos; SPINK, Peter. (orgs.). $6^{\mathrm{a}}$ ed. Rio de Janeiro: Editora FGV, 2005, p. 241.

${ }^{59}$ Ibid., p. 244.

${ }^{60}$ Ibid., p. 244.

${ }^{61}$ Ibid., p. 246.

${ }^{62}$ Ibid., p. 247.
} 
que pode ser chamado de "administração pública gerencial"63. Como destacam Pollitt e Bouckaert:

\begin{abstract}
Em geral, as reformas gerenciais apresentaram um volume e variedade realmente grandes. É bastante provável que o processo de reforma tenha se intensificado após 1985, e que os contatos internacionais tenham desempenhado um papel importante no 'mercado' global de determinados tipos de reforma ${ }^{64}$.
\end{abstract}

A administração pública gerencial também pode ser chamada de "nova gestão pública" - New Public Management $-{ }^{65}$. A New Public Management utiliza como critérios de sua retórica a economia - sintetizada na redução nos insumos -, a eficiência consistente na razão insumo/produto - e a eficácia - que se traduz na razão objetivos/resultados ${ }^{66}$. Pollitt e Bouckaert ainda afirmam que "Em teoria, a NPM está totalmente ligada à melhoria do desempenho - fazer os governos mais conscientes em relação a custos, eficientes, eficazes, compreensivos, voltados à satisfação do cliente, flexíveis e transparentes.",67

Para Bresser, o novo modelo gerencialista possui como características:

administração profissional, indicadores de desempenho explícitos, maior ênfase no controle de resultados, divisão das organizações públicas em unidades menores, maior competição entre as unidades, ênfase no uso de práticas de gestão originadas no setor privado, e ênfase em maior disciplina e parcimônia no uso de recursos ${ }^{68}$.

A Constituição de 1988 representou a síntese de movimentos antagônicos, e, dessa forma, ao lado de instituições burocráticas, previu em seu corpo uma série de princípios e dispositivos que estão diretamente ligados a um perfil gerencialista de gestão pública, como medida de eficiência e eficácia da Administração Pública.

Mesmo os estudiosos da administração pública destacam a conflituosidade presente no texto constitucional, como se percebe da análise de Bresser:

\footnotetext{
${ }^{63}$ Ibid., p. 242.

${ }^{64}$ POLLITT, Christopher; BOUCKAERT, Geert. Avaliando reformas da gestão pública: uma perspectiva internacional. Revista do Serviço Público. ENAP - Escola Nacional de Administração Pública, Brasília, ano 53, n. 3, p. 17, jul-set. 2000.

${ }^{65}$ BRESSER PEREIRA, Luiz Carlos. Reforma do Estado para a Cidadania. Brasília: ENAP - Escola Nacional de Administração Pública, 1998, p. 20.

${ }^{66}$ POLLITT, Christopher; BOUCKAERT, Geert, op. cit., p. 12/14.

${ }^{67}$ Ibid., p. 24.

${ }^{68}$ BRESSER PEREIRA, Luiz Carlos, op. cit., p. 110.
} 
As novas instituições normativas já estavam contraditoriamente presentes na Constituição de 1988, a qual, embora marcada pelo centralismo do regime jurídico burocrático único, já previa a transferência de recursos paras os estados e municípios e a correspondente descentralização das ações sociais do Estado (... $)^{69}$.

Por meio de diversos dispositivos constitucionais previa-se, por exemplo, a análise e o controle de resultados, inclusive relativamente aos orçamentos públicos, além de critérios como eficiência e eficácia e de princípios como o da economicidade (arts. 70, caput, 74, I e II, CF/88).

Portanto, a Constituição contemplava contornos gerenciais de administração pública - e.g. avaliação do cumprimento das metas orçamentárias por meio de um controle a posteriori; avaliação dos resultados da gestão quanto à eficiência e eficácia -, paralelamente a um controle hierárquico e rígido, passo a passo, dos processos administrativos, de corte burocrático clássico ${ }^{70}$.

No que se refere aos diferentes delineamentos dos controles nos modelos burocrático e gerencial, é elucidativa a análise feita por Bresser:

No caso da administração pública gerencial, os controles pari passu de procedimentos e o sistema de check and balances continuam a ser utilizados, mas perdem importância relativa. No plano ainda hierárquico, são crescentemente substituídos pelo controle $a$ posteriori de resultados previamente contratados; no plano dos quase-mercados, pela competição administrada entre entidades às quais foi garantida autonomia gerencial; e no nível político, pelos controles democráticos: a transparência dos atos públicos, os controles realizados por organizações e conselhos públicos não-estatais ou do terceiro setor, e o controle da imprensa e da oposição. Os controles sociais são essenciais na administração pública gerencial na medida em que compensam a redução do controle legal de procedimentos e complementam o controle de resultados. Este, por sua vez, na medida em que define com mais precisão os indicadores de desempenho da organização, facilita o próprio controle democrático exercido pelos cidadãos ${ }^{71}$.

A lógica da chamada "Reforma do Estado", entre 1995 e 2002, se dá em termos de eficiência e resultados, transplantando mecanismos da iniciativa privada para a Administração Pública e pautando a atuação do Estado pelo mercado ${ }^{72}$. De acordo com os objetivos da Reforma Gerencial, “a lógica da atuação da Administração Pública deixa de

${ }^{69}$ BRESSER PEREIRA, Luiz Carlos, op. cit., p. 23.

70 BRESSER PEREIRA, Luiz Carlos. Da administração pública burocrática à gerencial. In: Reforma do Estado e Administração Pública Gerencial. BRESSER PEREIRA, Luiz Carlos; SPINK, Peter. (orgs.). $6^{\mathrm{a}}$ ed. Rio de Janeiro: Editora FGV, 2005, p. 242/243.

71 BRESSER PEREIRA, Luiz Carlos. Reforma do Estado para a Cidadania. Brasília: ENAP - Escola Nacional de Administração Pública, 1998, p. 146/147.

${ }^{72}$ BERCOVICI, Gilberto. Constituição Econômica e Desenvolvimento. São Paulo: Malheiros, 2005, p. 82. 
ser o controle de procedimentos, ou de meios, para ser pautada pelo controle de resultados, buscando a máxima eficiência possível"73.

A proposta de reforma gerencial de Bresser foi elaborada no Governo Fernando Henrique Cardoso - FHC, tendo como expressão formal o Plano Diretor da Reforma do Aparelho de Estado, de 1995. Incluiu em sua programação uma reforma administrativa, levada a efeito por intermédio da $\mathrm{EC}^{\circ}$ 19/98, a qual, embora integre essa tentativa de modificação estrutural da administração pública brasileira, seja apenas parte da mesma, visto que diversas mudanças não demandavam alteração constitucional ${ }^{74}$. Bresser explicita que:

A Reforma Gerencial tem como documento básico no Brasil o Plano Diretor da Reforma do Aparelho do Estado, de setembro de 1995. Por meio desse documento o governo procurou definir as instituições e estabelecer as diretrizes para a implantação de uma administração pública gerencial. A reforma é gerencial porque busca inspiração na administração das empresas privadas, e porque visa dar ao administrador público profissional condições efetivas de gerenciar com eficiência as agências públicas. É democrática porque pressupõe a existência de regime democrático, porque deixa claro o caráter específico, político, da administração pública, e principalmente porque nela os mecanismos de controle, de caráter democrático, são essenciais para que possa haver delegação de autoridade e controle a posteriori dos resultados ${ }^{75}$.

Um dos instrumentos gerenciais inseridos no texto constitucional por meio da reforma administrativa de FHC foi exatamente a figura do contrato de gestão, previsto no $\S 8^{\circ}$ do art. 37 da Carta de 1988:

Art. 37 (...)
$\S 8^{\circ}$ A autonomia gerencial, orçamentária e financeira dos órgãos e entidades da
administração direta e indireta poderá ser ampliada mediante contrato, a ser firmado
entre seus administradores e o poder público, que tenha por objeto a fixação de metas de
desempenho para o órgão ou entidade, cabendo à lei dispor sobre:
I - o prazo de duração do contrato;
II - os controles e critérios de avaliação de desempenho, direitos, obrigações e
responsabilidade dos dirigentes;
III - a remuneração do pessoal.

Como destaca Gustavo Justino de Oliveira, "a previsão constitucional do contrato de gestão enfatizou a urgência de serem estabelecidos mecanismos de controle de gestão focados na avaliação do desempenho e dos resultados alcançados pelos órgãos e entidades

\footnotetext{
${ }^{73}$ BERCOVICI, Gilberto. Constituição Econômica e Desenvolvimento. São Paulo: Malheiros, 2005, p. 83.

${ }^{74}$ BRESSER PEREIRA, Luiz Carlos, op. cit., p. 18.

${ }^{75}$ Ibid., p. 17/18.
} 
administrativas" ${ }^{, 76}$. Tais instrumentos vêm reforçar o perfil gerencial que se procura imprimir modernamente na administração pública brasileira.

Destarte, a reforma gerencial, bem como a existência de um clamor popular por uma administração pública eficiente e eficaz que atenda às demandas dos cidadãos, serão fonte de permanentes incentivos para a implementação de melhorias na gestão brasileira, incluindo aqui as instituições orçamentárias.

Tal perspectiva se traduz na idéia de orçamento enquanto instrumento gerencial da administração pública. Ou seja, as leis orçamentárias transformam-se em veículos de concretização dos programas, isto é, elos básicos entre planejamento e orçamento, para que seja conferida efetividade à atuação estatal.

A referida teleologia busca maximizar os recursos públicos em prol do atendimento das demandas sociais básicas e do cumprimento dos deveres constitucionais estampados na Constituição Federal.

Contudo, tendo em vista que atendem a múltiplas exigências da vida social, as leis orçamentárias possuirão, em seu corpo, diversos objetivos. Essa diversidade possuirá uma dimensão vertical e outra horizontal, em consonância com as espécies de objetivos que veiculem.

Nesse sentido, pode-se dizer que os objetivos do PPA, enquanto plano de médio prazo, são mais gerais e genéricos, ou, por outro lado, estratégicos. Por ouro lado, os objetivos da LOA se aproximarão do que se pode chamar de objetivos programáticos, visto que são diretamente ligados aos programas e aos problemas que estes procuram resolver. Essa é a dimensão diferenciadora dos objetivos no plano vertical, que decresce do PPA à LOA.

No plano horizontal, cada lei orçamentária possuirá objetivos diversos, previstos em seu próprio corpo. Desse modo, haverá uma diferenciação horizontal dos objetivos de cada uma das peças orçamentárias. Tal característica se deve ao fato de que a lei orçamentária anual, por exemplo, discriminará uma infinidade de programas, em áreas e aspectos profundamente diversos, atendendo a distintos objetivos.

De forma simplificada, pode-se dizer que há três principais espécies de objetivos nas leis orçamentárias: objetivos estratégicos, objetivos fiscais e objetivos programáticos ou operacionais. Enquanto os objetivos estratégicos são amplos e genéricos, à medida que

${ }^{76}$ OLIVEIRA, Gustavo Justino de. Contrato de Gestão. São Paulo: Editora Revista dos Tribunais, 2008, p. 211. 
se desce nos desdobramentos das leis orçamentárias - PPA, LDO e LOA -, a focalização torna-se cada vez mais restrita e detalhada.

Todavia, não somente os objetivos fornecerão a tônica do perfil gerencial que deve orientar a elaboração e execução das leis orçamentárias. Efetivamente, a fixação de objetivos constitui apenas o primeiro momento do planejamento estratégico. Além do estabelecimento dos objetivos que se procura atingir por meio dos estatutos orçamentários, há que se fixar mecanismos de controle, que permitam a aferição do alcance dos objetivos.

Trata-se, exatamente, da mudança de paradigma defendida pelo gerencialismo que se traduz, inclusive, na ênfase que se confere ao controle de resultados em contraposição ao controle de procedimentos, ou de meios. Uma vez que, de acordo com a concepção do orçamento-programa, a alocação de recursos visa à consecução de objetivos e metas ${ }^{77}$, há que se estabelecer controles, a posteriori, que permitam a verificação do atingimento dos objetivos.

Portanto, ao lado do estabelecimento dos objetivos, o controle de resultados assume preponderância em relação ao tradicional controle burocrático de procedimentos. Exatamente, por isso, a reforma gerencial também procura se utilizar do controle de resultados, a partir de indicadores de desempenho ${ }^{78}$. Como descreve Bresser,

\begin{abstract}
A estratégia do controle de resultados foi desenvolvida nos anos 50 por Peter Drucker, como um corolário da política de descentralização da autoridade para as unidades de negócio das empresas. A descentralização implica dar maior autonomia de gestão às unidades descentralizadas. Para isso, é necessário definir objetivos e metas precisos e estabelecer diretrizes claras que orientem os administradores no atingimento dos objetivos. Na administração pública gerencial, o controle de resultados substitui o controle de procedimentos legais ${ }^{79}$.
\end{abstract}

Dois elementos aparecem finalisticamente ligados ao controle de resultados: a mensuração de custos e o estabelecimento de medidas de desempenho. Efetivamente, sem que sejam fixadas medidas de desempenho e mensurados os custos, torna-se impossível a aferição dos resultados obtidos em contraposição àqueles perseguidos.

Sobre isso, Giacomoni aponta que, "durante a execução e especialmente na avaliação final do orçamento, a mensuração indicará se os produtos foram ou não alcançados. Essa será uma medida da própria eficácia da instituição" ${ }^{~}$. Sendo um

\footnotetext{
${ }^{77}$ GIACOMONI, James. Orçamento Público. $13^{\text {a }}$ ed. São Paulo: Atlas, 2005, p. 159.

78 BRESSER PEREIRA, Luiz Carlos. Reforma do Estado para a Cidadania. Brasília: ENAP - Escola Nacional de Administração Pública, 1998, p. 110/111.

${ }^{79}$ Ibid., p. 147.

${ }^{80}$ GIACOMONI, James. Orçamento Público. $13^{\mathrm{a}}$ ed. São Paulo: Atlas, 2005, p. 167.
} 
instrumento de racionalização da gestão financeira estatal, o sistema de mensuração completar-se-á ao conjugar a mensuração física - realizações - com a financeira - custos dos recursos $-{ }^{81}$.

Exatamente por isso, Giacomoni destaca que a principal função da lei orçamentária, ao longo de sua evolução histórica, deslocou-se do controle político para a de instrumento de administração ${ }^{82}$. Entende-se que se trata, na verdade, de incorporação de uma nova função, uma vez que a Lei de Orçamento continuará a representar, nos Estados Democráticos de Direito, instrumento político de controle das atividades do Poder Executivo pelo Legislativo.

De toda forma, a instrumentalização administrativa e gerencial das leis orçamentárias, resultado da evolução dos Estados Modernos, que incorporam critérios de eficiência, eficácia e efetividade em sua atuação, fornecerá elementos imprescindíveis para a análise dos contornos jurídicos dessas leis.

Como destaca José Afonso da Silva, ao verificar o surgimento da técnica do orçamento-programa,

\begin{abstract}
As exigências do planejamento das atividades do poder público determinaram a necessidade de adoção de novas técnicas orçamentárias. Se a administração deve desenvolver-se segundo as regras do planejamento, tendo em vista a satisfação das necessidades da coletividade, era imprescindível que os orçamentos públicos se adequassem a esse novo tipo de administração, para tornar-se num instrumento de ação governamental, voltada para a realização de obras e serviços, em função do desenvolvimento sócio-econômico da comunidade. Daí surgir a técnica do orçamento por programa ou orçamento-programa, que é um tipo de orçamento vinculado ao planejamento das atividades governamentais. Na verdade, o orçamento-programa não é apenas uma peça financeira, é, antes de tudo, um instrumento de execução de planos e projetos de realização de obras e serviços, visando ao desenvolvimento da comunidade. É um documento em que se designam os recursos de trabalho e financeiros destinados à execução dos programas, subprogramas e projetos de execução da ação governamental, classificados por categorias econômicas, por função e por unidades orçamentárias ${ }^{83}$.
\end{abstract}

Nesse sentido, a averiguação da natureza jurídica da lei orçamentária, a ser enfrentada posteriormente neste trabalho, não prescinde de uma profunda análise das transformações sofridas pelas leis orçamentárias ao longo da evolução dos Estados Nacionais e do reconhecimento da mutação sofrida pelos orçamentos na inclusão de perfis administrativos gerenciais.

\footnotetext{
${ }^{81}$ GIACOMONI, James. Orçamento Público. $13^{\mathrm{a}}$ ed. São Paulo: Atlas, 2005, p. 170.

${ }^{82}$ Ibid., p. 64/67.

${ }^{83}$ SILVA, José Afonso da. Orçamento-Programa no Brasil. São Paulo: Revista dos Tribunais, 1973, p. 41.
} 
Tal mutação incorpora, em uma de suas dimensões, a transformação do orçamento em um instrumento gerencial da Administração Pública, por meio do qual se busca a efetivação dos direitos sociais, econômicos e culturais previstos na Constituição.

As leis orçamentárias são, nesse sentido, o principal instrumento concretizador dos valores insculpidos no texto constitucional e, exatamente em função das múltiplas demandas sociais que pretendem atender em contraposição à escassez dos recursos financeiros - por definição limitados -, devem incorporar, obrigatoriamente, critérios de economicidade, eficiência, eficácia e efetividade.

\subsection{Orçamento como instrumento de política fiscal}

A peça orçamentária, no regime de alta inflação, 1981 a 1994, foi seriamente descaracterizada em razão das elevadas e persistentes taxas inflacionárias, que corroíam rapidamente os valores consignados no orçamento inicialmente aprovado, ensejando a necessidade de retificação das dotações ${ }^{84}$.

Por sua vez, a inflação e o desequilíbrio fiscal eram vistos como reflexo da incompatibilidade entre as demandas sociais, devidamente expressas no orçamento pela via das despesas, e a disposição da sociedade em arcar com os respectivos custos por meio da elevação da carga tributária ${ }^{85}$.

O lançamento do Plano Real, em meados de 1994, e o posterior processo de estabilização econômica brasileira, com a progressiva diminuição das taxas inflacionárias e o fim da indexação da economia, permitiram uma modificação substancial no contexto macroeconômico, realçando, a partir de então, a importância do orçamento público.

O plano de estabilização deveria "estar baseado na adoção de um ajuste fiscal que não mais dependesse da inflação para conservar a despesa real contida e que permitisse ao setor público ter um déficit fiscal reduzido, com base em medidas de caráter estrutural, que implicassem uma solução definitiva do déficit público" ${ }^{\text {. }}$. Para Giambiagi e Além,

A grande lição que o fracasso dos planos de estabilização tentados no Brasil na segunda metade dos 1980 e início dos 1990 tinha deixado era que o êxito do combate à inflação dependia da combinação de um mecanismo adequado de desindexação da economia -

${ }^{84}$ GIACOMONI, James. Orçamento Público. $13^{\mathrm{a}}$ ed. São Paulo: Atlas, 2005, p. 259.

85 GIAMBIAGI, Fabio; ALÉM, Ana Cláudia. Finanças Públicas: Teoria e Prática no Brasil. $3^{a}$ ed. São Paulo: Campus/Elsevier, 2008, p. 133.

${ }^{86}$ Ibid., p. 126. 
que não implicasse a quebra dos contratos existentes -, com a adoção de austeras políticas fiscal e monetária ${ }^{87}$.

Não obstante o déficit elevado, o êxito do plano, no que diz respeito ao combate à inflação ao longo de 1994 a1998, foi inequívoco. Todavia, "a combinação de um déficit público elevado com o virtual desaparecimento do imposto inflacionário como fonte de financiamento gerou (...) um aumento da dívida líquida do setor público, que incluindo a base monetária, passou de 30\% do PIB em 1994, para 39\% em 1998"

Como afirmam Além e Giambiagi, os regimes fiscais diferenciam-se de acordo com as espécies de restrições orçamentárias existentes, que podem ser de dois tipos: i) restrição orçamentária fraca; e ii) restrição orçamentária rígida. Na primeira espécie de restrição, o volume de gasto é resultado da soma das diversas demandas sociais e o déficit, o reflexo do desajuste entre a receita auferida e aquelas demandas. Na segunda, condiciona-se a satisfação das demandas à existência de recursos, ou seja, a despesa adapta-se à restrição orçamentária" ${ }^{\# 9}$. Os referidos autores classificam o regime fiscal brasileiro, no período de estabilização, 1995 a 1998, como regime fiscal de restrição orçamentária fraca.

Nessa fase, o regime cambial brasileiro adotado era o de taxas de câmbio fixas, definido como aquele em que o valor da moeda do país em relação às outras divisas é fixo, devendo o Banco Central intervir de modo a equilibrar a oferta e a demanda de divisas no nível da taxa estabelecida ${ }^{90}$.

A economia internacional ainda se recuperava das sucessivas desvalorizações das moedas dos países asiáticos de 1997 quando foi surpreendida pela decretação da moratória russa e desvalorização do rublo, com a consequente retração das fontes de crédito e de financiamento e com a produção de sérias repercussões na economia brasileira ${ }^{91}$.

Com o risco de colapso externo, foram iniciadas negociações com o Fundo Monetário Internacional - FMI para a obtenção de um pacote emergencial de ajuda externa. O ajuda emergencial implicava na adoção de duas medidas simultâneas: i) manutenção da política cambial de microdesvalorizações nominais de $0,6 \%$ ao mês; e ii)

\footnotetext{
${ }^{87}$ GIAMBIAGI, Fabio; ALÉM, Ana Cláudia. Finanças Públicas: Teoria e Prática no Brasil. $3^{\mathrm{a}}$ ed. São Paulo: Campus/Elsevier, 2008, p. 128.

${ }^{88}$ Ibid., p. 137.

${ }^{89}$ Ibid., p. 153

90 GREMAUD, Amaury Patrick; VASCONCELLOS, Marco Antonio Sandoval de; TONETO JÚNIOR, Rudinei. Economia Brasileira Contemporânea. $7^{\text {a }}$ ed. São Paulo: Atlas, 2007, p. 269.

${ }^{91}$ GIAMBIAGI, Fabio; ALÉM, Ana Cláudia, op. cit., p. 160.
} 
produção de um ajuste fiscal por meio da obtenção de superávit do setor público consolidado de 2,60\% do PIB em 1999, de 2,80\% em 2000 e de $3 \%$ em $2001^{92}$.

Nesse momento histórico, e em razão da política de estabilização econômica visada pelo governo, a produção de metas de resultado primário como medida de política fiscal para o combate ao déficit público passa a ser adotada de modo contínuo no cenário econômico brasileiro.

Em 1999, um novo acordo assinado com o FMI contemplou a ampliação das metas de superávit primário consolidado do setor público, como medida de apoio em decorrência da desvalorização da moeda brasileira no contexto da modificação do regime de câmbio. Além disso, como parte das medidas de ajuste fiscal de 1999, foi editada a Lei de Responsabilidade Fiscal - Lei Complementar $n^{\circ}$ 101/2000 -, que passaria a nortear a condução das finanças públicas dos entes federativos brasileiros a partir de então.

Muito embora o novo marco legislativo não produzisse, de imediato, modificações substanciais nas finanças públicas brasileiras, ele foi considerado importante como medida de controle duradouro das contas fiscais dos entes federativos brasileiros.

A partir de 1999, foi fixado o eixo condutor da política econômica brasileira nos anos seguintes: austeridade fiscal, câmbio flutuante e metas de inflação. Nas palavras de Além e Giambiagi,

foram adotadas, simultaneamente, três mudanças que provavelmente moldarão o país por muitos anos. Primeiro, a política fiscal passou a ser baseada na definição de metas de superávit primário relativamente rigorosas. Segundo, a taxa de câmbio tornou-se flutuante. E terceiro, a política monetária passou a ser fixada em função do objetivo de cumprir formalmente as metas de inflação ${ }^{93}$.

Importante significado, nesse contexto, teve a eleição do Presidente Lula, em 2002, com a condução de política fiscal praticamente idêntica àquela produzida no governo Fernando Henrique Cardoso. Aliás, a meta de superávit primário inicial do setor público era de $3,75 \%$ do PIB e foi ampliada para $4,25 \%$ para todo o período do Governo, de 2003 a $2006^{94}$.

Biasoto Júnior destaca ser inegável que:

a década de 1990 seguiu marcada pelo tratamento privilegiado do déficit público dentre as variáveis de política econômica. Desde a tese, amplamente difundida, de que as

\footnotetext{
${ }^{92}$ GIAMBIAGI, Fabio; ALÉM, Ana Cláudia, op. cit., p. 160/161.

${ }^{93}$ Ibid., p. 185.

${ }^{94}$ Ibid., p. 200.
} 
reformas e a privatização do setor produtivo estatal seriam a única garantia de estabilidade fiscal de longo prazo, até a efetiva geração de megassuperávits fiscais com o objetivo de brecar o crescimento da dívida pública, a questão fiscal jamais deixou de ocupar espaço central no debate econômico e na explicação do sucesso da estabilização econômica ${ }^{95}$.

Por conseguinte, a política de manutenção de superávits primários foi iniciada no Governo Fernando Henrique Cardoso e mantida pelo Governo Lula, destinando recursos da ordem de 10\%, desde 1999, para pagamento da dívida pública. Como salientam Fernando Rezende e Armando Cunha, “desrespeitá-la, entretanto, significaria abandonar o controle do endividamento público e, em consequência, alimentar o processo inflacionário, o que nos faria retroceder ao faz-de-conta orçamentário do passado" ${ }^{96}$.

Como se pode visualizar a seguir, os resultados obtidos pelo Governo federal, desde 1999, indicam o esforço do Poder Público para manter a dívida sob controle:

\begin{tabular}{|c|c|}
\hline Ano & $\begin{array}{c}\text { Resultado Primário do } \\
\text { Setor Público (em \% do } \\
\text { PIB) }\end{array}$ \\
\hline 1999 & $3,19 \%$ \\
\hline 2000 & $3,46 \%$ \\
\hline 2001 & $3,64 \%$ \\
\hline 2002 & $3,89 \%$ \\
\hline 2003 & $4,25 \%$ \\
\hline 2004 & $4,59 \%$ \\
\hline 2005 & $4,83 \%$ \\
\hline 2006 & $4,47 \%$ \\
\hline
\end{tabular}

Fonte: Ministério da Fazenda/ Secretaria do Tesouro Nacional.

Com a edição da LRF, a produção das metas de resultado primário e nominal foi expressamente encampada pelo ordenamento jurídico, em consonância com os critérios de

95 BIASOTO Jr., Geraldo. A Polêmica sobre o Déficit Público e a Sustentabilidade da Política Fiscal. In: ALVES PINTO, Márcio Percival; BIASOTO Jr., Geraldo (orgs.). Política Fiscal e Desenvolvimento no Brasil. Campinas: Editora Unicamp, 2006, p. 413.

96 REZENDE, Fernando; CUNHA, Armando. Contribuintes e Cidadãos compreendendo o Orçamento Federal. Rio de Janeiro: FGV, 2002, p. 59/60. 
gestão fiscal responsável. Nesse sentido, essa Lei explicitou a necessidade do estabelecimento das regras fiscais, consubstanciadas nos resultados primário e nominal a serem obtidos pelo Governo.

Consequentemente, passou a compor o projeto de lei de diretrizes orçamentárias o Anexo de Metas Fiscais, em que são estabelecidas metas anuais, em valores correntes e constantes, relativas a receitas, despesas, resultados nominal e primário e montante da dívida pública, para o exercício a que se referirem e para os dois seguintes $\left(\S 1^{\circ}\right.$ do art. $4^{\circ}$ da LRF).

A Lei $n^{\circ}$ 11.439/06, LDO para 2007, por exemplo, no Capítulo I, que trata das metas e prioridades da Administração Pública Federal, consigna expressamente em seu art. $2^{\circ}$ que:

a elaboração e aprovação do Projeto de Lei Orçamentária de 2007 e a execução da respectiva lei deverão ser compatíveis com o obtenção da meta de superávit primário para o setor público consolidado, equivalente a $4,25 \%$ do Produto Interno Bruto - PIB, sendo 2,45\% para os Orçamentos Fiscal e da Seguridade Social e 0,70\% para o Programa de Dispêndios Globais, conforme demonstrado no Anexo de Metas Fiscais constante do Anexo IV desta Lei.

De forma similar, a Lei $\mathrm{n}^{\circ} 11.514 / 07$, LDO para 2008, por sua vez, dispõe em seu art. $2^{\circ}$, que:

\begin{abstract}
a elaboração e aprovação do Projeto de Lei Orçamentária de 2008 e a execução da respectiva Lei deverão ser compatíveis com a obtenção da meta de superávit primário para o setor público consolidado, equivalente a $3,80 \%$ do Produto Interno Bruto - PIB, sendo 2,20\% para os Orçamentos Fiscal e da Seguridade Social e 0,65\% para o Programa de Dispêndios Globais, conforme demonstrado no Anexo de Metas Fiscais constante do Anexo III desta Lei.
\end{abstract}

Em decorrência do aumento nas taxas de inflação no período de abril a junho de 2008, a equipe econômica do Presidente Lula foi autorizada a perseguir uma meta de superávit primário de $4,5 \%$ do $\mathrm{PIB}$, superior, portanto, àquela fixada na $\mathrm{LDO}^{97}$, demonstrando a utilização do orçamento como instrumento de política fiscal.

Efetivamente, os estudiosos das finanças públicas salientam que "no caso da existência de um alto nível de inflação, por sua vez, decorrente de um excesso de demanda

${ }^{97}$ Lula autoriza aperto fiscal de 4,5\% do PIB - Jornal Folha de São Paulo - 08/06/08. 
agregada na economia, o governo pode agir (...) promovendo uma redução da demanda agregada, através da diminuição dos seus gastos (...)"98.

Em síntese, pode-se concluir que o orçamento público, ao acompanhar o desenvolvimento das funções estatais ao longo do século $\mathrm{XX}$, foi refundido, com a alteração de um viés de controle estritamente político para uma ótica de instrumento de política fiscal, em consonância com os fins perseguidos pelo Governo à frente da máquina estatal.

Sua instrumentalização para a implementação de uma determinada política fiscal expansiva ou restritiva - implica em um conteúdo intrínseco de natureza econômica e financeira, estabelecido por meio de metas de resultado primário ou nominal que passam a orientar e conformar todo o processo de execução orçamentária e financeira.

Dessa forma, as metas fiscais contempladas de modo explícito na LDO, e que orientam a execução da LOA, integram o conteúdo jurídico próprio destas leis e oferecem parâmetros válidos para análise e averiguação da conformidade ou desconformidade dos atos praticados pelas autoridades econômicas e pela burocracia estatal em face das peças orçamentárias.

Em síntese, as leis orçamentárias transformaram-se, ao longo de sua evolução histórica, de maneira legítima, em instrumentos de efetivação da política fiscal. Tal conteúdo, que passa a lhes impregnar a essência, traz elementos válidos e absolutamente necessários para a devida análise da validade das medidas adotadas pela burocracia estatal diante dos dispositivos constantes delas.

${ }^{98}$ GIAMBIAGI, Fabio; ALÉM, Ana Cláudia. Finanças Públicas: Teoria e Prática no Brasil. $3^{\text {a }}$ ed. São Paulo: Campus/Elsevier, 2008, p. 15. 


\section{O ORÇAMENTO NO DIREITO COMPARADO}

Este capítulo tem por objetivo apresentar, em linhas gerais, o tratamento conferido por ordenamentos jurídicos estrangeiros relativamente à Lei de Orçamento, possibilitando a comparação entre diversos sistemas orçamentários, suas peculiaridades, notas distintivas e convergências. De modo geral, verifica-se uma ampla tendência nos sistemas orçamentários em relação à adoção de elementos de performance e de verificação do alcance de metas e resultados, bem como de uma estruturação dos orçamentos em programas. Além disso, nos ordenamentos pesquisados encontra-se, sempre, uma preocupação com aspectos fiscais, conferindo-se relevância ao tema dentro do estudo do Orçamento Público.

Estruturou-se o presente capítulo em cinco seções, cada uma dedicada ao exame de um sistema orçamentário estrangeiro. Compõem o panorama forâneo na sequência respectiva: i) Estados Unidos; ii) Chile; iii) México; iv) Portugal; e v) França. Tais investigações apresentam particular relevância, para os objetivos deste trabalho, na medida em que permitem inserir o tratamento de certas questões em outros países, evidenciando eventual conformidade ou desconformidade dado pelo ordenamento jurídico brasileiro.

\subsection{O Orçamento no modelo estadunidense}

A Constituição dos Estados Unidos da América de 1789 institui o princípio da autorização das despesas públicas em seu texto ${ }^{99}$, fixando, de forma clara, a necessidade de obtenção da aprovação do Congresso, pelo Executivo, para utilização dos recursos públicos.

O texto constitucional norte-americano, todavia, não especifica os procedimentos pelos quais se exercita o poder parlamentar, nem tampouco assinala o papel do Presidente da República no processo orçamentário. Para o preenchimento dessas lacunas constitucionais, numerosas leis foram editadas ao longo da história norte-americana. Tais

\footnotetext{
${ }^{99}$ Conforme determina a Constituição Norte-Americana, nenhuma despesa pode ser realizada pelo Tesouro, a não ser em decorrência de apropriações feitas por Lei; e uma regular declaração e conta das receitas e despesas de todo o dinheiro público deve ser publicada periodicamente. No original: "no money shall be drawn from the Treasury, but in consequence of Appropriations made by Law; and a regular Statement and account of Receipts and Expenditures of all public Money shall be published from time to time". (Article I, section 9, clause 7).
} 
estatutos legais são leis 'ordinárias' e se encontram codificadas no Código NorteAmericano (US Code) ${ }^{100}$.

Em relação à maioria dos países ocidentais, o Congresso Norte-Americano apresenta um papel mais ativo e independente no processo orçamentário, além de não possuir limites no exercício de seus poderes de emenda parlamentar ${ }^{101}$.

Os principais diplomas legais pertinentes ao processo orçamentário são:

- Budget and Accounting Act (BAA) - 1921

- Congressional Budget and Impoundment Control Act (CBA) - 1974

- Balanced Budget and Emergency Deficit Control Act (conhecido como Gramm-RudmanHollings Act - GRH) - 1985

- Balanced Budget and Emergency Deficit Control and Reaffirmation Act (GRH) - 1987

- Budget Enforcement Act (BEA) - 1990

- Government Performance and Results Act (GPRA) - 1993

- Line Item Veto Act - 1997

- Budget Enforcement Act (BEA) - 1997

O Budget and Accounting Act (BAA), de 1921, incumbiu o Escritório de Orçamento, antecessor do Departamento de Gerência e Orçamento - Office of Management and Budget - OMB, da atribuição de supervisionar o processo orçamentário dentro do Poder Executivo. O OMB é o órgão central de orçamento nos Estados Unidos, integrando o Departamento Executivo do Presidente dentro da Casa Branca.

Ademais, o BAA instituiu um órgão fiscalizador independente - Departamento Geral de Contabilidade, antecessor do Departamento de Transparência Governamental Government Accountability Office - GAO, para suprir o Congresso com uma auditoria externa das contas governamentais.

O Congressional Budget and Impoundment Control Act (CBA), de 1974, estruturou e organizou o funcionamento das atividades legislativas relativas ao processo orçamentário, criando os Comitês de Orçamento da Câmara e do Senado, bem como o principal órgão de assessoramento parlamentar em matéria orçamentária, qual seja, o Departamento de Orçamento do Congresso (CBO). Além disso, estabeleceu limitações ao

\footnotetext{
${ }^{100}$ OECD Journal on Budgeting. Special Issue. The Legal Framework for Budget Systems. An Internacional Comparison. V. 4, n. 3, 2004, p. 447.

${ }^{101}$ Ibid., p. 451.
} 
exercício do poder de bloqueio das despesas aprovadas pelo Congresso - impoundment power-por parte do Executivo ${ }^{102}$.

O Impoundment Control Act disciplinou dois importantes institutos do ordenamento estadudinense: deferral e rescission, introduzindo a exigência de que o Presidente informasse ao Congresso sempre que um órgão do Poder Executivo pretendesse postergar a despesa, atrasar a assunção de obrigações, não gastar o montante disponível e, também, cancelar a autorização orçamentária - budget authority - outorgada pelo Congresso. Tratase, portanto, do estabelecimento das regras relativas ao impoundment power, que se configura quando o Executivo não utiliza, total ou parcialmente, as dotações estabelecidas na $l \mathrm{ei}^{103}$.

A suspensão da autorização orçamentária - deferral - inclui a possibilidade de atraso ou postergação de obrigações a serem assumidas, como também qualquer ação ou omissão do Executivo que efetivamente impeça a execução imediata de despesas orçamentárias $^{104}$.

A Lei exige que, sempre que o Presidente proponha suspender uma autorização orçamentária, ele deverá transmitir um relatório ao Congresso informando montantes, programa e dotação afetada, estimativa do impacto fiscal e programático, razões para a proposta formulada, fatos e circunstâncias relacionadas com a medida, e período de tempo a que as dotações estarão submetidas à suspensão ${ }^{105}$.

${ }^{102}$ OECD Journal on Budgeting. Special Issue. The Legal Framework for Budget Systems. An Internacional Comparison. V. 4, n., 3, 2004, p. 446/447.

${ }^{103}$ UNITED STATES. COMMITTEE ON THE BUDGET UNITED STATES SENATE. The Congressional Budget Process - An Explanation. U. S. Government Printing Office: Washington, 1998, p. 23. Disponível em [http://budget.senate.gov/democratic/the_budget_process.pdf]. Acesso em 17.07.2009.

${ }^{104}$ Nos termos do Título X, Seção 1011, do CBA: “(1) 'deferral of budget authority' includes - (A) withholding or delaying the obligations or expenditure of budget authority (whether by establishing reserves or otherwise) provided for projects or activities; or - (B) any other type of Executive action or inaction which effectively precludes the obligation or expenditure of budget authority, including authority to obligate by contract in advance of appropriations as specifically authorized by law; (...)".

${ }^{105}$ Nos exatos termos do Título X, Seção 1013, (a), do CBA: “(...) Whenever the President, the Director of the Office of Management and Budget, the head of any department or agency of the United States, or any officer or employee of the United States proposes to defer any budget authority provided for a specific purpose or project, the President shall transmit to the House of Representatives and the Senate a special message specifying-

(1) the amount of the budget authority proposed to be deferred;

(2) any account, department, or establishment of the Government to which such budget authority is available for obligation, and the specific project or governmental functions involved;

(3) the period of time during which the budget authority is proposed to be deferred;

(4) the reasons for the proposed deferral, including any legal authority invoked to justify the proposed deferral;

(5) to the maximum extent practicable, the estimated fiscal, economic, and budgetary effect of the proposed deferral; and

(6) all facts, circumstances, and considerations relating to or bearing upon the proposed deferral and the decision to effect the proposed deferral, including an analysis of such facts, circumstances, and 
De acordo com o referido diploma legal, o deferral somente é permitido para que o Executivo possa enfrentar contingências, tornar possível economia em decorrência de maior eficiência nas operações ou de mudanças em exigências específicas, ou ainda na forma especificamente prevista em lei (Title X, Sec. 1013, 'b’). O instituto não deve ser utilizado para alteração de políticas públicas. Nesse caso, a ação apropriada é o cancelamento da dotação - rescission ${ }_{-}{ }^{106}$.

A aprovação do deferral é automática, a menos que uma das Casas do Congresso adote uma resolução - impoundment resolution - que somente cumpra a função de expressar a desaprovação parlamentar à proposta encaminhada pelo Executivo (Title $X$, Sec. 1011).

O CBA Act também fixou as regras relativas ao cancelamento de autorização orçamentária - rescission -. O Presidente pode propor o cancelamento orçamentário submetendo à apreciação do Congresso uma mensagem especificando o montante a ser cancelado, motivos, contas e programas envolvidos, bem como as estimativas de impacto orçamentário e programático $^{107}$.

Caso o Congresso, dentro do período de 45 dias após o recebimento da mensagem presidencial, não aprove um projeto de lei - rescission bill - ou uma resolução conjunta cancelando os fundos, total ou parcialmente, os recursos deverão ser disponibilizados para utilização pelas agências governamentais. Não poderão ser objeto de nova proposta de

considerations in terms of their application to any legal authority, including specific elements of legal authority, invoked to justify such proposed deferral, and to the maximum extent practicable, the estimated effect of the proposed deferral upon the objects, purposes, and programs for which the budget authority is provided.

A special message may include one or more proposed deferrals of budget authority. A deferral may not be proposed for any period of time extending beyond the end of the fiscal year in which the special message proposing the deferral is transmitted to the House and the Senate".

${ }^{106}$ UNITED STATES. COMMITTEE ON THE BUDGET UNITED STATES SENATE, op. cit., p. 23.

107 De acordo com o Título X, Seção 1012, (a): “(...) Whenever the President determines that all or part of any budget authority will no be required to carry out the full objectives or scope of programs for which it is provided or that such budget authority should be rescinded for fiscal policy or other reasons (including the determination of authorized projects or activities for which budget authority has been provided), or whenever all or part of budget authority provided for only one fiscal year is to be reserved from obligation for such fiscal year, the President shall transmit to both Houses of Congress a special message specifying-

(1) the amount of budget authority which he proposes to be rescinded or which is to be so reserved;

(2) any account, department, or establishment of the Government to which such budget authority is available for obligation, and the specific project or governmental functions involved;

(3) the reasons why the budget authority should be rescinded or is to be so reserved;

(4) to the maximum extent practicable, the estimated fiscal, economic, and budgetary effect of the proposed rescission or of the reservation; and

(5) all facts, circumstances, and considerations relating to or bearing upon the proposed rescission or the reservation and the decision to effect the proposed rescission or the reservation, and to the maximum extent practicable, the estimated effect of the proposed rescission or the reservation upon the objects, purposes, and programs for which the budget authority is provided". 
cancelamento fundos disponibilizados por meio desse procedimento (Title X, Sec. 1012, ' $b$ ').

Uma das principais diferenças entre o deferral e o rescission é que o cancelamento - rescission - somente ocorrerá caso o Congresso aprove um projeto de lei - rescission bill -; o deferral, por outro lado, presume-se aceito, a menos que a Casa adote uma resolução impoundment resolution - manifestando-se de forma contrária à proposta presidencial.

Além disso, o cancelamento orçamentário - rescission - é a medida adequada para modificações pretendidas em face de objetivos de política geral ou fiscal ${ }^{108}$, quando se pretender preservar os recursos orçamentários da utilização de obrigações durante o exercício fiscal ou para modificação do direcionamento das políticas públicas. Por sua vez, a suspensão do uso das dotações - deferral - é medida utilizada para: i) enfrentar contingências; ii) para tornar possível economias em decorrência de maior eficiência nas operações ou de mudanças em exigências específicas; ou, ainda, iii) na forma especificamente prevista em lei.

Como destacam Blöndal, Kraan e Ruffner ao analisarem a sistemática norteamericana, a flexibilidade para não se gastar os recursos previstos no orçamento é menor do que em vários outros países ocidentais. Todavia, as agências não são obrigadas a gastar todos os recursos atribuídos, e os fundos não gastos retornam aos cofres do Tesouro $^{109}$.

Durante as décadas de 1980 e 1990, foi adotada legislação norteada pela necessidade de redução dos déficits orçamentários, diante do seu contínuo crescimento. Em 1985, foi editada a lei conhecida como Graam-Rudman-Hollings (GRH), que estabelecia uma progressão gradativa para a redução dos déficits dos exercícios financeiros do ano de 1986 até 1990 e um orçamento equilibrado para o ano de 1991. Para o alcance desse objetivo, foi criado um mecanismo de cancelamento automático de recursos orçamentários - sequestration - caso o déficit projetado para o exercício fiscal excedesse a $\operatorname{meta}^{110}$.

\footnotetext{
${ }^{108}$ UNITED STATES. COMMITTEE ON THE BUDGET UNITED STATES SENATE, op. cit., p. 23.

109 Nas exatas palavras dos autores referidos: "The flexibility of not spending money is therefore not available to the President as it is in many other OECD member countries (However, agencies are not required to spend all the appropriated monies that have been apportioned to them by OMB, and unspent funds are returned to the Treasury)". Cf. BLÖNDAL, Jón R.; KRAAN, Dirk-Jan; RUFFNER, Michael. Budgeting in the United States. OECD Journal on Budgeting. V. 3, n. 2, 2003, p. 43.

${ }^{110}$ OECD Journal on Budgeting. Special Issue. The Legal Framework for Budget Systems. An Internacional Comparison. V. 4, n. 3, 2004, p. 448.
} 
O GRH Act, contudo, não foi muito efetivo ${ }^{111}$. Com a meta de suprir as falhas da legislação anterior, foi adotado, em 1990, o Budget Enforcement Act (BEA), que estabeleceu dois mecanismos para redução do déficit: níveis agregados (caps) de despesas discricionárias - discretionary spending - e a regra pay-as-you-go (PAYGO), cuja observância era requerida para as despesas obrigatórias - mandatory spending - e para a legislação relativa às receitas ${ }^{112}$. Tecnicamente, o BEA foi uma revisão do GRH Act, com a diferença de ter estabelecido como foco o controle dos custos orçamentários de novas leis adotadas, em contraposição ao déficit ${ }^{113}$.

Caso o OMB estimasse que uma lei de apropriação causaria um aumento do nível geral de despesas discricionárias excedendo, por consequência, os limites estabelecidos em lei, o Presidente deveria emitir uma ordem de sequestro das dotações discricionárias não excepcionadas, por meio de uma redução uniforme ${ }^{114}$.

Por sua vez, de acordo com o princípio $P A Y G O$, qualquer aumento em gastos obrigatórios ou corte de receitas deve ser contrabalanceado, de forma que não haja aumento do déficit ${ }^{115}$. Tal balanceamento pode ser feito tanto por meio de cortes em outras despesas obrigatórias ou por meio de aumento de tributos ${ }^{116}$.

Em síntese, três são as hipóteses que requereriam o acionamento do instituto sequestration como forma de garantia de cumprimento da lei - enforcement -, nos termos em que dispôs o GRH Act (1985), emendado pelo GRH de 1987 e pelo BEA de 1990: i) para assegurar o cumprimento dos limites de gastos discricionários fixados; ii) para garantir o cumprimento da exigência de que qualquer legislação que acarretasse um incremento direto no gasto ou um decréscimo das receitas fosse submetida à regra PAYGO; e iii) para assegurar o cumprimento das metas de déficit especificamente fixadas pelo $\mathrm{CBA}^{117}$.

Na década de 1990, houve uma renovada ênfase na implementação do Orçamento de Desempenho - Performance Budgeting. Em 1993, foi editado o Government

\footnotetext{
111 BLÖNDAL, Jón R.; KRAAN, Dirk-Jan; RUFFNER, Michael. Budgeting in the United States. OECD Journal on Budgeting. V. 3, n. 2, 2003, p. 10.

${ }^{112}$ OECD Journal on Budgeting. Special Issue, op. cit., p. 448.

${ }^{113}$ BLÖNDAL, Jón R.; KRAAN, Dirk-Jan; RUFFNER, Michael, op. cit., p. 10.

${ }^{114}$ Ibid., p. 23.

${ }^{115}$ Ibid., p. 10.

${ }^{116}$ Ibid., p. 25/26.

${ }^{117}$ Nos exatos termos em que dispõe o GRH Act: "1 - to enforce discretionary spending levels assumed in that resolution (with adjustments as provided hereinafter); 2 - to enforce the requirement that any legislation increasing direct spending or decreasing revenues be on a pay-as-you-go basis; and 3 - to enforce the deficit targets specifically set forth in the Congressional Budget and Impoundment Control Act of 1974 with adjustments as provided hereinafter; (...)" (Sec. 250, 'b')
} 
Performance and Results Act (GPRA), que introduziu no ordenamento norte-americano a exigência de que as agências elaborassem planos estratégicos anuais e medidas de desempenho, além de relatórios associados aos resultados obtidos. As agências também deveriam definir sua missão, objetivos de longo prazo e estratégias a serem utilizadas para atingir os resultados definidos ${ }^{118}$.

Com base no GRPA, lançou-se novamente o desafio de se introduzir nos Estados Unidos um Orçamento baseado em desempenho - performance-based budgeting ${ }^{119}$. A principal diferença, em relação às iniciativas reformistas anteriores, refere-se ao fato de a nova reforma ter sido codificada no ordenamento jurídico norte-americano.

Com base nos planos elaborados pelas agências, o OMB - Office and Management Budgeting - passou a incluir um plano de desempenho para o governo federal na proposta orçamentária presidencial. Além disso, o OMB desenvolveu um importante mecanismo para avaliar os programas das entidades públicas, denominado PART - Program Assessment Rating Tool $-{ }^{120}$, ou Ferramenta de Avaliação e Classificação dos Programas, que começou a ser utilizado no exercício de 2003.

O PART é um procedimento sistemático de avaliação que utiliza um questionário para aferição dos resultados obtidos por cada programa, seu gerenciamento, objetivo, desenho e plano estratégico ${ }^{121}$. De acordo com o PART, existem cinco ratings nos quais os programas podem ser classificados como 'efetivo', 'moderadamente efetivo', 'adequado', 'inefetivo' e 'resultados não demonstrados' ${ }^{122}$.

A atribuição de um ranking classificatório aos programas, contudo, não implica em mecânica atribuição de recursos, visto que, em alguns casos, uma classificação de 'inefetivo' ou 'resultados não demonstrados' pode indicar que um montante maior de fundos é necessário para a produção de resultados, enquanto que um programa considerado

\footnotetext{
${ }^{118}$ SHEA, Robert. J. Performance Budgeting in the United States. OECD Journal on Budgeting. Volume 8, número 1, 2008, p. 62.

${ }^{119}$ Como destacam Blöndal, Kraan e Ruffner, op. cit., p. 31/32, "Performance budgeting has a long, if irregular, history on the budget process in the United States, and previous initiatives regardless of their success have been models for the international community. However, 40 years of initiatives to better manage programmes and improve budgetary decision-making have failed to make a substantial impact on the budget process. The alphabet soup of PPBS, MBO and ZBB which began in the 1960s and 1970s all failed to last on a government-wide basis principally because they were presidential initiatives and there was no change in congressional procedure or in law".

${ }^{120}$ OECD Journal on Budgeting. Special Issue. The Legal Framework for Budget Systems. An Internacional Comparison. V. 4, n. 3, 2004, p. 450.

${ }^{121}$ Ibid., p. 450.

${ }^{122}$ OECD Journal on Budgeting. Special Issue. The Legal Framework for Budget Systems. An Internacional Comparison. V. 4, n. 3, 2004, p. 460.
} 
'efetivo' pode ter seus recursos diminuídos porque já não é mais prioritário ou porque concluiu sua missão ${ }^{123}$.

Outras medidas têm sido adotadas nos Estados Unidos visando fortalecer a implementação do Orçamento de Desempenho, a exemplo da Performance Improvement Initiative (PII) - Iniciativa de Aperfeiçoamento da Performance, que busca melhorar a definição de objetivos e o uso da informação relativa ao desempenho no processo de tomada de decisão ${ }^{124}$. As duas principais medidas utilizadas pelo PII são a melhoria da performance do programa e maior investimento em programas que têm obtido êxito ${ }^{125}$.

Como resultado dessas iniciativas, em 2008, sete programas foram encerrados e outros seis tiveram seus recursos reduzidos. Muito embora a decisão alocativa não utilize como critério exclusivo o desempenho, programas que apresentaram melhor performance receberam maiores verbas orçamentárias em relação àqueles que não apresentaram melhorias gerenciais ${ }^{126}$.

O Orçamento do Governo dos Estados Unidos é encaminhado para apreciação do Congresso juntamente com uma mensagem presidencial e um sumário, destacando as prioridades de governo, panorama geral para cada agência, bem como avaliações do desempenho de cada uma delas.

Entre os documentos que acompanham a lei orçamentária ${ }^{127}$, encontra-se um Anexo - The Appendix - utilizado principalmente pelos Comitês de Apropriações e que contém

${ }^{123}$ Nas palavras de Robert J. Shea: "PART ratings do not result in automatic decisions about funding. Clearly, over time, funding should be targeted to programmes that can prove that they achieve measurable results. In some cases, a PART rating of 'ineffective' or 'results not demonstrated' may suggest that greater funding is necessary to overcome identified shortcomings, while a programme rated 'effective' may be in line for a funding decrease because it is not a priority or has completed its mission. However, most of the time, an 'effective' rating is an indication that the programme is using its funding well and that major changes may not be needed". Performance Budgeting in the United States. OECD Journal on Budgeting. Volume 8, número 1, 2008, p. 65.

${ }^{124}$ SHEA, Robert. J. Performance Budgeting in the United States. OECD Journal on Budgeting. Volume 8, número 1, 2008, p. 62.

${ }^{125}$ Como destaca Shea, op. cit., p. 63: "The Performance Improvement Initiative measures its success in two principal ways: - Improved programme performance: Through the use of performance assessments, programmes will improve their performance every year. This is done by creating and tracking each programme's results. The initiative requires each agency to identify weaknesses in programme management and design and then develop and implement clear, aggressive plans to get more for tax dollars every year.

- Greater investment in successful programmes: Overall, scarce resources need to be allocated to higherperforming programmes. Additionally, poorly performing programmes that address a critical need should demonstrate better results. Performance will never be the only factor in decisions about how much funding programmes receive. However, Congress and the President, equipped with information from the Performance Improvement Initiative, can consider performance to a greater degree in their decision making and invest primarily in programmes that provide the greatest return".

${ }^{126}$ SHEA, Robert. J., op. cit., p. 64.

${ }^{127}$ Analytical Perspectives, Historical Tables, The Appendix, Medium-Term macroeconomic framework and fiscal strategy, new measures versus existing expenditure policies, performance-related information and tax expenditures, contingent liabilities and fiscal risks. 
informações financeiras detalhadas sobre os programas e dotações orçamentárias. Esse Anexo inclui, para cada agência, cronogramas de utilização das dotações, explicações das necessidades de fundos, além de outras informações ${ }^{128}$.

A autorização orçamentária - budget authority - concedida pelo Congresso para que as agências governamentais possam incorrer em obrigações que resultarão em pagamentos - outlays - pode decorrer de leis de apropriações - appropriations acts -, necessárias no caso das despesas discricionárias, ou de legislação substantiva, no caso de despesas obrigatórias - mandatory spending.

Para que se compreenda bem a sistemática das apropriações, no contexto norteamericano, é necessário que seja corretamente delineada a separação entre despesas discricionárias e despesas obrigatórias.

As despesas discricionárias dos programas são cobertas por meio das dotações anuais concedidas às agências, que se consubstanciam em limites máximos - tetos- de gastos. Ao contrário, as despesas obrigatórias, resultantes de leis anteriores que concedem direito a benefícios a grupos e/ou indivíduos, possuem a natureza de apropriações permanentes. Os gastos obrigatórios não são afetados pela lógica do processo de apropriações $^{129}$.

Dessa forma, no caso de despesas obrigatórias, não há que se falar em tetos ou limites máximos de gastos, visto que falta discricionariedade para o estabelecimento dos níveis de gastos a serem utilizados. Os gastos obrigatórios são frequentemente referidos como entitlement spending, que representa o maior e principal componente das despesas obrigatórias. A maior parcela das despesas tituladas - entitlement spending - decorre de leis que asseguram a certos indivíduos assistência financeira ou outros benefícios e, assim, os beneficiários que satisfaçam os requisitos legais possuem meios de obrigar o pagamento do benefício pelo Governo caso a obrigação não seja satisfeita, independentemente da previsão orçamentária ${ }^{130}$.

\footnotetext{
${ }^{128}$ OECD Journal on Budgeting. Special Issue. The Legal Framework for Budget Systems. An Internacional Comparison. V. 4, n. 3, 2004, p. 459.

${ }^{129}$ A autorização orçamentária de muitas despesas não é provida por meio das leis de apropriações anuais. Somente os gastos discricionários, cujas contas respondem por cerca de somente 35\% do total das despesas federais são aprovados por meio do processo anual de apropriações. As apropriações são preparadas para programas dentro das contas de cada agência governamental. No texto original, em inglês: "budget authority for many expenditures is not provided in annual appropriations acts. Only discretionary spending, which accounts for only about 35\% of total federal spending, is approved through the annual appropriations process. Appropriations are prepared by programmes within accounts under the heading of each agency". Cf. OECD Journal on Budgeting. Special Issue, op. cit., p.450.

130 "The fundamental characteristic of mandatory spending is the lack of annual discretion to establish spending levels. (...) Mandatory spending is frequently referred to as entitlement spending. Entitlement
} 
As despesas discricionárias também podem ser definidas residualmente, como aquelas que não são despesas obrigatórias ${ }^{131}$, encontrando-se sujeitas às decisões alocativas anuais do processo orçamentário e, em particular, às prescrições das leis de apropriações appropriations acts -. Caso o Congresso decida diminuir os fundos destinados a certo programa, poderá simplesmente reduzir as dotações anuais a serem consignadas ${ }^{132}$.

As leis de apropriações concedem a autorização orçamentária necessária para que as agências assumam obrigações e para que o Tesouro Norte-Americano efetue o pagamento $^{133}$. Além disso, tais projetos de leis recebem o mesmo tratamento conferido aos demais: "An appropriations bill is treated as a regular legislative bill and is sent to the President for approval or veto" ${ }^{\prime 134}$.

As dotações são estruturadas por contas - accounts -, frequentemente divididas em diferentes programas associados a cada agência governamental ${ }^{135}$. A estrutura das apropriações dentro do ordenamento norte-americano inclina-se para um controle pormenorizado das movimentações orçamentárias pelo Congresso, em dissonância com a moderna tendência mundial de agregação de despesas em categorias ampliadas e foco nos resultados $^{136}$. Blöndal, Kraan e Ruffner defendem o mesmo entendimento, salientando que, enquanto que a tendência internacional é agrupar parcelas maiores de recursos em poucos itens de apropriação, os Estados Unidos mantêm um sistema de apropriações extremamente detalhado acerca das despesas de cada programa ${ }^{137}$.

spending is a subset of mandatory spending and represents the largest component of mandatory spending. Most entitlement spending is pursuant to laws that provide all eligible individuals (or an entity or unit of government) with financial assistance or other benefits. An entitlement represents a binding obligation on the part of the Federal Government; eligible recipients have legal recourse to compel payment from the government if the obligation is not fulfilled. Usually, the laws providing for an entitlement contain formulas or criteria that specify who is eligible for Federal assistance. Unless the underlying law establishing the entitlement is modified, these individuals retain a legal right to benefits, regardless of the budget situation". Cf.. UNITED STATES. COMMITTEE ON THE BUDGET UNITED STATES SENATE, op. cit., p. 5.

${ }^{131}$ OECD Journal on Budgeting. Special Issue, op. cit., p. 449.

${ }^{132}$ UNITED STATES. COMMITTEE ON THE BUDGET UNITED STATES SENATE, op. cit., p. 6.

${ }^{133}$ OECD Journal on Budgeting. Special Issue, op. cit., p. 465.

${ }^{134}$ BLÖNDAL, Jón R.; KRAAN, Dirk-Jan; RUFFNER, Michael, op. cit., p. 18.

135 "Approved appropriations are by 'accounts'. There are some 1.000 appropriation accounts, which are often subdivided into different programmes within agencies. There are generally separate accounts for larger capital expenditures and transfers. A 'salaries and expenses' account may cover several programmes in a given department”. OECD Journal on Budgeting. Special Issue. The Legal Framework for Budget Systems. An Internacional Comparison. V. 4, n. 3, 2004, p. 465.

${ }^{136}$ Como destaca o Jornal de Orçamento da OCDE: "The appropriation structure is quite complex, reflecting the high degree of control exercised by Congress in the approval process. The detailed and unstable appropriation structure contrasts with the international trend to group expenditures into a few appropriations where programme outcomes are the focus at the legislative approval stage not approval of individual projects and other inputs". OECD Journal on Budgeting. Special Issue. The Legal Framework for Budget Systems. An Internacional Comparison. V. 4, n. 3, 2004, p. 465.

${ }^{137}$ Nas palavras dos autores: “(...) congressional control is extremely detailed and extensive, far and away more detailed than any other country. While the international trend is to group larger amounts of 
Existem treze subcomitês de apropriações em cada uma das Casas do Congresso ${ }^{138}$, cada um dos quais é responsável por uma lei de apropriação, resultando na elaboração de treze diferentes projetos de leis de apropriações. Em função disso, há tradições e práticas diversas nos respectivos subcomitês acerca da flexibilidade outorgada às várias entidades governamentais no uso das dotações, o que dificulta generalizações a esse respeito ${ }^{139}$.

De toda forma, em face da extensão dos poderes enfeixados pelo Congresso Norteamericano, a modificação dos itens da estrutura de programação orçamentária é cerceada, sendo conferida limitada flexibilidade ao Executivo ${ }^{140}$.

Enquanto houve consenso quanto à necessidade de manutenção da disciplina fiscal, os dispositivos constantes do Budget Enforcement Act (BEA) funcionaram relativamente bem $^{141}$. Contudo, em 2002, expirou-se a vigência daquele diploma legal, e suas regras não foram reeditadas ${ }^{142}$.

Ante tal ausência, as duas Casas do Congresso devem estabelecer um acordo quanto ao total de receitas e despesas e outros agregados ${ }^{143}$, o que é realizado por meio de uma resolução orçamentária - budget resolution -. Estabelecidos os níveis agregados de despesa pela resolução, o montante é subdividido entre os subcomitês, resultando em subtotais de despesas que não podem ser excedidos no processo de alocação orçamentária $^{144}$.

Quando o novo exercício fiscal é iniciado, caso as leis de apropriações não tenham sido votadas e promulgadas, haverá necessidade da edição de resoluções provisórias continuing resolutions -, que fornecerão a autorização orçamentária temporária para que as atividades governamentais não sejam interrompidas ${ }^{145}$.

expenditures into single appropriations items, the United States maintains an appropriations system that exerts extremely detailed control over spending for individual programmes”. BLÖNDAL, Jón R.; KRAAN, Dirk-Jan; RUFFNER, Michael. Budgeting in the United States. OECD Journal on Budgeting. Volume 3, número 2, 2003, p. 25.

${ }^{138}$ BLÖNDAL, Jón R.; KRAAN, Dirk-Jan; RUFFNER, Michael, op. cit., p. 24.

${ }^{139}$ Ibid., p. 42.

140 "The executive has very limited discretion to change any line item of the approved budget: Congress is quite specific when it adopts the appropriations acts. Transfers between the 1.000 or so accounts require congressional approval. In rare cases, Congress has granted transfer authority to certain entities. For example, the Department of Defense may transfer up to $10 \%$ from one account to another, within the Department. Transfers between programmes within an account (reprogramming) take place. Congress generally writes into appropriations acts the rules for reprogramming, which is allowed only up to small amounts". Cf. OECD Journal on Budgeting. Special Issue, op. cit., p. 469.

${ }^{141}$ BLÖNDAL, Jón R.; KRAAN, Dirk-Jan; RUFFNER, Michael, op. cit., p. 29.

${ }^{142}$ Ibid., p. 16.

143 "a formal and binding agreement between the two chambers on total spending, receipts and other budget aggregates". Ibid., p. 21.

${ }_{144}$ OECD Journal on Budgeting. Special Issue, op. cit., p. 463.

145 Ibid., p. 464. 
O Presidente tem duas opções quando recebe as leis de apropriações: aprová-las ou vetá-las integralmente. Em 1998, a Suprema Corte Norte-Americana julgou inconstitucional o Line-Item Veto Act, de 1995, que facultava ao Presidente o exercício de veto no nível de linhas ou itens de despesa - line-item veto power - constantes do Orçamento $^{146}$.

Em qualquer momento do ano, o Presidente pode submeter ao Congresso propostas de dotações suplementares - supplementary appropriations - necessárias, seja em decorrência de leis posteriormente editadas ou em razão de interesse público. Devem ser incluídas na proposta as razões e explicações referentes às mudanças solicitadas (US Code, Title 31, Sec. 1107).

Posteriormente ao final de cada exercício financeiro, as agências governamentais devem preparar e submeter, ao Presidente e ao Congresso, um relatório sobre o desempenho de cada programa, com os respectivos indicadores de performance, comparando-se os resultados obtidos em relação aos objetivos previamente estipulados. $\mathrm{O}$ Relatório deve, ainda, avaliar o sucesso na obtenção das metas fixadas e o desempenho do programa relativamente ao plano anteriormente traçado e, ainda, de conter as devidas explicações e justificativas para o não atingimento das metas fixadas ${ }^{147}$.

Frise-se que, além disso, o Congresso norte-americano pode requisitar, a qualquer momento, informações e relatórios que entenda necessários a respeito das atividades do Poder Executivo ${ }^{148}$. A análise do sistema orçamentário estadudinense termina por destacar

${ }^{146}$ OECD Journal on Budgeting. Special Issue, op. cit., p. 451.

${ }^{147}$ No texto exato da codificação norte-americana (USCode), Título 31, Seção 1116:

“(a) No later than 150 days after the end of an agency's fiscal year, the head of each agency shall prepare and submit to the President and the Congress, a report on program performance for the previous fiscal year.

(b) (1) Each program performance report shall set forth the performance indicators established in the agency performance plan under section 1115 , along with the actual program performance achieved compared with the performance goals expressed in the plan for that fiscal year. (...)

(d) Each report shall-

(1) review the success of achieving the performance goals of the fiscal year;

(2) evaluate the performance plan for the current fiscal year relative to the performance achieved toward the performance goals in the fiscal year covered by the report;

(3) explain and describe, where a performance goal has not been met (including when a program activity's performance is determined not to have met the criteria of a successful program activity under section 1115(b)(1)(A)(ii) or a corresponding level of achievement if another alternative form is used)-

(A) why the goal was not met;

(B) those plans and schedules for achieving the established performance goal; and

(C) if the performance goal is impractical or infeasible, why that is the case and what action is recommended; (...)".

148 BLÖNDAL, Jón R.; KRAAN, Dirk-Jan; RUFFNER, Michael. Budgeting in the United States. OECD Journal on Budgeting. V. 3, n. 2, 2003, p. 22. 
o extenso papel desempenhado pelo Congresso quando comparado às funções desempenhadas pelos Parlamentos em outros países ${ }^{149}$.

\subsection{O Orçamento no ordenamento chileno}

A Constituição da República Chilena assegura ao Presidente da República a iniciativa exclusiva dos projetos de lei relativos à administração financeira e orçamentária do Estado, incluindo as modificações da Lei de Orçamento ${ }^{150}$.

Ademais, dispõe sobre as competências que o Congresso Nacional pode exercitar relativamente à matéria orçamentária, estabelecendo que o Parlamento não poderá aumentar nem diminuir a estimativa dos ingressos e somente poderá reduzir os gastos contidos no projeto da Lei de Orçamento, salvo os que estejam estabelecidos por lei permanente, além de adotar o instituto do decurso de prazo naquele país ${ }^{151}$.

As mencionada disposições constitucionais permitem entrever a modesta influência exercida pelo Congresso em termos de processo orçamentário, característica essa reforçada pela análise de outras restrições ${ }^{152}$.

O Comitê de Orçamento é único para as duas Câmaras do Congresso e composto por 26 membros, distribuídos de forma equânime entre a Câmara dos Deputados e o Senado. Em 2003, tal Comitê foi efetivamente estabelecido como Comissão permanente ${ }^{153}$.

\footnotetext{
${ }^{149}$ Ibid., p. 16/17.

150 “Art. 65(...) Corresponderá al Presidente de la República la iniciativa exclusiva de los proyectos de ley que tengan relación con la alteración de la división política o administrativa del país, o con la administración financiera o presupuestaria del Estado, incluyendo las modificaciones de la Ley de Presupuestos, y con las materias señaladas en los números 10 y 13 del artículo 63”.

151 “Art. 67. El proyecto de Ley de Presupuestos deberá ser presentado por el Presidente de la República al Congreso Nacional, a lo menos com tres meses de anterioridad a la fecha en que debe empezar a regir; y si el Congreso no lo despachare dentro de los sesenta días contados desde su presentación, regirá el proyecto presentado por el Presidente de la República. El Congreso Nacional no podrá aumentar ni disminuir la estimación de los ingresos; solo podrá reducir los gastos contenidos en el proyecto de Ley de Presupuestos, salvo los que estén establecidos por ley permanente. La estimación del rendimiento de los recursos que consulta la Ley de Presupuestos y de los nuevos que establezca cualquiera otra iniciativa de ley, corresponderá exclusivamente al Presidente, previo informe de los organismos técnicos respectivos. No podrá el Congreso aprobar ningún nuevo gasto con cargo a los fondos de la Nación sin que seindiquen, al mismo tiempo, las fuentes de recursos necesarios para atender dicho gasto. Si la fuente de recursos otorgada por el Congreso fuere insuficiente para financiar cualquier nuevo gasto que se apruebe, el Presidente de la República, al promulgar la ley, previo informe favorable del servicio o institución a través del cual se recaude el nuevo ingreso, refrendado por la Contraloría General de la República, deberá reducir proporcionalmente todos los gastos, cualquiera que sea su naturaleza".

${ }^{152}$ Conforme destacam Blöndal e Curristine: "The Congress (...) may not reallocate expenditures between programmes. (...) The Congress may not scrutinise arms purchases by the military. This applies to the $10 \%$ of the gross revenue of the government-owned copper mining company (CODELCO) which must be transferred to the military". In BLÖNDAL, Jón R.; CURRISTINE, Teresa. Budgeting in Chile. OECD Journal on Budgeting. V. 4, n. 02, 2004, p. 21.
} 
No ordenamento jurídico chileno, a par das disposições constitucionais, destacamse como principais leis que compõem e disciplinam o processo orçamentário ${ }^{154}$ :

- $\quad$ Lei n ${ }^{\circ} 1.263 / 75$, conhecida como Lei Orgânica de Administração Financeira;

- $\quad$ Lei $n^{\circ} 18.575 / 86$, que estabelece as bases gerais da Administração Pública;

- Decreto n 106/60 do Ministério da Fazenda, que define as atribuições específicas da Direção de Orçamentos; e

- $\quad$ Lei ${ }^{\circ} 19.553 / 98$, que cria mecanismos de incentivos institucionais.

O Decreto-lei no 1.263/75, ou Lei Orgânica de Administração Financeira - LOAF, estabelece, em seu art. $5^{\circ}$, que o sistema orçamentário chileno está constituído por um programa financeiro de médio prazo e por orçamentos anuais devidamente coordenados entre $\mathrm{si}^{155}$.

As despesas são definidas como autorizações máximas de gasto franqueadas ao Poder Executivo, na forma em que dispõe o art. 19: “los presupuestos de gastos son estimaciones del límite máximo a que pueden alcanzar los egresos y compromisos públicos $(\ldots)$ ".

Na concepção chilena, os objetivos e metas fixados compõem e estruturam a lei orçamentária, consoante a definição estampada no art. 11 do referido diploma legal: “El presupuesto del Sector Público consiste en una estimación financiera de los ingresos y gastos de este sector para un año dado, compatibilizando los recursos disponibles con el logro de metas y objetivos previamente establecidos".

A estruturação orçamentária encontra-se fundamentada na utilização da categoria programa, que se define como um conjunto de atividades necessárias, integradas e articuladas para prover certos bens ou serviços, com vistas a alcançar um propósito

\footnotetext{
${ }^{153}$ Ibid., p. 21.

${ }^{154}$ CHILE. MINISTERIO DE HACIENDA. DIRECCIÓN DE PRESUPUESTOS. El proceso presupuestario en Chile, Aspectos generales: Marco Legal, Actores Institucionales, Principales Aspectos de Modernización, septiembre, 2005. Disponível em [http://www.dipres.cl/572/articles-22542_doc_pdf.pdf]. Acesso em 20.10.08.

${ }^{155}$ Art. $5^{\circ}$. "El sistema presupuestario estará constituido por un programa financiero de mediano plazo y por presupuestos anuales debidamente coordinados entre sí. Tanto en el programa financiero como en el presupuesto se establecerán las prioridades y se asignarán recursos globales a sectores, sin perjuicio de la planificación interna y de los presupuestos que corresponda cobrar a los servicios integrantes”.
} 
específico em relação a determinado segmento populacional de modo a resolver um problema existente ou atender uma necessidade que o afete ${ }^{156}$.

A análise de fatores externos que podem interferir no resultado do programa é considerada, dentro da sistemática orçamentária chilena. Efetivamente, para se assegurar o êxito de um programa não basta que se executem todas as atividades necessárias para produzir os resultados visados, na quantidade e qualidade previstas. Também se deve identificar os fatores externos que concorrem para que o programa cumpra, ou não, seu objetivo, a exemplo de riscos ambientais, financeiros, institucionais e sociais ${ }^{157}$. Também em função disso, não é feita uma associação direta e automática entre resultados obtidos e apropriações $^{158}$.

Para que sejam atingidos os objetivos constantes da lei orçamentária, são fixadas dotações, ou limites máximos de dispêndios a que se pode recorrer. Todavia, as dotações não se configuram como obrigatórias e, sim, como autorizações máximas de gasto. Nas palavras de Blöndal e Curristine: "The appropriations are considered maximums, i.e. there is not an obligation to spend appropriated funds" ${ }^{\prime 159}$.

Complementando a sistemática orçamentária do Chile, os arts. 51 e 52 da LOAF previram a necessidade do estabelecimento de um sistema de controle financeiro, com o objetivo primordial de verificar o cumprimento dos fins e obtenção das metas fixadas pelo Setor Público, in verbis:

Artículo. 51. El sistema de control financiero comprende todas las acciones orientadas a cautelar y fiscalizar la correcta administración de los recursos del Estado. Verificará fundamentalmente el cumplimiento de los fines, el acatamiento de las disposiciones legales y reglamentarias y la obtención de las metas programadas por los servicios que integran el Sector Público.

Artículo $52^{\circ}$ Corresponderá a la Contraloría General de la República, en cuanto al control financiero del Estado, fiscalizar el cumplimiento de las disposiciones legales y

\footnotetext{
${ }^{156}$ Conforme expressamente definido nas instruções do Órgão Central de Orçamento Chileno: "Un conjunto de actividades necesarias, integradas $\mathbf{y}$ articuladas para proveer ciertos bienes y/o servicios (componentes), tendientes a lograr un propósito específico en una población objetivo de modo de resolver un problema o atender una necesidad que la afecte". CHILE. MINISTERIO DE HACIENDA. DIRECCIÓN DE PRESUPUESTOS. Instrucciones del Formulario e Presentácion de Programas al Presupuesto, p. 02. Disponível em [http://www.dipres.cl/572/articles-37391_doc_pdf.pdf]. Acesso em 22.05.09.

157 Cf. "Metodologia para elaboração de Matriz de Marco Lógico", p. 07. Disponível em [http://www.dipres.cl/572/articles-37369_doc_pdf.pdf]. Acesso em 01.06.09.

${ }_{158}$ Nas palavras de Blöndal e Curristine: "The Chilean system of performance budgeting does not automatically and directly link performance to appropriations. It does not mechanically cut funding to programmes that fail to meet targets or increase the funding of programmes that achieve results. The Ministry of Finance has in fact sought to avoid the mechanical associations of budget allocations to performance measures" BLÖNDAL, Jón R.; CURRISTINE, Teresa. Budgeting in Chile. OECD Journal on Budgeting. V. 4, n. 02, 2004, p. 40.

${ }^{159}$ BLÖNDAL, Jón R.; CURRISTINE, Teresa, op. cit., p. 28.
} 
reglamentarias que dicen relación con la administración de los recursos del Estado y efectuar auditorías para verificar la recaudación, percepción e inversión de sus ingresos y de las entradas propias de los servicios públicos. La verificación y evaluación del cumplimiento de los fines y de la obtención de las metas programadas para los servicios públicos son funciones que competen a la Administración del Estado y cuyo ejercicio corresponde al Ejecutivo. Conforme a lo dispuesto en el inciso precedente, anualmente se efectuará la evaluación de los programas sociales, de fomento productivo y de desarrollo institucional incluidos en los presupuestos de los servicios públicos que se determinen mediante uno o más decretos del Ministerio de Hacienda, con sujeción a los procedimientos, entidades participantes, marcos de referencia y mecanismos que se establezcan en el o los respectivos decretos. Asimismo, los órganos y servicios públicos regidos por el título II de la ley $\mathrm{N}^{\mathrm{o}} 18.575$, deberán confeccionar y difundir anualmente un informe que incluya una cuenta de gestión operativa y económica del año precedente, con el cumplimiento de objetivos, tareas y metas, de acuerdo a las instrucciones que imparta el Ministerio de Hacienda. Los informes que se emitan por aplicación de los dos incisos anteriores, deberán remitirse a ambas ramas del Congreso Nacional en la oportunidad que se fije em los decretos e instrucciones respectivas.

Desde 1997, as leis orçamentárias anuais estabelecem que os órgãos do Governo Central têm a obrigação de proporcionar informação acerca de seus objetivos, metas de gestão e resultados. Também deve acompanhar o projeto de Lei de Orçamento um Informe de Finanzas Públicas ${ }^{160}$.

A Lei Orçamentária deve ser acompanhada de um conjunto de indicadores de desempenho e suas correspondentes metas. A apresentação das medidas de desempenho no Orçamento é feita indicando-se, para cada medida, produto estratégico institucional, fórmula de cálculo, valor do indicador em anos anteriores, meta fixada e meios de verificação. O cumprimento dos indicadores transforma-se no Balanço de Gestão Integral (BGI) das instituições governamentais, constituindo informação para o próximo exercício orçamentário $^{161}$.

Em 1998, com a edição da Lei $n^{\circ}$ 19.553, iniciou-se o desenvolvimento dos Programas de Aperfeiçoamento da Gestão, associando o cumprimento dos objetivos de gestão a um incentivo de caráter monetário para os funcionários, correspondente a um incremento da remuneração, sempre que a instituição tivesse alcançado um grau de cumprimento maior ou superior a $90 \%$ dos objetivos fixados para o ano ${ }^{162}$.

A partir do ano de 2000, a Dirección de Presupuestos iniciou a implementação de um sistema de avaliação e controle da gestão pública. Tal iniciativa permitiu a criação de um modelo de avaliação e acompanhamento do desempenho da gestão orçamentária,

\footnotetext{
${ }^{160}$ CHILE. MINISTERIO DE HACIENDA. DIRECCIÓN DE PRESUPUESTOS. El proceso presupuestario en Chile, Aspectos generales: Marco Legal, Actores Institucionales, Principales Aspectos de Modernización, septiembre, 2005, p. 22. Disponível em [http://www.dipres.cl/572/articles-22542_doc_pdf.pdf]. Acesso em 20.10.08.

${ }^{161}$ Ibid., p. 24.

${ }^{162}$ Ibid., p. 24.
} 
incorporando os conceitos de orçamento por resultados nas diferentes etapas do processo orçamentário $^{163}$. A característica central desse processo é o uso dos resultados da avaliação de políticas públicas na etapa de formulação orçamentária, de modo a orientar decisões alocativas de recursos e de mudanças na gestão das instituições públicas ${ }^{164}$.

Essesistema de avaliação de desempenho é composto por três diferentes linhas de atuação: i) Avaliação dos Programas Governamentais (EPG); ii) Avaliações de Impacto; e iii) Avaliação Total do Gasto - Evaluación Comprehensiva del Gasto - ${ }^{165}$. As principais diferenças referem-se ao nível de abrangência das avaliações e entidade responsável pela execução da avaliação.

No caso da Avaliação dos Programas Governamentais (EPG), o Executivo submete uma proposta de programas a serem avaliados no ano seguinte ao Congresso. Depois de terem sido escolhidos os programas, consultores externos são selecionados para conduzir as avaliações. O relatório final de avaliação conterá resultados e recomendações, que abordam os problemas detectados e que demandam melhorias ${ }^{166}$.

Considerando tais recomendações, pode-se classificar os programas existentes em cinco categorias gerais ${ }^{167}$ : i) ajustes menores; ii) modificações de desenho ou processos de gestão interna; iii) redesenho substantivo do programa; iv) reubicación institucional; e v) encerramento ou substituição integral do programa.

A Avaliação de Impacto difere da primeira por serem contratadas entidades de pesquisa ou Universidades para a realização das avaliações, além de serem mais caras e demoradas. Em razão dessas características, as avaliações de impacto são geralmente utilizadas para programas que representem grandes montantes de recursos públicos ${ }^{168}$.

Por último, existem as Avaliações Totais de Gastos - Comprehensive Spending Review -, que examinam a estrutura, funções, missão, objetivos, planos estratégicos e gerenciais do Ministério ou Agência, bem como se a utilização dos recursos públicos pela entidade pública observa os princípios da economia, eficiência e efetividade.

163 CHILE. MINISTERIO DE HACIENDA. DIRECCIÓN DE PRESUPUESTOS. Informe de Finanzas Públicas. Proyecto de Ley de Presupuestos del Sector Público para el año 2009. Octubre 2008, p. 123. Disponível em [http://www.dipres.cl/572/articles-41339_doc_pdf.pdf]. Acesso em 22.05.09.

${ }^{164}$ CHILE. MINISTERIO DE HACIENDA. DIRECCIÓN DE PRESUPUESTOS. El proceso presupuestario en Chile, Aspectos generales: Marco Legal, Actores Institucionales, Principales Aspectos de Modernización, septiembre, 2005, p. 23.

165 Ibid. p. 24.

${ }^{166}$ BLÖNDAL, Jón R.; CURRISTINE, Teresa, op. cit., p. 35.

${ }^{167}$ Cf. Informe de Finanzas Públicas, p. 130.

${ }^{168}$ BLÖNDAL, Jón R.; CURRISTINE, Teresa, op. cit., p. 36. 
Os relatórios finais desta espécie de Avaliação são publicados na internet e encaminhados ao Congresso e as respectivas recomendações são discutidas com o órgão avaliado, para que sejam implementadas. Além disso, como consequência são firmados acordos formais entre o Ministério da Fazenda e o referido Ministériopara implementação dos compromissos estabelecidos ${ }^{169}$.

A avaliação de programas e instituições vale-se da metodologia de marco lógico, que é utilizada por organismos multilaterais de desenvolvimento, a exemplo do Banco Mundial e do Banco Interamericano de Desenvolvimento - BID. Essa metodologia permite avaliar a consistência dos objetivos e do desenho do programa, dos aspectos de sua organização e gestão, bem como dos resultados apresentados, considerando-se os produtos (cobertura, focalização, entre outros).

A política fiscal chilena, desde 2001, orienta-se em conformidade com o objetivo de produção de superávit estrutural equivalente a $1 \%$ do $\operatorname{PIB}^{170}$. A importância de se propiciar informações claras sobre os objetivos de política fiscal dos governos é destacada nos principais Códigos de boas práticas orçamentárias do mundo ${ }^{171}$.

Várias razões são destacadas para a introdução dessas regras fiscais: i) o Chile pretendeu formalizar a prudência fiscal que tem caracterizado o gerenciamento das finanças governamentais; ii) o estabelecimento de uma regra formal contribui para aumentar a transparência e previsão da condução da política fiscal; e iii) tal regra permite a operacionalização de uma política fiscal anticíclica, dentro de parâmetros de responsabilidade fiscal $^{172}$.

A partir de 2001, definições estratégicas e indicadores de desempenho são apresentados pelos órgãos no projeto de Lei de Orçamentos. Os indicadores de desempenho são uma ferramenta que agrega informação quantitativa relativa ao alcance do resultado na entrega dos produtos estratégicos (bens ou serviços) gerados pela instituição. As definições estratégicas, dentro do modelo chileno, incorporam a missão, objetivos estratégicos, produtos (bens e serviços providos pela instituição) e seus clientes/usuários/beneficiários.

\footnotetext{
${ }^{169}$ BLÖNDAL, Jón R.; CURRISTINE, Teresa, op. cit., p. 36.

${ }^{170}$ Ibid., p. 17.

${ }^{171}$ Ibid., p. 17.

${ }^{172}$ Como destacam Blöndal e Curristine: "There were several reasons advanced in Chile for the introduction of this rule: - First, Chile wanted to formalise the fiscal prudence that has characterised the management of government finances. (...) - Second, a formal rule served to increase transparency and predictability in the conduct of fiscal policy. - Third, this allowed Chile to operate a counter-cyclical fiscal policy within an overall framework of fiscal responsibility”. BLÖNDAL, Jón R.; CURRISTINE, Teresa, op. cit., p. 12.
} 
Os indicadores de desempenho são definidos como uma ferramenta que entrega informação quantitativa acerca do nível de alcance dos objetivos de um programa, podendo cobrir aspectos quantitativos ou qualitativos ${ }^{173}$. Embora registrem, principalmente, o desempenho em termos de produtos - bens e serviços produzidos -, também podem se referir a resultados finais - impacto alcançado pelo programa na sociedade -

Desde 2003, os resultados das avaliações também são apresentados à Comissão Especial Mista de Orçamentos do Congresso. Adicionalmente, informações sintéticas dessas avaliações acompanham o projeto de Lei de Orçamentos de cada ano ${ }^{174}$.

O ciclo orçamentário chileno é dividido em duas fases bem distintas ${ }^{175}$. A primeira se concentra na avaliação crítica do andamento dos programas e atualização da linha de base - baseline -. A segunda focaliza a distribuição de recursos de um fundo - Bidding Fund - para novos programas e expansão dos programas em execução, de acordo com uma análise prévia de viabilidade e disponibilidade de recursos ${ }^{176}$.

A segunda fase do processo orçamentário, inaugurada em 2000 com a criação do Fundo de Ofertas - Bidding Fund -, tem por objetivo conter a tradicional natureza incremental do processo orçamentário ${ }^{177}$. Isso é feito exigindo-se dos Ministérios que priorizem a solicitação de recursos de novas iniciativas por ordem de importância. Além disso, melhora-se a qualidade técnica das requisições, uma vez que essas encontram-se sujeitas à análise e a uma espécie de "concorrência" entre agências diversas do Governo ${ }^{178}$.

\footnotetext{
${ }^{173}$ Em outros termos: "una herramienta que entrega información cuantitativa respecto del nivel de logro alcanzado por un programa, pudiendo cubrir aspectos cuantitativos o cualitativos de este logro. Es una expresión que establece una relación entre dos o más variables, la que comparada con períodos anteriores, productos (bienes o servicios) similares o una meta o compromiso, permite evaluar desempeño". Cf. CHILE. MINISTERIO DE HACIENDA. DIRECCIÓN DE PRESUPUESTOS. Metodologia para elaboração de Matriz de Marco Lógico, p. 04. Disponível em [http://www.dipres.cl/572/articles-37369_doc_pdf.pdf]. Acesso em 01.06.09.

${ }^{174}$ Cf. Informe de Finanzas Públicas, p. 129.

${ }^{175}$ Ibid., p. 14.

${ }^{176}$ O Fundo de Ofertas é uma espécie de conta de recursos livres, disputada pelos Ministérios que podem oferecer propostas para novos programas ou para ampliar ou reformular programas existentes. Essencialmente, o Fundo é um mecanismo para alocação de novos recursos, contudo, é desenhado de modo a oferecer incentivos para que as agências introduzam indicadores de performance e objetivos. Na lição de Blöndal e Curristine: “(...) the Bidding Fund is a pool of unallocated resources to which ministries can submit bids either for new programmes or to substantially extend or reformulate existing programmes. Essentially the Fund is a device for allocating new funds; however, it is designed in a way that provides incentives for agencies to introduce formal performance indicators and targets". BLÖNDAL, Jón R.; CURRISTINE, Teresa. Budgeting in Chile. OECD Journal on Budgeting. V. 4, n. 02, 2004, p. 38.

${ }^{177}$ BLÖNDAL, Jón R.; CURRISTINE, Teresa, op. cit., p. 17.

${ }^{178}$ Conforme Blöndal e Curristine, "The Budget Office analyses the various bids that have been submitted based on two criteria. The first is the technical quality of the bid. The second is the consistency of the bid with the political priorities of the President. (...) Based on these criteria, the Budget Office proposes a list of new initiatives to be funded". Ibid., p. 18.
} 
Para que o Fundo seja relevante em termos políticos, de modo a propiciar as melhorias desejadas dentro da sistemática orçamentária, há que se assegurar um volume razoável de recursos para posterior distribuição ${ }^{179}$.

A estrutura das dotações ou apropriações, na sistemática chilena, é relativamente simples. Existem apenas duas para cada ministério e/ou agência consignando os montantes globais para despesas operacionais: uma para recursos humanos e outra para compra de bens e serviços. Não existem divisões em subitens de gastos específicos dentro de cada uma destas duas dotações genéricas, além de serem as apropriações consideradas limites máximos de dispêndios ${ }^{180}$.

Há duas espécies de restrições para a utilização de cada apropriação. Uma refere-se aos gastos relativos a quatro itens de despesa: horas-extras, viagens, treinamento e consultores. A outra varia de acordo com regras estabelecidas para projetos específicos, que repercutem no gerenciamento da dotação de cada agência governamental ${ }^{181}$.

De forma geral, a estrutura das dotações no Chile enseja maior amplitude da flexibilidade gerencial e operacional para os gestores ${ }^{182}$. De outro lado, as informações relativas à performance têm sido extensivamente utilizadas no processo de formulação orçamentária, favorecendo a integração entre os resultados obtidos e as decisões alocativas $^{183}$, no rumo da implementação de um efetivo Orçamento de Desempenho (performance-based budget).

\subsection{O Orçamento no ordenamento jurídico mexicano}

O Ordenamento Jurídico Mexicano apresenta um amplo e minucioso tratamento da matéria orçamentária, em contraposição àquele conferido pela Constituição Federal dos Estados Unidos Mexicanos, que dispõe vagamente sobre o processo orçamentário.

\footnotetext{
${ }^{179}$ Novamente, como destacam Blöndal e Curristine: "The budget office strives to ensure that the Fund is sufficiently large to be relevant in political terms. This has meant a Fund that is about $2.5 \%$ of total spending on average in recent years". Ibid., p. 18

${ }^{180}$ BLÖNDAL, Jón R.; CURRISTINE, Teresa. Budgeting in Chile. OECD Journal on Budgeting. V. 4, n. 02, 2004, p. 28.

181 “(...) There are two types of restriction. The first is common to all accounts and includes a maximum amount that can be spent on four items of expenditure: overtime, travel, training and consultants. The amount of the restriction originates with the Ministry of Finance in the budget proposal presented to the Congress. The budget also contains a ceiling on the number of staff (posts) and the number of vehicles that each ministry and agency may have. The second type is restrictions for specific appropriations. These generally earmark parts of a larger appropriation for specific projects. This can be viewed as simply a pragmatic approach to programme budgeting". Ibid., p. 28.

${ }_{182}^{182}$ Ibid., p. 29.

${ }^{183}$ BLÖNDAL, Jón R.; CURRISTINE, Teresa. Budgeting in Chile. OECD Journal on Budgeting. V. 4, n. 02, 2004, p. 19.
} 
A Carta Mexicana introduz o princípio da aprovação do Orçamento pelo Parlamento, fixando, como faculdade exclusiva da Câmara de Deputados, a aprovação anual do Orçamento das Despesas da Federação, bem como o exame prévio, discussão e modificação do projeto encaminhado pelo Executivo ${ }^{184}$. Ademais, determina que não poderá haver qualquer espécie de despesa que não esteja compreendida no Orçamento, ou determinada por lei posterior ${ }^{185}$.

Por sua vez, há menção expressa de que os recursos econômicos utilizados pelo Governo deverão ser utilizados com eficiência, eficácia e honradez para satisfazer os objetivos aos quais se encontrem vinculados ${ }^{186}$.

O texto constitucional mexicano não distribui as competências orçamentárias entre o Poder Executivo e o Legislativo. Destarte, tal delineamento deve ser procurado na respectiva legislação infraconstitucional.

O principal diploma legal mexicano que dispõe sobre o Orçamento Público é a Ley Federal de Presupuesto y Responsabilidad Hacendaria -LFPRH, de 30 de março de 2006, que substituiu a Ley de Presupuesto, Contabilidad y Gasto Público Federal, de 31 de dezembro de 1976.

Nota particular deste ordenamento é a existência de um Orçamento composto por duas leis - Orçamento dual -: Ley de Ingressos e Presupuesto de Egresos. Enquanto que em alguns regimes orçamentários a Lei de Orçamentos aprova as receitas e fixa as despesas, por meio de um único diploma legal, no ordenamento mexicano, uma lei aprova as receitas e outra, as despesas. Nas palavras de Mabarak Cerecedo:

(...) en la mayoría de los países con regímenes jurídicos financieros semejantes al que se tiene implantado en México, tanto la Ley de Ingresos como el presupuesto de egresos son dos leyes diferentes en su mecánica aplicativa, pero se correlacionan debido a que ambas contienen normas que regulan el anverso y reverso del fenómeno financiero del Estado $^{187}$.

\footnotetext{
184 “Artículo 74. Son facultades exclusivas de la Cámara de Diputados: (...) IV. Aprobar anualmente el Presupuesto de Egresos de la Federación, previo examen, discusión y, en su caso, modificación del Proyecto enviado por el Ejecutivo Federal, una vez aprobadas las contribuciones que, a su juicio, deben decretarse para cubrirlo, así como revisar la Cuenta Pública del año anterior. (...)”.

185 “Artículo 126. No podrá hacerse pago alguno que no esté comprendido en el Presupuesto o determinado por ley posterior".

186 “Artículo 134. Los recursos económicos de que dispongan el Gobierno Federal y el Gobierno del Distrito Federal, así como sus respectivas administraciones públicas paraestatales, se administrarán con eficiencia, eficacia y honradez para satisfacer los objetivos a los que estén destinados".

187 MABARAK CERECEDO, Doricela. Derecho Financiero Público. $3^{\mathrm{a}}$ ed. México: McGraw-Hill Interamericana, 2007, p. 27.
} 
$\mathrm{O}$ art. 16 da LFPRH estrutura a forma de elaboração e apresentação da Lei de Orçamento, definindo como elementos essenciais: objetivos anuais, estratégias e metas; projeções das finanças públicas; e resultados das finanças públicas, incluindo as medidas de política fiscal utilizadas para o alcance dos objetivos, estratégias e metas ${ }^{188}$.

A estrutura programática, já indicada no referido dispositivo como modeladora do Orçamento, é definida logo no artigo $2^{\circ}$ da Ley Federal de Presupuestos como o conjunto de categorias e elementos programáticos ordenados de forma coerente, em que se definem as ações a serem desempenhadas pelos ordenadores de despesa para alcançar os objetivos e metas, de acordo com as políticas definidas no Plano Nacional de Desenvolvimento e nos programas e orçamentos ${ }^{189}$. Além disso, a estrutura programática deverá incluir indicadores de desempenho, com suas correspondentes metas anuais (art. 27, II, da LFPRH).

De acordo com a concepção normativa do Orçamento no México, o programa se constitui em elemento central do sistema orçamentário, a orientar, por meio dos objetivos e metas, a atuação governamental. A própria atividade institucional dos órgãos públicos encontra-se definida "con el fin de dar cumplimiento a los objetivos y metas contenidos en los programas" (art. 20, I, da LFPRH).

Ademais, a par de sua estruturação por programas, o ordenamento mexicano inclina-se em direção à concepção de Orçamento de Desempenho - Performance Budget -. Precisamente por isso, a orçamentação deverá considerar a avaliação dos resultados obtidos pelas entidades em cumprimento a objetivos e metas do Plano Nacional de Desenvolvimento e dos programas constantes do Orçamento, nos termos em que dispõe o art. 25 da LFPRH:

\footnotetext{
${ }^{188}$ Nos exatos termos do dispositivo da Lei Mexicana: “Artículo 16. La Ley de Ingresos y el Presupuesto de Egresos se elaborarán con base en objetivos y parámetros cuantificables de política económica, acompañados de sus correspondientes indicadores del desempeño, los cuales, junto con los criterios generales de política económica y los objetivos, estrategias y metas anuales, en el caso de la Administración Pública Federal, deberán ser congruentes con el Plan Nacional de Desarrollo y los programas que derivan del mismo, e incluirán cuando menos lo siguiente: (...) II. Los objetivos anuales, estrategias y metas; III. Las proyecciones de las finanzas públicas (...); IV. Los resultados de las finanzas públicas (...) Los criterios generales de política económica explicarán las medidas de política fiscal que se utilizarán para el logro de los objetivos, las estrategias y metas, así como las acciones que correspondan a otras políticas que impacten directamente en el desempeño de la economia (...)".

${ }^{189}$ Nos termos da Lei: "Artículo 2. Para efectos de esta Ley, se entenderá por: (...) XXII. Estructura Programática: el conjunto de categorías y elementos programáticos ordenados en forma coherente, el cual define las acciones que efectúan los ejecutores de gasto para alcanzar sus objetivos y metas de acuerdo con las políticas definidas en el Plan Nacional de Desarrollo y en los programas y presupuestos, así como ordena y clasifica las acciones de los ejecutores de gasto para delimitar la aplicación del gasto y permite conocer el rendimiento esperado de la utilización de los recursos públicos; (...)”.
} 
Artículo 25. La programación y presupuestación anual del gasto público se realizará (...) con base en: (...) III. La evaluación de los avances logrados en el cumplimiento de los objetivos y metas del Plan Nacional de Desarrollo y los programas sectoriales con base en el Sistema de Evaluación del Desempeño, las metas y avances físicos y financieros del ejercicio fiscal anterior y los pretendidos para el ejercicio siguiente; (...).

Tal concepção, contudo, não é nova dentro da discussão doutrinária mexicana. $\mathrm{Na}$ década de 1970, Saldaña já defendia que a estruturação do Orçamento por programas

es una técnica programático-financiera que busca establecer relaciones estrechas entre los objetivos anuales fijados y los recursos necesarios para alcanzar estos objetivos. En sí, es un sistema de asignación de recursos que promueve el logro y satisfacción de las necesidades, mediante el uso racional de los mismos.

Esta nueva mecánica busca no solo controlar el presupuesto en cuanto al gasto, sino que además ejerza un control en relación al gasto autorizado en función de programas concretos asegurando se cumplan de acuerdo a ellos; esto es, a grupos de actividades dirigidas hacia el mismo objetivo. Esta técnica permite que se evalúe la eficiencia y eficácia en el gasto y en la productividad ${ }^{190}$.

A respeito da mudança de orientação do Orçamento Tradicional para o Orçamento

de Desempenho ou Orçamento por Programas, interessante síntese é feita por Marabak

Cerecedo:

En el sistema presupuestal tradicional se hacía un simple listado de partidas en numerario que se asignaban a cada unidad administrativa para la satisfacción de sus necesidades, pero no se expresaba cómo, cuándo y para qué se determinarían esas cantidades. Por consiguiente, cada órgano de autoridad gozaba de libertad para emplear las partidas de recursos que le eran asignadas en las tareas que consideraba importantes. Esto motivaba frecuentemente una dispersión de esfuerzos y, muchas veces, también el empalme o repetición de gastos en una misma actividad, cuando no el dispendio, derroche o el gasto inútil de cuantiosas sumas de dinero público. Por ello, en la más moderna técnica presupuestaria es ya común hablar del presupuesto programático, que consiste en que en primer lugar se elabora un plan de trabajo en el que se planea la actividad, con la descripción de manera detallada y precisa de las necesidades que en cierta área o materia experimenta la sociedad; en segundo lugar, se trazan los objetivos mediante los que se deberá satisfacer esa necesidad; en tercer lugar se describen las actividades a realizar por el órgano público, estableciendo con precisión tiempos y movimientos; en seguida se realiza una estimación de dinero del costo de la actividad programada para ese ejercicio fiscal, y, finalmente, se efectúa la calendarización de las partidas presupuestales para fijar fechas adecuadas para su asignación. El presupuesto por programas es, en consecuencia, el sistema técnico más adelantado que existe para racionalizar y optimizar el gasto público en beneficio de la sociedad ${ }^{191}$.

190 SALDAÑA, Adalberto. Teoria y Practica del Presupuesto por Programas en Mexico. Campestre Churubusco: Instituto Nacional de Administración Pública, 1977, p. 16.

${ }^{191}$ MABARAK CERECEDO, Doricela, op. cit., p. 31. 
Outros dispositivos indicam a juridicização do Orçamento de Desempenho no ordenamento mexicano. A título exemplificativo, demonstra-se o que determina o art. 45 da Lei Federal de Orçamento do México:

Artículo 45. Los responsables de la administración en los ejecutores de gasto serán responsables de la administración por resultados; para ello deberán cumplir con oportunidad y eficiencia las metas y objetivos previstos en sus respectivos programas, conforme a lo dispuesto en esta Ley y las demás disposiciones generales aplicables (...).

O sistema de avaliação do desempenho deve permitir a valoração objetiva do desempenho dos programas, de acordo com o grau de cumprimento de metas e objetivos, com base em indicadores estratégicos e de gestão que permitam conhecer o impacto social dos programas (art. 2 $2^{\circ}$ LI, da LFPRH). Os princípios orientadores da avaliação do desempenho, bem como sua caracterização, encontram-se estampados no artigo 111 da Ley Federal de Presupuesto:

Artículo 111. La Secretaria y la Función Pública, en el ámbito de sus respectivas competencias, verificarán periódicamente, al menos cada bimestre, los resultados de recaudación y de ejecución de los programas y presupuestos de las dependencias y entidades, con base en el sistema de evaluación del desempeño, entre otros, para identificar la eficiencia, economía, eficacia, y la calidad en la Administración Pública Federal y el impacto social del ejercicio del gasto público, así como aplicar las medidas conducentes. Igual obligación y para los mismos fines, tendrán las dependencias, respecto de sus entidades coordinadas.

Dicho sistema de evaluación del desempeño a que se refiere el párrafo anterior del presente artículo será obligatorio para los ejecutores de gasto. Dicho sistema incorporará indicadores para evaluar los resultados presentados en los informes bimestrales, desglosados por mes, enfatizando en la calidad de los bienes y servicios públicos, la satisfacción del ciudadano y el cumplimiento de los criterios establecidos en el párrafo segundo del artículo 1 de esta Ley. (...)

Los indicadores del sistema de evaluación del desempeño deberán formar parte del Presupuesto de Egresos e incorporar sus resultados en la Cuenta Pública, explicando en forma detallada las causas de las variaciones y su correspondiente efecto económico.

Los resultados a los que se refiere este artículo deberán ser considerados para efectos de la programación, presupuestación y ejercicio de los recursos.

O Orçamento das Despesas (Presupuesto de Egresos) deverá utilizar, pelo menos, as seguintes classificações (art. 28 da LFPRH): administrativa (agrupa as previsões de gasto conforme as unidades executoras da despesa); funcional e programática (agrupa as previsões conforme os resultados pretendidos, em termos de funções, programas, projetos, atividades, indicadores, objetivos e metas); econômica (agrupa as dotações de despesa em função da natureza econômica do gasto) e geográfica (agrupa as previsões de gasto com base na destinação geográfica da despesa). 
O ordenamento mexicano também prevê que toda proposta de aumento ou criação de despesas no projeto de Presupuesto de Egresos deverá ser acompanhada da correspondente iniciativa de receita que suporte o novo gasto ou de compensação por meio da redução em outras previsões de despesas, nos termos do art. 18 da LFPRH:

Artículo 18. A toda propuesta de aumento o creación de gasto del proyecto de Presupuesto de Egresos, deberá agregarse la correspondiente iniciativa de ingreso distinta al financiamiento o compensarse con reducciones en otras previsiones de gasto. Sin perjuicio de lo dispuesto en el artículo 54, no procederá pago alguno que no esté comprendido en el Presupuesto de Egresos o determinado por ley posterior, en este último caso primero se tendrá que aprobar la fuente de ingresos adicional para cubrir los nuevos gastos, en los términos del párrafo anterior.

Las comisiones correspondientes del Congreso de la Unión, al elaborar los dictámenes respectivos, realizarán una valoración del impacto presupuestario de las iniciativas de ley o decreto, con el apoyo del Centro de Estudios de las Finanzas Públicas de la Cámara de Diputados, y podrán solicitar opinión a la Secretaría sobre el proyecto de dictamen correspondiente.

El Ejecutivo Federal realizará una evaluación del impacto presupuestario de las iniciativas de ley o decreto que presente a la consideración del Congreso de la Unión.

Outro dispositivo da Lei Federal de Orçamento insere normas de disciplina orçamentária, destacando que a diminuição de receitas públicas previstas na Ley de Ingresos poderá ser compensada por meio da "reducción de los montos aprobados en los presupuestos de las dependencias, entidades, fondos y programas" (art. 21, III, da LFPRH). A Lei Mexicana dispõe, inclusive, a ordem de redução de despesas a ser utilizada na hipótese:

Artículo 21. (...)

a) Los ajustes deberán realizarse en el siguiente orden:

i) Los gastos de comunicación social;

ii) El gasto administrativo no vinculado directamente a la atención de la población;

iii) El gasto en servicios personales, prioritariamente las erogaciones por concepto de percepciones extraordinarias, y

iv) Los ahorros y economías presupuestarios que se determinen con base en los calendarios de presupuesto autorizados a las dependencias y entidades.

En caso de que los ajustes anteriores no sean factibles o suficientes para compensar la disminución de ingresos, podrán realizarse ajustes en otros conceptos de gasto siempre y cuando se procure no afectar los programas sociales; (...).

No casos de queda de arrecadação, prevê-se duas hipóteses, de acordo com a legislação mexicana:

$1^{\text {a) }}$ caso o montante da redução seja de até 3\% das receitas dos impostos (art. 21, III, 'b', da LFPRH); 
$2^{\mathrm{a}}$ ) caso o montante necessário de redução seja superior a $3 \%$ da receita de impostos (art. 21, III, 'c', da LFPRH).

Nao primeira, o Poder Executivo enviará à Câmara dos Deputados um informe que contenha o montante do gasto programado a ser reduzido, juntamente com a composição da referida redução, por órgão e entidade. Dessa forma, a decisão cabe ao Executivo, que informará as modificações necessárias à Câmara.

Na segunda hipótese, o Executivo encaminhará o montante de gasto a ser reduzido e uma proposta de composição da citada redução por órgão e entidade. Com base neste segundo caso,

(...) La Cámara de Diputados, por conducto de la Comisión de Presupuesto y Cuenta Pública, en un plazo de 15 dias hábiles a partir de la recepción de la propuesta, analizará la composición de ésta, con el fin de proponer, en su caso, modificaciones a la composición de la misma, en el marco de las disposiciones generales aplicables. El Ejecutivo Federal, con base en la opinión de la Cámara, resolverá lo conducente de acuerdo a las prioridades aprobadas en el presupuesto informando de ello a la misma. En caso de que la Cámara no emita opinión dentro de dicho plazo, procederá la propuesta enviada por el Ejecutivo Federal (...).

Assim, muito embora a Câmara tenha que ser ouvida a respeito, a decisão final também caberá ao Poder Executivo, visto que este não ficará vinculado à opinião exarada pela Casa Legislativa quanto à repartição do contingenciamento, uma vez que deverá decidir em conformidade às prioridades estabelecidas no próprio orçamento.

Trimestralmente, deverão ser entregues ao Congresso relatórios informativos a respeito dos ingressos obtidos e da execução do Orçamento, bem como sobre a situação econômica e das finanças públicas do respectivo exercício financeiro. De mais a mais, devem ser incluídos os principais indicadores sobre os resultados e avanços dos programas, em cumprimento aos objetivos e metas estipulados (art. 107 da LFPRH).

Nos termos do art. 110 da Lei Federal de Orçamento mexicana, as metas dos programas serão analisadas e avaliadas pelas Comissões Ordinárias da Câmara dos Deputados, in verbis:

Artículo 110. La Secretaría realizará trimestralmente la evaluación económica de los ingresos y egresos en función de los calendarios de presupuesto de las dependencias y entidades. Las metas de los programas aprobados serán analizadas y evaluadas por las Comisiones Ordinarias de la Cámara de Diputados. (...)

La evaluación del desempeño se realizará a través de la verificación del grado de cumplimiento de objetivos y metas, con base en indicadores estratégicos y de gestión que permitan conocer los resultados de la aplicación de los recursos públicos federales. (...). 
Outro dispositivo pertinente à atuação do Congresso Mexicano é representado pelo artigo 42 da LFPRH, o qual determina que, no processo de exame, discussão, modificação e aprovação da Ley de Ingresos e do Presupuesto de Egresos, o Legislativo deverá observar critérios técnicos nas estimativas de ingressos de recursos, além da obrigatoriedade de se produzir o ajuste necessário no caso de inclusão de novo projeto, por meio de redução em outros projetos ou de novas fontes de recursos:

“Artículo 42.

(...) En el proceso de examen, discusión, modificación y aprobación de la Ley de Ingresos y del Presupuesto de Egresos, los legisladores observarán los siguientes principios:

(...)

b) Las estimaciones de las fuentes de ingresos, distintas a la señalada en el inciso anterior, deberán sustentarse en análisis técnicos;

c) Cuando propongan un nuevo proyecto, deberán señalar el ajuste correspondiente de programas y proyectos vigentes si no se proponen nuevas fuentes de ingresos;

(...)

e) En su caso, se podrán proponer acciones para avanzar en el logro de los objetivos planteados en el Plan Nacional de Desarrollo y los programas que deriven del mismo; y

f) En el caso del Presupuesto de Egresos, la Comisión de Presupuesto y Cuenta Pública de la Cámara de Diputados deberá establecer mecanismos de participación de las Comisiones Ordinarias en el examen y discusión del Presupuesto por sectores. Los legisladores de dichas Comisiones deberán tomar en cuenta en sus consideraciones y propuestas la disponibilidad de recursos, así como la evaluación de los programas y proyectos y las medidas que podrán impulsar el logro de los objetivos y metas anuales. $(\ldots)$.

As unidades executoras das despesas orçamentárias devem sujeitar-se aos montantes autorizados no Orçamento das Despesas - Presupuesto de Egresos -. Todavia, podem ser realizadas adequações orçamentárias - adecuaciones presupuestarias - em razão de necessidades operacionais e programáticas.

A LFPRH apresenta elucidativa definição das adequações orçamentárias, da seguinte forma:

"Artículo 2. Para efectos de esta Ley, se entenderá por:

II. Adecuaciones presupuestarias: las modificaciones a las estructuras funcional programática, administrativa, y económica, a los calendarios de presupuesto y las ampliaciones y reducciones al Presupuesto de Egresos o a los flujos de efectivo correspondientes, siempre que permitan un mejor cumplimiento de los objetivos de los programas a cargo de los ejecutores de gasto; (...)".

Portanto, as adequações orçamentárias são definidas em função dos objetivos dos programas, na medida em que sempre devem permitir um melhor alcance das metas fixadas, ou, por outras palavras, um melhor cumprimento da Lei de Orçamento. Os arts. 58 
e 59 da Ley Federal de Presupuesto desenvolvem tal conceituação, explicitando as duas espécies de adequações orçamentárias previstas no ordenamento, bem como suas hipóteses de cabimento ${ }^{192}$.

As adequações orçamentárias internas são realizadas diretamente pelas unidades orçamentárias e não requerem autorização por parte da Secretaria da Fazenda (Secretaria de Hacienda y Crédito Público); por sua vez, no caso de adequações orçamentárias externas, haverá necessidade de se requerer autorização da Secretaria da Fazenda. Nas palabras de Mabarak Cerecedo:

La modificación, reducción, sustitución e incluso la supresión de programas o subprogramas de actividades, sólo se podrán efectuar con autorización expresa del jefe del Ejecutivo; serán manifestadas mediante los órganos administrativos encargados de la administración del presupuesto. Cualquier transferencia de partidas de un programa a otro, únicamente podrá hacerse con la previa justificación y autorización de la dependencia encargada de la administración presupuestaria. Para ello, la unidad administrativa responsable deberá presentar con anticipación su solicitud de autorización, acompañada de las justificaciones específicas de cada caso.

Por último, la dependencia encargada de administrar el presupuesto de egresos deberá evaluar periódicamente el ejercicio presupuestal, en función de los objetivos y de los programas aprobados ${ }^{193}$.

${ }^{192}$ Nos termos do art. 58 da LFPRH: "Artículo 58. Las adecuaciones presupuestarias se realizarán siempre que permitan un mejor cumplimiento de los objetivos de los programas a cargo de las dependencias y entidades, y comprenderán:

I. Modificaciones a las estructuras: a) Administrativa; b) Funcional y programática; c) Económica; y d) Geográfica;

II. Modificaciones a los calendarios de presupuesto; y

III. Ampliaciones y reducciones líquidas al Presupuesto de Egresos o a los flujos de efectivo correspondientes.

El Reglamento establecerá las adecuaciones presupuestarias externas de las dependencias que requerirán la autorización de la Secretaría y el procedimiento correspondiente, así como aquél para las adecuaciones de las entidades a que se refiere el artículo siguiente.

Las adecuaciones presupuestarias internas serán autorizadas por las propias dependencias y entidades informando al respecto a la Secretaría, en los términos de lo dispuesto en el Reglamento.

Cuando las adecuaciones presupuestarias representen en su conjunto o por una sola vez una variación mayor al 5 por ciento del presupuesto total del ramo de que se trate o del presupuesto de una entidad, la Secretaría deberá reportarlo en los informes trimestrales. Con base en esta información, la Comisión de Presupuesto y Cuenta Pública podrá emitir opinión sobre dichas adecuaciones".

Por sua vez, o art. 59 dispõe da seguinte forma: "Artículo 59. Las entidades requerirán la autorización de la Secretaria únicamente para realizar las siguientes adecuaciones presupuestarias externas:

I. En el caso de las entidades que reciban subsidios y transferencias:

a) Traspasos de recursos de gasto de inversión y obra pública a gasto corriente;

b) Traspasos que impliquen incrementar el presupuesto total regularizable de servicios personales de la entidad;

c) Cambios a los calendarios de presupuesto no compensados;

d) Las modificaciones que afecten los balances de operación primario y financiero;

e) Las modificaciones a los subsidios que otorguen con cargo a recursos presupuestarios; y

f) Las erogaciones adicionales con cargo a ingresos excedentes.

II. En el caso de las entidades que no reciban subsidios y transferencias, respecto de las adecuaciones a que se refieren los incisos b), d) y f) anteriores".

${ }^{193}$ MABARAK CERECEDO, Doricela, op. cit., p. 32. 
As adequações orçamentárias encontram-se sempre orientadas pelo princípio da flexibilidade, que "permite adoptar medidas correctivas dentro del proceso operativo"194. A maior flexibilidade concedida aos gestores do orçamento é uma das bases fundamentais da implementação do Orçamento de Desempenho, conforme destacam os mais recentes e modernos estudos realizados nessa área.

Somente no caso de as modificações orçamentárias representarem, em conjunto ou separadamente, uma variação maior que $5 \%$ do orçamento total de uma entidade, haverá necessidade de que tal informação conste dos Relatórios Trimestrais encaminhados ao Congresso.

A LFPRH prevê que, nessas hipóteses, a Comissão de Orçamento e Contas Públicas poderá emitir opinião sobre as referidas modificações. Contudo, não há menção sobre o modus operandi dessa competência parlamentar, nem tampouco indicação clara sobre a natureza dessa prerrogativa - se cabe ao Congresso dar a palavra final a respeito da adequação orçamentária ou se tal 'opinião' seria meramente protocolar -. A mais, somente nessa hipótese há menção quanto à necessidade de autorização parlamentar para que se proceda a modificações no Orçamento.

O Regulamento Mexicano da LFPRH, de 28 de junho de 2006, em seu Título IV (Del Ejercicio del Gasto Público Federal) - Capítulo III (arts. 92 a 104), desenvolve a temática das adequações orçamentárias, dentro dos delineamentos legais traçados pela Lei Federal mexicana - adequações orçamentárias externas e internas -.

O referido ordenamento ainda prevê a responsabilização dos gestores no caso da realização de ações ou omissões que impeçam o alcance dos objetivos e metas anuais fixados, além do descumprimento das disposições legais mexicanas relativas à orçamentação:

Artículo 114. Se sancionará en los términos de las disposiciones aplicables a los servidores públicos que incurran en alguno de los siguientes supuestos:

(...)

II. No cumplan con las disposiciones generales en materia de programación, presupuestación, ejercicio, control y evaluación del gasto público federal establecidas en esta Ley y el Reglamento, así como en el Decreto de Presupuesto de Egresos;

(...)

VIII. Realicen acciones $\mathrm{u}$ omisiones que impidan el ejercicio eficiente, eficaz $\mathrm{y}$ oportuno de los recursos y el logro de los objetivos y metas anuales de las dependencias, unidades responsables y programas.

${ }^{194}$ SALDAÑA, Adalberto, op. cit., p. 99. 
O resultado final da execução do Orçamento deve ser levado ao conhecimento do Congresso, em cumprimento ao ditame constitucional mexicano, para que as Contas Públicas sejam analisadas e julgadas:

\begin{abstract}
Con esta denominación (la cuenta pública) se conoce al resultado final que presenta un presupuesto de egresos después de haberse realizado su ejercicio. A la formulación de la cuenta pública contribuyen todas las unidades administrativas que durante el ejercicio manejaron y ejercieron partidas presupuestarias. (...)

el jefe del Ejecutivo deberá presentar oportunamente esta cuenta pública al órgano legislativo correspondiente para su análisis, estudio y aprobación. En México, esta exigencia se encuentra asentada en la fracción IV del artículo 74 de la Constitución, en donde se señala a la Cámara de Diputados como el cuerpo legislativo que tiene la faculdad de efectuar la revisión y aprobación de dicha cuenta ${ }^{195}$.
\end{abstract}

Em linhas gerais, encontra-se o ordenamento jurídico mexicano norteado pelas tendências mundiais em relação à estruturação por programas e concentração de esforços ao estabelecimento de um controle de resultados, com ampla avaliação do desempenho alcançado pelos órgãos e entidades.

\title{
2.4 O Orçamento no sistema orçamentário português
}

A Constituição Portuguesa de 1976, atualizada em conformidade com a VII Revisão Constitucional, de 2005, em sua Parte II (Organização econômica), Títulos II (Planos) e IV (Sistema financeiro e fiscal), aborda temas diretamente relacionados ao processo orçamentário português.

O sistema político português é semipresidencial. É um sistema misto que conta com um presidente e um primeiro-ministro, sendo aquele eleito diretamente por voto popular e este escolhido pela Assembléia da República e incumbido da chefia do Governo.

Nos termos do art. 105 da Constituição Portuguesa, o Orçamento do Estado contém a discriminação das receitas e despesas do Estado, incluindo as dos fundos e serviços autônomos e o orçamento da segurança social. Deve ser elaborado de forma harmônica com as grandes opções em matéria de planejamento (art. 105, 2) e pode ser estruturado por programas (art. 105, 3).

195 MABARAK CERECEDO, Doricela. Derecho Financiero Público. $3^{\mathrm{a}}$ ed. México: McGraw-Hill Interamericana, 2007, p. 44. 
A Lei de Orçamento deve ser elaborada, organizada, votada e executada de acordo com a Lei de Enquadramento Orçamental do Estado (Lei $\mathrm{n}^{\circ}$ 91/01, alterada pela Lei $\mathrm{n}^{\circ}$ 48/04), nos termos previstos pelo art. 106, 1, da Carta Portuguesa.

A atribuição conferida à Assembléia da República, relativamente à aprovação do Orçamento do Estado encontra-se prevista no art. 161 da Constituição. Os poderes da Assembléia da República, em matéria orçamentária, são amplos:

\begin{abstract}
A Assembleia da República detém poderes ilimitados para alterar a proposta orçamental do executivo, podendo aumentar a despesa ou reduzir a receita, sem se encontrar vinculada a qualquer regra restritiva durante o processo de alteração da proposta orçamental. Apesar disso, na prática, só um número reduzido de alterações foram aprovadas pela Assembleia da República, nestas condições, nos últimos anos. Isto devese, parcialmente, à tradição política portuguesa de conjugação de uma forte disciplina partidária com um governo majoritário ${ }^{196}$.
\end{abstract}

Por sua vez, o Executivo não possui poderes para vetar a alteração orçamental proposta pela Assembléia da República ${ }^{197}$.

Essa Assembléia encontra-se estruturada em doze Comissões, entre as quais a Comissão de Orçamento e Finanças, composta por dezenove deputados, que exercita prerrogativas de realização de audiências sobre as propostas de orçamento do governo, bem como de debate e votação do projeto e respectivas alterações ${ }^{198}$.

Em 2006, foi criada uma unidade especial de apoio à Comissão de Orçamento e Finanças, denominada UTAO. A UTAO é uma unidade independente composta por especialistas em direito e economia. Todavia, enfrenta dificuldades quanto ao quantitativo de especialistas, notoriamente reduzido ${ }^{199}$.

No mesmo ano, Portugal iniciou a sua primeira tentativa de implementação de um sistema de orçamentação baseada no desempenho para o conjunto da administração pública. Essa reforma foi iniciada pela Lei do Orçamento do Estado para 2006, onde se estipulou que a proposta de Orçamento de 2010 deveria apresentar uma estrutura de Programas ${ }^{200}$.

${ }^{196}$ PORTUGAL. MINISTÉRIO DAS FINANÇAS E DA ADMINISTRAÇÃO PÚBLICA. DIRECÇÃOGERAL DO ORÇAMENTO. Avaliação do Processo Orçamental em Portugal - Relatório da OCDE, p. 55. Disponível em: [http://www.dgo.pt/oe/OCDE2008/OCDE2008_AvaliacaoProcessoOrcamentalEmPortgual.pdf]. Acesso em 17.07.09. Texto originalmente publicado em língua inglesa pela OCDE com o título: Budgeting in Portugal por Teresa Curristine, Chung-Keun Park e Richard Emery, 2008.

${ }^{197}$ Ibid., p. 56.

${ }_{198}$ Ibid., p. 53.

${ }^{199}$ Ibid., p. 57.

${ }^{200}$ Ibid., p. 81. 
Posteriormente, em 2007, foi criada a Comissão para a Orçamentação por Programas, incumbida de efetuar recomendações a respeito da implementação da orçamentação por programas no país, inclusive no que se refere à avaliação de resultados. Outra importante iniciativa, no âmbito da reforma orçamentária, foi a edição, também em 2007, da legislação que instituiu o Sistema Integrado de Gestão e Avaliação do Desempenho na Administração Pública - SIADAP 201.

A análise do desempenho de cada organismo encontra-se baseada em um quadro de avaliação e responsabilização denominado $Q U A R$. Tal instrumento permite que seja avaliada a performance das entidades públicas - central, regional e local -. Cada organismo deve identificar os recursos disponíveis - humanos e financeiros -, desagregar os objetivos estratégicos em operacionais e destacar o progresso pretendido em termos de eficácia, eficiência e qualidade, além de definir indicadores de desempenho e metas para posterior aferição do progresso alcançado ${ }^{202}$.

A Lei de Enquadramento Orçamental do Estado - LEOE determina que a discussão e votação do Orçamento na Assembléia da República devem ser efetuadas no prazo de 45 dias e o orçamento deverá ser aprovado um mês antes do início do novo exercício financeiro.

Em conformidade com o art. 41 da LEOE, se o orçamento não for aprovado antes do início do novo ano, o orçamento do ano anterior deverá permanecer em vigor. Isso significa que o governo está autorizado a efetuar uma despesa mensal correspondente a 1/12 do orçamento do último exercício financeiro. A prorrogação da vigência da Lei de Orçamento é prevista da seguinte forma na LEOE:

Art. $41^{\circ}$ Prorrogação da vigência da lei do Orçamento 1 - A vigência da lei do Orçamento do Estado é prorrogada quando se verifique:

a) A rejeição da proposta de lei do Orçamento do Estado;

(...)

d) A não votação parlamentar da proposta de lei do Orçamento do Estado.

Adicionalmente, deve-se salientar que objetivos fiscais também encontram-se associados ao processo orçamentário. Nesse sentido, o objetivo de médio prazo do Governo atual é um déficit estrutural de $0,5 \%$ do PIB.

${ }^{201}$ PORTUGAL. MINISTÉRIO DAS FINANÇAS E DA ADMINISTRAÇÃO PÚBLICA. DIRECÇÃOGERAL DO ORÇAMENTO, op. cit., p. 93.

${ }^{202}$ Ibid., p. 93. 
O atual enquadramento jurídico do processo orçamentário português encontra-se baseado nos seguintes diplomas legais:

- Constituição Portuguesa de 1976;

- Lei de Bases da Contabilidade Pública de 1990;

- Lei de Enquadramento Orçamental do Estado de 2001, alterada em 2004;

- Leis das Finanças Locais e Regionais de 2007;

- Decretos-lei anuais de execução orçamental.

O setor público administrativo português reparte-se em três componentes principais: administração central; segurança social; e governos regionais e autarquias locais. A Segurança Social possui um orçamento próprio que, no entanto, faz parte do Orçamento do Estado.

Em Portugal, as funções relacionadas com o orçamento da administração central são da responsabilidade da Direcção-Geral do Orçamento - DGO do Ministério da Fazenda e Administração Pública - MFAP. Enquanto a DGO é responsável pela elaboração e execução detalhadas do orçamento, a responsabilidade pelas previsões macroeconômicas recai sobre o Gabinete de Planejamento, Estratégia, Avaliação e Relações Internacionais - GPEARI, também do MFAP.

Nos termos do art. 34 da Lei de Enquadramento Orçamental, a proposta de lei do Orçamento tem uma estrutura e um conteúdo formal idênticos aos da Lei do Orçamento, que se encontra estruturada em articulado e mapas orçamentais.

Os mapas orçamentais discriminam os limites de despesa para os ministérios e os cerca de seiscentos organismos públicos; por outro lado, os limites de despesa encontramse organizados em quatro categorias funcionais, desdobradas em dezesseis subcategorias, uma classificação econômica e categorias administrativas ${ }^{203}$.

Uma vez aprovada a Lei do Orçamento do Estado pela Assembléia da República, o governo emite no início do ano o Decreto-lei de execução orçamental, que estabelece as regras para a execução orçamental naquele exercício.

A LEOE determina que os orçamentos sejam sistematizados por objetivos, compatibilizados com os planos, em conformidade com as atividades desenvolvidas por cada organismo público, visando fundamentar as decisões alocativas. Nos termos do art. 15 do referido diploma legal, tem-se o que segue:

${ }^{203}$ PORTUGAL. MINISTÉRIO DAS FINANÇAS E DA ADMINISTRAÇÃO PÚBLICA. DIRECÇÃOGERAL DO ORÇAMENTO, op. cit., p. 35. 
Art. $15^{\circ}$ Gestão por objectivos

1 - Os orçamentos e contas dos organismos a que se refere o $n^{\circ} 1$ do artigo $2^{\circ}$ devem ser objecto de uma sistematização por objectivos, compatibilizada com os objectivos previstos nas Grandes Opções do Plano, considerando a definição das actividades a desenvolver por cada organismo e respectivos centros de custos e tendo em conta a totalidade dos recursos envolvidos, incluindo os de capital, visando fundamentar as decisões sobre a reorientação e o controlo da despesa pública:

a) No conhecimento da missão, objectivos e estratégia do organismo;

b) $\quad \mathrm{Na}$ correcta articulação de cada área de actividade em relação aos objectivos;

c) Na responsabilização dos agentes empenhados na gestão das actividades pela concretização dos objectivos e bom uso dos recursos que lhes estão afectos;

d) $\quad \mathrm{Na}$ identificação de actividades redundantes na cadeia de valor do organismo a justificada reafectação dos recursos nelas consumidos.

2 - Os desenvolvimentos orçamentais referidos no $\mathrm{n}^{\circ} 1$ obedecem à estruturação por programas prevista na presente lei.

Em consonância ao disposto no art. 105, 3, da Constituição Portuguesa, consta do art. 18 da LEOE a exigência de que o Orçamento do Estado seja estruturado por programas:

\footnotetext{
Artigo $18^{\circ}$

1 - Sem prejuízo da sua especificação de acordo com as classificações orgânica, funcional e económica, as despesas inscritas nos orçamentos que integram o Orçamento do Estado podem estruturar-se, no todo ou em parte, por programas, nos termos previstos na presente lei.

2 - Com o objectivo de racionalizar a preparação e reforçar o controlo da gestão e da execução orçamental, o orçamento deve ser estruturado por programas, medidas e projectos ou actividades. (g.n.)
}

A estruturação dos orçamentos por programas é uma concepção moderna do processo orçamentário, em sintonia com as recentes tendências mundiais, e encontra-se tradicionalmente conectada à concepção de orçamento por desempenho - performance budget -. Em outras palavras:

\begin{abstract}
Um orçamento por programas é uma forma de estruturação do orçamento. O orçamento pode ser organizado de acordo com os bens e serviços produzidos, ou em programas. As dotações de um determinado programa caracterizam-se por terem subjacentes objectivos relacionados uns com os outros, ou por partilharem um mesmo objectivo final, e servem para financiar todas as actividades relacionadas com a produção de bens e serviços no âmbito do programa em questão $0^{204}$.
\end{abstract}

A definição de programas e respectivos elementos integrantes está fixada no art. 19 da Lei de Enquadramento Orçamental portuguesa, nos termos seguintes:

${ }^{204}$ PORTUGAL. MINISTÉRIO DAS FINANÇAS E DA ADMINISTRAÇÃO PÚBLICA. DIRECÇÃOGERAL DO ORÇAMENTO, op. cit., p. 77. 
Artigo $19^{\circ}$ Programas orçamentais

1 - O programa orçamental inclui as despesas correspondentes a um conjunto de medidas de carácter plurianual que concorrem, de forma articulada e complementar, para a concretização de um ou vários objectivos específicos, relativos a uma ou mais políticas públicas, dele fazendo necessariamente parte integrante um conjunto de indicadores que permitam avaliar a economia, a eficiência e a eficácia da sua realização. (...)

4 - Cada programa orçamental divide-se em medidas, podendo existir programas com uma única medida.

Portanto, aos programas devem ser associados objetivos específicos, medidas integrantes e o conjunto de indicadores de desempenho que permitam a avaliação da economia, eficiência e eficácia no uso dos recursos orçamentários. Além disso, a informação sobre o desempenho permite que os governos meçam os progressos alcançados no sentido de se atingir os objetivos das suas políticas e dos seus programas.

Por sua vez, o tratamento das medidas, ou conjunto de ações que integra um determinado programa, é feito no artigo seguinte:

\footnotetext{
Art. $20^{\circ}$ Medidas

1 - A medida compreende despesas de um programa orçamental correspondente a projectos ou actividades, bem especificados e caracterizados, que se articulam e complementam entre si e concorrem para a concretização dos objectivos do programa em que se inserem.

(...)

3 - Cada medida divide-se em projectos ou actividades, podendo existir medidas com um único projecto ou actividade.
}

Nota-se que o ordenamento jurídico português, antes mesmo da efetiva implementação da orientação orçamentária baseada no desempenho, já imprimia tais vetores ao processo orçamentário. Tradicionalmente, o sistema orçamentário português encontrava-se fundamentado em um controle estrito de conformidade legal, apresentando um delineamento inflexível e incremental ${ }^{205}$.

Tal orientação, contudo, está em processo de modificação, conforme destacam Curristine, Park e Emery, ao analisarem o trâmite orçamentário português, nos seguintes excertos:

(...) o processo orçamental tem sido alterado de forma significativa, com o objectivo de melhorar a disciplina orçamental e a eficiência e eficácia da despesa pública. Pretendese evoluir de uma concepção predominantemente centrada na conformidade legal e no controlo detalhado da despesa para um sistema mais flexível e orientado para o desempenho ${ }^{206}$.

${ }^{205}$ PORTUGAL. MINISTÉRIO DAS FINANÇAS E DA ADMINISTRAÇÃO PÚBLICA. DIRECÇÃOGERAL DO ORÇAMENTO, op. cit., p. 32.

${ }^{206}$ Ibid., p. 09. 
A proposta de adoptar um modelo de Orçamentação por Programas aumentará a transparência. Focar em programas, ao invés de em 5.000 linhas do orçamento, aumentará a percepção dos cidadãos relativamente à forma como estão a ser utilizados os dinheiros públicos. Reduzir o detalhe excessivo do orçamento não implica um menor controlo orçamental. Pelo contrário, um orçamento por programas tornará mais fácil compreender o orçamento, discutir as propostas orçamentais e gerar consenso sobre a política orçamental. (...)

A transição para um orçamento por programas orientado para o desempenho irá requerer a delegação de responsabilidades orçamentais aos ministérios e/ou gestores de programas. A redução do número de linhas do orçamento deverá reduzir a necessidade de controlo detalhado pela DGO e aumentará a flexibilidade dos gestores de programas. Os ministérios, e em particular os organismos públicos, deverão ter a responsabilidade primária pela execução orçamental e pela gestão dos programas. O controlo detalhado das alterações orçamentais deve ser fortemente reduzido, na medida em que os gestores dos programas assumam a responsabilidade por desvios na despesa, e em que as dotações orçamentais passem a estar estruturadas em programas. Esta evolução implica uma profunda revisão dos processos de gestão financeira do sector público ${ }^{207}$.

A Lei de Enquadramento Orçamental do Estado referendou, indiretamente, a clássica diferenciação entre despesas obrigatórias e despesas discricionárias. Em seu art. 16 tratou das despesas obrigatórias, determinando a inscrição no Orçamento do Estado: i) das dotações necessárias ao cumprimento das obrigações decorrentes de lei ou de contrato; ii) das dotações destinadas ao pagamento de encargos resultantes de sentenças de quaisquer tribunais; e iii) de outras dotações determinadas por lei.

$\mathrm{O}$ art. 42 da LEOE tratou dos princípios norteadores da execução orçamentária, destacando que "as dotações constantes do orçamento das despesas constituem o limite máximo a utilizar na realização destas" (art. 42, 5) e que nenhuma despesa poderia ser autorizada ou paga sem que satisfizesse os princípios de economia, eficiência e eficácia (art. 42, 6, 'a').

Para assegurar o controle das dotações orçamentárias, há dois mecanismos presentes no ordenamento português, quais sejam, o congelamento e o sistema de duodécimos. Como afirmam Curristine, Park e Emery:

Portugal implementou dois mecanismos para assegurar o controlo orçamental. O primeiro consiste no 'congelamento' de determinadas verbas do orçamento: uma percentagem de certas categorias de despesas não obrigatórias pode ser congelada no início do ano orçamental, por exemplo, o valor global da dotação pode ser congelado numa reserva de $15 \%$, o que se traduz numa dotação líquida de $85 \%$ do valor original aprovado. O segundo mecanismo é o chamado 'sistema de duodécimos'. Este mecanismo permite a execução gradual das despesas de modo a garantir que estas são distribuídas pelo ano do orçamento. Em regra, um duodécimo da dotação líquida de congelamentos é afecto à despesa a realizar em cada mês ${ }^{208}$.

${ }^{207}$ PORTUGAL. MINISTÉRIO DAS FINANÇAS E DA ADMINISTRAÇÃO PÚBLICA. DIRECÇÃOGERAL DO ORÇAMENTO, op. cit., p. 12/14.

${ }^{208}$ Ibid., p. 63. 
Existe certa flexibilidade no ordenamento português, relativamente a mudanças das dotações de despesa $^{209}$. O próprio texto constitucional português faz menção à possibilidade de alterações no Orçamento durante a execução orçamentária, que poderão ser introduzidas de acordo com as regras estabelecidas em lei (art. 105, 4).

Coube à Lei de Enquadramento Orçamental a regulamentação do dispositivo constitucional, o que é feito por meio dos arts. 51, 53 e 54, a seguir transcritos, que discriminam, de forma geral, as modificações que competem ao Governo e aquelas que se encontram na esfera de atribuições da Assembléia:

Artigo $51^{\circ}$ Alterações orçamentais da competência do Governo

(...)

2 - O Governo pode reduzir ou anular quaisquer dotações orçamentais que careçam de justificação, desde que fiquem salvaguardadas as obrigações do Estado decorrentes de lei ou de contrato.

(...)

4 - As alterações orçamentais que, nos termos da presente lei, sejam da competência do Governo podem também ser efectuadas pelos dirigentes dos serviços sob a sua direcção ou tutela, nos casos previstos no decreto-lei a que se refere o número anterior.

Artigo $54^{\circ}$

1 - Competem à Assembleia da República as alterações orçamentais que consistam na inscrição de novos programas.

2 - Competem à Assembleia da República as alterações orçamentais que consistam num aumento do montante total das despesas de cada programa, salvo o disposto no número seguinte.

3 - Competem ao Governo as alterações orçamentais a que se refere o número anterior, nos casos em que o aumento do montante total das despesas de cada programa tenha contrapartida:

a) Em aumento da previsão de receitas efectivas que estejam consignadas;

b) Em saldos de gerência ou de dotações de anos anteriores cuja utilização seja permitida por lei;

c) $\quad \mathrm{Na}$ dotação provisional.

(...)

5 - São da competência do Governo as transferências de verbas:

a) Entre programas, desde que com o mesmo título e capítulo e se se mantiver a respectiva classificação funcional;

b) Entre as diversas medidas, projectos ou actividades num mesmo programa;
c) (...)
d) (...)

Uma breve síntese acerca das possibilidades de alteração previstas na legislação portuguesa é feita pelos analistas da Organização para a Cooperação e Desenvolvimento Econômico - OCDE, como se segue:

${ }^{209}$ PORTUGAL. MINISTÉRIO DAS FINANÇAS E DA ADMINISTRAÇÃO PÚBLICA. DIRECÇÃOGERAL DO ORÇAMENTO, op. cit., p. 64. 
O valor global de cada capítulo orgânico não pode ser excedido a não ser que uma das seguintes situações se verifique: um organismo gere uma receita própria superior ao previsto; a legislação permita que os saldos transitem do ano precedente; outro organismo do mesmo ministério, ou outro ministério no contexto do mesmo programa orçamental, transfira fundos orçamentados; ou o MFAP autorize um aumento do limite superior da despesa, financiado por uma transferência da dotação provisional. Podem também ocorrer reafectações entre diferentes rubricas do orçamento do serviço, ou entre subdivisões orçamentais. Estas reafectações podem verificar-se entre organismos que se encontrem sob o mesmo capítulo orgânico, desde que a categoria funcional implícita ao orçamento se mantenha inalterada. Todas estas regras estão especificadas na legislação, principalmente na Lei de Enquadramento Orçamental de 2001; num Decreto-lei de 1995 sobre alterações orçamentais da competência do governo, no Decreto-lei de execução do orçamento anual e em Circulares da $\mathrm{DGO}^{210}$.

No caso em que alterações orçamentárias não são possíveis e quando não existe disponibilidade de fundos na dotação provisional, somente poderá haver aumento de despesa caso seja aprovado um orçamento retificativo ${ }^{211}$.

Por sua vez, relativamente à fiscalização da execução do Orçamento, o art. 107 da Carta Magna Portuguesa determina que tal tarefa incumbe ao Tribunal de Contas e à Assembléia da República. Já o art. 58 da LEOE trata do controle orçamentário, estabelecendo que a execução do Orçamento fica sujeita a controle que tem por objeto a verificação da legalidade e da regularidade financeira das receitas e das despesas públicas, bem como a apreciação da boa gestão dos dinheiros públicos.

\subsection{O Orçamento no ordenamento jurídico francês}

A Constituição francesa de 1958 assegura ao Executivo extensos poderes em matéria orçamentária. Prevê limitações à atuação do Parlamento ${ }^{212}$, circunscrevendo-a a alterações na composição das despesas constantes do orçamento, visto que o Poder

\footnotetext{
${ }^{210}$ PORTUGAL. MINISTÉRIO DAS FINANÇAS E DA ADMINISTRAÇÃO PÚBLICA. DIRECÇÃOGERAL DO ORÇAMENTO, op. cit., p. 64.

${ }^{211}$ Ibid., p. 65.

${ }^{212}$ Nos termos do artigo 40 da Constituição francesa, as proposições e emendas formuladas pelos membros do Parlamento não serão recebidas no caso em que acarretem uma diminuição das receitas públicas, ou ainda no caso de criação ou aumento de despesas públicas. Confira-se a redação original do texto francês: "Article 40. Les propositions et amendements formulés par les membres du Parlement ne sont pas recevables lorsque leur adoption aurait pour conséquence soit une diminution des ressources publiques, soit la création ou l'aggravation d'une charge publique".
} 
Legislativo não pode aumentar o total de gastos ou diminuir as receitas previstas no orçamento $^{213}$.

Ademais, mesmo se o Parlamento propuser emendas, poderá o primeiro-ministro forçar a aprovação da sua própria versão de proposta de lei orçamentária, procedimento este que somente será obstaculizado por meio de uma moção de censura, com a consequente queda do Gabinete ${ }^{214}$.

A principal lei que regula o procedimento orçamentário no ordenamento jurídico francês é a Lei Orgânica das Leis de Finanças - LOLF, de agosto de 2001, prevista constitucionalmente. Na França, depois da publicação da LOLF, opera-se uma grande mudança na preparação e execução orçamentárias, com ênfase em um maior controle do Parlamento sobre as despesas públicas e a ênfase em uma cultura de transparência sincérité -, de resultados e de performance. Uma das premissas é a desconcentração e a descentralização da gestão, procurando-se responsabilizar os gestores públicos pela execução dos programas $^{215}$.

Os principais objetivos da LOLF foram ${ }^{216}$ :

1. modernização do modelo orçamentário, por meio de uma apresentação de orçamento por missões e programas, por meio dos quais são estabelecidos objetivos e indicadores de resultados. Nesse sentido, visa-se modificar a orientação orçamentária prevalescente: de um orçamento incremental orientado para insumos a um orçamento orientado para resultados; e

2. aumento dos poderes parlamentares em matéria orçamentária e ampliação da accountability. Para tais fins, amplia-se a submissão de relatórios e informações

\footnotetext{
${ }^{213}$ O Jornal de Orçamento da OCDE tece considerações no mesmo sentido: "The Constitution does not allow Parliament to propose any amendments (to any law) that would create new expenditures, raise total State expenditure (charges) or lower revenues (ressources). Parliament may only alter the composition of proposed State budget spending, by changing the amount allocated to programmes within missions (...). Even if Parliament proposes amendments, another constitutional provision allows the government to force throught its own version of the budget". OECD Journal on Budgeting. Special Issue. The Legal Framework for Budget Systems - An Internacional Comparison. V. 4, n. 3, 2004, p. 201. Disponível em [http://www..oecd.org/dataoecd/48/48/35933542.pdf]. Acesso em 30.06.2009.

${ }^{214}$ Nos termos da redação da Constituição francesa: "Article 49. (...) Le Premier Ministre peut, après délibération du Conseil des Ministres, engager la responsabilité du Gouvernement devant l'Assemblée Nationale sur le vote d'un projet de loi de finances ou de financement de la sécurité sociale. Dans ce cas, ce projet est considéré comme adopté, sauf si une motion de censure, déposée dans les vingt-quatre heures qui suivent, est votée dans les conditions prévues à l'alinéa précédent. Le Premier ministre peut, en outre, recourir à cette procédure pour un autre projet ou une proposition de loi par session (...)”.

${ }^{215}$ ALMEIDA, António Júlio; NEROSKY, Luiz Carlos. Diagnóstico do Processo Orçamentário Federal e Propostas de Medidas de Reforma - Modelos Orçamentários em outros Países. Ministério do Planejamento - Secretaria de Orçamento Federal. Brasília, maio/junho 2006, p. 37/38. Disponível em [https://www.portalsof.planejamento.gov.br/bib/Estudos/Modelos_Orcamentarios_em_Outros_Paises.pdf]. Acesso em 20.05.2009.

${ }^{216}$ OECD Journal on Budgeting. Special Issue, op. cit., p. 188.
} 
orçamentárias ao Parlamento; em particular, devem ser encaminhados relatórios anuais nos quais se apreciam os resultados dos programas previstos na peça orçamentária, confrontando-os com os fins inicialmente estabelecidos.

Efetivamente, a LOLF determina que as leis de finanças, entre as quais figura a lei orçamentária, incorporem objetivos e resultados dos programas estipulados ${ }^{217}$. Além disso, deve acompanhar a lei orçamentária um anexo contendo um relatório de estratégia fiscal, bem como informação relativa à performance, com a lista de missões e programas, incluindo indicadores de desempenho dos programas, inclusive para o exercício financeiro seguinte. Acrescente-se, ainda, a necessidade de planos de desempenho para cada programa, incluindo objetivos, custos, resultados atingidos e resultados esperados, de acordo com os indicadores escolhidos ${ }^{218}$.

No modelo francês, a estrutura de créditos orçamentários encontra-se orientada pelo princípio da fungibilidade ${ }^{219}$, permitindo ao gestor total poder quanto ao gerenciamento dos créditos atribuídos ao programa. Nesse sentido, os gestores podem, dentro do programa, transferir recursos de um projeto para outro, ou de um item de despesa para outro, sem necessidade de solicitar autorização do Parlamento ${ }^{220}$. Todavia, tal flexibilidade

217 “Article 1. Dans les conditions et sous les reserves prévues par la présente loi organique, les lois de finances déterminent, pour un exercice, la nature, le montant et l'affectation des ressources et des charges de l'Etat, ainsi que l'équilibre budgétaire et financier qui en résulte. Elles tiennent compte d'un équilibre économique definí, ainsi que des objectifs et des résultats des programmes qu'elles déterminent" (g.n.).

${ }^{218}$ Nos exatos termos dos artigos 48 e 51 da LOLF: "Article 48. En vue de l'examen et du vote du projet de loi de finances de l'année suivante par le Parlement, le Gouvernement présente, au cours du dernier trimestre de la session ordinaire, un rapport sur l'évolution de l'économie nationale et sur les orientations des finances publiques comportant : (...) $4^{\circ}$ La liste des missions, des programmes et des indicateurs de performances associés à chacun de ces programmes, envisagés pour le projet de loi de finances de l'année suivante".

"Article 51. Sont joints au projet de loi de finances de l'année : (...)

$4^{\circ}$ bis Une présentation des mesures envisagées pour assurer en exécution le respect du plafond global des dépenses du budget général voté par le Parlement, indiquant en particulier, pour les programmes dotés de crédits limitatifs, le taux de mise en réserve prévu pour les crédits ouverts sur le titre des dépenses de personnel et celui prévu pour les crédits ouverts sur les autres titres ;

$5^{\circ}$ Des annexes explicatives développant conformément aux dispositions de l'article 5, pour l'année en cours et l'année considérée, par programme ou par dotation, le montant des crédits présentés par titre et présentant, dans les mêmes conditions, une estimation des crédits susceptibles d'être ouverts par voie de fonds de concours. Ces annexes sont accompagnées du projet annuel de performances de chaque programme précisant: a) La présentation des actions, des coûts associés, des objectifs poursuivis, des résultats obtenus et attendus pour les années à venir mesurés au moyen d'indicateurs précis dont le choix est justifié ; b) L'évaluation des dépenses fiscales ; c) La justification de l'évolution des crédits par rapport aux dépenses effectives de l'année antérieure, aux crédits ouverts par la loi de finances de l'année en cours et à ces mêmes crédits éventuellement majorés des crédits reportés de l'année précédente, en indiquant leurs perspectives d'évolution ultérieure; (...)".

${ }^{219}$ ALMEIDA, António Júlio; NEROSKY, Luiz Carlos, op. cit., p. 38.

220 “(...) budget programme managers will be responsible for preparing ex ante and ex post performance indicators for their programmes and contributing to annual reports". Cf. OECD Journal on Budgeting. Special Issue, op. cit., p. 190. 
possui restrições, a exemplo da vedação de se exceder o volume previsto para as despesas com pessoal ou a transferência de recursos de investimento para despesas correntes ${ }^{221}$.

A proposta de lei orçamentária é votada em duas partes: na primeira, o Parlamento aprova as receitas e a autorização do total das despesas; na segunda, são feitos os detalhamentos das programações orçamentárias ${ }^{222}$. Nesse modelo, a lei orçamentária incorpora a autorização para o recebimento dos impostos e demais receitas públicas; desse modo, existe a necessidade de renovação desse consentimento a cada ano, por meio de um voto do Parlamento na primeira parte do Orçamento do Estado ${ }^{223}$.

Nos termos do art. $7^{\circ}$ da LOLF, os créditos orçamentários são agrupados por missões, e cada missão compreende o conjunto de programas concorrentes para uma política pública definida ${ }^{224}$. Aos programas são associados objetivos precisos, bem como resultados esperados e submetidos à avaliação ${ }^{225}$.

Os créditos são especificados por programas ou por dotação, e os créditos de um programa ou dotação são apresentados segundo os títulos constantes do art. $5^{\circ}$ da LOLF. A indicação dos créditos por título é indicativa. Entretanto, os créditos abertos no título das despesas de pessoal de cada programa constituem um teto das despesas dessa natureza ${ }^{226}$.

Em se tratando do art. $5^{\circ}$ da LOLF, este discrimina sete títulos sob os quais se agrupam os encargos orçamentários, quais sejam: dotações dos poderes públicos; despesas

\footnotetext{
${ }^{221}$ ALMEIDA, António Júlio; NEROSKY, Luiz Carlos, op. cit., p. 38.

${ }^{222}$ Nos termos dos dispositivos da LOLF: “Article 34. La loi de finances de l'année comprend deux parties distinctes. I. - Dans la première partie, la loi de finances de l'année : $1^{\circ}$ Autorise, pour l'année, la perception des ressources de l'Etat et des impositions de toute nature affectées à des personnes morales autres que l'Etat ; (...) $6^{\circ}$ Fixe les plafonds des dépenses du budget général et de chaque budget annexe, les plafonds des charges de chaque catégorie de comptes spéciaux ainsi que le plafond d'autorisation des emplois rémunérés par l'Etat; (...) II. - Dans la seconde partie, la loi de finances de l'année: $1^{\circ}$ Fixe, pour le budget général, par mission, le montant des autorisations d'engagement et des crédits de paiement ; $2^{\circ}$ Fixe, par ministère et par budget annexe, le plafond des autorisations d'emplois; (...)

Article 42. La seconde partie du projet de loi de finances de l'année et, s'il y a lieu, des projets de loi de finances rectificative, ne peut être mise en discussion devant une assemblée avant l'adoption de la première partie".

${ }^{223}$ OECD Journal on Budgeting. Special Issue, op. cit., p. 201.

224 "Article 7. Les crédits ouverts par les lois de finances pour couvrir chacune des charges budgétaires de l'Etat sont regroupés par mission relevant d'un ou plusieurs services d'un ou plusieurs ministères. Une mission comprend un ensemble de programmes concourant à une politique publique définie. Seule une disposition de loi de finances d'initiative gouvernementale peut creer une mission (...)".

225 “Article 7. (...) Un programme regroupe les crédits destinés à mettre en oeuvre une action ou un ensemble cohérent d'actions relevant d'un même ministère et auquel sont associés des objectifs précis, définís en fonction de finalités d'intérêt general, ainsi que des résultats attendus et faisant l'objet d'une évaluation (...)". 226 “Article 7. (...) La présentation des crédits par titre est indicative. Toutefois, les crédits ouverts sur le titre des dépenses de personnel de chaque programme constituent le plafond des dépenses de cette nature".
} 
de pessoal; despesas de funcionamento; encargos da dívida; despesas de investimento; despesas de intervenção; e despesas de operações financeiras ${ }^{227}$.

Conforme dispõe o art. $8^{\circ}$ da LOLF, os créditos abertos são constituídos de autorização de comprometimento e de pagamento ${ }^{228}$. Consta do art. $9^{\circ}$ que os créditos são limitativos - les crédits sont limitatifs -, à exceção dos créditos relativos aos encargos da dívida do Estado e garantias concedidas pelo Estado, que têm caráter estimativo $^{229}$. Às despesas relativas a créditos de caráter estimativo podem ser consignados aportes complementares em caso de necessidade, devendo o Ministro das Finanças informar às Comissões da Assembléia e do Senado os motivos do excesso e perspectivas de execução até o final do exercício ${ }^{230}$.

Em princípio, a lei de orçamento somente pode ser modificada por meio de leis retificadoras, que possuem a mesma natureza e caráter de leis de finanças. Tais leis retificadoras podem modificar os montantes inicialmente previstos na lei orçamentária, além de ratificar alterações permitidas pela LOLF por meio de decreto do Poder Executivo $^{231}$. Não há limite quanto ao número de leis retificadoras da lei orçamentária que podem ser editadas em cada exercício ${ }^{232}$.

Todavia, a par das leis retificadoras do Orçamento, a LOLF contempla a permissão de eventuais modificações da lei orçamentária, sob certas circunstâncias, as quais são implementadas por decreto do Poder Executivo. Nesse sentido, faculta-se que decreto do Executivo cancele dotações no caso de queda de $\operatorname{arrecadação~}^{233}$, aumente dotações em caso

\footnotetext{
227 "Les charges budgétaires de l'Etat sont regroupées sous les titres suivants: $1^{\circ}$ Les dotations des pouvoirs publics; $2^{\circ}$ Les dépenses de personnel; $3^{\circ}$ Les dépenses de fonctionnement; $4^{\circ}$ Les charges de la dette de l'Etat; $5^{\circ}$ Les dépenses d'investissement; $6^{\circ}$ Les dépenses d'intervention; $7^{\circ}$ Les dépenses d'opérations financiéres".

228 "Article 8. Les crédits ouverts sont constitués d'autorisations d'engagement et de crédits de paiement (...)".

229 "Article 10. Les crédits relatifs aux charges de la dette de l'Etat (...) ont un caractère évaluatif. (...)”.

230 “Article 10. (...) Les dépenses auxquelles s'appliquent les crédits évaluatifs s'imputent, si nécessaire, audelà des crédits ouverts. Dans cette hypothèse, le minister chargé des finances informe les commissions de l'Assemblée nationale et du Sénat chargées des finances des motifs du dépassement et des perspectives d'exécution jusqu'à la fin de l'année".

231 “Article 35. Sous réserve des exceptions prévues par la présente loi organique, seules les lois de finances rectificatives peuvent, en cours d'année, modifier les dispositions de la loi de finances de l'année prévues aux $1^{\circ}$ et $3^{\circ}$ à $10^{\circ}$ du I et au $1^{\circ}$ à $6^{\circ}$ du II de l'article 34 . Le cas échéant, elles ratifient les modifications apportées par décret d'avance aux crédits ouverts par la dernière loi de finances".

232 "The LOLF does not limit the number of annual rectifying laws. Normally, at least on rectifying law is adopted each year and at times several more are enacted, especially when there is a change in the governing majority". Cf. OECD Journal on Budgeting. Special Issue, op. cit., p. 203/205.

233 "Article 14. I - Afin de prévenir une détérioration de l'équilibre budgétaire défini par la dernière loi de finances afférente à l'année concernée, un crédit peut être annulé par décret pris sur le rapport du ministre chargé des finances. Un crédit devenu sans objet peut être annulé par un décret pris dans les mêmes conditions. Avant sa publication, tout décret d'annulation est transmis pour information aux commissions de l'Assemblée nationale et du Sénat chargées des finances et aux autres commissions concernées. Le montant
} 
de urgência ${ }^{234}$ e suplemente outras em caso de 'necessidade imperiosa de interesse nacional $^{\text {,235 }}$, bem como fixe a destinação dos recursos consignados a título da 'reserva de contingência $^{236}$. Nesses casos, o Parlamento deve ser informado das modificações levadas a efeito pelo Executivo.

A LOLF ainda prevê a possibilidade de modificação da repartição dos créditos atribuídos a programas no âmbito de um mesmo Ministério - virements -, dentro do limite de $2 \%$ dos créditos abertos pela lei de finanças do ano para cada um dos programas envolvidos. Também são permitidas transferências - transfers - de créditos entre programas de Ministérios distintos, relacionadas a ações do programa de origem ${ }^{237}$. As alterações efetuadas no Orçamento por meio dos referidos institutos - virements/transfers também se concretizam por intermédio de decretos do Poder Executivo, após feita a comunicação das mudanças ao Parlamento.

Uma das inovações da LOLF é a necessidade de o Executivo prover o Poder Legislativo com uma série de relatórios concernentes à execução orçamentária. Nesse sentido, deve ser elaborada, anualmente, uma Lei de Prestação de Contas (loi de

cumulé des crédits annulés par décret en vertu du présent article et de l'article 13 ne peut dépasser $1,5 \%$ des crédits ouverts par les lois de finances afférentes à l'année en cours (...)”.

234 "Article 13. En cas d'urgence, des décrets d'avance pris sur avis du Conseil d'Etat et après avis des commissions de l'Assemblée nationale et du Sénat chargées des finances peuvent ouvrir des crédits supplémentaires sans affecter l'équilibre budgétaire défini par la dernière loi de finances. A cette fin, les décrets d'avance procèdent à l'annulation de crédits ou constatent des recettes supplémentaires. Le montant cumulé des crédits ainsi ouverts ne peut excéder $1 \%$ des crédits ouverts par la loi de finances de l'année".

235 "Article 13. (...) En cas d'urgence et de nécessité impérieuse d'intérêt national, des crédits supplémentaires peuvent être ouverts, après information des commissions de l'Assemblée nationale et du Sénat chargées des finances, par décret d'avance pris en Conseil des ministres sur avis du Conseil d'Etat. Un projet de loi de finances portant ratification de ces crédits est déposé immédiatement ou à l'ouverture de la plus prochaine session du Parlement".

236 "Article 11. En tant que de besoin, les crédits ouverts sur la dotation pour dépenses accidentelles et imprévisibles sont répartis par programme, par décret pris sur le rapport du ministre chargé des finances (...)".

237 "Article 12. I - Des virements peuvent modifier la répartition des crédits entre programmes d'un même ministère. Le montant cumulé, au cours d'une même année, des crédits ayant fait l'objet de virements, ne peut excéder $2 \%$ des crédits ouverts par la loi de finances de l'année pour chacun des programmes concernés. Ce plafond s'applique également aux crédits ouverts sur le titre des dépenses de personnel pour chacun des programmes concernés.

II - Des transferts peuvent modifier la répartition des crédits entre programmes de ministères distincts, dans la mesure où l'emploi des crédits ainsi transférés, pour un objet déterminé, correspond à des actions du programme d'origine. Ces transferts peuvent être assortis de modifications de la répartition des emplois autorisés entre les ministères concernés.

III - Les virements et transferts sont effectués par décret pris sur le rapport du ministre chargé des finances, après information des commissions de l'Assemblée nationale et du Sénat chargées des finances et des autres commissions concernées. L'utilisation des crédits virés ou transférés donne lieu à l'établissement d'un compte rendu spécial, inséré au rapport établi en application du $4^{\circ}$ de l'article 54.

IV - Aucun virement ni transfert ne peut être effectué au profit de programmes non prévus par une loi de finances.

Aucun virement ni transfert ne peut être effectué au profit du titre des dépenses de personnel à partir d'un autre titre". 
règlement), que apresenta o montante definitivo das receitas e despesas do orçamento, ratifica modificações efetuadas na lei orçamentária, atualiza as apropriações orçamentárias nos casos em que tenha havido extrapolação e cancela apropriações não gastas ${ }^{238}$.

Deve acompanhar a Lei de Prestação de Contas um anexo contendo o montante definitivo dos créditos abertos por programa ou dotação e as despesas efetivamente realizadas, com indicação das variações ocorridas, bem como um anexo explicativo que apresente as justificativas para a não utilização dos créditos orçamentários inicialmente previstos para cada programa.

Também são necessários relatórios anuais de performance que evidenciem as variações ocorridas em relação às previsões iniciais da Lei de Orçamento, resultados esperados e obtidos dos programas, além de indicadores e custos associados ${ }^{239}$. ${ }^{238}$ Nos termos do art. 37 da LOLF: “Article 37. I - La loi de règlement arrête le montant définitif des recettes
et des dépenses du budget auquel elle se rapporte, ainsi que le résultat budgétaire qui en découle.
II - La loi de règlement arrête le montant définitif des ressources et des charges de trésorerie ayant concouru
à la réalisation de l'équilibre financier de l'année correspondante, présenté dans un tableau de financement.
III - La loi de règlement approuve le compte de résultat de l'exercice, établi à partir des ressources et des
charges constatées dans les conditions prévues à l'article 30 . Elle affecte au bilan le résultat comptable de
l'exercice et approuve le bilan après affectation ainsi que ses annexes.

IV - Le cas échéant, la loi de règlement :

$1^{\circ}$ Ratifie les modifications apportées par décret d'avance aux crédits ouverts par la dernière loi de finances afférente à cette année ;

$2^{\circ}$ Ouvre, pour chaque programme ou dotation concerné, les crédits nécessaires pour régulariser les dépassements constatés résultant de circonstances de force majeure dûment justifiées et procède à l'annulation des crédits n'ayant été ni consommés ni reportés ;

$3^{\circ}$ Majore, pour chaque compte spécial concerné, le montant du découvert autorisé au niveau du découvert constaté ;

$4^{\circ}$ Arrête les soldes des comptes spéciaux non reportés sur l'exercice suivant;

$5^{\circ}$ Apure les profits et pertes survenus sur chaque compte spécial.

$\mathrm{V}$ - La loi de règlement peut également comporter toutes dispositions relatives à l'information et au contrôle du Parlement sur la gestion des finances publiques, ainsi qu'à la comptabilité de l'Etat et au régime de la responsabilité pécuniaire des agents des services publics".

${ }^{239}$ Nos exatos termos em que a Lei de Finanças francesa dispõe:

"Article 54. Sont joints au projet de loi de règlement :

$1^{\circ}$ Le développement des recettes du budget général ;

$2^{\circ}$ Des annexes explicatives, développant, par programme ou par dotation, le montant définitif des crédits ouverts et des dépenses constatées, en indiquant les écarts avec la présentation par titre des crédits ouverts, et les modifications de crédits demandées. Elles présentent également l'écart entre les estimations et les réalisations au titre des fonds de concours ;

$3^{\circ}$ Une annexe explicative présentant les recettes et les dépenses effectives du budget de l'Etat selon les conventions prévues au $3^{\circ}$ de l'article 51 et comportant pour chaque programme, les justifications des circonstances ayant conduit à ne pas engager les dépenses correspondant aux crédits destinés à financer les dépenses visées au $5^{\circ}$ du I de l'article 5 ;

$4^{\circ}$ Les rapports annuels de performances, faisant connaître, par programme, en mettant en évidence les écarts avec les prévisions des lois de finances de l'année considérée, ainsi qu'avec les réalisations constatées dans la dernière loi de règlement :

a) Les objectifs, les résultats attendus et obtenus, les indicateurs et les coûts associés ;

b) La justification, pour chaque titre, des mouvements de crédits et des dépenses constatées, en précisant, le cas échéant, l'origine des dépassements de crédits exceptionnellement constatés pour cause de force majeure ; c) La gestion des autorisations d'emplois, en précisant, d'une part, la répartition des emplois effectifs selon les modalités prévues au e du $5^{\circ}$ de l'article 51 , ainsi que les coûts correspondants et, d'autre part, les mesures 
Percebe-se que o sistema orçamentário francês inclina-se decisivamente no sentido da implementação do Orçamento de Desempenho - performance-based budget -, somando a concessão de flexibilidade gerencial à cobrança de resultados, além de diversas exigências da LOLF para o Executivo prover o Parlamento com informações detalhadas relativas à execução das missões e programas previamente fixados no Orçamento do Estado. O modelo francês é, atualmente, uma das grandes referências mundiais em termos de Orçamento.

justifiant la variation du nombre des emplois présentés selon les mêmes modalités ainsi que les coûts associés à ces mesures;

d) La présentation des emplois effectivement rémunérés par les organismes bénéficiaires d'une subvention pour charges de service public prévue au II de l'article 5 ;

$5^{\circ}$ Des annexes explicatives développant, par programme ou par dotation, pour chaque budget annexe et chaque compte spécial, le montant définitif des recettes et des dépenses constatées, des crédits ouverts ou du découvert autorisé, ainsi que les modifications de crédits ou de découvert démandées, Ces annexes sont accompagnées du rapport annuel de performances de chacun d'entre eux, dans les conditions prévues au $4^{\circ}$; $6^{\circ}$ Des annexes explicatives présentant les résultats de la comptabilité selon les dispositions prévues au deuxième alinéa de l'article 27 ;

$7^{\circ}$ Le compte général de l'Etat, qui comprend la balance générale des comptes, le compte de résultat, le bilan et ses annexes parmi lesquelles la présentation du traitement comptable des opérations mentionnées au deuxième alinéa de l'article 8, ainsi qu'une évaluation des engagements hors bilan de l'Etat. Il est accompagné d'un rapport de présentation, qui indique notamment les changements des méthodes et des règles comptables appliqués au cours de l'exercice". 


\section{A TEORIA CLÁSSICA DO ORÇAMENTO}

O presente capítulo introduz as resenhas doutrinárias de três dos principais representantes do que se convencionou chamar de Teoria Clássica do Orçamento: Paul Laband, Gaston Jèze e Léon Duguit. Os postulados assentados por esses estudiosos condicionaram, e ainda condicionam, as análises jurídicas feitas acerca da Lei de Orçamento, inclusive no Brasil, além de representarem o referencial teórico basilar para que possa ser discutida a natureza jurídica da Lei de Orçamento à luz do ordenamento jurídico brasileiro.

Três são as seções em que este capítulo se divide: a primeira dedicada ao exame da doutrina de Laband; a segunda, aos contornos da linha teórica de Jèze; e a terceira, à análise dos estudos de Duguit. Os aspectos centrais de suas teorias serão retomados, ao longo deste trabalho, sempre que necessários ao debate dos temas investigados.

\subsection{A Lei do Orçamento em Paul Laband}

A construção doutrinária de Paul Laband não se forjou ao arrepio do ordenamento jurídico. Ao contrário, a elaboração de toda uma teoria sobre a Lei de Orçamento decorreu de meticuloso exame dos dispositivos constitucionais vigentes na Prússia do século XIX. Laband pretendeu elaborar uma concepção jurídica isenta, norteando-se por um exame positivista $^{240}$. De qualquer forma, o contexto político e institucional vigentes remontam um período de conflitos constitucionais entre o Governo e o Parlamento, envolvendo a não aprovação da lei orçamentária ${ }^{241}$.

A Constituição da Prússia estabeleceu que, anualmente, os ingressos e gastos do Estado deveriam ser fixados no Orçamento Geral do Estado, o qual seria estabelecido mediante uma lei.

Contudo, na concepção labandiana, a lei seria toda manifestação de vontade estatal por meio da qual se fixasse, querida e conscientemente, uma norma, independentemente da forma que lhe servisse de veículo ${ }^{242}$. Nas palavras de Laband: "la ley puede equivaler,

\footnotetext{
${ }^{240}$ LABAND, Paul. Derecho Presupuestario. Trad. Jose Zamit. Madrid: Instituto de Estudios Fiscales, 1979, p. 3.

${ }^{241}$ Ibid., p. 03.

${ }^{242}$ Ibid., p. 08.
} 
desde un punto de vista material, a una medida administrativa" ${ }^{243}$. Além disso, não seriam elementos integrantes necessários desse conceito a permanência e, tampouco, a generalidade $^{244}$. Em síntese:

Por consiguiente, el criterio esencial de la ley estriba en el contenido, siendo por ende un criterio material. La forma en que el Estado declare una regla jurídica no implica ninguna diferencia, con tal que dicha forma sea intrínsecamente válida ${ }^{245}$.

A adoção do regime constitucional teria acrescentado um requisito externo e formal ao conceito de lei: a aprovação pelos órgãos de representação popular. Portanto, ao lado da lei em sentido material, surge a lei em sentido estrito, ou formal, caracterizada por sua edição em conformidade com a exigência constitucional da aprovação parlamentar ${ }^{246}$. Segundo Laband:

Resulta, pues, que el término 'ley' también puede aplicarse, en aras de la brevedad, cuando únicamente quiere expresarse la constatación o el requisito de un acuerdo de voluntades entre el Monarca y las dos Cámaras del Parlamento o entre el Senado y la Cámara baja. La característica conceptual de la ley en este caso es una característica puramente formal; de ahí que no pueda hablarse en modo alguno de que todos los principios jurídicos que rigen con respecto a las leyes, en el sentido material de este término, tengan que aplicarse o puedan aplicarse a las actuaciones del poder estatal que no son leyes en el sentido material, pero que reciben el nombre de tales sólo porque han guardado las formas del proceso legislativo ${ }^{247}$.

Para ele, aplicando-se a concepção dualista da lei ao exame do texto constitucional que determina que o Orçamento do Estado seja fixado por intermédio de uma lei, não se obtém, em absoluto, a conclusão de que a lei que estabelece o Orçamento seja, verdadeiramente, uma lei material:

Si aplicamos este resultado al art. 99 de la Ley Constitucional prusiana, que dice: 'El Presupuesto del Estado se fijará anualmente por medio de una ley' (...) no se deduce, en modo alguno, que la fijación anual del Presupuesto por el Gobierno y la representación del pueblo sea un acto legislativo en el sentido material de la expresión ${ }^{248}$.

Fundamentada a distinção entre lei formal e lei material, Laband dirá que o conteúdo da lei orçamentária permite afirmar que não se trata de uma norma para regular situações jurídicas:

\footnotetext{
${ }^{243}$ LABAND, Paul, op. cit., p. 08/09.

${ }^{244}$ Ibid., p. 08.

${ }^{245}$ Ibid., p. 09.

246 Ibid., p. 10.

${ }^{247}$ Ibid., p. 12.

${ }^{248}$ Ibid., p. 17.
} 
es de meridiana claridad que el Presupuesto no contiene, por lo regular, principios jurídicos y que, por tanto, no es una ley en el sentido material de la palabra. El Presupuesto es una cuenta y, por cierto, una cuenta que no se refiere a gastos e ingresos ya realizados, sino a los gastos e ingresos que se esperan en el futuro, constituyendo por tanto lo que se llama una estimación previa. (...) una cuenta registra, por medio de breves indicaciones cuantitativas, los gastos e ingresos ya producidos o los que son de prever. Por lo general, el Presupuesto no fundamenta la obligación jurídica para obtener ingresos o realizar gastos, sino que, más bien, la presupone y se limita a recoger sus resultados financieros ${ }^{249}$.

Por outro lado, as atividades relacionadas à elaboração da lei orçamentária se enquadrariam, com maior acerto, como uma espécie de participação nas atividades ordinárias do Poder Executivo, muito mais do que como atividade propriamente legislativa:

ni la confección del Presupuesto para un período futuro, ni el control de las cuentas relativas a un período pasado, tienen nada que ver con la legislación, figurando más bien en el ámbito de atribuciones de la Administración; el derecho que compete constitucionalmente a la representación popular en estos dos aspectos - en cuanto que es ella la que ha de aprobar el Presupuesto y a quien se han de presentar, para su comprobación, las cuentas del Estado - no se tipifica como una participación en el llamado poder legislativo, sino como una participación en el llamado poder ejecutivo ${ }^{250}$.

Contudo, Laband reconhece não haver qualquer impedimento a que existam disposições legais de caráter material na lei orçamentária ${ }^{251}$. Portanto, não é feita qualquer afirmação apriorística acerca de um caráter meramente formal dessa lei, in abstracto, independentemente do exame do ordenamento jurídico e do tratamento conferido à Lei de Orçamento.

Destarte, a lei orçamentária poderá, ou não, ser uma lei material, a depender de que seja, ou não, o fundamento jurídico da cobrança de impostos ou da realização de despesas. Nas palavras de Laband:

Puede ser inoportuno cargarle a la ley que establece el Presupuesto un contenido que puede formularse igualmente en una ley especial; pero si el Gobierno y las dos Cámaras están de acuerdo en vincular al acto de fijación del Presupuesto tales disposiciones legales y si la Corona sanciona una ley así formulada y la promulga de acuerdo con los trámites constitucionales, la validez jurídico-pública de dicha ley no puede ser impugnada, ni en su totalidad, ni en alguna de sus partes, por el hecho de que la ley sólo está tipificada como tal ley para establecer y fijar el Presupuesto de un determinado año. (...) Puede afirmarse, en consecuencia, que todo depende del contenido ${ }^{252}$.

\footnotetext{
${ }^{249}$ LABAND, Paul, op. cit., p. 23.

${ }^{250}$ Ibid., p. 23.

${ }^{251}$ Ibid., p. 27.

${ }^{252}$ Ibid., p. 29.
} 
O princípio geral formulado por ele é o de que o orçamento é um ato administrativo que permanece vinculado à legislação vigente: "el establecimiento del Presupuesto general del Estado es un acto administrativo que ha de llevarse a cabo de conformidad con el Derecho vigente ${ }^{, 253}$.

Em decorrência desse postulado, há diversas consequências jurídicas relativas aos limites a que fica subordinada a possibilidade de modificação, pelo Parlamento, das dotações orçamentárias constantes do projeto de lei orçamentária, a aprovação e a não aprovação da lei orçamentária antes do início do exercício financeiro, além das questões referentes às alterações orçamentárias.

Uma vez que o Orçamento deve ser elaborado considerando-se obrigações jurídicas e legais às quais o Estado já se encontra previamente vinculado, há limites tanto para o Governo quanto para o Parlamento relativamente à possibilidade de inscrição de determinadas dotações orçamentárias. Em outras palavras, as "obligaciones jurídicociviles del Tesoro Público (...) imponen unas limitaciones a la supresión de partidas en los proyectos presupuestarios, 254 .

Ademais, a existência de leis que determinassem o ingresso de certas receitas, bem como de outras que estipulassem a obrigatoriedade de execução de despesas cerceariam a discricionariedade do Governo e do Parlamento na apresentação do projeto de lei orçamentária, bem como em sua aprovação ${ }^{255}$.

Dessa forma, a questão sobre os limites de modificação do projeto de Orçamento pelo Parlamento termina por levar à necessidade de separação do Orçamento em dois diferentes blocos ou conjuntos de despesas: i) aquele conformado pela legislação vigente; e ii) aquele que não se encontra submetido à qualquer constrangimento jurídico ou legislativo prévio. Nas palavras de Paul Laband:

De ahí que la respuesta a la pregunta de hasta qué punto la representación política está facultada para modificar el Presupuesto presentado por el Gobierno - es decir: suprimir, reducir o aumentar alguna o algunas de las partidas del mismo - requiera una división del Presupuesto en dos sectores conceptuales: el del que está circunscrito y colmado por el Derecho vigente y el del que está fuera del mismo ${ }^{256}$.

\footnotetext{
${ }^{253}$ LABAND, Paul, op. cit., p. 61.

${ }^{254}$ Ibid., p. 35.

255 Ibid., p. 36.

${ }^{256}$ Ibid., p. 36.
} 
Nesse sentido, a supressão de uma determinada rubrica relativa a um imposto legalmente vigente, pelo Parlamento, será considerado um ato nulo, destituído de eficácia jurídica:

la supresión en el Presupuesto, por parte del Parlamento y sin el consentimiento del Gobierno, de un impuesto legalmente vigente, sería una violación de la ley, un acto nulo desde el punto de vista del Derecho público ${ }^{257}$.

De modo idêntico, o Parlamento não se encontraria autorizado pelo ordenamento prussiano a suprimir dotações relativas a contratos jurídicos firmados: "En consecuencia, la Cámara baja no podrá suprimir los gastos derivados de contratos jurídico-civiles válidos, toda vez que sus decisiones no pueden liberar al Estado de obligaciones ya contraídas" 258 .

Além disso, a par dessas obrigações decorrentes de contratos firmados pelo Estado, existiriam numerosas despesas decorrentes de leis instituídas pelo Estado, e que, em razão disso, ostentariam fundamento jurídico-público. Essa segunda espécie de despesas também implicaria em restrições à atuação do Parlamento, visto que os gastos decorrentes de leis outrora adotadas não poderiam ser deliberadamente excluídos do projeto de lei orçamentária:

no puede depender del libre albedrío del Parlamento suprimir contra la voluntad del Gobierno, procediendo a su eliminación en el Presupuesto, las prisiones, las Universidades, el ejército y los cargos públicos, puesto que todo ello son instituciones estatales fundadas en la ley; y esta es la razón también de que la Administración, aunque no esté obligada a ello por el Derecho Civil, esté facultada por el Derecho Público para realizar los gastos que resulten necesarios en orden a conservar y mantener dichas instituciones ${ }^{259}$.

Portanto, não se encontraria entre as faculdades do Parlamento negar-se a autorizar gastos necessários para a continuidade do funcionamento de instituições estatais legalmente existentes ${ }^{260}$.

Em síntese, a tese geral formulada por Laband será a de que o Parlamento somente poderá suprimir, do projeto de lei orçamentária, dotações que não fossem necessárias para a execução das leis e para a manutenção das instituições estatais existentes. Em outras

${ }^{257}$ LABAND, Paul, op. cit., p. 39.

${ }^{258}$ Ibid., p. 58.

${ }^{259}$ Ibid., p. 59.

${ }^{260}$ Ibid., p. 61. 
palavras, o Parlamento somente pode efetuar modificações no projeto de lei orçamentária relativamente aos gastos classificados como discricionários ${ }^{261}$.

Com relação às despesas discricionárias, o Parlamento gozaria de total discricionariedade na modificação das dotações orçamentárias constantes do projeto de lei orçamentária: "El Parlamento es libre de suprimir a su voluntad, en todo o en parte, estos gastos y el Gobierno no puede realizarlos sin la autorización del Parlamento",262.

Haveria, contudo, uma ampla faixa de despesas situadas entre as discricionárias e as obrigatórias, para as quais não estariam detalhados e regulamentados os modos e circunstâncias requeridos para aplicação dos fundos e, nem tampouco, dos montantes necessários. Tal faixa se refereria, justamente, aos recursos necessários para a manutenção das entidades e órgãos do Estado, a exemplo do número de cargos e da remuneração dos funcionários, visto que "existe, evidentemente, la posibilidad de llevar a cabo la organización de los puestos y cargos públicos de manera muy variada y con muy distintos costes sin transgredir las líneas fundamentales de dicha organización, trazadas por la 'ley",263.

A questão tormentosa, nesse contexto, é a identificação de quais são os gastos ou instituições que resultam necessários para uma eficaz e adequada execução das leis vigentes no ordenamento jurídico ${ }^{264}$, uma vez que, ao Parlamento, não restaria facultado, por meio de limitações orçamentárias, constranger a Administração a executar imperfeita e insuficientemente as leis outrora aprovadas.

Com relação a tais espécies de gastos - faixa situada entre as despesas discricionárias e as obrigatórias -, deveria haver um prévio acordo entre Governo e Parlamento, que não poderia ser rescindido unilateralmente por nenhuma das partes envolvidas:

la naturaleza contractual se manifiesta en el hecho de que el acuerdo, una vez declarado y con validez jurídica, no puede ser rescindido unilateralmente por una de las partes. El acuerdo ya convenido entre el Gobierno y el Parlamento, al igual que el contrato en el ámbito del Derecho Civil, no puede ser anulado o modificado por disensión, sino sólo por contrarius consensus, es decir: por otro acuerdo distinto de voluntad ${ }^{265}$.

\footnotetext{
${ }^{261}$ LABAND, Paul, op. cit., p. 65.

262 Ibid., p. 65.

${ }^{263}$ Ibid., p. 66.

${ }^{264}$ Ibid., p. 67.

${ }^{265}$ Ibid., p. 71.
} 
Adicionalmente, Laband adota o princípio da força vinculante das resoluções assumidas pelo Parlamento, nos termos seguintes: "Lo que un Parlamento haya decidido válidamente extiende sus efectos a los períodos subsiguientes, independientemente de que el Parlamento que le siga apruebe o desapruebe la resolución"266.

Para Laband, seria um contrasenso que o ordenamento jurídico instituísse órgãos estatais permanentes e, ao mesmo tempo, fizesse depender a existência de tais órgãos à aprovação dos recursos necessários à sua manutenção, anualmente, por meio da lei orçamentária $^{267}$. Por isso, os recursos consignados no orçamento para o custeio de instituições permanentes não teriam significação por si mesmos - existem apenas em função da preservação das instituições a que são consignados.

\begin{abstract}
En efecto: de la misma manera que el Gobierno no puede crear unilateralmente nuevos establecimientos ni ampliar los existentes, el Parlamento tampoco puede suprimirlos unilateralmente ni restringir su envergadura tradicional o legal. Y está claro que si el Parlamento estuviera en condiciones, en virtud de los acuerdos tomados durante la discusión del Presupuesto, de negar los gastos indispensables para la continuación de estos establecimientos, tendría en sus manos cada año el poder de suprimirlos o de atrofiarlos e invalidarlos ${ }^{268}$.
\end{abstract}

Com relação aos limites a que se encontram submetidos tanto o Governo quanto o Parlamento, nas discussões e aprovação da Lei de Orçamento, essas seriam as principais conclusões defendidas pela doutrina labandiana ${ }^{269}$ :

i) o Governo não pode incrementar, unilateralmente, o número de órgãos e cargos públicos existentes, tampouco a remuneração dos funcionários;

ii) o Parlamento não pode negar, de forma unilateral, os recursos necessários para os organismos existentes;

iii) o Parlamento não pode consignar dotações insuficientes às instituições existentes, visto que, por via inversa, estaria extinguindo tais órgãos/cargos;

iv) o Parlamento não pode negar autorização para os gastos de custeio necessários à preservação dos organismos públicos existentes, da mesma forma como a regra aplicável aos gastos de pessoal.

Em síntese, a existência dos organismos permanentes do Estado, legalmente constituídos, não se encontra de qualquer forma condicionada pela aprovação anual do

\footnotetext{
${ }^{266}$ LABAND, Paul, op. cit., p. 70.

${ }^{267}$ Ibid., p. 71/72.

${ }^{268}$ Ibid., p. 85.

${ }^{269}$ Ibid., p. 74/76.
} 
Orçamento $^{270}$. Destarte, ao Parlamento não se encontra atribuída a faculdade de negar autorização para a realização da maior parte dos gastos de funcionamento da máquina estatal.

Formuladas tais premissas, a argumentação labandiana se concentrará na análise dos efeitos jurídico-públicos decorrentes da aprovação da lei orçamentária.

Segundo Laband, para que o Orçamento tivesse autêntica força de lei, seria necessária a presença simultânea de uma ordem para obtenção das receitas previstas e para realização das despesas fixadas e, de outro lado, uma proibição de arrecadação de quaisquer receitas que não estivessem previstas e de realização de gastos que não estivessem fixadas. Em suas palavras:

para que el Presupuesto tuviera auténtica fuerza de ley sería preciso que en él figuraran
una orden positiva y, al mismo tiempo, una prohibición, dirigidas ambas al Gobierno y
concebidas en los siguientes términos:
la orden de hacer efectivos los ingresos incluidos en el Presupuesto en la cuantía por
éste indicada y de llevar a cabo los gastos enumerados en el Presupuesto, también en la
cuantía por él indicada.
y la prohibición de hacer efectivo un ingreso y llevar a cabo un gasto que no se hallen
establecidos en el Presupuesto $^{271}$.

Mais do que isso, considerar a lei orçamentária uma autêntica lei tornaria necessário reconhecer como infrações orçamentárias todos os desvios ocorridos em relação à lei previamente aprovada: gastos adicionais, economias de despesas, reduções de ingressos e excessos de arrecadação. Conforme Laband:

Si se quiere conferir a la ley presupuestaria auténtica fuerza de ley, en el sentido corriente de esta expresión, habría que declarar infracciones legales todas las desviaciones con respecto al Presupuesto, o sea: no solamente los gastos adicionales, sino también los ahorros de gastos, las reducciones de ingresos y los excesos de ingresos $^{272}$.

Essa afirmação, contudo, não impede que ele reconheça que, por força da natureza da matéria, não há como exigir que os ingressos e despesas efetivamente realizados sejam idênticos àqueles constantes da Lei Orçamentária aprovada:

se considera natural y por encima de toda discusión que el saldo de los ingresos y gastos que, efectivamente, han tenido lugar diferirá de las estimaciones establecidas por la ley presupuestaria y que, dada la naturaleza de la materia, tiene que diferir forzosamente. La

${ }^{270}$ LABAND, Paul, op. cit., p. 74.

${ }^{271}$ Ibid., p. 89/90.

${ }^{272}$ Ibid., p. 90. 
misma Ley Constitucional prevé el caso de excesos con respecto a lo presupuestado y ordena lo que procede hacer en tales casos ${ }^{273}$.

Para Laband, não haveria, ness lei, uma ordem, um mandamento ou uma proibição. Mesmo a idéia de que existiria uma autorização para que o Governo efetuasse as despesas é falsa na medida em que a maior parte das despesas não dependeria da referida autorização ${ }^{274}$.

Portanto, a inclusão de uma dotação na lei orçamentária não implicaria em nenhuma obrigação para que o Governo efetivamente tivesse que realizar tal gasto. A efetivação de uma despesa poderia ser impossível em alguns casos, em certas hipóteses as funções a serem realizadas pela Administração poderiam ser alcançadas com custos menores do que aqueles previstos. Em todos esses casos, "sería pura insensatez considerar que el Gobierno está obligado a la prestación de tales gastos por estar previstos en la ley presupuestaria" 275 .

Além disso, poderia haver outras razões de ordem política, econômica e fiscal para que despesas não fossem realizadas:

el Gobierno también puede tener razones de otra especie para omitir unos gastos autorizados en el Presupuesto, especialmente cuando amenazadoras circunstancias políticas exigen la momentánea acumulación de capital o cuando los ingresos son inferiores a los estimados en el Presupuesto, de forma que sea de temer un déficit. No obstante, cuando hace dos años sobrevino un caso de éstos, prácticamente toda la prensa defendió la idea de que el Gobierno no debía prescindir de aquellos gastos cuyos recursos estuvieran consignados en el Presupuesto, ya que, en caso contrario, infringiría la ley presupuestaria. Esta idea se debe a una equivocada interpretación de la importancia del Presupuesto y es una consecuencia del error consistente en creer que la ley presupuestaria es una ley en el sentido material de la palabra ${ }^{276}$.

Acrescente-se, ainda, hipóteses em que resultam necessárias despesas que não foram previamente fixadas no Orçamento, a exemplo de acontecimentos inesperados, erros de previsão e planejamento e mesmo enganos de programação ${ }^{277}$. Como salienta Laband, "en todos estos casos, constituye un craso error considerar los gastos adicionales como ilegales o como infracciones de la ley presupuestaria y afirmar que el Gobierno no está facultado para su realización",278.

\footnotetext{
${ }^{273}$ LABAND, Paul, op. cit., p. 90.

${ }^{274}$ Ibid., p. 91.

${ }^{275}$ Ibid., p. 93.

${ }^{276}$ Ibid., p. 93.

${ }^{277}$ Ibid., p. 94.

${ }^{278}$ Ibid., p. 94.
} 
Por ser equivocada a concepção de que o Governo comete uma ilegalidade para cada um dos gastos que não foram originalmente contemplados no Orçamento, a aprovação posterior do Parlamento aos referidos gastos, na forma fixada pelo art. 104 da Constituição Prussiana, permitiria concebê-la como uma retificação ou complemento do Orçamento originalmente aprovado ${ }^{279}$. Efetivamente, dispõe o $\$ 1^{\circ}$ do art. 104 que "en los casos de extralimitaciones presupuestarias será necesaria la aprobación posterior de las Cámaras".

Logicamente, o posicionamento doutrinário do Parlamento na Prússia diferia do entendimento defendido por Laband. O Poder Legislativo advogava a vinculação do Governo a todas as dotações orçamentárias, tais como constantes da Lei de Orçamento, sem que houvesse a possibilidade de exceder despesas ou de não realizar gastos:

Con arreglo a una idea, reiterada y consecuentemente postulada por la Cámara de Diputados prusiana, es vinculante para el Gobierno toda partida presupuestaria concreta tal como se haya incluido en el proyecto de Presupuesto presentado a la Cámara y haya sido aprobada por ésta, o sea, son vinculantes todos los detalles y pormenores del llamado Presupuesto administrativo; el Gobierno no puede sobrepasar en ninguno de los gastos la suma presupuestada, ni siquiera en el caso de que en otros gastos se hayan hecho unos ahorros equivalentes en su cuantía, a menos que la misma ley presupuestaria haya autorizado una transferencia de esta naturaleza ${ }^{280}$.

A teoria labandiana, portanto, discute a todo momento qual o espaço discricionário deixado tanto ao Parlamento, na discussão, alteração e votação da Lei de Orçamento, quanto ao Governo, no encaminhamento da proposta e em sua execução.

As formulações doutrinárias a respeito da natureza das dotações orçamentárias, de sua classificação e dos limites deixados ao Governo e ao Parlamento em sua alteração levantam relevantes reflexões, a par de se constituírem em discussões atuais da mais alta pertinência.

A progressiva especialização das discriminações das dotações orçamentárias, pelo Parlamento, assim como a exigência gradativa de mais amplas justificativas acerca das aplicações dos recursos, em contraposição à prática antiga de autorização global, não passa despercebida nos exames de Laband ${ }^{281}$. Contudo, para o doutrinador, dentro dos limites oferecidos pelo Parlamento, o Governo gozaria de plena liberdade de disposição e movimento $^{282}$.

\footnotetext{
${ }^{279}$ LABAND, Paul, op. cit., p. 95.

${ }^{280}$ Ibid., p. 97.

281 Ibid., p. 102.

282 Ibid., p. 102.
} 
Por conseguinte, no seio da elaboração doutrinária de Laband, existe o embrião de um moderno e relevante princípio jurídico, o princípio da flexibilidade:

Cuando, por ejemplo, el anexo al proyecto de ley presupuestaria consigna 6.000 táleros para la biblioteca pública de X y el Parlamento deja intacta esta partida, es indudable que el ministro infringe el Presupuesto si aplica a dicha biblioteca 8.000 táleros, por más que ahorre en otras bibliotecas públicas la diferencia de 2.000 táleros, es decir, a pesar de que no se altera la suma total consignada para bibliotecas públicas; y esto es así porque el Parlamento no ha reconocido en la cuantía de 8.000 táleros las necesidades de la biblioteca de X. Pero sigue reservada al ministro la decisión sobre la cantidad, dentro de la suma aprobada, que ha de aplicarse a los salarios de encuadernadores y la que se ha de emplear en nuevas adquisiciones, o sobre cómo ha de distribuirse esta última entre las distintas parcelas bibliográficas ${ }^{283}$.

O autor, portanto, tenta encontrar uma possível composição que contemple Governo e Parlamento, tendo em vista os conflitos constitucionais que os envolveram na metade do século XIX na Prússia. Por um lado, deve haver uma certa especialização das dotações orçamentárias; de outro, ao Governo deve ser conferida uma certa liberdade de movimentação que lhe permita tratar melhor do gerenciamento da máquina pública.

Ainda assim, não deixa de reconhecer que a premissa desenvolvida poderá levar a uma série de conflitos, visto que, na maioria das vezes, somente o exame concreto da dotação permitirá revelar os limites a que se encontram sujeitos Governo e Parlamento. Em suas palavras:

Por supuesto, es imposible negar que el principio por nosotros establecido puede llevar en su realización práctica a múltiples conflictos, ya que, en una enorme cantidad de partidas presupuestarias, podrá ponerse en duda el grado de especialización a que el Parlamento haya extendido su comprobación y, por tanto, también su aprobación. (...) Constituye, sin embargo, un error fatal creer que se puede orillar esta dificultad sustituyendo la comprobación pormenorizada y efectiva de cada caso concreto por reglas generales y abstractas ${ }^{284}$.

E, mais adiante, arremata:

La única solución práctica, en orden a evitar los conflictos y litigios entre Gobierno y Parlamento acerca del concepto de infracciones presupuestarias, es el establecimiento de un Presupuesto normal detallado. En él no han de figurar, como en los Presupuestos publicados hasta ahora por la Recopilación de Leyes, las necesidades de extensas ramas de la Administración en una única suma, sino que las partidas han de especificarse en todos aquellos detalles que no afecten a la libre disposición del jefe administrativo dentro de la finalidad indicada de la suma ${ }^{285}$.

${ }^{283}$ LABAND, Paul, op. cit., p. 102/103.

284 Ibid., p. 103.

285 Ibid., p. 104. 
Dois últimos questionamentos são levantados por Laband: i) a possibilidade de que o Parlamento efetivamente controle o grau de cumprimento, pelo Governo, das previsões orçamentárias estabelecidas; e ii) o instrumento jurídico adequado para a responsabilização por infrações orçamentárias ${ }^{286}$.

Isso porque, como já se salientou, em conformidade ao ordenamento jurídico prussiano, "el Gobierno está obligado a pedir la aprobación del Parlamento para todas las infracciones presupuestarias y para todos los gastos extrapresupuestarios"287.

A resposta de Laband ao primeiro questionamento será a de que, tanto Governo quanto Parlamento, necessitam de uma instituição para exercer tal controle: "De ahí que, ya antes de que se implantara el régimen constitucional, existiera a estos efectos la Cámara Suprema de Cuentas",288.

Para essa questão, a Lei Constitucional Prussiana deixava assentado, em seu art. 104, que:

La Cuenta general sobre los resultados del Presupuesto de cada año, incluida una visión general de las Deudas del Estado, se presentará a las cámaras con las observaciones de la Cámara Suprema de Cuentas para descargo del Gobierno del Estado.

As Contas Gerais do Estado seriam, no dizer de Laband, uma mera compilação dos resultados obtidos em cada uma das contas de caixa; logoportanto, a comprovação de sua exatidão seria, tão-somente, um trabalho de cálculo matemático ${ }^{289}$.

As observações feitas pela Câmara Suprema de Contas, a serem apresentadas ao Parlamento, poderiam ser divididas em três modalidades: i) exatidão numérica de cada uma das contas do Caixa; ii) licitude orçamentária das despesas; e iii) erros da Administração ${ }^{290}$.

O Parlamento teria passado a exigir, cada vez mais, para o julgamento favorável das contas do Governo, não somente a exatidão numérica das contas, como também as anotações e reparos feitos acerca das movimentações financeiras havidas. Em outros termos, exige-se, progressivamente, uma visão geral sobre a situação financeira e contábil, bem como das deficiências apresentadas pela Administração ${ }^{291}$.

\footnotetext{
${ }^{286}$ LABAND, Paul, op. cit., p. 108.

${ }^{287}$ Ibid., p. 105.

${ }^{288}$ Ibid., p. 108.

${ }^{289}$ Ibid., p. 110.

290 Ibid., p. 109.

${ }^{291}$ Ibid., p. 110.
} 
Todavia, para Laband, careceria de qualquer fundamento a exigência, pelo Parlamento, do panorama geral acerca da gestão orçamentária e financeira da Administração para a outorga da aprovação das contas do Governo. Nesse sentido, constam as críticas opostas pela argumentação labandiana nos seguintes excertos:

conocer también las observaciones de esta última especie pueda justificarse por ciertas razones de naturaleza política; pero hacer depender de ello el otorgamiento del descargo carece a todas luces de justificación jurídico-pública, dado que la constatación de tales defectos puede inducir, desde luego, a tomar medidas que los remedien en el futuro, pero no puede justificar retroactivamente, ni prolongar hasta ahora, la responsabilidad de los ministros por gastos hechos legal y ordenadamente ${ }^{292}$.

En cambio, el Parlamento tiene pleno derecho a que la mencionada Cámara le informe de las desviaciones que se aprecien en las cuentas particulares de cada rama administrativa con respecto al Presupuesto acordado. Este derecho del Parlamento no se cumplió en lo esencial hasta el año 1862: a partir de este año se presentan al Parlamento no sólo las certificaciones de la Cámara Suprema de Cuentas sobre la exactitud aritmética de las cuentas, sino también una recopilación de los ingresos y gastos efectivamente habidos, comparados con las estimaciones de la ley presupuestaria, así como los reparos materiales de la Cámara Suprema de Cuentas ${ }^{293}$.

Dessa forma, uma vez que a verificação das infrações orçamentárias se insere nas competências atribuídas à Câmara Suprema de Contas, o Parlamento carece de qualquer base sólida para controlar, por si mesmo, o efetivo cumprimento do Orçamento aprovado $^{294}$. Em consequência, à primeira questão, Laband responderá retirando tal competência das atribuições do Parlamento, além de negar fundamentação jurídica à aprovação das contas, pelo Parlamento.

Por outro lado, relativamente aos meios jurídicos disponíveis para a responsabilização das violações ao Orçamento, o exame do ordenamento jurídico prussiano revelar-se-ia precário, deixando de instrumentalizar o Parlamento com as necessárias ferramentas. Em adição,, no entendimento labandiano, a responsabilidade jurídica dos Ministros, prevista na Constituição, não faria qualquer menção a eventuais infrações à Lei de Orçamento:

La responsabilidad jurídico-pública de los ministros frente al Parlamento está regulada en el artículo 61 de la Ley Constitucional. En él se restringe el derecho de acusación de las Cámaras a los tres casos 'delictivos de violación de la Constitución, soborno y traición'. No se cita la infracción del Presupuesto ni la verificación de gastos extrapresupuestarios. En las sesiones parlamentarias, desde luego, se ha solido subsumir estas acciones en el concepto de 'violación de la Constitución'; pero, aunque haya de

${ }^{292}$ LABAND, Paul, op. cit., p. 111.

293 Ibid., p. 111.

${ }^{294}$ Ibid., p. 112/113. 
admitirse que puede haber casos en los que la realización de gastos se calificaría como violación del art. 99 de la Ley Constitucional, es innegable que declarar con carácter general como violación de la Constitución la realización de todo gasto que no esté previsto en el Presupuesto, o su realización en una cuantia superior a la prevista, se opone intrínsecamente tanto al auténtico concepto de ley presupuestaria como a las reglas de la interpretación lógica ${ }^{295}$.

Portanto, no ordenamento jurídico em vigor, não existiria uma lei que responsabilizasse os Ministros de Estado por infrações à Lei Orçamentária. Em decorrência disso, o Parlamento poderia, única e exclusivamente, negar sua autorização para as infrações orçamentárias e para os gastos extraorçamentários, além de não aprovar as contas do Governo. Contudo, e esse aspecto é fundamental, tais decisões parlamentares não acarretariam consequências práticas de qualquer espécie:

Por consiguiente, el Parlamento ha de limitarse única y exclusivamente a negar la autorización de las infracciones presupuestarias y de los gastos extrapresupuestarios y a rechazar el descargo del Gobierno. Es posible que la no concesión del descargo le resulte inoportuna al Gobierno; pero está fuera de toda duda que ello no acarrea consecuencias prácticas de ninguna especie y que, en último término, tal vez el ministerio se acostumbre a prescindir del descargo otorgado por el Parlamento o del otorgado por una de las dos Cámaras que lo componen ${ }^{296}$.

O derradeiro tema investigado por Laband diz respeito à não aprovação da Lei de Orçamento e seus efeitos jurídicos. Para o autor, existiria uma lacuna na Lei Constitucional Prussiana, visto que ela não conteria nenhum dispositivo que disciplinasse a não aprovação da lei orçamentária. O que se exigiria seria, tão-somente, um acordo entre a Coroa e as Câmaras do Parlamento ${ }^{297}$.

De acordo com o art. 109 da Constituição da Prússia, a arrecadação dos impostos prosseguiria independentemente da promulgação de uma lei orçamentária, ou seja, os recursos continuariam afluindo para os cofres do Tesouro Público. No caso de o Governo não ser autorizado a realizar despesas em decorrência da não aprovação da lei orçamentária, os recursos teriam que permanecer imobilizados no Caixa do Governo ${ }^{298}$.

Entretanto, a realização prática dessa teoria significaria a paralisação das atividades estatais, a dissolução e desorganização do Estado ${ }^{299}$. Por isso, um princípio que levasse a tais consequências não poderia ser encampado pela Constituição do Estado, no entendimento de Laband.

\footnotetext{
${ }^{295}$ LABAND, Paul, op. cit., p. 113.

296 Ibid., p. 115.

297 Ibid., p. 119.

298 Ibid., p. 121.

${ }^{299}$ Ibid., p. 121.
} 
Além disso, a Constituição não teria determinado qualquer obrigação para que Governo e Parlamento entrassem em acordo para a aprovação da Lei Orçamentária. Por um lado, não haveria qualquer obrigação jurídica para que o Parlamento autorizasse o projeto encaminhado pelo Governo; por outro, tampouco existiria a obrigação de o Governo consentir com modificações feitas no projeto de lei pela Câmara Legislativa ${ }^{300}$.

Para solucionar tal impasse, Laband retoma as premissas anteriormente assentadas a respeito do caráter do orçamento e das dotações orçamentárias, bem como das restrições existentes nas modificações do projeto de lei de orçamento:

Todas las dificultades de esta cuestión, aparentemente intrincada y confusa, se resuelven sin embargo tomando como punto de partida el principio fundamental y correcto: la ley presupuestaria no constituye al 'fundamento legal' ni de la realización de gastos ni de la recaudación de ingresos, siendo solamente la constatación del acuerdo entre el Gobierno y el Parlamento sobre la idoneidad de la estimación previa y sobre la necesidad y conveniencia de las sumas en ella indicadas. El fundamento legal para la realización de los gastos ya existe, sin necesidad de Presupuesto, en la inmensa mayoría de los mismos. De ahí que la no aprobación de la ley presupuestaria no implique una inmovilización de los fondos del Estado. Pero el ministerio sigue siendo responsable de cada gasto concreto y está obligado a aportar ante el Parlamento la prueba de que dicho gasto, de suyo y en la cuantía consumada, ha sido requerido por las leyes o por el bien público. Por consiguiente, la posición jurídica del Gobierno con respecto a la totalidad de los gastos públicos en el caso de que no se apruebe a la ley presupuestaria, es semejante a la que tiene, con respecto a las infracciones presupuestarias y a los gastos extrapresupuestarios, en el mismo caso de no aprobación de la ley presupuestaria ${ }^{301}$.

Logo, os mesmos princípios desenvolvidos para a fixação dos limites ao direito de modificação do projeto de lei orçamentária, e que serviriam para o exame e análise das infrações orçamentárias, implicariam a obrigação jurídica de o Parlamento autorizar todos os gastos decorrentes da legislação vigente. Com essa conclusão, Laband termina por legitimar a administração financeira desenvolvida pelo Governo, sem o respaldo de uma lei orçamentária previamente aprovada:

Ya es sabido que en Prusia se ha presentado, en repetidas y frecuentes ocasiones, el caso de que el Gobierno tenga que llevar a efecto la administración financiera sin ley presupuestaria, puesto que hasta estos últimos años nunca se había conseguido aprobar la ley presupuestaria antes de iniciarse el año administrativo ${ }^{302}$.

Visto que, com relação a todas as despesas decorrentes de obrigações constitucionais ou legais, assim como das obrigações civis do Estado e das despesas necessárias ao funcionamento das instituições e órgãos existentes, o Parlamento não se

${ }^{300}$ LABAND, Paul, op. cit., p. 124.

${ }^{301}$ Ibid., p. 126.

${ }^{302}$ Ibid., p. 126/127. 
encontraria legitimado a deixar de contemplar as necessárias dotações na Lei de Orçamento, o Governo estaria facultado a realizar todas essas espécies de gastos, mesmo sem a existência de lei orçamentária previamente aprovada. Em resumo, na versão labandiana, o papel do Parlamento é severamente reduzido, fortalecendo as prerrogativas conferidas ao Governo.

Com o desenvolvimento dessa teoria, Laband produziu uma verdadeira revolução no exame da natureza da Lei Orçamentária, influenciando fortemente as discussões doutrinárias em diversos países, a exemplo de França e Itália, onde sua doutrina encontrou solo fértil para o florescimento.

\subsection{O Orçamento em Gaston Jèze}

Jèze abre o Cours de Science des Finances com a afirmação peremptória de que o Orçamento é, essencialmente, um ato político: "Le budget est essentiellement um acte politique $^{, 303}$. O desenvolvimento posterior de sua análise acerca da lei orçamentária encontra-se indissociavelmente condicionado por tal concepção.

O Orçamento representaria, portanto, um programa de ação política, um ato governamental por excelência. Todo governo no poder tem, necessariamente, um plano de ação. Os partidos políticos, dentro do Estado moderno, opõem seus programas e concepções na disputa pelo poder. Mesmo os conservadores possuem um programa: o de não modificar as instituições existentes e manterem o status quo ${ }^{304}$.

A realização de um certo programa político se traduz, necessariamente, em um conjunto de novas despesas ou mesmo de redução de gastos. O Orçamento, inserido nesse contexto, não passa de uma lista dos créditos demandados pelo Governo, de acordo com o partido político que lhe confere maioria no Parlamento, para a realização de um determinado programa de ação política ${ }^{305}$.

Em razão da necessidade de financiamento dessa ação do Estado, surge o problema das receitas e impostos e da repartição dos custos entre os indivíduos: problema

\footnotetext{
${ }^{303}$ JÈZE, Gaston. Cours de Science des Finances et de Législation Financière Française. Sixième Édition. Paris: Marcel Giard, 1922, p. I.

${ }^{304}$ Ibid., p. I/II.

${ }^{305}$ JÈZE, Gaston, op. cit., p. I/II.
} 
essencialmente político, visto que se trata de saber quem pagará, quanto pagará e de que maneira pagará ${ }^{306}$.

Sobre isso, Jèze realça o imenso valor político da votação periódica do Orçamento do Estado, pelas Câmaras Legislativas ${ }^{307}$, em contraposição a um insignificante valor jurídico: "Muy a menudo, la misión del Parlamento es de orden político, sin significación jurídica",308.

Efetivamente, para ele, o Orçamento não seria jamais uma lei: “Le budget n'est jamais une loi" ${ }^{309}$. Dessa concepção, decorrem consequências jurídicas das mais diversas, tanto para os poderes enfeixados pelo Parlamento como para a própria Administração, encarregada da execução do programa de ação política do Governo.

O exame do Orçamento, levado a efeito pelo autor, a exemplo da doutrina de Duguit, separa a análise dos efeitos e características do orçamento conforme se trate do Orçamento das Receitas e do Orçamento das Despesas.

Ao proceder à análise da natureza jurídica do orçamento das receitas, Jèze, separa a investigação em receitas de impostos e de outras receitas.

Para as receitas provenientes de outras fontes que não os impostos, a exemplo de receitas de alienação de bens do Estado, o orçamento não possuiria qualquer significação jurídica, sendo apenas uma avaliação de ordem financeira.

No que se refere às receitas de impostos, as respectivas rubricas são atos jurídicos que permitem o exercício, pelos agentes administrativos, dos poderes estabelecidos e regulamentados pelas leis orgânicas dos impostos ${ }^{310}$.

Desse modo, o exercício dos poderes inscritos nas leis instituidoras dos impostos fica subordinado a uma condição particular e periódica, ou seja, a votação anual do Orçamento perante a regra vigente da anualidade dos impostos ${ }^{311}$.

\footnotetext{
${ }^{306}$ Nas palavras de Jèze: "Problème essentiellement politique, car il s'agit de savoir qui paiera, dans quelle mesure on paiera, de quelle manière on paiera". Ibid., p. I/II.

${ }^{307}$ Ibid., p. 34.

${ }^{308}$ JÈZE, Gaston. Principios Generales del Derecho Administrativo. Tomo IV. Traducción directa de la $3^{\mathrm{a}}$ edición francesa, por Julio N. San Millán Almagro. Buenos Aires: Editorial Depalma, 1950, p. 13.

309 JÈZE, Gaston. Cours de Science des Finances et de Législation Financière Française. Sixième Édition. Paris: Marcel Giard, 1922, p. 24.

310 "Quant aux recettes d'impôts, les titres juridiques de la recette sont les actes juridiques qui vont être accomplis par les agents administratifs, en exercice des pouvoirs établis et réglementés par les lois organiques d'impôts". Cf. JÈZE, Gaston. Cours de Science des Finances et de Législation Financière Française. Sixième Édition. Paris: Marcel Giard, 1922, p. 24/25.

311 "Dans ces pays, pour toutes les recettes d'impôts auxquelles on applique cette règle, le Parlement, en votant le budget des recettes, remplit la condition mise par le droit positif à l'exercice de la compétence des agents administratifs. A partir de ce moment, les agents peuvent régulièrement, par leurs actes juridiques, faire naître des créances au profit du Trésor public". JÈZE, Gaston. Cours de Science des Finances et de Législation Financière Française. Sixième Édition. Paris: Marcel Giard, 1922, p. 24/25.
} 
Em conclusão, o orçamento das receitas, na parte relativa aos impostos e em função da existência da regra da anualidade, possui a natureza jurídica de um ato-condição (actecondition $)^{312}$. Contudo, caso não vigorasse a regra da anualidade, o orçamento das receitas não possuiria qualquer significação jurídica, sendo uma estimativa de ordem puramente financeira $^{313}$.

Nesse ponto, existe uma crucial diferença entre a doutrina duguitiana e a de Jèze, reconhecida pelos próprios juristas, visto que Duguit afirmará que o Orçamento das Receitas, nos ordenamentos em que existe a regra da anualidade tributária, possui a natureza jurídica de uma lei propriamente dita ${ }^{314}$.

Consequentemente, partindo da análise do ordenamento jurídico francês, Jèze e Duguit chegam a conclusões opostas. Duguit afirma que, diante da existência da regra da anualidade dos impostos, o orçamento das receitas possui a natureza de uma lei propriamente dita ${ }^{315}$. Jèze, ao contrário, afirmará que o orçamento das receitas é, nesse caso, um ato-condição.

Para Jèze, existe uma dupla ordem de autorizações no orçamento das receitas, relativamente aos impostos: a autorização para realização dos atos jurídicos que dão origem à criação de uma receita para o Tesouro; e a autorização de se efetivar a $\operatorname{arrecadação~}^{316}$.

\footnotetext{
${ }^{312}$ Ibid., p. 24/25.

313 “Ainsi, suivant les systèmes législatifs et suivant la nature des recettes, tantôt le budget des recettes a une signification juridique - et alors c'est un acte-condition; - tantôt il n'a aucune signification juridique. En tout cas, le budget des recettes n'est jamais une loi proprement dite". Ibid., p. 24/25.

${ }^{314}$ Nas palavras de Jèze: "Le professeur Duguit affirme que le budget des recettes, dans les législations où existe la règle de l'annalité de l'impôt, a la nature juridique d'une loi proprement dite". Ibid., p. 24/25.

315 "Le budget est tantôt une loi proprement dite, tantôt une opération administrative. - D'après le prof. Duguit, a) le budget des dépenses n'est jamais une loi. C'est un acte d'administration; mais b) le budget des recettes est tantôt une loi, tantôt une simple opération administrative. Dans les pays ou le Parlement énumère chaque année les seuls impôts et les seules taxes qui pourront éter perçus dans l'année (principe de l'annalité de l'impôt), le budget, en tant qu'il fait cette énumération des impôts et taxes, contient des régles lègislatives au sens matériel. Quant à la partie du budget des recettes ou sont évalués les revenus des domaines de l'Etat, c'est une simple opération administrative. Dans les pays où l'impôt ne doit pas être renouvelé chaque année (legislations qui n'admettent pas le principe de l'annalité de l'impôt), le budget n'est pas une loi; lex tableaux indicatifs des impôts et taxes à percevoir doivent être considérés comme une simple operation administrative". Ibid., p. 23/24.

316 " $1{ }^{\circ}$. l'autorisation d'accomplir les actes juridiques qui font naître la créance au profit du trésor: constatation et liquidation des droits, redaction des matrices et rôles nominatifs; $2^{\circ}$. l'autorisation d'en opérer le recouvrement". JÈZE, Gaston. Cours de Science des Finances et de Législation Financière Française. Sixième Édition. Paris: Marcel Giard, 1922, p. 31.
} 
Método idêntico é empregado por Gaston Jèze para o exame da natureza jurídica do Orçamento das Despesas. O Orçamento prevê e autoriza todas as despesas; porém, a referida autorização não contém, para todas as despesas, a mesma significação jurídica ${ }^{317}$.

Há duas combinações principais que podem ser utilizadas. De acordo com a primeira, o orçamento encerra a condição para que os agentes administrativos exerçam, regularmente, a competência para executar os atos jurídicos necessários à criação das despesas e respectivo pagamento. $\mathrm{Na}$ ausência da aprovação do Orçamento, essa competência não pode ser legitimamente exercida. Essa primeira combinação revela maior grau de eficácia jurídica, maximum d'énergie juridique, de que pode se revestir o Orçamento das Despesas ${ }^{318}$.

Contudo, grande parte das despesas públicas anuais refere-se ao pagamento de obrigações existentes, que não podem deixar de ser satisfeitas, sob pena de afronta ao princípio do respeito aos direitos subjetivos. Nesse caso, o Parlamento encontra-se obrigado a aprovar os créditos necessários. Não existe qualquer poder discricionário de apreciação, pelo Parlamento, quanto ao valor ou às condições de pagamento, pois não pode recusar ou reduzir os créditos orçamentários ${ }^{319}$.

Em conclusão, para uma parcela das despesas, o orçamento será um ato-condição, necessário à legítima concretização dos gastos; para outra, decorrente de obrigações válidas anteriormente contraídas pelo Estado, o orçamento não possui qualquer significação jurídica, visto que o Parlamento não pode deixar de consignar tais despesas na lei que aprova o orçamento ${ }^{320}$.

O mesmo ocorrerá caso seja adotada a combinação que distingue as despesas em: i) despesas relativas ao funcionamento dos serviços públicos instituídos por leis; e ii) outras despesas. No primeiro caso, o Parlamento não pode deixar de inscrever os créditos necessários ao regular funcionamento dos serviços e, portanto, não existe, para esta categoria de despesas, qualquer significação jurídica: C'est une opération d'ordre

317 "Le budget prévoit et autorise toutes les dépenses; mais l'autorisation qu'il contient n'a pas, pour toutes les dépenses, la même significacion juridique". JÈZE, Gaston. Cours de Science des Finances et de Législation Financière Française. Sixième Édition. Paris: Marcel Giard, 1922, p. 29.

${ }^{318}$ Ibid., p. 25/26.

319 "Une grande partie des dépenses publiques annuelles est relative à l'acquittement de dettes existantes (dette publique, pensions concédées, etc.). Le principe du respect des droits subjectifs s'oppose à ce que la réalisation de ces situations - le paiement - soit empêchée, d'une mànière quelconque, par une autorité quelconque. Dès lors, le Parlement a le devoir juridique de voter les crédits; sa compétence est absolument liée; il n'a aucun pouvoir d'appréciation discrétionnaire ni quant au quantum, ni quant aux conditions et délais du paiement". Ibid., p. 25/26.

320 "Em somme, dans cette première combinación, le budget des dépenses est, au point de vue juridique, au maximum, un acte-condition; il se peut même, pour certaines dépenses, qu'il n'ait aucune signification juridique". Ibid., p. 26. 
exclusivement financier. No segundo, o orçamento das despesas será, no máximo, um atocondição para a realização dos gastos. Nas palavras de Jèze: “au bien le budget des dépenses (pour une partie des dépenses publiques) n'a aucune signification juridique; ou bien (pour une autre partie) c'est un acte-condition ${ }^{\text {,321. }}$.

Segundo o autor, o crédito orçamentário é a autorização impessoal e não individualizada, concedida aos Ministros e funcionários administrativos, para a realização de atos jurídicos que originam obrigações financeiras para o Estado:

Se dice, en general, que el crédito presupuestario es una autorización para gastar. Esta expresión carece de precisión, porque la palabra 'gasto' no tiene un sentido muy definido. De manera precisa, el crédito presupuestario es la autorización impersonal, no individualizada, concedida por el Parlamento a los ministros, jefes de los servicios públicos, para realizar, teniendo en vista un objeto público determinado, actos jurídicos creadores de obligaciones de suma de dinero, a cargo del patrimonio administrativo nacional. Entre estos actos jurídicos figuran, evidentemente, los contratos (contratos administrativos propiamente dichos o contratos de derecho privado). Esta autorización (crédito presupuestario) es impersonal en el sentido de que el Parlamento no interviene para autorizar, uno por uno, nominativamente, los contratos celebrados por los ministros para hacer funcionar los servicios públicos de los cuales se encargan. La autorización se da impersonalmente y en forma general; no es individualizada ${ }^{322}$.

As autorizações concedidas pelo Parlamento, isto é, créditos orçamentários, se constituem de três elementos integrantes: i) objeto do gasto; ii) quantia ou soma a ser despendida; e iii) período de tempo em que a despesa pode ser efetivada. O conjunto dessas limitações, de acordo com o direito francês, receberia o nome de especialidade do crédito orçamentário $^{323}$.

O Parlamento, no uso de suas atribuições, especificaria o objeto dos créditos, sem que os créditos orçamentários, por isso, deixassem de ser uma autorização impessoal, muito embora se aproximassem, cada vez mais, de uma autorização individual ${ }^{324}$. Cada um dos objetos de autorização - gastos de pessoal, gastos de material, etc - receberia o nome de capítulo orçamentário, que possuiria a seguinte significação jurídica:

mediante el crédito especializado en el capítulo presupuestario, el Parlamento concede al ministro la autorización para realizar los actos jurídicos (en particular, los contratos) necesarios para asegurar la buena ejecución del servicio especificado en el crédito. Esta autorización sólo vale para este objeto, no pudiendo utilizarse para ningún otro.

${ }^{321}$ JÈZE, Gaston. Cours de Science des Finances et de Législation Financière Française. Sixième Édition. Paris: Marcel Giard, 1922, p. 26.

322 JĖZE, Gaston. Principios Generales del Derecho Administrativo. Tomo IV. Traducción directa de la $3^{\text {a }}$ edición francesa, por Julio N. San Millán Almagro. Buenos Aires: Editorial Depalma, 1950, p. 14.

${ }^{323}$ Ibid., p. 15.

${ }^{324}$ Ibid., p. 15. 
El ministro violará esta regla al hacer un gasto sin crédito, es decir, sin lo que haya autorizado para ello el Parlamento, o al desviar un crédito del objeto especificado (cambio de un capítulo a otro).

Tal es la significación jurídica de la regla de la especialidad presupuestaria en cuanto al objeto $^{325}$.

O segundo elemento do mencionado crédito seria, justamente, o montante de recursos autorizados, que expressariam a soma máxima de recursos passível de utilização pela Administração. Nesse contexto:

La autorización parlamentaria (crédito) determina, además, de manera precisa, la suma máxima hasta la concurrencia de la cual el ministro está autorizado para realizar - con determinado objeto - actos jurídicos (contratos) que originen deudas de sumas de dinero a cargo del patrimonio administrativo nacional ${ }^{326}$.

A realização de despesas que excedessem o crédito aprovado ocasionaria o chamado "exceso en la imputación" 327 . Tal infração abrangeria tanto despesas realizadas em valores superiores ao consignados no Orçamento, como também gastos realizados sem previsão e respaldo orçamentários.

Por último, o crédito determinaria, ainda, o período de tempo durante o qual a despesa poderia ser validamente realizada, geralmente um ano, em razão da anualidade do orçamento. A violação dessa regra receberia o nome de "intervención de ejercicio",328.

Tendo estabelecido a definição de crédito e seus elementos integrantes - objeto, montante e período de tempo -, além de apontar e nomear as respectivas violações, Jèze discutirá os efeitos jurídicos decorrentes da infração das referidas regras sobre os contratos firmados pelo Estado. Por outras palavras, buscará averiguar a influência exercida pela violação dos elementos constitutivos do crédito orçamentário sobre a validade jurídica dos contratos:

Cuál es la sanción de estas reglas? Qué influencia jurídica ejerce, sobre el contrato, sobre su existencia y sobre su validez, la violación del principio general de la previa autorización concedida en forma de apertura de un crédito?

La respuesta es evidente. El contrato concluido por un ministro sin crédito o excediendo el crédito aprobado por el Parlamento, o desviando un crédito de su objeto (cambio de destino) o utilizando un crédito para un período para el que no se ha concedido, es jurídicamente válido. La irregularidad no tiene ninguna influencia sobre

\footnotetext{
325 JÈZE, Gaston. Principios Generales del Derecho Administrativo. Tomo IV. Traducción directa de la $3^{\mathrm{a}}$ edición francesa, por Julio N. San Millán Almagro. Buenos Aires: Editorial Depalma, 1950, p. 16.

${ }^{326}$ Ibid., p. 16.

${ }^{327}$ Ibid., p. 17.

${ }^{328}$ Ibid., p. 17.
} 
la existencia ni sobre la validez jurídica del contrato. No puede tampoco invocarse en apoyo de un recurso contencioso relativo al contrato ${ }^{329}$.

Em outros termos, Jèze afirma que o desrespeito ao crédito orçamentário autorizado pelo Parlamento não se reveste de qualquer significação jurídica. O contrato firmado pela Administração sem autorização orçamentária, ou violando qualquer dos elementos integrantes do crédito orçamentário, prosseguiria com sua validade inalterada. Mais do que isso, qualquer modificação do orçamento previamente aprovado não geraria qualquer efeito jurídico, restringindo-se a uma responsabilidade política:

Si falta la autorización del Parlamento, si se excede dicha autorización, ello sólo compromete generalmente la responsabilidad política de los ministros respecto a las Cámaras. Estas irregularidades no influyen sobre la validez jurídica del contrato ${ }^{330}$.

Outro tema particularmente importante no desenvolvimento da teoria de orçamento desenvolvida por ele é questão da recusa do projeto de lei orçamentária pelo Parlamento. Nesse ponto, o jurista fundamenta suas considerações retomando o corte político com que procura identificar a natureza do Orçamento; dessa forma, o problema da recusa da Lei de Orçamento possuiria uma única causa: uma motivação política, visto que os Ministros no poder não teriam angariado a confiança dos deputados ${ }^{331}$.

Nesse contexto, por meio das discussões orçamentárias o Parlamento pretende influenciar a adoção de determinada linha de orientação pelo Governo, bem como exercer uma crítica aos atos da Administração. Uma vez que, periodicamente, o Orçamento do Estado é submetido à deliberação parlamentar, o Legislativo pode, inclusive, solicitar explicações sobre os atos e projetos da Administração ${ }^{332}$.

A manifestação mais grave da falta de confiança sobre um Governo será, justamente, a recusa da aprovação da lei orçamentária, pois a recusa aos créditos orçamentários é considerada pelas Câmaras Legislativas como uma manifestação

\footnotetext{
329 JÈZE, Gaston. Principios Generales del Derecho Administrativo. Tomo IV. Traducción directa de la $3^{\text {a }}$ edición francesa, por Julio N. San Millán Almagro. Buenos Aires: Editorial Depalma, 1950, p. 18.

${ }^{330}$ Ibid., p. 13.

331 "le problème du refus des crédits en bloc (...) Ce refus n'a qu'une signification politique: les ministres au pouvoir n'ont pas la confiance des députés de la nation. Voilà l'unique motif. C'est un motif politique". JÈZE, Gaston. Cours de Science des Finances et de Législation Financière Française. Sixième Édition. Paris: Marcel Giard, 1922, p. III.

332 "Tout service public, tout acte politique entraîne une dépense, nécessite une recette. (...) Soumettre le budget périediquement au vote des Chambres, c'est forcément reconnaître à celles-ci le pouvoir de discuter non seulement le principe même des services publics, mais encore la manière dont ils sont conduits: c'est leur donner le pouvoir de demander aux Ministres des explications détaillées sur tous leurs actes, sur toutes leurs abstentions, sur tous leurs projets". JÈZE, Gaston. Cours de Science des Finances et de Législation Financière Française. Sixième Édition. Paris: Marcel Giard, 1922, p. 35.
} 
particularmente grave da falta de confiança depositada no Governo. Nas palavras do autor, “le refus des crédits budgétaires est considéré par les Chambres comme une manifestation particulièrement grave de leur méfiance envers le Gouvernement" ${ }^{333}$.

Jèze, todavia, não deixa de salientar o perigo de a atuação parlamentar degenerar-se em verdadeira obstrução legislativa ${ }^{334}$. Nesse sentido, os debates parlamentares trariam consigo um perigo, haja vista que, sob o pretexto de criticar e de exercer um controle sobre o Governo, tal poder poderia facilmente se tornar abusivo ${ }^{335}$. De qualquer forma, termina por reconhecer o poder das Câmaras de criticar a Administração, quando da votação da lei orçamentária, submetendo ao seu crivo a política geral e os atos dos Ministros ${ }^{336}$.

$\mathrm{O}$ autor procura relacionar, diretamente, a modificação dos créditos, bem como a recusa do Orçamento a motivações políticas, tão-somente. Não existem decorrências jurídicas dessa atuação parlamentar ${ }^{337}$.

Considerando-se que grande parte das despesas públicas devem ser incluídas, obrigatoriamente, pelo Parlamento, visto que decorrentes de obrigações validamente contraídas pelo Estado, e que, ademais, o descumprimento dos créditos aprovados pelo Parlamento carece de qualquer consequência ou implicação jurídica, resta o questionamento acerca do real valor da função política de discussão do Orçamento pelo Parlamento, defendida por Jèze.

\subsection{O Orçamento em Léon Duguit}

Laband trouxe à comunidade jurídica a distinção central entre o orçamento propriamente dito e a lei que o aprova. A partir desse momento, as análises feitas a respeito da Lei de Orçamento passam a considerá-la não como um ato único, unitário. Ao contrário,

\footnotetext{
${ }^{333}$ JÈZE, Gaston. Cours de Science des Finances et de Législation Financière Française. Sixième Édition. Paris: Marcel Giard, 1922, p. 34.

334 "Ces pratiques allongent considérablement la discussion du budget et pourraient facilement dégénérer en obstruction parlementaire". Ibid., p. 37.

335 "Cette pratique, il est vrai, n'est pas sans danger. Sous le prétexte de faire des critiques et d'exercer un contrôle, ce pouvoir peut devenir facilement abusive". Ibid., p. 35.

336 "Le mal est certain; néanmoins, la critique ne parait pas fondée: le pouvoir des Chambres n'est pas contestable; le nier, c'est ne tenir aucun compte des traditions parlementaires. Il est légitime, pour les membres des Chambres, à l'occasion du budget, de passer en revue la politique générale et les actes particuliers des ministres". Ibid., p. 38.

337 "Une discussion parlementaire n'est pas un débat académique; elle doit aboutir à un résultat positif, se terminer par une invitation précise à mettre à exécution le programme politique qui a les préférences de la majorité". Ibid., p. 39.
} 
teorias diversas passam a atomizar a análise dessa Lei, fato que se realça quando do exame do desenvolvimento doutrinário da teoria do Orçamento na França.

Na doutrina francesa, Léon Duguit parte da distinção do Orçamento em duas partes principais, que adquirem contornos próprios e diferenciados: Orçamento das Receitas e Orçamento das Despesas ${ }^{338}$.

A análise da natureza jurídica do Orçamento, portanto, será feita separadamente, considerando-se os distintos efeitos que decorrem de cada parte do Orçamento (receitas e despesas). Nesse contexto, assume relevo fundamental o fato de vigorar na França o princípio da anualidade dos impostos, pelo qual os impostos do exercício financeiro subsequente somente poderiam ser exigidos caso constassem designadamente do Orçamento das Receitas ${ }^{339}$.

Em outros termos, a regra vigente quanto às receitas de impostos era que os impostos possuiriam uma vigência anual, dependente de renovação expressamente consignada no Orçamento, para que pudessem ser novamente cobrados. Tal princípio, segundo Duguit, seria aplicado indistintamente às contribuições e às taxas: "Le principe de l'annalité de l'impôt s'applique indistinctement à toutes les contributions et taxes, directes et indirectes" ${ }^{, 340}$.

Considerando que o ordenamento jurídico francês contemplava a regra da anualidade, Duguit afirmará que o Orçamento das Receitas possui o caráter de lei

\footnotetext{
${ }^{338}$ De acordo com Duguit, todo Orçamento compreende, essencialmente, duas partes: na primeira, são enumeradas os impostos e outras receitas autorizadas e esta parte pode ser especialmente conhecida pela denominação de Lei de Finanças; na segunda parte, são fixadas as despesas que o governo está autorizado a executar, ou, de outra forma, os créditos autorizados ; tal parte pode ser chamada de Orçamento propriamente dito. Em suas palavras: "Tout budget comprend essentiellement deux parties: l'une où sont énumérés les impôts et revenues autorisés; c'est cette partie du budget qui porte plus spécialement le nom de loi de finances. Dans l'autre partie sont fixées les dépenses que le gouvernement est autorisé à faire, ou, sous une autre forme, les crédits qui lui sont ouverts. C'est le budget proprement dit" (grifos nossos). Cf. DUGUIT, Léon. Traité de Droit Constitutionnel. Deuxième Édition. Tome IV. Paris: Ancienne Librairie Fontemoing \& Cie. Éditeurs, 1924, p. 433.

${ }^{339}$ Como destaca Duguit, a regra da anualidade dos impostos encontra-se expressamente consagrada na Constituição Francesa: "la règle de l'annalité de l'impôt a été consacrée expressément par l'article 1 du titre V de la constitution de 1791: 'Les contributions publiques seront délibérées et fixées chaque année par le corps législatif et ne pourront subsister au delà du dernier jour de la session suivante si elles n'ont pas été expresment renouvelées'. Elle a été consacrée aussi par l'article 17 de la constitution de 1848 qui reproduit, il est vrai, le texte des Chartes". DUGUIT, Léon, op. cit., p. 437. Duguit também destaca as consequências da regra da anualidade: "Des tableaux fixent l'évaluation détaillée du montant des recettes prévues pour chaque source de recette. La loi autorise pour l'exercice, conformément aux lois existantes, la perception des divers droits, produits et revenues énoncés dans les tableaux annexés. Toute contribution, toute taxe qui ne serait point énumérée dans les tableaux ne pourrait pint ètre perçue pendant l'année. C'est application du principe de l'annalité de l'impôt précédemment étudié". Ibid., p. 435.

${ }^{340}$ DUGUIT, Léon, op. cit., p. 436.
} 
material, por condicionar a existência e cobrança dos impostos e taxas para cada exercício financeiro $^{341}$.

E ponderando o entendimento de Jéze, Duguit destaca que a opinião de Jèze de que a decisão constante da Lei de Orçamento não seria mais do que a condição da aplicação das leis de impostos e a condição necessária para o exercício da competência dos funcionários relativamente às receitas não seria exata. Para Duguit, findo o exercício financeiro, a lei dos impostos não existiria mais, como se tivesse sido revogada; consequentemente, a decisão orçamentária que a faria renascer, criaria um novo imposto e, por isso, seria um ato legislativo material ${ }^{342}$.

Por ser uma lei material, o Orçamento das Receitas poderia conter dispositivos modificando a organização administrativa do Estado ou outras disposições legais, mesmo civis ou penais, visto que, nesse caso, o Parlamento atuaria como verdadeiro legislador ${ }^{343}$.

Aliás, teria sido exatamente o abuso dessas prerrogativas que teria levado o legislador a vedar a utilização da lei orçamentária como instrumento para modificações alheias ao conteúdo das receitas e despesas, fenômeno conhecido entre nós como caudas orçamentárias ou orçamentos rabilongos ${ }^{344}$.

Ao lado do Orçamento das Receitas, Duguit examina o Orçamento das Despesas, buscando aferir a natureza jurídica dessa parte do Orçamento. Para tanto, considera, como Laband, que o Orçamento esteja condicionado pela legislação existente.

Duguit afirmará, nesse aspecto, que o Orçamento das Despesas não é um ato legislativo do ponto de vista material, mas, tão-somente, um ato administrativo

341 "la partie du budget qui fixe les impôts est une loi matérielle, parce que l'impôt n'étant établi que pour un an, la loi budgétaire crée l'impôt à nouveau”. DUGUIT, Léon, op. cit., p. 438.

${ }^{342}$ Nos exatos termos de Duguit: "Jèze critique cette solution (...). Il estime que la décision de la loi du budget n'est en réalité que la condition de l'application de la loi d'impôt, la condition de la naissance de la compétence des fonctionnaires chargés d'établir et de lever l'impôt. It fait ici l'application de la théorie de l'acte-condition (...). Je ne crois pas que l'opinion de Jèze soit exacte. La decisión budgétaire ne peut pas être la condition de l'application de la loi d'impôt, parce que, à l'expiration de l'année, la loi d'impôt n'existe plus. Elle est comme si elle n'avait jamais été, comme si elle était abrogée et par conséquent la decisión budgétaire la fait renaitre, crée un nouvel impôt. Or, un acte qui crée un nouvel impôt est bien un acte législatif matériel". Ibid., p. 438.

343 "Cependant je crois qu'on ne pouvait en contester la légalité constitutionnelle. La partie du budget qui porte plus particulièrement le nom de loi de finances et qui autorise et règle pour l'année la perception des contributions publiques est une loi au sens matériel (...); le parlement, en la votant, agit vraiment comme législateur; il peut donc constitutionnellement modifier ou supprimer par elle des institutions ou des dispositions établies par une loi”. DUGUIT, Léon, op. cit., p. 438/439.

344 "L'abus prenait un tel développement que le législateur a cru sage de s'imposer à lui-même l'obligation de le faire disparaitre; il a voté l'article 105 de la loi de finances du 30 juillet 1913 qui contient la prohibition suivante: 'Il ne peut être introduit dans la loi de finances que des dispositions visant directement les recettes et les dépenses, à l'exclusion de toutes autres questions'. Pour assurer l'exécution de cette disposition, la chambre a introduit dans son règlement un article $102, \S 2$, ainsi conçu: 'Il ne peut éter introduit dans ces projets de loi (les projets de loi de finances annuels) aucune disposition ne visant pas directement les recettes ou les dépenses". Ibid., p. 440. 
condicionado pela lei. As leis existentes se impõem ao orçamento das despesas. Portanto, o Orçamento das Despesas pode derrogar ou modificar regras gerais existentes ${ }^{345}$.

Em conclusão, toda decisão do Parlamento contendo a abertura de um crédito orçamentário seria corretamente caracterizada como um ato administrativo condição - acte administratif condition ${ }^{346}$. Tal entendimento consagraria o princípio da prévia aprovação das despesas pelo Parlamento ${ }^{347}$. Dessa forma, para que despesas pudessem ser realizadas, haveria a necessidade de observância prévia do referido princípio.

Esse é um ponto do preceito de Duguit em que o próprio doutrinador procura salientar sua divergência ante o entendimento de Laband, relativamente à necessidade de prévia aprovação, pelo Parlamento, das despesas.

De acordo com a doutrina labandiana, o orçamento seria um ato administrativo subordinado à legislação. Ante a falta de aprovação da lei de orçamento, poderiam ser realizadas as despesas necessárias à aplicação das leis existentes, sob a responsabilidade política do Governo. Para Duguit, ao contrário, um princípio essencial ao qual se encontraria submetido o Estado moderno seria justamente o da prévia aprovação das despesas pelo Parlamento. Dessa forma, diante da ausência da aprovação parlamentar, as despesas não poderiam ser legitimamente realizadas ${ }^{348}$.

Da caracterização do orçamento das despesas como ato administrativo condição, decorre uma série de consequências. Algumas delas se encontram diretamente relacionadas aos limites jurídicos que devem ser observados pelo Parlamento no exame do Orçamento, ou seja, em que medida pode o Parlamento modificar a proposta orçamentária encaminhada pelo Poder Executivo.

\footnotetext{
345 "Le vote des dépenses par le parlement compris dans la loi générale des finances n'est pas cependant un acte législatif au point de vue matériel. C'est au point de vue interne un acte administratif, pour lequel le parlement doit rester absolument dans la limite de la loi et ne peut rien faire qui soit contraire à la loi. C'est un acte individuel; il doit rester conforme à la règle générale qu'est la loi, laquelle s'impose au parlement comme à tous tant qu'elle n'est pas modifiée ou abrogée par une autre règle générale". DUGUIT, Léon, op. cit., p. 444.

${ }_{346}$ "Si le vote des crédits budgétaires est (...) un acte administratif condition et un acte individuel, il en résulte nécèssairement qu'il est soumis au principe essentiel de légalité qui domine le droit moderne et d'après lequel un acte individuel, quel qu'il soit, de quelque organe qu'il émane, ne peut être fait que dans la limite de la loi, c'est-à-dire de la disposition par voie générale édictée, par l'organe compétent, principe de légalité matérielle qui ne peut pas, qui ne doit pas recevoir d'exception". Ibid., p. 445.

${ }^{347}$ Ibid., p. 444.

348 "Laband (...) soutenaient que le budget est tout simplement un compte portant sur des recettes et des dépenses à réaliser (...) qu'il est par conséquent un acte purement administratif n'avant aucun rapport avec la législation (...) qu'en l'absence d'une loi du budget, le gouvernement n'est point arrêté, qu'il peut faire toutes les dépenses, mais qu'il engage alors ces dépenses sous sa responsabilité politique. (...)

Une pareille solution n'est certainement pas defendable en France. Elle est impossible dans un pays de démocratie parlementaire comme le nôtre. Certainement elle n'est pas soutenable dans l'Allemagne de la constitution républicaine de 1919 (...) En France, il est de principe essentiel que le gouvernement ne peut engager une dépense d'un centime sans une autorisation du parlement". Ibid., p. 460.
} 
As leis existentes se impõem ao Orçamento. Por isso, o Parlamento não pode modificar ou suprimir, por meio da recusa de créditos orçamentários, leis existentes. Em outras palavras, os créditos a serem inscritos no orçamento devem obediência às leis existentes e, portanto, o Parlamento não pode deixar de consignar os recursos necessários ao cumprimento das obrigações do Estado e ao funcionamento das instituições estatais existentes $^{349}$.

Todavia, mediante a votação das despesas, o Parlamento poderia exercer o controle sobre o Governo e, por consequência, na recusa dos créditos orçamentários, não a ponto de suprimir um serviço público estabelecido pela lei, uma Câmara poderia forçar um Ministro a se retirar ${ }^{350}$.

Ao contrário das despesas decorrentes das leis existentes, Duguit reafirma a plena liberdade do Parlamento em recusar os créditos relativos a despesas novas ou extraordinárias $^{351}$.

O orçamento das despesas encontrava-se dividido para cada ministério, por capítulos, e as Câmaras Legislativas analisavam e votavam separadamente cada capítulo ${ }^{352}$. O esforço das Comissões de Orçamento das Câmaras Legislativas direcionava-se no sentido de uma ampliação da aplicação da regra da especialidade, com a consequente criação de divisões numerosas e precisas acerca da destinação dos créditos orçamentários autorizados $^{353}$. De outro lado, existiam regras disciplinando modificações de créditos, sendo vedado o remanejamento de créditos entre distintos capítulos do Orçamento ${ }^{354}$.

\footnotetext{
349 "Tant que cette loi existe, elle s'impose; le parlement peut assurément la modifier et supprimer les souspréfets en faisant une loi nouvelle, mais il ne peut pas les supprimer en refusant le crédit, parce qu'en votant le crédit, il ne fait pas autre chose qu'un acte administratif, qu'il ne peut faire que conformément à la loi.

Le parlement ne peut pas non plus refuser le crédit nécessaire pour exécuter des obligations contractuelles prises par l'Etat. Les contrats faits par l'Etat font naître à sa charge de véritables obligations, et le parlement ne peut point supprimer ces obligations em refusant le credit nécessaire pour les executer". DUGUIT, Léon, op. cit., p. 446.

350 "Mais le parlement peut-il refuser la partie du budget des dépenses relatives au fonctionnement des services publics établis par des lois? On a vu qu'il ne peut pás refuser um crédit afin de supprimer un service public établi par une loi. Mais d'autre part, il ne faut pas oublier qu'au point de vue des rapports constitutionnels des pouvoirs publics le vote du budget, et particulièrement le vote des dépenses, est le moyen les plus énergique donné au parlement pour exercer son contrôle et son action sur le gouvernement. Par conséquent, si, en refusant les crédits budgétaires, une chambre avait pour but, non point de supprimer un service public établi par une loi, mais de forcer un ministère factieux à se retirer, je crois que le parlement resterait dans la correction constitutionnelle en le faisant". DUGUIT, Léon, op. cit., p. 459.

${ }^{351}$ Ibid., p. 458/459.

${ }^{352}$ Ibid., p. $441 / 442$.

${ }^{353}$ DUGUIT, Léon, op. cit., p. 442.

354 "La régle ressort de l'article 30 de la loi de finances du 16 septembre 1871, combiné avec l'article 56 du décret du 31 mai 1862 sur la comptabilité: 'Le budget est voté par chapitres; aucun virement de crédit ne peut avoir lieu d'un chapitre à un autre' (L. 16 septembre 1871, art. 30). 'Chaque chapitre du budget ne contient que des services corrélatifs ou de même nature' (D. 31 mai 1862, art. 56, rapp. l'art. 53 de la loi de finances du 28 décembre 1895)". Ibid., p. 442.
} 
Duguit examina, ainda, a questão sobre a necessidade de uma autorização provisória (douzièmes provisoires), por parte do Parlamento, para que o Governo possa arrecadar as receitas e executar as despesas no caso de demora na aprovação da Lei de Orçamento $^{355}$.

A crítica que o doutrinador francês desfecha contra tal sistema de autorização provisória refere-se à violação da regra da especialidade, visto que os créditos aprovados provisoriamente não se encontram devidamente especificados ${ }^{356}$.

$\mathrm{Na}$ concepção duguitiana, o Parlamento não enfeixa somente a competência exclusiva de autorização das despesas, mas também o poder de verificar o emprego e utilização dos créditos autorizados ${ }^{357}$. Por meio da lei de contas, as Câmaras exerceriam um efetivo e direto controle sobre o emprego feito pelos Ministros dos fundos colocados à sua disposição, permitindo, inclusive, a responsabilização civil dos Ministros ${ }^{358}$. Nesse ponto, a posição de Duguit seria diferenciada em relação à de Jéze e de Laband.

\footnotetext{
355 "Le gouvernement, ne pouvant ni lever les impôts, ni engager les dépenses sans un vote du parlement, lui demande alors d'y être autorisé provisoirement, c'est àdire en attendant que la loi générale du budget soit votée, pendant un, deux, trois mois ou plus, suivant les cas. Comme le montant des dépenses est ainsi évalué par mois, c'est-à-dire par douzième est ainsi évalué par mois, c'est-à-dire par douzième du montant total des dépenses annuelles, on appelle ce système le système des douzièmes provisoires". DUGUIT, Léon, op. cit., p. 461 .

356 "le système des douzièmes provisoires viole complètement la règle de la spécialité budgetáire, règle essentiellement protectrice. Les crédits sont votés en bloc et c'est le gouvernement qui fait lui-même la répartition par ministères et dans chaque ministère par chapitres". DUGUIT, Léon, op. cit., p. 462/463.

357 "Le parlement n'a pas seulement compétence exclusive pour autoriser les dépenses, il a et il doit avoir encore le pouvoir de vérifier l'emploi qui a été fait des crédits ouverts. C'est une règle qui existe en France depuis la Restauration, que le règlement définitif du budget de chaque exercice doit être voté par le parlement et faire l'objet d'une loi qu'on appelle par abréviation la loi des comptes". Ibid., p. 466.

358 “Théoriquement, le vote de la loi des comptes est une chose très importante. C'est par là que les chambres peuvent exercer un contrôle effectif et direct sur l'emploi par les ministres des fonds mis à leur disposition et mettre en jeu la responsabilité civile des ministres, que j'étudierai plus loin au paragraphe 55 , où je montrerai qu'à diverses reprises la question de la responsabilité civile des ministres s'est posée au moment même où la loi des comptes d'un exercice était soumise au parlement". Ibid., p. 469.
} 


\section{NATUREZA JURÍDICA DA LEI DE ORÇAMENTO NO ORDENAMENTO BRASILEIRO}

O objetivo central deste capítulo é, exatamente, enfrentar a discussão sobre a natureza jurídica da Lei Orçamentária, em consonância o tratamento conferido pelo ordenamento jurídico brasileiro.

Para tanto, foi dividido em doze seções, cada uma das quais examina um tema de particular relevância dentro da abordagem clássica da Lei de Orçamento. Eventualmente, faz-se breve retrospecto aos postulados firmados pelos autores da Teoria Clássica, em face dos quais se procura estabelecer o imprescindível diálogo, considerando o tratamento conferido pelo ordenamento jurídico brasileiro e as linhas teóricas mais modernas desenvolvidas acerca dos temas.

A única seção que foge à regra geral estabelecida é, justamente, a primeira, em que se procura sistematizar o debate brasileiro acerca do Orçamento Mandatório ou Impositivo, dada sua indissociável conexão com a temática da natureza jurídica da lei orçamentária. $\mathrm{O}$ referido tema, embora não seja tratado diretamente pela Teoria Clássica, possui suficiente relevo para ser incluído em nossas investigações.

As demais seções examinam os seguintes temas: i) Unidade e pluralismo na Lei de Orçamento; ii) Metas fiscais e seu conteúdo jurídico; iii) Conteúdo jurídico do Orçamento das Receitas; iv) Conteúdo jurídico do Orçamento das Despesas; v) Conflitos entre objetivos fiscais e objetivos programáticos; vi) Autorização para abertura de créditos suplementares e alterações da Lei de Orçamento; vii) Condicionamento da legislação permanente pelas leis orçamentárias; viii) Limites da atuação do Parlamento na discussão e aprovação da Lei de Orçamento; ix) Infrações à Lei de Orçamento e responsabilização pelo seu descumprimento; x) Validade atual da distinção entre Lei Formal e Lei Material e enquadramento jurídico da Lei de Orçamento no ordenamento brasileiro; e xi) A flexibilidade como elemento integrante da natureza jurídica da Lei de Orçamento. 


\subsection{O Orçamento Impositivo}

Um dos temas que se encontra diretamente associado à discussão da natureza jurídica do Orçamento é, justamente, a controvérsia existente entre o caráter autorizativo ou impositivo da Lei Orçamentária no ordenamento jurídico brasileiro. Essa temática aparece reiteradamente no debate político brasileiro, tendo motivado a criação de inúmeras proposições legislativas, inclusive de emenda constitucional, que contêm dispositivos que introduzem, em graus e de maneiras variadas, a obrigatoriedade da execução dos créditos orçamentários constantes da LOA aprovada pelo Congresso.

O exame do tema requer a prévia delimitação dos contornos e alcance da discussão. De forma geral, quando se admite, no debate brasileiro, o caráter autorizativo da LOA está-se referindo, tão-somente, ao montante de recursos consignados nos créditos orçamentários constantes dela, que representariam, nesse contexto, o teto ou limite máximo de despesas autorizadas. Portanto, a caracterização vulgarmente utilizada da expressão "caráter autorizativo" da lei encontra-se diretamente vinculada aos valores máximos disponibilizados para atuação do Executivo.

Tal concepção está enraizada na cultura brasileira, conforme comprova o amplo espectro de disseminação desse entendimento, que vai desde reportagens e matérias veiculadas pela mídia ${ }^{359}$ até a literatura técnica ${ }^{360}$. Abarca, ainda, discussões havidas no Congresso $^{361}$ e pesquisas acadêmicas ${ }^{362}$ que perpassam o tema.

\footnotetext{
${ }^{359}$ Há material farto desse entendimento veiculado na mídia brasileira. À guiza de exemplo, veja-se o trecho do artigo publicado no Correio da Bahia, em 01.05.2005: "No atual sistema, em que o orçamento é apenas autorizativo, o Executivo pode contingenciar verbas, realizar cortes, não executar a programação aprovada ou executá-la parcialmente, sem sequer comunicar ao Congresso Nacional, tornando, a peça orçamentária uma mera declaração de intenções e abrindo espaço para todo tipo de negociações na luta pela liberação dos recursos". Disponível em [http://www.seplan.ba.gov.br/conteudo.php?ID=750] Acesso em 24.06.2009.

${ }^{360}$ Exemplo das discussões técnicas encontra-se no estudo feito por Selene Peres Nunes: "Como o orçamento tem caráter autorizativo, funciona como um teto para os gastos, permitindo que o Executivo execute valor inferior ao fixado ou que realize liberações próximo ao final do exercício". NUNES, Selene Peres P. A Revisão da Lei $n^{o}$ 4.320/1964 no contexto da Lei de Responsabilidade Fiscal. In: Boletim de Desenvolvimento Fiscal no 05 - IPEA - Instituto de Pesquisa Econômica Aplicada. Jun. 2007, p. 27.

${ }^{361}$ CONGRESSO NACIONAL. Comissão Mista de Planos, Orçamentos Públicos e Fiscalização. Reforma Orçamentária. Sugestões apresentadas pelo Presidente da CMO Deputado Paulo Bernardo relacionadas ao aprimoramento do processo orçamentário, 01 de março de 2005. Disponível em [http://www.forumfbo.org.br/media/reforma\%20or\%C3\%A7ament\%C3\%A1ria.doc]. Acesso em 27.08.2009. 362 A dissertação de mestrado de Luís Otávio Barroso da Graça, na área da Economia Política, aborda a questão: "Um dos temas de debate no que diz respeito à matéria orçamentária relaciona-se à controvérsia sobre o caráter autorizativo da Lei Orçamentária Anual (LOA). A prática brasileira mostra ser a LOA concebida como definidora de valores máximos para cada ação de governo". GRAÇA, Luís Otávio Barroso da. Orçamento Impositivo: uma análise à luz da Economia Política. Dissertação apresentada ao Departamento de Economia da Universidade de Brasília, 2003, p. 06. Disponível em [http://www2.senado.gov.br/bdsf/bitstream/id/88438/1/Or\%c3\%a7amento\%20impositivo.pdf]. Acesso em 24.06.2009.
} 
A extensão desse juízo pode ser vislumbrada, ainda, nos estudos de Fernando Limongi e Argelina Figueiredo, no âmbito da Ciência Política, que cortam a referida temática: "A lei orçamentária é autorizativa; não é mandatória. Isto é, o Executivo necessita de aprovação legislativa para efetuar qualquer gasto, mas não precisa fazer todos os gastos autorizados",363.

Por outro lado, há quem vislumbre estranheza na expressão "autorizativo", visto que estaria associada a uma interpretação que interessa ao Executivo, que precisaria neutralizar o aumento de despesa pelo Congresso. Nesse sentido, Maílson da Nóbrega destaca que:

A idéia do Orçamento "autorizativo" tem duas explicações. Primeira, nossas tradições ibéricas, que nos legaram uma cultura que não valoriza o Orçamento como limite ao arbítrio dos governantes. Segunda, a tradicional irresponsabilidade fiscal do Congresso. Se o Orçamento fosse impositivo, as despesas ficariam incontroláveis ${ }^{364}$.

Há outros posicionamentos que divergem da concepção prevalecente. Regis Fernandes de Oliveira, em artigo intitulado "Deve o Orçamento ser Cumprido?" apresenta instigante questionamento:

\begin{abstract}
A lei orçamentária é aprovada e, logo em seguida, o Chefe do Executivo, em manifesta desconsideração com o que restou aprovado, baixa decreto determinando o contingenciamento (congelamento de gastos). Não caracteriza tal comportamento o descumprimento da lei orçamentária, de forma a fazer incidir a responsabilidade do Presidente? ${ }^{365}$.
\end{abstract}

A conclusão a que chega o jurista é exposta nos termos seguintes:

\begin{abstract}
"A título de conclusão, pode-se afirmar que o orçamento é impositivo, não deixando margem a manobras, titubeios ou qualquer tergiversação do Governo, a pretexto de utilizá-lo como meramente autorizativo. Contém autorizações, com certeza, na arrecadação, mas as despesas devem ser efetuadas de acordo com o que foi determinado na lei orçamentária”366.
\end{abstract}

Giacomoni também aborda a questão da controvérsia sobre o caráter autorizativo da Lei Orçamentária e termina por ligar esse tema à questão da natureza jurídica do

\footnotetext{
${ }^{363}$ FIGUEIREDO, Argelina Cheibub; LIMONGI, Fernando. Incentivos Eleitorais, Partidos e Política Orçamentária. DADOS - Revista de Ciências Sociais, Rio de Janeiro, v. 45, n. 2, 2002, p. 314/315.

${ }^{364}$ NÓBREGA, Maílson da. Orçamento já é impositivo. Artigo publicado no Jornal O Globo. Disponível em [http://oglobo.globo.com/pais/noblat/post.asp?cod_Post=60567\&a=112]. Acesso em 24.06.2009.

365 OLIVEIRA, Regis Fernandes de. Deve o Orçamento ser Cumprido?. Jus Navigandi, Teresina, ano 9, n. 672, 8 maio 2005. Disponível em: <http://jus2.uol.com.br/doutrina/texto.asp?id=6698>. Acesso em: 28 ago. 2009.

${ }^{366}$ Ibid.
} 
Orçamento $^{367}$. Na visão do autor, três são os motivos que acarretam a não execução de parte dos créditos previamente consignados na peça orçamentária:

$1^{\circ}$ ) a própria natureza dos créditos orçamentários, visto que "os créditos distinguemse entre si quanto à obrigatoriedade de sua realização, em consequência da existência, ou não, de leis - e da natureza destas - criadoras de direitos e obrigações para o Estado"368;

$2^{\circ}$ ) a natureza da programação de trabalho ou plano administrativo, que demanda uma certa flexibilidade; e

$3^{\circ}$ ) a ocorrência de situações variadas que acarretam atrasos no início e conclusão das programações orçamentárias. Nesse caso, como destaca Giacomoni, "são muitas as providências desenvolvidas entre a fase da autorização orçamentária e a realização propriamente dita da despesa. Podem-se apontar algumas: elaboração de projetos, orçamentos e memoriais de execução, desapropriações, fase licitatória com frequentes atrasos em face das querelas judiciais, elaboração de contratos, entre outras"369.

No contexto da ampla aceitação do caráter autorizativo, ao Poder Executivo restaria assegurada certa margem de discricionariedade quando da execução do Orçamento previamente aprovado. Tal fato ensejaria a possibilidade de execução a menor dos valores máximos constantes dos créditos orçamentários ou, no limite, da não execução de qualquer parte dos recursos atribuídos na LOA.

Essa circunstância, associada aos contingenciamentos levados a efeito pelo Poder Executivo para assegurar o alcance das metas fiscais fixadas, importaria na não execução de parcela das emendas parlamentares incluídas quando da votação e aprovação da LOA. Além disso, aproveitando-se deste caráter autorizativo, o Executivo terminaria por condicionar liberações de recursos para o atendimento das demandas parlamentares à aprovação de projetos de seu interesse no Congresso Nacional, com a institucionalização de um padrão altamente criticável de comportamento nas relações entre Executivo eLegislativo no cenário político nacional.

Nesse sentido, as análises feitas por Helio Tollini e José Roberto Rodrigues Afonso, respectivamente, ilustram a celeuma acerca do tema:

(...) a existência das emendas individuais tem interessado tanto ao Poder Legislativo quanto ao Poder Executivo. Enquanto os parlamentares beneficiam-se politicamente com a possibilidade de destinar recursos federais para as suas bases eleitorais, o Poder Executivo utiliza as emendas como mecanismo de cooptação em suas relações com os

\footnotetext{
${ }^{367}$ GIACOMONI, James. Orçamento Público. 14ª ed. São Paulo: Atlas, 2007, p. 283.

${ }^{368}$ Ibid., p. 286.

${ }^{369}$ Ibid., p. 287.
} 
partidos políticos, ao aproveitar-se do caráter autorizativo da LOA para condicionar a execução das emendas individuais à votação pelos parlamentares dos projetos de interesse do Executivo nas votações do Congresso Nacional ${ }^{370}$.

(...) prática política clientelista nas relações entre parlamentares e governo, em que os primeiros votam matérias de interesse do segundo, somente após terem suas reivindicações atendidas. Como fruto dessa assimetria de informação, compromete-se qualquer critério objetivo que se tente usar como regra para a inclusão de projetos no orçamento. A inclusão e a liberação de verbas no orçamento ficam sujeitas apenas a critérios políticos ${ }^{371}$.

Sem entrar no mérito dessas questões, que demandariam mais acurada análise e fogem ao objeto principal deste estudo, deve-se ressaltar que tal posicionamento é objeto de intensa discussão na comunidade acadêmica. Acerca desse debate, a título de ilustração cabem algumas referências importantes.

O tema da execução das emendas individuais dos congressistas como mecanismo de controle utilizado pelo Executivo tem sido objeto de exames por parte dos Cientistas Sociais, a exemplo do trabalho de Pereira e Mueller ${ }^{372}$. Os autores procuraram oferecer evidências empíricas de que o Executivo utilizaria estrategicamente a execução do orçamento como um dos mais importantes instrumentos de barganha na negociação do apoio do Congresso ${ }^{373}$.

No entanto, há estudos que apontam noutro sentido. Para Figueiredo e Limongi, “os cortes das emendas individuais (...) segue menos uma lógica política e mais a macroeconômica. Por essa mesma razão, a própria execução da proposta do Executivo em relação a gastos com investimentos se vê prejudicada",374. Além disso, os pesquisadores questionam a relação entre liberação de recursos para execução das dotações previstas nas

\footnotetext{
${ }^{370}$ TOLLINI, Helio. Em Busca de uma Participação mais Efetiva do Congresso no Processo de Elaboração

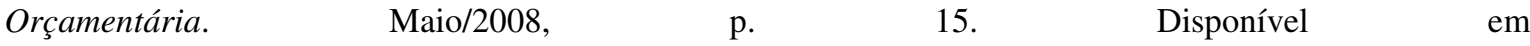
[http://apache.camara.gov.br/portal/arquivos/Camara/internet/orcamentobrasil/orcamentouniao/estudos/2008/ $2 \% 20$ Em\%20Busca\%20de\%20uma\%20Participa\%C3\%A7\%C3\%A3o\%20mais\%20Efetiva\%20do\%20Congr esso\%20no\%20\%E2\%80\%A6.pdf]. Acesso em 25.06.2009.

371 AFONSO, José Roberto R.; BARROSO, Rafael. Uma Reforma Esquecida. In: Boletim de Desenvolvimento Fiscal no 05 - IPEA - Instituto de Pesquisa Econômica Aplicada. Jun. 2007, p. 12/13.

${ }^{372}$ PEREIRA, Carlos; MUELLER, Bernardo. Comportamento Estratégico em Presidencialismo de Coalizão: As Relações entre Executivo e Legislativo na Elaboração do Orçamento Brasileiro. DADOS - Revista de Ciências Sociais, Rio de Janeiro, v. 45, n. 2, 2002, pp. 265 a 301.

${ }^{373}$ Segundo Pereira e Mueller, "As evidências apresentadas neste artigo demonstram que o presidente da República recompensa os parlamentares que sistematicamente votam a favor dos projetos de interesse do governo, autorizando a execução de suas emendas individuais, e, ao mesmo tempo, pune os que não votam nesses projetos simplesmente não executando as emendas propostas por eles". Cf. PEREIRA, Carlos; MUELLER, Bernardo, op. cit., p. 274.

${ }^{374}$ FIGUEIREDO, Argelina Cheibub; LIMONGI, Fernando. Incentivos Eleitorais, Partidos e Política Orçamentária. DADOS - Revista de Ciências Sociais, Rio de Janeiro, v. 45, n. 2, 2002, p. 325.
} 
emendas individuais e o apoio ao Executivo, conforme sugerido com insistência pela imprensa e parte da comunidade acadêmica:

a despeito dessa suspeição, dado o papel que normalmente se atribui à liberação de recursos por meio de emendas individuais nas relações entre Executivo e Legislativo, examinamos a fundo a tese de que votos seriam trocados por execução de emendas, mostrando que não é possível estabelecer a relação causal pretendida. (...) Emendas são executadas sem que os votos esperados sejam dados, e votos são dados sem que a contrapartida - ou seja, a liberação de recursos - ocorra ${ }^{375}$.

Essa questão foi objeto, inclusive, de auditoria realizada pelo mais alta Corte de Contas do país, em decorrência de representação formulada pelo Procurador-Geral do Ministério Público junto ao Tribunal de Contas da União (TCU), acerca da execução das emendas de autoria dos membros do Congresso Nacional ao Orçamento Geral da União OGU e inseridas na LOA para o exercício de 2004. Na representação mencionou-se que,

recentemente, quando da polêmica votação do salário mínimo no dia 2 de junho, o governo federal promoveu acintosa liberação de recursos. Estes fatos evidenciariam o caráter eminentemente político de que, por vezes, se reveste a emissão de empenhos no âmbito do governo federal, tendo por nítido propósito influenciar discussões em curso no Congresso Nacional para a aprovação de projetos de grande interesse do Poder Executivo $^{376}$

Realizada auditoria, com vistas à apuração dos fatos noticiados, o voto do Ministro-

Relator do TCU, em 3 de outubro de 2007, foi no seguinte sentido:

Consoante constatou a Semag no amplo levantamento que realizou, nos períodos de votações importantes há, efetivamente, um incremento das liberações de recursos relativos a emendas de parlamentares do Congresso Nacional. Entretanto, não é possível afirmar que esses incrementos se constituem em expediente utilizado pelo governo federal com a intenção de influenciar na apreciação e votação de proposições de seu interesse em tramitação nas casas legislativas.

Diversos outros fatores podem ter contribuído no fluxo de liberação de recursos, tais como período do mês, encerramento do exercício, contingenciamento de recursos, disponibilidade de caixa da Secretaria do Tesouro Nacional e, especificamente quanto ao exercício de 2004, o período de noventa dias anteriores às eleições daquele ano. Além disso, com pequenas variações, a liberação de recursos acima da média beneficiaram tanto emendas de parlamentares que votaram com o governo como aqueles que votaram contra, não votaram ou se abstiveram ${ }^{377}$.

${ }^{375}$ FIGUEIREDO, Argelina; LIMONGI, Fernando. Processo Orçamentário e Comportamento Legislativo: Emendas Individuais, Apoio ao Executivo e Programas de Governo. DADOS - Revista de Ciências Sociais, Rio de Janeiro, vol. 48, $\mathrm{n}^{\circ}$ 4, 2005, p. 740.

376 TRIBUNAL DE CONTAS DA UNIÃO - TC-009.509/2004-7 - Representação acerca da execução de emendas de autoria de membros do Congresso Nacional ao Orçamento Geral da União. Disponível em [http://www.tcu.gov.br/Consultas/Juris/Docs/judoc/Acord/20071004/TC-009-509-2004-7.doc]. Acesso em 08.06.2009.

377 TRIBUNAL DE CONTAS DA UNIÃO - TC-009.509/2004-7 - Representação acerca da execução de emendas de autoria de membros do Congresso Nacional ao Orçamento Geral da União. Disponível em 
Pondo-se de lado a questão da existência, ou não, de relação direta entre apoio ao Executivo e liberação de emendas parlamentares, o fato é que o caráter autorizativo da lei orçamentária, entendimento majoritário em nosso meio, motivou a apresentação de diversas proposições legislativas que procuraram introduzir, no ordenamento jurídico brasileiro, a figura do que se convencionou chamar de orçamento impositivo, principalmente com vistas a garantir a execução das emendas parlamentares inseridas na Lei Orçamentária. Para Tollini:

\begin{abstract}
Muitos parlamentares insistem na implementação do caráter obrigatório da execução orçamentária, ora para todo o conjunto das despesas, ora apenas para aquelas oriundas de emendas parlamentares. Alguns ignoram os pré-requisitos de ordem fiscal e técnica para que tal obrigatoriedade possa ser implementada sem que o caos se instale. Outros os conhecem, mas fazem coro aos demais, possivelmente na tentativa de pressionar o Poder Executivo por maiores liberações para suas emendas ${ }^{378}$.
\end{abstract}

No mesmo sentido, o estudo de Luís Otávio Barroso da Graça aponta que:

Uma questão que tem hoje recebido severas críticas está relacionada à liberação de verbas das emendas de deputados e senadores pelo Poder Executivo. Como este não tem obrigação de executar determinadas ações, têm os parlamentares que solicitar o atendimento dos projetos para os quais destinaram recursos por meio de emendas. Alguns entendem que tais solicitações, conhecidas por 'barganhas', retiram autonomia do Poder Legislativo e o colocam em situação de inferioridade frente ao Executivo. A adoção do orçamento impositivo (no todo ou em parte), portanto, tenderia a resolver essa situação, na medida em que não restaria ao Poder Executivo outra solução que não a de executar as emendas dos parlamentares ${ }^{379}$.

Dessa forma, em termos gerais, pode-se situar a temática do orçamento autorizativo no bojo da disputa existente entre Poder Executivo e Poder Legislativo, relativamente à matéria orçamentária. O tema não é novo e já foi objeto de discussão em vários projetos de lei e propostas de emendas constitucionais que versam sobre isso.

Surge, por conseguinte, a necessidade de se examinar o delineamento pretendido para o Orçamento Impositivo. Para tanto, é imprescindível a análise de algumas das várias iniciativas do legislador, para a devida caracterização e delimitação dos contornos pretendidos para o Orçamento Impositivo.

Uma das primeiras proposições legislativas que, indiretamente, terminou por abordar o tema do Orçamento Impositivo, foi o Projeto de Lei Complementar n ${ }^{\circ}$ 135/96

[http://www.tcu.gov.br/Consultas/Juris/Docs/judoc/Acord/20071004/TC-009-509-2004-7.doc]. Acesso em 08.06.2009.

378 TOLLINI, Helio, op. cit., p. 37.

${ }^{379}$ GRAÇA, Luís Otávio Barroso da, op. cit., p. 11/12. 
(projeto de alteração da Lei no 4.320/64). O substitutivo ao PLC ${ }^{\circ}$ 135/96 da Comissão de Constituição e Justiça e de Cidadania, de 2008, trata, em seu art. 88, da anulação de créditos orçamentários, nos termos seguintes:

Art. 88. O Poder Executivo deverá solicitar, mediante projeto de lei, a anulação de crédito orçamentário relativo a projeto que não pretenda executar no exercício.

$\S 1^{\circ}$ Os créditos orçamentários relativos a projetos, não anulados nos termos deste artigo, serão reabertos no exercício subsequente, nos limites de seus saldos apurados no dia 31 de dezembro.

$\S 2^{\circ}$ Em caso de crédito reaberto, havendo dotação para o mesmo projeto no orçamento vigente, prevalecerá como dotação autorizada aquela de maior valor.

$\S 3^{\circ} \mathrm{O}$ ato de reabertura dos créditos de que trata o $\S 1^{\circ}$ deste artigo indicará os recursos para atender as despesas, admitidos os previstos no $\S 1^{\circ}$ do art. 85, sendo que a utilização dos recursos provenientes de cancelamento de dotações orçamentárias dependerá de autorização legislativa.

Além disso, o artigo 92 do substitutivo ao PLC n 135/96, inserido na Seção V - Da Apreciação das Leis de abertura de créditos adicionais ou de anulação de créditos orçamentários, previu que:

Art. 92. Os projetos de lei de abertura de créditos adicionais e de anulação de créditos orçamentários deverão ser apreciados pelo Poder Legislativo no prazo máximo de quarenta e cinco dias.

$\S 1^{\circ} \mathrm{Na}$ apreciação dos projetos de lei de que trata esta seção deverão ser observadas as disposições dos artigos 56 e 57.

$\S 2^{\circ}$ Ultrapassando o prazo estabelecido no 'caput', a matéria será incluída na ordem do dia, com convocação diária de sessões, para que se ultime a votação.

Constata-se, nessa versão legislativa, que se pretende dotar a execução orçamentária, em princípio, de um caráter obrigatório. Para que o Poder Executivo possa deixar de executar o crédito, tal como previsto na Lei Orçamentária, deverá encaminhar ao Congresso Nacional um projeto de lei de anulação, relativamente ao montante de recursos autorizados que não pretenda executar no exercício financeiro correspondente.

Por outro lado, há um prazo máximo de apreciação do projeto de anulação de créditos orçamentários, qual seja, 45 dias, findo o qual deverá ser incluído na ordem do dia para a devida deliberação.

A Proposta de Emenda à Constituição no 22/2000, de autoria do Senador Antônio Carlos Magalhães, posteriormente renumerada, na Câmara dos Deputados, como PEC $\mathrm{n}^{\circ}$ 565/06, altera disposições da Constituição Federal, tornando de execução obrigatória a 
programação constante da LOA. Para tanto, foi sugerida a inclusão do art. 165-A, no texto constitucional, nos termos seguintes ${ }^{380}$ :

Art. 165-A. A programação constante da lei orçamentária anual é de execução obrigatória, salvo se aprovada, pelo Congresso Nacional, solicitação, de iniciativa exclusiva do Presidente da República, para cancelamento ou contingenciamento, total ou parcial, de dotação.

$\S 1^{\circ}$ A solicitação de que trata o caput deste artigo somente poderá ser formulada até cento e vinte dias antes do encerramento da sessão legislativa e será acompanhada de pormenorizada justificativa das razões de natureza técnica, econômico-financeira, operacional ou jurídica, que impossibilitem a execução.

$\S 2^{\circ}$ A solicitação poderá, ainda, ser formulada a qualquer tempo, nas situações que afetem negativamente a arrecadação da receita, de calamidade pública de grandes proporções, ou ainda nas previstas no art. 137, inciso II.

$\S 3^{\circ}$ Em qualquer das hipóteses, as solicitações tramitarão no Congresso Nacional em regime de urgência.

$\S 4^{\circ}$ Não havendo deliberação do Congresso Nacional, no prazo de trinta dias, a solicitação será considerada aprovada.

$\S 5^{\circ}$ A não execução de programação orçamentária, nas condições previstas neste artigo, implica crime de responsabilidade.

$\S 6^{\circ}$ Do projeto de lei orçamentária anual, bem como do autógrafo encaminhado para sanção do Presidente da República, não constarão receitas cujas leis que as autorizem tenham o início de vigência posterior à data prevista no inciso III do $\S 6^{\circ}$ do art. 166 .

Na justificativa apresentada conjuntamente com a proposição, extrai-se a fundamentação para tal alteração por parte dos próprios legisladores:

Existe inegável consenso e forte sentimento, no âmbito do Congresso Nacional, da necessidade de se proceder a importantes alterações nas regras constitucionais relacionadas com as matérias orçamentárias.

Apoiado nessa realidade, e buscando responder o sentimento de mudanças, recorremos à Consultoria de Orçamentos, Fiscalização e Controle do Senado para viabilizar tecnicamente proposta de emenda à Constituição que consubstancie as alterações necessárias, de modo a minimizar o viés existente, sobre o assunto, em favor do Poder Executivo.

Nesta oportunidade, estamos submetendo à consideração dos nobres Pares, com o apoiamento constitucional e regimental, o resultado do trabalho dos nossos técnicos, materializado na presente proposta de emenda à Constituição. Com ela buscamos inserir no texto da nossa Lei Maior princípios e regras que coíbam a ditadura do Poder Executivo em matéria orçamentária e, ao mesmo tempo, prestem-se ao aperfeiçoamento do processo orçamentário brasileiro ${ }^{381}$.

Por longa que seja, torna-se necessária a transcrição da justificativa apresentada para a inclusão da referida mudança legislativa em nosso ordenamento:

\footnotetext{
380 SENADO FEDERAL. Proposta de Emenda à Constituição n ${ }^{\circ}$ 22, de 2000, p. 01/02. Disponível em [http://www.senado.gov.br/sf/atividade/materia/getPDF.asp?t=41011] Acesso em 25.06.2009.

381 SENADO FEDERAL. Justificação da Proposta de Emenda à Constituição n ${ }^{\circ}$ 22, de 2000, p. 02. Disponível em [http://www.senado.gov.br/sf/atividade/materia/getPDF.asp?t=41011] Acesso em 25.06.2009.
} 
As nossas leis orçamentárias, tal como vêm sendo postas em prática, não passam de uma grande ficção. Pouco, ou nada, valem os esforços de mobilização dos órgãos competentes para montagem de um projeto coerente a ser encaminhado ao Congresso Nacional; o tempo despendido pelas lideranças partidárias em intermináveis negociações para conciliar os justos e legítimos pleitos das bancadas com assento no Congresso Nacional, nada disso é levado em consideração pelo Poder Executivo na hora de executar a programação orçamentária aprovada pelo Congresso Nacional.

$\mathrm{Na}$ verdade, essa programação muitas vezes tem se prestado como instrumento de barganha política. Isso ocorre, na medida em que a definição do que realmente deve ser executado depende do crivo da zelosa equipe econômica do governo.

É até compreensível e aceitável que as autoridades econômicas primem pelo uso do poder discricionário para ajustar a programação do orçamento aos meios disponíveis para executá-la. Entretanto, quando o uso dessa faculdade transforma em arbitrário o poder discricionário ela realmente se torna insuportável, pois hipertrofia os poderes de Ministros - ou de simples burocratas - submetendo as decisões do Congresso Nacional aos desígnios desses mesmos agentes públicos.

$\mathrm{Na}$ sua origem, as leis orçamentárias constituem instrumento de controle político do Poder Legislativo sobre o Poder Executivo. É do Poder Legislativo a competência privativa para autorizar, em nome da sociedade, o Poder Executivo a arrecadar as receitas - criadas em lei - e a realizar as despesas necessárias ao funcionamento dos serviços públicos e outras que visem ao bem-estar coletivo. Logo, o programa de trabalho do Governo consubstanciado na lei orçamentária anual, em vez de apresentar uma visão unilateral, expressa no documento encaminhado pelo Poder Executivo, deve ser temperado com componente que consigne a visão do Poder Legislativo, refletindo, no conjunto, o compromisso de ambos os Poderes com a Nação.

Se isso não ocorrer, nos deparamos com pelo menos duas situações igualmente graves: a primeira consiste na usurpação das legítimas atribuições de um dos poderes da República, o que é intolerável num regime de plenitude democrática; a segunda consiste na previsibilidade de as decisões dos agentes públicos, tomadas de forma solitária, se tornarem susceptíveis a influências externas, acopladas a interesses que não condizem com a indispensável lisura e com o bem-estar da coletividade.

É evidente que nada temos a contrapor - nem poderíamos ter - ao zelo com que se deve tratar os recursos públicos. Entretanto, será que esse mesmo zelo não prevalece quando o Poder Executivo tem interesse em aprovar, no Congresso Nacional, projetos que se mostram altamente polêmicos e logo surge a possibilidade de liberação de recursos para execução desta ou daquela obra, sob o argumento de que as reivindicações são meritórias? Acreditamos que sim.

Em razão das distorções observadas estamos sugerindo, na presente proposta de emenda constitucional, a criação de mecanismo para explicitar a natureza mandatória da lei orçamentária anual e, assim, suprir eventual lacuna que dá vezo a interpretação distorcida da lei, como vem ocorrendo.

Naturalmente, não poderíamos deixar de reconhecer que uma série de fatores impedem o Poder Executivo a implementar esta ou aquela programação. Um ciclo de conjuntura adversa que frustre as expectativas de arrecadação; a inadimplência de uma entidade, ou ente federado, na prestação de contas; a falta de apresentação de projetos consistentes para aplicação dos recursos. Todas essas são situações, às quais podemos agregar casos extremados, tais como calamidades públicas de grandes proporções ou declaração de estado de guerra ou resposta a agressão armada estrangeira, que podem obrigar o Poder Executivo dar outra orientação a determinada programação constante da lei orçamentária.

Nessas hipóteses, a proposta prevê que o Poder Executivo enviará ao Congresso Nacional solicitação de cancelamento ou de contingenciamento, total ou parcial, de dotações orçamentárias. Na solicitação devem ficar assentadas as justificativas de natureza técnica, econômico-financeira, operacional ou jurídica da impossibilidade de execução da programação.

É evidente que, em sendo procedentes as razões alinhadas, o Congresso Nacional jamais se furtará em conceder o seu referendum. Esta Casa sempre agiu e agirá em benefício do povo brasileiro.

Essa solicitação, entretanto, deverá ser formulada com antecedência razoável do término do exercício financeiro, para que, em sendo a autorização negada pelo Congresso, haja 
tempo hábil para a realização dos procedimentos administrativos que a lei exige, com vistas à implementação das ações.

Por isso, está sendo proposto, como limite máximo, o prazo de 120 dias, antes do encerramento da sessão legislativa. Não prevalecerá esse prazo, todavia, nas hipóteses de graves crises econômicas como as da Rússia e da Ásia, que ainda estão bem vivas na memória de todos nós, ou mesmo de outra natureza que abalem a paz social. São casos excepcionais e como tal devem ser tratados.

Observe-se que nessa matéria o Congresso não poderá se omitir, haja vista que não havendo deliberação no prazo de trinta dias, a solicitação é tida como aprovada.

Como a eficácia da norma deve estar sempre associada a uma cominação legal, a proposta contempla sanção para as hipóteses de seu descumprimento. Assim, o desrespeito à regra constitucional caracteriza crime de responsabilidade.

$\mathrm{O}$ que se tem em mira é restabelecer o equilíbrio entre os Poderes. As deliberações de um deles não poderão ser anuladas pelo outro.

Nesse passo, cabe realçar que, executar uma programação não tem aqui, necessariamente, o significado de concluir uma obra ou serviço, nem de exaurir uma dotação autorizada. Executar uma programação significa dar andamento às ações, no ritmo que as circunstâncias ditarem, para a obtenção de um bem ou serviço, sem descurar dos princípios básicos de eficiência e da eficácia no emprego dos recursos públicos.

Adicionalmente, o cotejo do instrumento proposto com a experiência internacional é sempre pertinente. O caso dos Estados Unidos da América do Norte aproxima-se bastante da nossa realidade, uma vez que naquele país o sistema de governo é presidencialista - como o nosso - e, igualmente, uma federação.

Lá, sempre o Poder Executivo não pode executar uma programação ou, por razões outras, pretende diferir a execução (executá-la posteriormente), o Presidente da República é obrigado a submeter essa decisão à aprovação de uma das Casas do Congresso, que a acolherá ou rejeitará.

Portanto, trata-se de instrumento perfeitamente ajustado aos princípios democráticos e ao sistema presidencialista de governo.

Para finalizar, lembramos que mantemos a atual possibilidade constitucional de edição de projetos de leis de créditos adicionais (suplementar e especial), de vez que esses instrumentos estão de acordo com as prerrogativas constitucionais do Poder Legislativo de participar da elaboração da peça orçamentária ${ }^{382}$.

A exemplo da versão do PLC no 135/96, a PEC n ${ }^{\circ}$ 22/2000 pretende, em tese, dotar a execução orçamentária de um caráter impositivo, obrigando o Poder Executivo a encaminhar ao Congresso solicitação para cancelamento ou contingenciamento quando não pretenda executar a programação aprovada. As modificações pretendidas buscam inspiração no modelo norte-americano, como a própria justificativa apresentada deixa claro.

Chama a atenção o fato de o legislador realçar que pretende, apenas, explicitar a natureza mandatória de que já se reveste a lei orçamentária, posicionamento contrário ao entendimento geral já estampado. Por outro lado, busca-se justificar a inserção dos dispositivos constitucionais destacando que não se trata de exaurir uma dotação autorizada, mas, sim, dar andamento às ações no ritmo que as circunstâncias ditarem.

382 SENADO FEDERAL. Justificação da Proposta de Emenda à Constituição no 22, de 2000, p. 04/05. Disponível em [http://www.senado.gov.br/sf/atividade/materia/getPDF.asp?t=41011]. Acesso em 25.06.2009. 
Em junho do mesmo ano, nova proposta de emenda constitucional foi apresentada a

PEC no 28/2000, dando nova redação ao caput do art. 166 e acrescentando novo parágrafo ao mesmo artigo da Constituição Federal ${ }^{383}$. O texto proposto passaria a vigorar nos termos seguintes:

Art. 166. Os projetos de lei relativos ao plano plurianual, às diretrizes orçamentárias, ao orçamento anual, aos créditos adicionais e à anulação de créditos serão apreciados pelas duas Casas do Congresso Nacional, na forma do regimento comum.

(...)

$\S 9^{\circ}$ O Presidente da República enviará mensagem ao Congresso Nacional para propor anulação dos créditos orçamentários ou adicionais que não serão executados no decorrer do exercício.

A justificação apresentada pelos parlamentares autores da proposição indica a motivação para a alteração:

A Carta Magna de 1988 concedeu ao Poder Legislativo amplas prerrogativas de participação em todo o ciclo orçamentário, restabeleceu o equilíbrio e promoveu uma sistemática de co-responsabilidade entre os Poderes Executivo e Legislativo na definição das prioridades nacionais e na decisão relativa à alocação dos recursos públicos. Nesse sentido, pode-se afirmar que o Congresso Nacional, ao apreciar os projetos de lei do plano plurianual, das diretrizes orçamentárias e do orçamento anual, não estaria restrito apenas às funções legislativa e de controle, mas a exercer um relevante papel nas decisões políticas do mais alto interesse para o País.

De fato, ao apreciar os referidos projetos de lei, está o Parlamento livre para modificálos, mediante alterações, ajustes, adequações e correções de erros ou para suprir omissões, ressalvadas apenas as limitações e restrições constitucionais e legais. Porém, em face do caráter vinculado da lei orçamentária, a margem para livre realocação de recursos no processo orçamentário, pelo Congresso Nacional, por meio das emendas individuais, de Bancadas Estaduais e Regionais e de Comissões é significativamente restrita, situada normalmente em menos de $5 \%$ do total.

As nossas leis orçamentárias, tal como vem sendo postas em prática, não passam de uma grande 'peça de ficção'. Pouco, ou nada, valem os esforços de mobilização dos órgãos competentes para montagem de um projeto coerente a ser encaminhado ao Congresso Nacional. Pouco, ou nada, vale o tempo despendido pelas lideranças partidárias em intermináveis negociações para conciliar os justos e legítimos pleitos das bancadas com assento no Congresso Nacional. Nada disso é levado em consideração pelo Poder Executivo na hora de executar a programação orçamentária aprovada pelo Congresso Nacional.

$\mathrm{Na}$ verdade, a programação orçamentária tem prestado-se mais como instrumento de barganha política do que realmente como instrumento de solução dos graves problemas que afligem nossa população. Quando o Poder Legislativo tem interesse em aprovar, no Congresso Nacional, projetos que se mostram altamente polêmicos, logo surge a possibilidade de liberação de recursos para execução desta ou daquela obra, sob o argumento de que as reivindicações são meritórias. Assim, o Poder Executivo tem executado os orçamentos ao longo dos anos de acordo com seus interesses, relegando a segundo plano - ou mesmo desconsiderando - as prioridades aprovadas pelo Congresso Nacional, particularmente aquelas decorrentes de emendas parlamentares.

Esse procedimento tem resultado em, pelo menos, duas graves distorções: de um lado, faz letra morta a vontade dos congressistas, expressa nas emendas; de outro, torna

383 SENADO FEDERAL. Proposta de Emenda à Constituição no 28, de 2000, p. 01/02. Disponível em [http://www.senado.gov.br/sf/atividade/materia/getPDF.asp?t=40794]. Acesso em 24.06.2009. 
inócua a participação do Congresso Nacional no processo de apreciação e de execução orçamentária, violando a harmonia que deve haver entre os Poderes, na medida em que a prerrogativa parlamentar, embora exercitada, não tem sido efetivamente respeitada.

É certo, não obstante, que todos gostaríamos de ver o Congresso Nacional empenhado de forma mais efetiva no exercício das prerrogativas que lhe confere a Lei Maior nas áreas da formulação de políticas e programas governamentais, alocação dos recursos públicos, controle dos respectivos gastos e avaliação dos resultados obtidos, com enfoque predominante no atendimento das necessidades sociais.

É útil aqui observar a experiência de outros países. Em 1974, o Congresso americano aprovou o Congressional Budgetary and Impoundment Control Act, com objetivo de fortalecer o papel do Poder Legislativo nas decisões orçamentárias. Um dos aspectos motivadores da referida norma foi, em particular, a prática presidencial de reter os recursos necessários para a execução de projetos de interesse dos congressistas. A lei em questão introduziu o mecanismo denominado rescission por meio do qual os créditos orçamentários só deixaram de ser executados após anulação autorizada por uma das Casas do Congresso. Creio que o referido mecanismo pode ser introduzido na norma brasileira com algumas adaptações. É o que estou propondo no projeto que trago à consideração dos nobres Senhores Senadores.

Por seu lado, a lei orgânica de finanças francesa prevê três modalidades de créditos: estimativos, provisionais e limitativos. As duas primeiras modalidades dizem respeito a créditos que atendem despesas amparadas pela lei, portanto, de execução obrigatória. Os demais créditos são limitativos, ou seja, os seus respectivos valores constituem um limite para a realização das despesas correspondentes. A programação dos créditos limitativos poderá ser executada apenas em parte ou, até mesmo, não ser executada.

Em razão disso, com o apoiamento constitucional e regimental, estamos apresentando esta proposta de emenda constitucional (PEC). Defendo que o princípio de que a vedação ao cancelamento de autorizações orçamentárias deve valer para todas as dotações. A eficácia da disposição constitucional aqui proposta dependerá da aprovação de regulamento que discipline temas como a forma de apresentação das propostas de anulação dos créditos, assim como os prazos para a apresentação e para a apreciação das propostas de anulação. Com esse objetivo, estamos propondo a alteração do $\S 9^{\circ}$ do art. 166 da Constituição Federal, estabelecendo que a lei complementar ali prevista disciplinará o cumprimento da nova regra constitucional, de forma que a mesma possa cumprir suas importantes finalidades ${ }^{384}$.

A PEC nº 28/2000 inclui, na Constituição da República, dispositivo em que torna obrigatória a proposição de mensagem visando à anulação dos créditos orçamentários ou adicionais que não serão executados no decorrer do exercício. Trata-se, portanto, de versão mais moderada, em comparação à PEC n ${ }^{\circ}$ 22/2000, que exige solicitação do Presidente da República para cancelamento ou contingenciamento, total ou parcial, de dotação. As duas PECs, a despeito dessas diferenciações no tocante à extensão das condicionantes que introduzem na execução orçamentária, buscam, indiscutivelmente, sua inspiração no modelo orçamentário estadunidense.

Há, ainda, outras versões de Orçamento Impositivo. A PEC nº 24/03, de autoria do Senador Paulo Paim, acrescenta o inciso XII ao art. 167, passando a vedar o "bloqueio ou contingenciamento de dotações do orçamento da seguridade social".

Na justificativa apresentada pelo Senador, em 22 de abril de 2003, tem-se que:

384 SENADO FEDERAL. Proposta de Emenda à Constituição no 28, de 2000, p. 01/02. Disponível em [http://www.senado.gov.br/sf/atividade/materia/getPDF.asp?t=40794]. Acesso em 24.06.2009. 
o entendimento, implantado no âmbito do Poder Executivo, de que o orçamento público é simplesmente indicativo - não tendo portanto sua execução caráter obrigatório, tem levado à banalização da prática de efetuar a retenção de dotações orçamentárias relativas a despesas aprovadas pelo Congresso Nacional, constantes das leis orçamentárias, o que tem causado enormes prejuízos à população brasileira e retardado o resgate da gigantesca dívida social em nosso País ${ }^{385}$.

Por sua vez, foi lavrado parecer favorável da Comissão de Constituição, Justiça e Cidadania, em 8 de outubro de 2008, nos termos que se seguem:

o governo federal, preocupado com o atingimento da meta de superávit primário, vem promovendo sistematicamente limitações de empenho e movimentação financeira, sem falar na desvinculação de $20 \%$ das contribuições sociais prevista no art. 76 do Ato das Disposições Constitucionais Transitórias da Carta Magna. A presente proposição pretende atenuar essa situação, vedando a prática de se impor limites à execução do orçamento da seguridade social, prática que tanto prejuízo gera à saúde, à previdência e à assistência social, o que se reflete diretamente nos serviços prestados à população brasileira $^{386}$.

A versão da PEC no 24/03 procura atribuir caráter obrigatório a somente uma parcela do Orçamento da União: aquela referente ao Orçamento da Seguridade Social.

A mais recente proposta legislativa pertinente à natureza da lei orçamentária tem origem no PLC n ${ }^{\circ}$ 229/09, de autoria do Senador Tasso Jereissati, que também visa à substituição da Lei $n^{\circ}$ 4.320/64, a exemplo do PLC n $n^{\circ}$ 135/96. No art. 79, a proposição deixa patente a intenção de tornar obrigatória a execução das dotações incluídas na LOA por intermédio de emendas parlamentares:

Art. 79. No caso da União, as dotações incluídas na lei orçamentária por intermédio de emenda de bancada ou individual, nos limites indicados pelo art. 50, incisos I e II, desta Lei Complementar, devem ser obrigatoriamente executadas em sua totalidade durante o exercício financeiro.

$\S 1^{\circ}$ Caso se constate não ter havido a plena execução das dotações referidas no caput deste artigo, o balanço orçamentário da União deverá explicitar, caso a caso, as razões para o descumprimento deste artigo, admitidas apenas razões de ordem econômica, técnica ou ambiental.

$\S 2^{\circ}$ Caso o Tribunal de Contas da União considere que a razão alegada pelo Poder Executivo não justifica o descumprimento do disposto no caput deste artigo, o agente público responsável pela execução da despesa será pessoalmente responsabilizado, e passível de punição nos termos da lei orgânica do Tribunal de Contas da União.

\footnotetext{
385 SENADO FEDERAL. Exposição justificativa do Senador Paulo Paim constante da PEC no 24, de 2003. Disponível em [http://www.senado.gov.br/sf/atividade/materia/getPDF.asp?t=39195] Acesso em 24.06.2009.

${ }^{386}$ SENADO FEDERAL. Parecer n ${ }^{\circ}$ 1.061, de 08.10.2008, da Comissão de Constituição, Justiça e Cidadania, referente à PEC $\mathrm{n}^{\mathrm{o}} 24 / 2003, \quad$ p. $02 . \quad$ Arquivo disponível em [http://www.senado.gov.br/sf/atividade/materia/getPDF.asp?t=22277]. Acesso em 24.06.2009.
} 
A questão da adoção do instituto rescission, oriundo da sistemática norteamericana, não passou despercebida na análise de Giacomoni, que apresentou seu posicionamento quanto à pertinência da questão:

\begin{abstract}
Em primeiro lugar, recomenda-se estudar a oportunidade de transplantar, para a norma brasileira, o equivalente ao rescission, regra em vigor na sistemática orçamentária norteamericana, que exige a autorização legislativa para a anulação, parcial ou total, de créditos orçamentários. No Brasil, com base na autorização genérica que, tradicionalmente, consta da lei orçamentária, o Poder Executivo abre créditos suplementares, utilizando como recurso o cancelamento de outros créditos. No âmbito do orçamento federal, tem sido autorizada a anulação de $20 \%$ de cada dotação, significando importante transferência de poder de discrição ao Poder Executivo. Com a adoção do rescission, todo e qualquer cancelamento passaria a depender de prévia autorização legislativa.

A adoção dessa alternativa deveria ser precedida de cuidadosa avaliação, pois a autonomia que aquela margem concede ao Executivo é um importante elemento do princípio da flexibilidade anteriormente analisado. Para cassar o referido benefício, o Poder Legislativo deveria estar amplamente capacitado a apreciar e aprovar com celeridade as inúmeras solicitações de créditos suplementares que passariam a ser feitas $^{387}$.
\end{abstract}

Em síntese, não divergem muito as propostas legislativas relativamente à introdução do chamado Orçamento Impositivo. Tratam, em maior ou menor grau, de atribuir obrigatoriedade à execução dos créditos orçamentários constantes da Lei Orçamentária aprovada pelo Parlamento.

Para que o Executivo, na condução da execução orçamentária, possa deixar de executar os créditos orçamentários, tais como previstos, deverá encaminhar uma mensagem, um projeto de lei ou uma proposta de anulação ou contingenciamento dos créditos autorizados à deliberação parlamentar. Os créditos orçamentários passam a ser, em princípio, obrigatórios.

Os institutos que inspiraram a elaboração das proposições legislativas mencionadas foram o rescission e o deferral, muito embora as justificativas parlamentares brasileiras somente mencionem o primeiro mecanismo.

Dentro do modelo estadunidense, esses institutos funcionam de forma complementar: enquanto que o rescission é uma espécie de cancelamento ou anulação de créditos, o deferral é uma modalidade de congelamento ou contingenciamento provisório de créditos orçamentários.

O cancelamento ou a anulação de créditos - rescission -, por ter um caráter permanente, somente será efetivado caso o Congresso norte-americano aprove um projeto

${ }^{387}$ GIACOMONI, James. Orçamento Público. 14a ed. São Paulo: Atlas, 2007, p. 289. 
de lei - rescission bill -; o deferral, ao contrário, presume-se aceito, a menos que o Congresso adote uma resolução - impoundment resolution - manifestando-se de forma contrária à proposta presidencial. Em ambos os casos, o Congresso deverá ser informado acerca dos montantes, programas e dotações afetadas para conhecimento e deliberação.

Para que se torne possível um exame proveitoso da questão colocada entre nós, há que se desfazer uma imprecisão conceitual. Há uma grande confusão entre a natureza das dotações orçamentárias, no modelo brasileiro, e a tradicional diferenciação entre despesas obrigatórias e despesas discricionárias. Em função disso, existe um entendimento geral, na doutrina, de que haveria uma correlação entre a natureza da despesa e a natureza dos créditos orçamentários e respectivas dotações. Importa esclarecer tal questão.

Antes, porém, faz-se necessário destacar a diferenciação existente entre créditos orçamentários e dotações. Os créditos representam as categorias classificatórias de acordo com as quais a despesa é discriminada, de forma mais ou menos detalhada, no Orçamento. Por sua vez, a cada crédito orçamentário são consignados recursos, conhecidos como dotações. Nas palavras de Giacomoni:

\begin{abstract}
A lei orçamentária é organizada na forma de créditos orçamentários, aos quais estão consignadas dotações. Em conseqüência da imprecisão com que são utilizadas na legislação, é comum o emprego das expressões crédito orçamentário e dotação como sinônimos. Na realidade, o crédito orçamentário é constituído pelo conjunto de categorias classificatórias e contas que especificam as ações e operações autorizadas pela lei orçamentária. No âmbito do orçamento federal brasileiro, a partir do exercício de 2000, o crédito orçamentário individualizado compreende o seguinte conjunto de categorias classificatórias presentes na lei orçamentária: Grupo de Despesa, Identificador de Uso, Fonte de Recursos, Modalidade de Aplicação, Categoria Econômica, Subtítulo, Projeto ou Atividade ou Operação Especial, Programa, Função, Unidade Orçamentária e Órgão. Por seu turno, dotação é o montante de recursos financeiros com que conta o crédito orçamentário ${ }^{388}$.
\end{abstract}

As despesas públicas podem, efetivamente, ser classificadas em obrigatórias ou discricionárias, em função da existência de dispositivos constitucionais ou de leis anteriores que as determinem, ou não.

Todavia, o fato de ter sido atribuída uma dotação a um crédito que se vincule ao pagamento de benefícios instituídos por lei a uma categoria de indivíduos, despesa obrigatória, portanto, não transforma a dotação em obrigatória. E isso ocorre por um motivo muito simples: quando da feitura da lei orçamentária não existe um número exato e preciso acerca da quantidade de indivíduos que preencham os requisitos legais necessários à concessão do benefício. Em consequência, o volume de recursos necessários ao

${ }^{388}$ GIACOMONI, James. Orçamento Público. 14a ed. São Paulo: Atlas, 2007, p. 294. 
pagamento dos benefícios é estimado. Faz-se um cálculo prévio do número de beneficiários a serem contemplados e do montante de recursos necessários.

Durante a execução orçamentária anual, a dotação de um crédito orçamentário vinculado a uma despesa obrigatória poderá se revelar superior ao montante necessário para o cumprimento das obrigações do Estado. Em sentido contrário, poderá requerer uma suplementação de recursos, em face de um número maior de beneficiários do que aquele previsto. Aliás, isto é a regra: o gasto a maior ou a menor do que a estimativa prévia constante da lei, em função de circunstâncias alheias à vontade do administrador público.

Tome-se como exemplo a Lei $\mathrm{n}^{\circ} 7.998 / 90$, que regulamentou o pagamento do seguro-desemprego e disciplinou os requisitos necessários ao trabalhador dispensado sem justa causa para que tenha assegurado o direito à percepção do benefício. De acordo com a referida previsão legal, todos os trabalhadores dispensados sem justa causa, que preencherem as condições estabelecidas pela legislação, terão direito à percepção do benefício.

Para a viabilização do pagamento do seguro-desemprego no ano de 2009, a LOA previu a alocação de recursos orçamentários, no montante de $\mathrm{R} \$ 16.477 .835 .891,00$ ao programa 0099 - Integração das Políticas Públicas de Emprego, Trabalho e Renda, na ação 0583 - Pagamento do Seguro-Desemprego, contemplandoo total de 5.874.745 trabalhadores $^{389}$.

Ainda assim, inúmeras variáveis podem e, com frequência, acarretam um número maior ou menor de beneficiários durante a execução do orçamento. Uma conjuntura adversa em determinado segmento econômico pode implicar uma demissão em massa de trabalhadores, os quais, preenchidos os requisitos da lei, terão assegurado o direito ao recebimento do seguro-desemprego.

Dessa forma, a dotação orçamentária é meramente estimativa, visto que poderá haver mais ou menos trabalhadores pleiteando a concessão do benefício e, portanto, será necessária uma soma maior ou menor de recursos, em conformidade com as circunstâncias reais verificadas. Caso os recursos orçamentários consignados se mostrem insuficientes, será necessário recorrer aos créditos adicionais suplementares para o devido reforço da dotação.

${ }^{389}$ Conforme Lei no 11.897 , de 30.12.2008 (LOA de 2009). Vol. IV - Detalhamento das Ações - Órgãos do Poder Executivo (exclusive Ministério da Educação), p. 358. Disponível em [https://www.portalsof.planejamento.gov.br/sof/2009/VOL_IV.pdf]. Acesso em 01.09.2009. 
Outro exemplo é a Lei $n^{\circ}$ 8.742/93, conhecida como Lei Orgânica de Assistência Social, que instituiu o benefício de prestação continuada, garantindo a percepção de um salário mínimo mensal à pessoa portadora de deficiência e ao idoso com 70 anos ou mais e que comprovem não possuir meios de prover a própria manutenção e nem de tê-la provida por sua família.

Visando o pagamento do referido benefício, na Lei Orçamentária de 2009 foram alocados recursos no programa 1384 - Prestação Social Básica, ação 0575 - Benefício de Prestação Continuada da Assistência Social à Pessoa com Deficiência, no montante de R\$ 8.502.464.791,00 para o atendimento de 1.537.943 pessoas com deficiência ${ }^{390}$.

Entretanto, tal crédito, ligado a uma despesa legal obrigatória, poderá mostrar-se insuficiente para o pagamento de todas as pessoas com deficiência que se encontrem habilitadas à percepção do benefício; ou, ao contrário, poderá indicar excesso de recursos para o pagamento dos beneficiários em determinado exercício financeiro.

Nesses casos, a dotação orçamentária é meramente estimativa, muito embora se encontre relacionada a uma despesa obrigatória. A execução de uma determinada dotação orçamentária não se torna obrigatória por se encontrar vinculada a uma despesa obrigatória. Poderá haver uma execução orçamentária superior ou inferior aos valores inicialmente consignados na LOA, sem que tal ocorrência implique qualquer forma de desrespeito à vontade do legislador ou de discricionariedade por parte do Executivo.

Nesse sentido, não se pode concordar com a afirmação feita por Giacomoni, quando destaca que "os créditos distinguem-se entre si quanto à obrigatoriedade de sua realização, em conseqüência da existência, ou não, de leis - e da natureza destas - criadoras de direitos e obrigações para o Estado"391.

Em síntese: relativamente às despesas obrigatórias, os recursos orçamentários consignados são o resultado de uma estimativa prévia feita pelo Administrador quando da elaboração da Lei Orçamentária. Eles poderão ser executados em montante superior ou inferior àqueles que figuraram no Orçamento em razão da necessidade concreta ditada pelas circunstâncias que determinam o número de beneficiários e o montante de recursos.

\footnotetext{
${ }^{390}$ Conforme Lei n ${ }^{\circ}$ 11.897, de 30.12.2008 (LOA de 2009). Vol. IV - Detalhamento das Ações - Órgãos do Poder Executivo (exclusive Ministério da Educação), p. 712. Disponível em [https://www.portalsof.planejamento.gov.br/sof/2009/VOL_IV.pdf]. Acesso em 01.09.2009.

${ }^{391}$ GIACOMONI, James. Orçamento Público. 14a ed. São Paulo: Atlas, 2007, p. 286.
} 
Considerando-se que, no Orçamento de 2010, cerca de 90,03\% dos recursos previstos referem-se a despesas constitucionais e/ou legais obrigatórias ${ }^{392}$, tem-se uma noção de como funciona a maior parte das dotações orçamentárias da Lei Orçamentária brasileira, que se referem a despesas obrigatórias.

Desse modo, para $90 \%$ do orçamento, os créditos são estimativos. Torná-los artificialmente obrigatórios, por meio de alteração constitucional ou legal, não alterará a sua natureza. Antes, semeará a confusão e a proliferação de entendimentos equivocados em uma seara já bastante complexa.

Resta a discussão: qual a natureza dos créditos que se referem às despesas discricionárias, que não chegam a $10 \%$ do orçamento brasileiro?

A importância da discussão desse tema, relativamente às despesas discricionárias, é inversamente proporcional à participação dessa espécie de despesa na divisão do bolo orçamentário. Exatamente em função deses créditos é que se aventa a possibilidade de criação do chamado Orçamento Impositivo, visto que se trata, no fundo, de garantir a execução das emendas parlamentares, notoriamente no que se refere às despesas relativas a investimentos.

O surgimento das instituições orçamentárias encontra-se indiscutivelmente associado à idéia de autorização, não de obrigação. Justamente por isso, a necessidade de autorização do Parlamento para a arrecadação dos impostos, e, posteriormente, realização das despesas, possuíam a conotação de limite dos gastos dos Monarcas. Destarte, nessa disputa política, o Parlamento aufere o poder de autorizar a arrecadação das receitas e a realização das despesas, controlando a atividade financeira do Estado. Surge, assim, o Orçamento moderno.

Os créditos orçamentários, resultado da progressiva especialização das despesas, surgiram como autorizações. Dessa forma, perfeitamente compreensível a existência de diferença entre os valores consignados no orçamento aprovado e realmente executados.

Retomando Laband: "se considera natural y por encima de toda discusión que el saldo de los ingresos y gastos que, efectivamente, han tenido lugar diferirá de las

\footnotetext{
392 Conforme dados constantes da Apresentação do Orçamento de 2010 realizada pelo Ministro do Planejamento, Orçamento e Gestão, Paulo Bernardo Silva, em 31.08.2009. Disponível em [https://www.portalsof.planejamento.gov.br/sof/2010/Apresentacao_Ministro_2010.pdf]._Acesso em 01.09.2009.
} 
estimaciones establecidas por la ley presupuestaria y que, dada la naturaleza de la materia, tiene que diferir forzosamente. "393

A inclusão de uma dotação na lei orçamentária não implicaria em nenhuma obrigação para que o Governo realizasse o gasto. A efetivação de uma despesa pode ser impossível em alguns casos; em certas hipóteses as funções a serem realizadas pela Administração podem ser alcançadas com custos menores do que aqueles previstos. Em todos esses casos, "sería pura insensatez considerar que el Gobierno está obligado a la prestación de tales gastos por estar previstos en la ley presupuestaria."394

Além disso, poderia haver outras razões de ordem política, econômica e fiscal para que despesas não fossem realizadas, como destaca o célebre Paul Laband:

el Gobierno también puede tener razones de otra especie para omitir unos gastos autorizados en el Presupuesto, especialmente cuando amenazadoras circunstancias políticas exigen la momentánea acumulación de capital o cuando los ingresos son inferiores a los estimados en el Presupuesto, de forma que sea de temer un déficit. ${ }^{395}$

Adicionalmente, Jèze é ainda mais explícito na caracterização dos créditos orçamentários como montantes máximos de gastos:

La autorización parlamentaria (crédito) determina (...) de manera precisa, la suma máxima hasta la concurrencia de la cual el ministro está autorizado para realizar - con determinado objeto - actos jurídicos (contratos) que originen deudas de sumas de dinero a cargo del patrimonio administrativo nacional ${ }^{396}$.

As autorizações concedidas pelo Parlamento - créditos orçamentários - se constituem de três elementos integrantes: i) objeto do gasto; ii) quantia ou soma a ser despendida; e iii) período de tempo em que a despesa pode ser efetivada. O conjunto dessas limitações, de acordo com o direito francês, receberia o nome de especialidade do crédito orçamentário ${ }^{397}$.

Deixando-se de lado as considerações históricas e doutrinárias iniciais acerca do Orçamento Público, na ampla maioria dos ordenamentos jurídicos modernos verifica-se que os créditos orçamentários não são obrigatórios; ao contrário, são sempre recursos máximos colocados à disposição do Executivo.

\footnotetext{
${ }^{393}$ LABAND, Paul. Derecho Presupuestario. Trad. Jose Zamit. Madrid: Instituto de Estudios Fiscales, 1979, p. 90.

${ }^{394}$ Ibid., p. 93.

395 Ibid., p. 93.

396 JÈZE, Gaston. Principios Generales del Derecho Administrativo. Tomo IV. Traducción directa de la $3^{\mathrm{a}}$ edición francesa, por Julio N. San Millán Almagro. Buenos Aires: Editorial Depalma, 1950, p. 16.

397 JÈZE, Gaston, op. cit., p. 15.
} 
O ordenamento francês, nesse tocante, é de uma clareza exemplar. A Lei Orgânica das Leis de Finanças - LOLF deixa assentado que há duas espécies de créditos, em conformidade à nota dominante de que os mesmos se revestem: créditos limitativos e créditos estimativos. Os créditos estimativos seriam, por exemplo, aqueles relacionados aos encargos da dívida do Estado e garantias concedidas ${ }^{398}$.

O ordenamento jurídico chileno estabelece, por meio do art. $9^{\circ}$ do Decreto-lei $n^{\circ}$ 1.263/75, Lei Orgânica de Administração Financeira, que “los presupuestos de gastos son estimaciones del límite máximo a que pueden alcanzar los egresos y compromisos públicos". Dessa forma, as dotações não se configuram como obrigatórias: "The appropriations are considered maximums, i.e. there is not an obligation to spend appropriated funds ${ }^{399}$.

O mesmo ocorre em Portugal. O art. 42 da Lei de Enquadramento Orçamental do Estado (LEOE) destacou que "as dotações constantes do orçamento das despesas constituem o limite máximo a utilizar na realização destas" e que nenhuma despesa poderia ser autorizada ou paga sem que satisfizesse os princípios de economia, eficiência e eficácia.

Mesmo no modelo norte-americano o sentido é o mesmo. A nota que o diferencia é o maior grau de controle do Legislativo sobre as modificações efetuadas pelo Executivo. Deve-se frisar, contudo, que a menor margem de flexibilidade no manejo dos recursos orçamentários, dentro da sistemática norte-americana, não implica em obrigatoriedade de gasto dos montantes consignados, como destacam Blöndal, Kraan e Ruffner:

The flexibility of not spending money is therefore not available to the President as it is in many other OECD member countries (However, agencies are not required to spend all the appropriated monies that have been apportioned to them by OMB, and unspent funds are returned to the Treasury) ${ }^{400}$.

Em vista disso, as despesas discricionárias dos programas são cobertas por meio das dotações anuais concedidas às agências, que se consubstanciam em limites máximos (tetos) de gastos.

Ainda de acordo com a sistemática estadunidense, as despesas obrigatórias, resultantes de leis anteriores que concedem direito a benefícios a grupos e/ou indivíduos,

\footnotetext{
398 "Article 10. Les crédits relatifs aux charges de la dette de l'Etat (...) ont un caractère évaluatif. (...)”.

${ }^{399}$ BLÖNDAL, Jón R.; CURRISTINE, Teresa. Budgeting in Chile. OECD Journal on Budgeting. V. 4, n. 02, 2004, p. 28.

${ }^{400}$ BLÖNDAL, Jón R.; KRAAN, Dirk-Jan; RUFFNER, Michael. Budgeting in the United States. OECD Journal on Budgeting. V. 3, n. 2, 2003, p. 43.
} 
possuem a natureza de apropriações permanentes. Os gastos obrigatórios não são afetados pela lógica do processo de apropriações:

budget authority for many expenditures is not provided in annual appropriations acts. Only discretionary spending, which accounts for only about 35\% of total federal spending, is approved through the annual appropriations process. Appropriations are prepared by programmes within accounts under the heading of each agency ${ }^{401}$.

Dessa maneira, no caso de despesas obrigatórias, não há que se falar em tetos ou limites máximos de gastos, pois falta discricionariedade na determinação dos níveis de gastos com relação àquelas despesas ${ }^{402}$.

Por outro lado, deve-se lembrar que a execução orçamentária é norteada pela incidência dos vetores da eficiência, eficácia e economicidade. Por esse motivo, não há sentido em se obrigar a realização de despesas nos montantes fixados quando há possibilidade de se atingir o mesmo resultado com um volume menor de recursos.

Não há como se obrigar, de forma válida, a que sejam exauridos os recursos constantes da lei orçamentária. Tal entendimento viola frontalmente o espírito constitucional, visto que, sabendo-se da escassez de recursos em face da amplidão das necessidades humanas, determinou que todos os Poderes da República se portassem, na lide com os dinheiros públicos, de modo digno, honrado, valorizando cada unidade monetária consignada para o alcance de objetivos fixados.

Além disso, um sem-número de circunstâncias fáticas pode ocasionar o atraso na execução das atividades previstas na LOA, impedindo ou procrastinando o dispêndio do recurso previsto: lentidão no procedimento licitatório; disputas judiciais envolvendo interessados na contratação com a Administração Pública; problemas relacionados à falta de obtenção das liberações ambientais; paralisação de obras pelos órgãos de Controle Externo, por motivos vários, entre outros.

Existem, ainda, outras condicionantes, a exemplo das metas fiscais estabelecidas na própria Lei Orçamentária como parâmetro para execução de despesas. Assim, a frustração de receitas provoca a necessidade de se impedir a realização de certas despesas, ao menos momentaneamente. Aliás, tais fatos encontram-se previstos na própria legislação pátria, como sugere a leitura do art. $9^{\circ}$ da Lei de Responsabilidade Fiscal.

\footnotetext{
${ }^{401}$ OECD Journal on Budgeting. Special Issue. The Legal Framework for Budget Systems. An Internacional Comparison. V. 4, n. 3, 2004, p. 450.

${ }^{402}$ UNITED STATES. COMMITTEE ON THE BUDGET UNITED STATES SENATE. The Congressional Budget Process - An Explanation. U. S. Government Printing Office: Washington, 1998, p. 5. Disponível em [http://budget.senate.gov/democratic/the_budget_process.pdf]. Acesso em 17.07.2009.
} 
A conclusão a que se chega, portanto, é a de que os créditos orçamentários vinculados a despesas discricionárias possuem um caráter de limites máximos autorizados, no ordenamento jurídico brasileiro. Esse entendimento, ademais, alinha-se com a própria origem da instituição orçamentária e com o juízo em vigor em vários ordenamentos jurídicos estrangeiros.

Desse modo, a discussão com relação ao Orçamento Impositivo é se ele representa uma evolução positiva para a gestão das finanças públicas em nosso ordenamento. Não obstante a introdução de dispositivos como os sugeridos não seja, de qualquer maneira, desejável, foge aos limites deste trabalho uma discussão mais profunda quanto ao mérito do tema.

De acordo com a visão subjacente à temática do Orçamento Mandatório, como posta atualmente, somente por meio da obrigatoriedade dos créditos tornar-se-ia possível vislumbrar obrigatoriedade no orçamento. Contudo, isso não se coaduna com uma análise sistemática do ordenamento jurídico brasileiro, como se procura demonstrar nesta dissertação. Há obrigatoriedade no orçamento, porém, não da forma proposta pelo Orçamento Impositivo.

A título de instigação, pergunta-se: por que não há ninguém que defenda que as metas fiscais previstas na LDO e na LOA sejam meramente autorizativas? A resposta é óbvia: porque as metas fiscais são obrigatórias. Vinculam, assim, o Poder Executivo ao seu alcance, de modo que se deve empreender os esforços necessários no sentido do cumprimento do quanto fixado.

Os objetivos e metas encontram amparo constitucional explícito. A Carta Política da República, ao insculpir as leis orçamentárias, inseriu, em seu código genético, como genes fundamentais, os objetivos e as metas. Tais elementos, derivados diretamente do texto constitucional, expressam a mais íntima conotação de obrigatoriedade de que se podem revestir as LOAs.

A análise feita acerca do caráter autorizativo ou mandatório do Orçamento circunscreveu-se, de acordo com os termos em que se põe o debate, ao conteúdo dos créditos orçamentários. A discussão acerca da natureza da lei orçamentária, nesse contexto, permite que se verifique, em toda a lei, o que se constitui de uma natureza autorizativa e os dispositivos que contêm um cunho obrigatório. Caso se mantenha o foco restrito dos créditos orçamentários, não se torna possível o exame integral da peça orçamentária e de seu sentido em nosso ordenamento. 
Portanto, se se quer dizer, quando se faz referência à natureza autorizativa da lei orçamentária, que esta, relativamente aos créditos orçamentários associados às despesas discricionárias, apenas fixa os limites máximos ou tetos para a realização de despesa, podese admitir como correta a afirmação, em consonância com uma interpretação sistemática do ordenamento brasileiro.

Por outro lado, se se deduz da afirmação da natureza autorizativa da lei orçamentária que nessa não existem, ou não podem existir, dispositivos aos quais se associe um cunho cogente ou obrigatório, não se pode concordar com tal assertiva. E isso ocorre, porque, ao lado das dotações, que apenas indicam os tetos das despesas, existem dispositivos na lei orçamentária com nítido teor obrigatório, a vincular o Administrador Público à sua perseguição e ao seu cumprimento.

Examinando-se a contraparte da natureza autorizativa, ou, por outras palavras, descendo ao exame da natureza mandatória da LOA, verificar-se-á que também se pode admitir, no contexto do atual ordenamento jurídico brasileiro e sem necessidade de qualquer alteração constitucional ou legal, a existência de dispositivos mandatórios ou obrigatórios. Todavia, não se encontram insculpidos nas dotações orçamentárias, que são, tão-somente, estimativas ou limitativas/autorizativas em nosso ordenamento.

Assiste razão, portanto, aos argumentos apresentados pelo debate, dependendo do viés ou ângulo pelo qual se analise a questão. O teor e a extensão do conteúdo obrigatório de que se reveste a lei orçamentária brasileira constituem, exatamente, um dos objetivos pretendidos com a discussão da natureza jurídica da lei orçamentária.

\subsection{Unidade e Pluralismo na Lei de Orçamento}

A Constituição da República prevê, de forma explícita, que a Lei de Orçamento conterá a previsão da receita e a fixação da despesa ${ }^{403}$. Em nosso ordenamento, a Lei Orçamentária, em obediência ao princípio da unidade ${ }^{404}$, consolida, em um corpo normativo único, diversos dispositivos relativos à receita, despesa, autorização para abertura de créditos suplementares e autorização para contratação de operações de crédito.

Dessa forma, o estudo acerca da natureza jurídica da Lei de Orçamento parte do pressuposto de que esta é um todo orgânico, cujos dispositivos e partes integrantes

${ }^{403}$ Art. $165, \S 8^{\circ}, \mathrm{CF} / 88$.

${ }^{404}$ Art. $2^{\circ}$, caput, da Lei $n^{\circ} 4.320 / 64$. 
compõem um único diploma normativo, que somente pode revelar sua natureza jurídica enquanto considerado em sua totalidade. Nas palavras de Fonrouge:

\begin{abstract}
No puede establecerse una separación entre la parte que contiene el plan financiero o los estados de previsión (que sería el acto administrativo) y el texto legal que los aprueba (ley propiamente dicha), porque ambos constituyen fragmentos de un todo orgánico. La ley presupuestaria, pues, es un acto unitario y las cifras de gastos o recursos revisten carácter sustancial e integran el acto mismo; los agregados, cuadros comparativos, etc., cumplen funciones explicativas, pero no son jurídicamente independientes ${ }^{405}$.
\end{abstract}

Efetivamente, as diversas partes que compõem a lei orçamentária não podem, separadamente, revelar a natureza jurídica que deve ser atribuída à lei como um todo. Isso não quer dizer que os diferentes dispositivos inscritos na Lei de Orçamento, ou as partes que identificam um conjunto comum de dispositivos com mesmo sentido, não possuam, se considerados de forma apartada, distinta natureza, visto que existem comandos de graus diversos e com extensão e contornos diferenciados na lei orçamentária.

Todavia, se pode haver uma análise em separado dos dispositivos ou grandes agregados da lei orçamentária, de que são exemplos os capítulos relativos às receitas, às despesas e às autorizações para abertura de créditos suplementares, para que se possa aferir a identidade das partes componentes daquela lei, deve-se salientar que a natureza jurídica da lei orçamentária somente pode se revelar na apreciação conjunta das diversas partes que compõem a Lei.

A importância dessas considerações introdutórias encontra-se diretamente relacionada ao peso das tradicionais análises que procuraram atomizar a lei orçamentária para fins de análise da sua natureza jurídica. Exemplo clássico é a afirmativa de Laband: "La ley presupuestaria consta de dos partes muy distintas entre sí: por un lado, el Presupuesto propiamente dicho, y, por otro, la ley que lo establece ${ }^{\text {,406. }}$.

Não por outro motivo, em tais análises são encontradas afirmações como a seguinte: a lei orçamentária, na parte relativa às receitas, não é efetivamente lei; ou o orçamento das receitas é um mero ato administrativo. Em nosso direito positivo, considerações desse tipo não podem ser convalidadas, pois não há que se falar em "lei de receitas" ou em "lei de despesas".

\footnotetext{
${ }^{405}$ FONROUGE, Carlos M. Giuliani. Derecho Financiero. Vol. I. $3^{\text {a }}$ ed. Buenos Aires: Depalma, 1977, p. $141 / 142$.

${ }^{406}$ LABAND, Paul. Derecho Presupuestario. Trad. Jose Zamit. Madrid: Instituto de Estudios Fiscales, 1979, p. 28.
} 
Os dispositivos relativos às receitas jamais poderiam, por mais que tivessem o condão de renovar a cobrança de impostos, ser qualificados de "lei", de forma apartada do corpo de que se constituem membros componentes. O que pode ser analisado é o quantum de teor jurídico ou o sentido de que se encontrem eventualmente impregnados.

Assim, o que existe é um conjunto de dispositivos, diretamente relacionados, que integram o corpo de uma mesma e única lei. Tais dispositivos compõem, estruturam e dão organicidade à Lei Orçamentária.

A mesma análise não poderia ser feita em ordenamentos forâneos, a exemplo do mexicano, umavez que, naquele país, existem, efetivamente, duas leis distintas: a Lei das Receitas e a Lei das Despesas, muito embora diretamente correlacionadas. Em um caso como este, pode-se, sem sombra de dúvida, proceder a um exame apartado do tratamento jurídico atribuído à Lei das Receitas e à Lei das Despesas. Nosso ordenamento, no entanto, não se coaduna com tal diferenciação.

Essa constatação não impede, contudo, que os diversos dispositivos sejam devidamente esquadrinhados e analisados para que se extraia de cada um deles a sua exata extensão. Efetivamente, a lei orçamentária é um todo orgânico, sem que, por outro lado, deixe de representar a aglutinação de um conglomerado de dispositivos com sentidos e conteúdos diferenciados.

Dessa forma, há, sem dúvida, uma pluralidade normativa na lei orçamentária, que se revela por meio de dispositivos com sentidos diversos: de uns se extraem autorizações; de outros, proibições; existem, ainda, aqueles que consubstanciam obrigações ou determinações. Por vezes, há, em certas partes da lei orçamentária, simultaneamente, autorização e proibição. Há, também, comandos com sentidos diferentes, fato esse que realça a riqueza do exame da Lei de Orçamento.

Em resumo, essas considerações preliminares destacam que a lei orçamentária deve ser considerada como um todo orgânico, que não pode ser retalhado, de modo apriorístico para a detecção de sua natureza jurídica. De outro lado, realça-se o pluralismo normativo de que se encontra impregnada a peça orçamentária, em que são encontrados dispositivos de densidade normativa diferenciada.

Nesse sentido, a Lei Orçamentária é única em sua identidade enquanto diploma normativo, muito embora exista uma pluralidade normativa em sua composição, decorrente da diversidade de comandos constantes da sua natureza. 


\subsection{Metas Fiscais e seu conteúdo jurídico}

O núcleo central da obrigatoriedade insculpida nas peças orçamentárias encontra-se expressamente previsto no texto constitucional brasileiro. Não por outro motivo, o legislador constituinte consignou como o primeiro elemento de cada lei orçamentária os objetivos e as metas. Assim, o Plano Plurianual deverá conter as diretrizes, objetivos e metas da administração pública federal ${ }^{407}$; a Lei de Diretrizes Orçamentárias, as metas $e$ prioridades para o exercício financeiro subsequente; e a Lei Orçamentária, em face da compatibilidade vertical entre os instrumentos, também deverá conter objetivos e metas, que possibilitem a concretização dos fins visados pelo PPA e LDO.

Dessa forma, pode-se sintetizar o principal núcleo obrigatório das leis orçamentárias como sendo os fins a que se destinam. Os fins orientam sua estruturação e lhes conferem direção e sentido, de modo que o administrador público fica vinculado ao alcance dos objetivos e metas fixados, devendo envidar os esforços necessários à plena desincumbência das tarefas que lhe foram cometidas.

Considerando as notas particulares e distintivas existentes entre as funções da Lei do Plano Plurianual, da Lei de Diretrizes Orçamentárias e da Lei Orçamentária Anual, referidos fins assumirão contornos diferenciados, muito embora não percam sua essência: a de serem fins. No caso do PPA, os fins assumem a forma de objetivos estratégicos, mais genéricos e orientadores da elaboração e execução da LDO e LOA; no que se refere à LDO, os fins se consubstanciam em metas fiscais; por sua vez, relativamente à LOA, os fins assumem a forma de objetivos programáticos.

Nesta seção, proceder-se-á ao exame das metas fiscais, tradicionalmente veiculadas por intermédio da Lei de Diretrizes Orçamentárias, muito embora efetivamente concretizadas por meio da execução da Lei de Orçamento anual.

Efetivamente, as leis orçamentárias se encontram revestidas da relevante função de concretização de determinada política fiscal ${ }^{408}$. A atribuição de tal encargo resultou de lenta e progressiva evolução histórica, no contexto do crescimento das funções atribuídas ao Estado, em que objetivos de política fiscal passaram a nortear a condução dos Governos.

\footnotetext{
${ }^{407}$ Art. $165, \S 1^{\circ}, \mathrm{CF} / 88$.

${ }^{408}$ Como destaca Burkhead, "O orçamento é, acertadamente, considerado um instrumento de política fiscal, isto é, um meio de influenciar, deliberadamente, a atividade econômica do país”. BURKHEAD, Jesse. Orçamento Público. Rio de Janeiro: Fundação Getúlio Vargas, 1971, p. 78.
} 
Em nosso ordenamento, nas três peças do ciclo orçamentário - PPA, LDO e LOA são encontrados dispositivos relativos à condução da política fiscal eleita pelo Governo à frente da condução da máquina pública.

Não por outro motivo, a política fiscal para o período do Plano Plurianual também deve se pautar pela diretriz de preservação de resultados fiscais de forma a reduzir os encargos da dívida pública ${ }^{409}$. Por sua vez, as Leis de Diretrizes Orçamentárias trazem dispositivos expressos, fixando a meta fiscal a ser atingida pelo Governo, que se encontra, a seu turno, materializada, de forma concreta, nas proporções estabelecidas entre receitas e despesas primárias previstas na Lei de Orçamento anual.

As leis de diretrizes orçamentárias, que orientam a elaboração e execução das leis orçamentárias anuais, prevêem dispositivos de cunho fiscal desde a instauração da nova ordem constitucional. Portanto, muito antes do advento das regras da Lei de Responsabilidade Fiscal, as LDOs já continham dispositivos expressos fixando os objetivos de caráter fiscal que deveriam nortear a elaboração e execução da Lei de Orçamento.

A Lei no 8.074/90, LDO para 1991, já previa a necessidade da evidenciação da consistência macroeconômica da programação proposta, bem como do cumprimento de um superávit nas contas públicas de $1 \%$ do PIB, no conceito 'operacional' ${ }^{410}$.

A Lei $n^{\circ}$ 9.293/96, LDO para 1997, determinava que a mensagem que encaminhasse o projeto de lei orçamentária anual contivesse a indicação dos resultados primário e operacional implícitos no projeto de lei orçamentária anual para 1997, os estimados para 1996 e os observados em $1995^{411}$.

A Lei $n^{\circ}$ 9.811/99, LDO para 2000, continha dispositivo no sentido de que a elaboração do projeto, a aprovação e a execução da lei orçamentária de 2000 levasse em conta a obtenção de um superávit primário mínimo de, pelo menos, $\mathrm{R} \$ 30.500 .000 .000,00$ nos Orçamentos Fiscal, da Seguridade Social e das empresas estatais federais ${ }^{412}$.

Com a edição da Lei de Responsabilidade Fiscal, a produção das metas de resultado primário e nominal foi expressamente encampada pelo ordenamento jurídico, em consonância com os critérios de gestão fiscal responsável. Sobre isso, a LRF explicitou a necessidade do estabelecimento das regras fiscais, consubstanciadas nos resultados primário e nominal a serem obtidos pelo Governo.

\footnotetext{
${ }^{409}$ Art. $3^{\text {o }}, \S 1^{\text {o }}$, III, da Lei n ${ }^{\circ} 11.653 / 08$ (PPA para 2008-2011).

${ }^{410}$ Art. $42, \S 1^{\circ}$, II, da Lei $n^{\circ} 8.074 / 90$ (LDO para 1991).

${ }^{411}$ Art. $3^{\circ}, \S 2^{\circ}$, III, da Lei $n^{\circ} 9.293 / 96$ (LDO para 1997).

${ }^{412}$ Art. 18 da Lei $n^{\circ} 9.811 / 99$ (LDO para 2000).
} 
Claramente, o texto constitucional deixa assentado que a Lei de Diretrizes Orçamentárias compreenderá metas e prioridades da administração pública federal ${ }^{413}$. Desenvolvendo tal conceituação, com amparo no art. 165, § $9^{\circ}$, inciso I, da Carta Política de 1988, que atribui competência para que lei complementar disponha acerca da elaboração e organização das leis orçamentárias - PPA, LDO e LOA -, a Lei de Responsabilidade Fiscal introduziu, na estrutura das LDOs, o Anexo de Metas Fiscais, no qual são estabelecidas metas anuais relativas a receitas, despesas, resultados nominal e primário e montante da dívida pública ${ }^{414}$.

Destarte, em nosso ordenamento jurídico, incumbe à Lei de Diretrizes Orçamentárias a fixação das metas fiscais que orientarão a execução orçamentária do exercício financeiro subsequente. Tradicionalmente, o Capítulo I da LDO, que dispõe acerca das metas e prioridades da Administração Pública Federal, é inaugurado com o artigo que fixa a meta da política fiscal do exercício vindouro.

A responsabilidade na gestão fiscal foi realçada pela LRF que destaca a necessidade de ação planejada e transparente, assegurando o equilíbrio das contas públicas mediante o cumprimento de metas de resultados entre receitas e despesas ${ }^{415}$. Ademais, a existência de metas anuais fixadas no Anexo de Metas Fiscais da LDO atende a uma determinação legal expressamente consignada na $\mathrm{LRF}^{416}$.

A Lei $n^{\circ} 11.768 / 08$, LDO para 2009, estabelece, em seu art. $2^{\circ}$, que a elaboração, a aprovação e a execução da Lei Orçamentária de 2009 devem ser compatíveis com a obtenção da meta de superávit primário para o setor público consolidado, equivalente a $3,80 \%$ do $\mathrm{PIB}^{417}$.

Nesse sentido, a elaboração e execução da LOA encontram-se submetidas à observância das metas fiscais estabelecidas na LDO. Não por outro motivo, eventuais alterações na programação orçamentária constante da LOA, por meio de abertura de créditos suplementares, somente são admitidas caso sejam compatíveis com a obtenção da meta de resultado primário estabelecida no Anexo de Metas Fiscais da LDO $^{418}$.

As metas fiscais, portanto, constituem-se em um parâmetro de observância obrigatória no manejo e alteração da composição orçamentária inicialmente fixada pela LOA às diversas unidades orçamentárias. As metas fiscais estabelecem uma relação de

\footnotetext{
${ }^{413}$ Art. $165, \S 2^{\circ}$, da CF/88.

${ }^{414}$ Art. $4^{\circ}, \S 1^{\circ}$, da LRF.

415 Art. $1^{\circ}, \S 1^{\mathrm{o}}$, da LRF.

${ }^{416}$ Art. $4^{\mathrm{o}}, \S 1^{\mathrm{o}}$, da LRF.

${ }^{417}$ Art. $2^{\circ}$ da Lei ${ }^{\circ} 11.768 / 08$ (LDO para 2009).

${ }^{418}$ Art. $4^{\circ}$, caput, da Lei $\mathrm{n}^{\circ} 11.897 / 09$ (LOA para 2009).
} 
proporção que deve ser mantida entre receitas e despesas ${ }^{419}$, para uma fiel execução da política econômica estabelecida pelo Governo.

Desse modo, a primeira constatação que se infere de tais dispositivos é que as metas fiscais se constituem em uma obrigação estabelecida pelas leis orçamentárias e, por isso, possuem um nítido teor mandatório. As LOAs quando estabelecem metas fiscais não estão a atribuir uma mera faculdade ao gestor; ao contrário, obrigam e vinculam a Administração ao seu atingimento.

Exatamente porque se encontram revestidas de um caráter de cogência, as metas fiscais das leis orçamentárias são passíveis de fiscalização pelos órgãos de controle, como se extrai da leitura do art. 59 da LRF:

Art. 59. O Poder Legislativo, diretamente ou com o auxílio dos Tribunais de Contas, e o sistema de controle interno de cada Poder e do Ministério Público, fiscalizarão o cumprimento das normas desta Lei Complementar, com ênfase no que se refere a: I - atingimento das metas estabelecidas na lei de diretrizes orçamentárias; (...)

As metas fiscais, estabelecidas inicialmente na LDO, são concretizadas por intermédioda elaboração e execução da Lei de Orçamento. O projeto da LOA deve ser elaborado de forma a estabelecer uma determinada proporção entre receitas e despesas primárias que assegure o alcance das metas fiscais. Todavia, não basta a mera elaboração em consonância às referidas metas. Durante todo o processo de execução orçamentária, há que se observar, inclusive quando da abertura de créditos adicionais, se as alterações efetuadas não prejudicam o alcance das metas fiscais estabelecidas.

Sendo assim, as metas fiscais estabelecidas e fixadas na Lei de Orçamento são obrigatórias, no sentido de que não somente condicionam toda a execução orçamentária, como também revelam um objetivo a ser alcançado pela LOA.

Nesse tocante, não há que se falar em autorização, visto que o responsável pela gestão fiscal, no caso o mandatário à frente da condução do Governo, em qualquer de suas esferas, deve envidar os esforços necessários ao alcance das metas estabelecidas, de modo que a responsabilidade na gestão fiscal permita, de forma sustentável, a efetiva concretização das condições necessárias à implementação dos comandos constitucionais relativos à dignidade da pessoa humana.

\footnotetext{
${ }^{419}$ Nas palavras de Jesse Burkhead, "No exame dos agregados, a diretriz estabelecida é a política fiscal - a determinação do nível das operações governamentais como um todo e a inter-relação entre a receita e a despesa. Um dos resultados importantes é a autorização de um déficit ou superávit no orçamento global". BURKHEAD, Jesse, op. cit., p. 407.
} 


\title{
4.4 Conteúdo Jurídico do Orçamento das Receitas
}

Indiscutivelmente, a separação entre os princípios da anualidade orçamentária e da legalidade tributária trouxe grande repercussão à discussão da Lei de Orçamento, condicionando muitos dos debates posteriores, no que se refere às receitas. Enquanto essa Lei revestia a condição de eficácia de leis tributárias, ostentava inegável importância.

Contudo, a bifurcação dos referidos princípios, em grande parte dos ordenamentos jurídicos modernos, acarretou significativa perda de força jurídica da Lei de Orçamento, relativamente aos tributos. Nesse sentido, tem-se a lição de Sainz de Bujanda:

\begin{abstract}
Mientras el principio de legalidad tributaria estuvo inseparablemente unido al principio de anualidad del Presupuesto y, en consecuencia, no podían exigirse tributos que no hubieran sido establecidos mediante ley aprobada por los representantes de quienes habían de pagarlos (Parlamento, Cortes) o cuya recaudación o exacción no estuviese prevista y autorizada por la ley anual del Presupuesto, es claro que la definición jurídica del Presupuesto como acto de autorización, tanto de ingresos como de gastos públicos, era plenamente válida.

Pero a partir del momento en que el crecimiento de las necesidades financieras impuso la organización de los tributos en un sistema permanente de ingresos y determinó, en consecuencia, la bifurcación del principio de legalidad financiera y la desconexión del sistema tributario de la aprobación anual de los Presupuestos del Estado, la Ley Presupuestaria vino a perder gran parte de su significación jurídica respecto a los tributos, en cuanto que la Administración está obligada a exigir su pago de los contribuyentes, no en virtud de la autorización anual de la Ley de Presupuestos, sino en virtud de las leyes propias de cada tributo que definen su aplicación ${ }^{420}$.
\end{abstract}

Foi exatamente a questão da autorização das receitas pela Lei de Orçamento, enquanto tônica dominante da corrente doutrinária francesa, filiada à Duguit e Jèze - e, justamente, motivo de divergência entre os juristas franceses -, o que permitiu que aquela corrente apresentasse singularidades, muito embora se inclua no que se convencionou chamar de Abordagem Clássica da Lei de Orçamento, a exemplo da introdução da figura do ato-condição nos debates sobre o Orçamento.

Inexistente a regra da anualidade tributária no ordenamento jurídico, haveria um certo consenso entre os juristas no sentido de que o Orçamento adquiriria o caráter de mera previsão dos recursos a serem auferidos pelo Estado no exercício de suas atividades de arrecadação dos tributos e demais receitas instituídas pela legislação tributária pertinente. Sobre isso, Laband destacava que:

420 SAINZ DE BUJANDA, Fernando. Lecciones de Derecho Financiero. $7^{\mathrm{a}}$ ed. Madrid: Universidad Complutense, 1989, p. 431/432. 
Los impuestos vigentes rigen en virtud de leyes especiales que mantienen su vigencia en tanto no queden derogadas o modificadas por nuevas leyes. El Presupuesto no constituye el fundamento jurídico de la exacción impositiva, ocurriendo más bien que son las leyes tributarias las que constituyen el fundamento legal por el que se incluyen los ingresos tributarios en el Presupuesto ${ }^{421}$.

Adicionalmente, Sainz de Bujanda também salientava, de forma semelhante, que a Lei de Orçamento apresentaria a significação de mera estimativa, com relação às receitas: "El Presupuesto, en cuanto a los ingresos, adquiere el valor de una simple previsión o cálculo de lo que el Estado espera recaudar mediante la aplicación de las leyes que regulan su sistema de recursos" $" 422$.

Entre nós, a análise feita por José Afonso da Silva aponta na mesma direção:

o chamado orçamento das receitas não passa efetivamente de operação contábil e financeira, no sentido de saber qual a estimativa das receitas disponíveis para a execução dos programas orçamentários. Essa parte não inova nada, não é lei, pois não mais se exige prévia autorização orçamentária para arrecadação das receitas tributárias e outras. Bastam as leis que as instituíram e a ocorrência dos respectivos fatos geradores e do lançamento, para que possam ser cobradas ${ }^{423}$.

Ao contrário, muito diversa seria a significação jurídica da lei orçamentária nos ordenamentos em que se encontra em vigor o princípio da anualidade tributária, por meio do qual somente os tributos previstos e consignados na lei orçamentária adquiririam a indispensável vigência para que sua cobrança se tornasse possível, a exemplo do que ainda ocorre no ordenamento jurídico francês ${ }^{424}$.

No ordenamento jurídico brasileiro, a LOA não tem o condão de condicionar a arrecadação de receitas previstas em leis próprias e específicas. Em outras palavras, a legislação permanente referente aos tributos não se encontra na dependência de qualquer consignação na lei orçamentária.

A jurisprudência pacífica do Supremo Tribunal Federal, nesse aspecto, não deixa margem a dúvidas:

O entendimento do Supremo Tribunal Federal, manifestado na vigência da Constituição de 1946, ainda válido hoje, é no sentido de ser legítima a cobrança de aumento de

\footnotetext{
${ }^{421}$ LABAND, Paul. Derecho Presupuestario. Trad. Jose Zamit. Madrid: Instituto de Estudios Fiscales, 1979, p. 39.

${ }^{422}$ SAINZ DE BUJANDA, Fernando. Lecciones de Derecho Financiero. $7^{\mathrm{a}}$ ed. Madrid: Universidad Complutense, 1989, p. 432.

${ }^{423}$ SILVA, José Afonso da. Orçamento-Programa no Brasil. São Paulo: Revista dos Tribunais, 1973, p. 271.

${ }^{424}$ No modelo francês, tradicionalmente e até os dias atuais, a lei orçamentária incorpora a força de autorizar, anualmente, o recebimento dos impostos e demais receitas públicas.
} 
tributo determinado por lei posterior ao orçamento, quando este já incluía o tributo, em termos genéricos, na previsão da receita ${ }^{425}$.

No mesmo sentido, encontra-se a Súmula no 66 do Supremo Tribunal Federal, que dispõe: "é legítima a cobrança do tributo que houver sido aumentado após o orçamento, mas antes do início do respectivo exercício financeiro".

A doutrina majoritária acompanha tal entendimento. Ricardo Lobo Torres, por exemplo, defende que a anualidade tributária teria desaparecido a partir da Emenda $\mathrm{n}^{\circ}$ 01/1969, à Carta de 1967, sendo substituída pelo princípio da anterioridade, que impede a criação ou o aumento de tributos no ano da execução orçamentária ${ }^{426}$. Regis Fernandes de Oliveira advoga também para possibilidade de cobrança do tributo já instituído e ressalta que "o advento da Constituição de 1988 não alterou a solução que já havia sido dada"427.

Há que se registrar o entendimento contrário de Ives Gandra da Silva Martins, para quem persiste a manutenção da anualidade tributária, e, dessa forma, somente os impostos previamente constantes da lei orçamentária poderiam ser exigidos.

Em conformidade com o entendimento majoritário, faria sentido considerar as receitas previstas e detalhadas na LOA como meramente estimativas e, portanto, desprovidas de qualquer teor jurídico. Contudo, cabe uma investigação mais detalhada para se saber se efetivamente os dispositivos da lei orçamentária relativos à previsão de receitas ostentam, tão-somente, o caráter de estimativa.

É fato que, entre nós, a previsão dos recursos financeiros nas diversas rubricas relativas às receitas não é condição de validade e de aplicação das leis tributárias. No entanto, o mesmo não se pode afirmar a respeito da meta anual de $\operatorname{arrecadação~}^{428}$, posteriormente desdobrada em metas bimestrais $^{429}$, visto que as leis tributárias não estabelecem metas de arrecadação ou objetivos a serem alcançados no exercício das atividades de cobrança e fiscalização tributárias.

A existência de metas bimestrais de arrecadação parece introduzir um elemento novo, que não se encontra na legislação tributária permanente. Efetivamente, se há metas a serem alcançadas, existe um nítido viés de obrigação ou esforço a ser despendido, pelos órgãos arrecadadores, no intuito do alcance dos objetivos anteriormente fixados.

${ }^{425}$ SUPREMO TRIBUNAL FEDERAL. Recurso em Mandado de Segurança ${ }^{\circ}$ 8.361, Rel. Min. Victor Nunes Leal.

${ }^{426}$ TORRES, Ricardo Lobo, op. cit., p.76/77.

${ }^{427}$ OLIVEIRA, Regis Fernandes de, op. cit., p.347.

${ }^{428} \mathrm{O}$ art. $1^{\circ}$ da Lei ${ }^{\circ} 11.897 / 09$ (LOA para 2009) estima o valor total da receita da União para o exercício financeiro de 2009.

${ }^{429}$ Art. 13 da LRF. 
Logo, as metas de arrecadação, que representam uma divisão da estimativa total de receitas fixada na Lei de Orçamento, possuem um caráter de determinação exarado à Administração Pública. As referidas metas são estabelecidas anualmente, considerando-se expectativas de crescimento do PIB e do nível da atividade econômica, bem como de maior eficiência e eficácia na atividade desempenhada pelos órgãos incumbidos da arrecadação tributária.

Ademais, as projeções de receita devem ser tratadas de forma técnica e isenta e é exatamente por isso que eventuais reestimativas feitas pelo Poder Legislativo somente poderão ocorrer caso se comprove erro ou omissão de ordem técnica ou legal ${ }^{430}$.

Nesse sentido, a cada ano, há que se proceder à fixação das metas de arrecadação, as quais se incorporam ao ordenamento jurídico vigente, ao lado da legislação tributária que institui as diversas receitas, inovando-o, nesse aspecto.

Por outro lado, as metas de arrecadação das receitas acabam por se encontrar diretamente relacionadas com as metas fiscais, uma vez aquelas visam, em parte, possibilitar o alcance dos objetivos fiscais e, em parte, financiar o alcance dos objetivos previstos nos diversos programas constantes da Lei de Orçamento. Dessa forma, as metas de arrecadação representam um dos elementos de suporte de alcance das metas fiscais, que são obrigatórias, como visto.

Efetivamente, não parece haver muito sentido em se desdobrar as receitas previstas em metas bimestrais de arrecadação, se os valores bimestrais fossem, tão-somente, estimativos. Mais do que isso, as falhas no alcance das metas de arrecadação implicam em consequências jurídicas bem definidas, no ordenamento brasileiro.

Não por outro motivo, se verificado, ao final de um bimestre, que a realização da receita poderá não comportar o cumprimento das metas de resultado primário ou nominal, os Poderes e o Ministério Público deverão promover, por ato próprio e nos montantes necessários, limitação de empenho e movimentação financeira, segundo os critérios fixados pela $\mathrm{LDO}^{431}$.

Em outras palavras, caso não se atinja o montante de arrecadação necessário para possibilitar o alcance das metas fiscais e, ao mesmo tempo, o financiamento dos programas orçamentários previsto, haverá a necessidade de se contingenciar as despesas por meio da limitação de empenho e movimentação financeira.

\footnotetext{
${ }^{430}$ Art. $12, \S 1^{\mathrm{o}}$, da LRF.

${ }^{431}$ Art. $9^{\circ}$, caput, da LRF.
} 
Dessa forma, não há como deixar de se reconhecer a obrigatoriedade do alcance das metas fixadas em termos de receita. Aqui não há que se falar em autorização de arrecadação, pois tal autorização encontra-se assentada na legislação permanente da receita. Portanto, as receitas consignadas na lei orçamentária possuem o condão de impregnar de obrigatoriedade a atuação dos órgãos envolvidos na arrecadação dos tributos existentes para o alcance das metas de arrecadação previstas.

Por outro aspecto, esse reconhecimento não implica qualquer restrição ao manejo de suas faculdades de condução da política econômica do Governo. Há impostos federais que são reconhecidamente utilizados, muitas vezes, com um cunho de extrafiscalidade, objetivando outros fins que não relacionados com a arrecadação aos cofres públicos.

Além disso, conjunturas adversas podem requerer a concessão de benefícios fiscais, a exemplo da recente diminuição das alíquotas relativas ao Imposto sobre Produtos Industrializados - IPI, com o objetivo explícito de fomentar a atividade econômica durante um período recessivo. Tais modificações implicam, sem qualquer dúvida, em alterações nas projeções de receitas e, consequentemente, nas metas de arrecadação inicialmente previstas. Podem requerer, inclusive, alterações na condução da política fiscal, que passa a ser utilizada com viés notadamente anticíclico, exigindo, consequentemente, alterações nas metas fiscais.

Contudo, tais fatos indicam problemas supervenientes que podem ocorrer após a elaboração da LOA, visto que, se as circunstâncias já fossem antecipadamente reconhecidas, suas consequências já teriam orientado a discussão, elaboração e aprovação da lei orçamentária, de modo a propiciar, da forma mais realista possível, a elaboração das metas e objetivos visados pelo Governo, em termos de política fiscal e de arrecadação das receitas federais.

Nesse sentido, o reconhecimento de modificações supervenientes ao cenário econômico não implica em desprestígio às metas fiscais e às metas de arrecadação. Ao contrário, enfatizam que a Lei de Orçamento orienta a condução do Governo sob circunstâncias que são ditadas pela realidade do mundo exterior, em face da qual, muitas vezes, são necessárias correções de rotas ou de condução governamental.

Dessa maneira, tais considerações enfatizam a complexidade do estudo da Lei de Orçamento, que se presta a ser um instrumento de política fiscal, bem como de um instrumento de condução dos programas governamentais e de execução das políticas públicas, visando à concretização dos valores e direitos constitucionais da sociedade. 
Todavia, se alterações são possíveis, perante a mutabilidade da realidade externa, elas não são legítimas em quaisquer circunstâncias, sob quaisquer pretextos. Não há, nesse caso, uma discricionariedade do administrador público para a livre escolha dos fins e objetivos. Nas palavras de Bandeira de Mello:

\begin{abstract}
a única razão lógica capaz de justificar a outorga de discrição reside em que não se considerou possível fixar, de antemão, qual seria o comportamento administrativo pretendido como imprescindível e reputado capaz de assegurar, em todos os casos, a única solução prestante para atender com perfeição ao interesse público que inspirou a norma. Daí a outorga da discricionariedade. (...)

É exatamente porque a norma legal só quer a solução ótima, perfeita, adequada às circunstâncias concretas, que, ante o caráter polifacético, multifário, dos fatos da vida, se vê compelida a outorgar ao administrador - que é quem se confronta com a realidade dos fatos segundo seu colorido próprio - certa margem de liberdade para que este, sopesando as circunstâncias, possa dar verdadeira satisfação à finalidade legal ${ }^{432}$.
\end{abstract}

Destarte, pode-se afirmar que, em princípio, as metas de arrecadação, as quais representam desdobramentos do montante total de receita previsto na Lei de Orçamento, possuem um cunho de obrigatoriedade, pois devem ser envidados os esforços necessários ao seu alcance.

Vejamos o tratamento conferido a tais questões, no ordenamento brasileiro. $\mathrm{O}$ art.

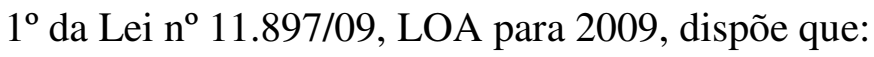

Art. $1^{\circ}$. Esta Lei estima a receita da União para o exercício financeiro de 2009 no montante de R \$ 1.660.729.655.083,00 (um trilhão, seiscentos e sessenta bilhões, setecentos e vinte e nove milhões, seiscentos e cinqüenta e cinco mil e oitenta e três reais) e fixa a despesa em igual valor, compreendendo, nos termos do art. $165, \S 5^{\circ}$, da Constituição, e dos arts. $6^{\circ}, 7^{\circ}$ e 55 da Lei $n^{\circ} 11.768$, de 14 de agosto de 2008 , Lei de Diretrizes Orçamentárias para 2009.

Nos termos utilizados pela própria Lei Orçamentária, a receita estimada para o exercício financeiro é aquela mencionada acima, que, a seu turno, financiará as despesas a serem executadas pelos órgãos e entidades da Administração Pública.

Por sua vez, o Decreto $n^{\circ}$ 6.752/09 dispôs sobre a programação orçamentária e financeira, estabelecendo o cronograma mensal de desembolso do Poder Executivo para o exercício de 2009.

Do Anexo VII desse Decreto consta a previsão de arrecadação das receitas federais para o exercício de 2009. As rubricas das receitas são devidamente discriminadas e desdobradas nas metas bimestrais, as quais, somadas, perfazem o volume total de receitas

${ }^{432}$ BANDEIRA DE MELLO, Celso Antônio. Discricionariedade e Controle Jurisdicional. $2^{\mathrm{a}}$ ed., $7^{\mathrm{a}}$ tiragem. São Paulo: Malheiros, 2006, p. 33/35. 
previsto para o exercício financeiro ${ }^{433}$. A título exemplificativo, apresenta-se, na tabela abaixo, o desdobramento bimestral da projeção da receita prevista para o Imposto sobre Operações Financeiras - IOF:

\begin{tabular}{|c|c|c|c|c|c|c|c|}
\hline \multirow{2}{*}{ Receita } & \multicolumn{6}{|c|}{ Prevista } & \multirow{2}{*}{ Total } \\
\cline { 2 - 7 } & $1^{o}$ bim. & $2^{\circ}$ bim. & $3^{o}$ bim. & $4^{\circ}$ bim. & $5^{\circ}$ bim. & $6^{\circ}$ bim. & \\
\hline IOF & 3.152 & 3.106 & 3.807 & 3.776 & 3.921 & 4.115 & 21.876 \\
\hline
\end{tabular}

Fonte: Anexo VII - Arrecadação/Previsão das Receitas Federais - 2009 (em R\$ milhões) - Decreto nº 6.752/09.

Nos Anexos da Lei Orçamentária são apresentados, ainda, uma série de tabelas e quadros que discriminam as receitas previstas, incluindo-se o detalhamento da receita dos Orçamentos Fiscal e da Seguridade Social por natureza, fontes de recursos e esfera; quadro demonstrativo da Evolução da Receita do Tesouro Nacional segundo as Categorias Econômicas; bem como tabela em que são discriminados os recursos próprios e vinculados de todas as fontes, por órgão e unidade orçamentária.

Os dispositivos da LOA relativos às receitas discriminam o montante total da receita prevista para todos os Orçamentos, quais sejam, Fiscal, da Seguridade Social e de Investimentos $^{434}$, bem como a discriminação da receita estimada para cada um dos Orçamentos componentes do Orçamento Geral da União ${ }^{435}$.

Não por outro motivo, a lei orçamentária dispôs, explicitamente, que os anexos relativos à receita estimada nos Orçamentos Fiscal e da Seguridade Social, por categoria econômica e fonte, à discriminação das fontes de investimento do Orçamento de Investimento à das receitas dos Orçamentos Fiscal e da Seguridade Social, entre outros, integram a LOA ${ }^{436}$.

Tais detalhamentos seriam totalmente inócuos e destituídos de sentido caso representassem, tão-somente, mero exercício de futurologia. Os desdobramentos servem de orientação para os órgãos e unidades orçamentários diretamente envolvidos no processo orçamentário, na medida em que permitem a visualização das receitas a serem auferidas e posteriormente utilizadas como fonte para a utilização das dotações constantes da lei.

\footnotetext{
${ }^{433}$ Anexo VII do Decreto $n^{\circ}$ 6.752/09 (Decreto de programação orçamentária e financeira). Disponível em [https://www.portalsof.planejamento.gov.br/bib/legislacao/decretos/Anexo_Decreto_de_280109.pdf]. Acesso em 08.10.09.

${ }^{434}$ Art. $1^{\circ}$ da Lei $n^{\circ} 11.897 / 09$ (LOA para 2009).

${ }^{435}$ Arts. $2^{\circ}$, incisos I e II, e $6^{\circ}$ da Lei $n^{\circ} 11.897 / 09$ (LOA para 2009).

${ }^{436}$ Art. 11, incisos I, III e IX, da Lei no 11.897/09 (LOA para 2009).
} 
As metas de arrecadação, que são o suporte do alcance das metas de resultado primário são introduzidas no ordenamento jurídico por meio das leis orçamentárias e possuem um caráter de determinação exarado à Administração Pública. Essa constatação não impede que se reconheça, por outro lado, que nosso ordenamento não confere, relativamente, às receitas, o mesmo tratamento conferido por ordenamentos como o francês, no qual a Lei de Orçamento renova a permissão para a cobranças das receitas públicas. Contudo, no caso brasileiro também não se pode defender um caráter de mera estimativa para o Orçamento das Receitas.

\subsection{Conteúdo Jurídico do Orçamento das Despesas}

\subsubsection{Fundamento jurídico das despesas}

De acordo com a visão orçamentária clássica, o orçamento não se constituiria na fonte jurídica das despesas, que encontrariam em outras leis seu fundamento legal, necessário e suficiente. Em outros termos:

la ley presupuestaria no constituye al 'fundamento legal' ni de la realización de gastos ni de la recaudación de ingresos, siendo solamente la constatación del acuerdo entre el Gobierno y el Parlamento sobre la idoneidad de la estimación previa y sobre la necesidad y conveniencia de las sumas en ella indicadas. El fundamento legal para la realización de los gastos ya existe, sin necesidad de Presupuesto, en la inmensa mayoría de los mismos ${ }^{437}$.

Embora Laband não coloque ênfase no orçamento enquanto fonte jurídica das despesas, ele não deixa de reconhecer que existem gastos que possuem, como fonte única e exclusiva de legitimação, a Lei de Orçamento. Porém, uma vez que a lei orçamentária fundamentaria apenas uma pequena parcela das despesas, em contraposição a um volume muito maior que encontraria sua fonte geradora em outras leis, a Lei de Orçamento representaria uma fonte insignificante de despesas. Em suas palavras:

Es cierto que hay cada año gastos para los que el Gobierno no tiene otra legitimación que la de la ley presupuestaria y para cuya realización, por tanto, carecería de capacidad jurídico-pública sin el Presupuesto; pero ésta es una pequeña parte, tendente a desaparecer, de los gastos frente a la masa principal de los mismos, que están basados

${ }^{437}$ LABAND, Paul. Derecho Presupuestario. Trad. Jose Zamit. Madrid: Instituto de Estudios Fiscales, 1979, p. 126. 
en leyes especiales y en su tradicional institución, ya reconocida, por el Estado. La ley presupuestaria no es, para estos gastos, 'el fundamento legal' indispensable puesto que dicho fundamento está ya ahí sin Presupuesto; y el Gobierno no necesita forzosamente de una autorización legal por parte de la ley presupuestaria, para la realización de tales gastos puesto que ya posee dicha autorización en virtud de otras leyes. En la Ley Constitucional tampoco se dice en ningún precepto que el Gobierno precisa ser autorizado por la ley presupuestaria para la realización de gastos o que necesita una autorización de esta naturaleza. Lo único que prevé el art. 99 es la confección anual de una estimación que comprenda todos los ingresos y gastos del Estado y la fijación de la misma por medio de una ley ${ }^{438}$.

De antemão, convém deixar registrado que, ao contrário do que Laband depreende dos ditames constitucionais da Prússia do século XIX, no sistema constitucional brasileiro existe um princípio constitucional expresso a nortear o debate, previsto no art. 167, II, da Carta da República e segundo o qual se veda a realização de despesas ou a assunção de obrigações diretas que excedam os créditos orçamentários ou adicionais. Em outras palavras, nosso ordenamento veda a realização de despesas sem previsão orçamentária.

Dessa forma, há duas diferentes questões que precisam ser resolvidas, para uma adequada análise do tema. Em primeiro lugar, cumpre que se investigue se a Lei de Orçamento pode se constituir no fundamento primeiro de despesas públicas. Em segundo, cabe esclarecer se outras leis, que não a do Orçamento, podem se constituir no fundamento primário de despesas e, em caso positivo, se tal fato implica, de algum modo, em diminuição ou modificação da eficácia jurídica da lei orçamentária.

As despesas podem ser classificadas em obrigatórias ou discricionárias, em função da existência de dispositivos constitucionais ou de leis anteriores que as determinem, ou não. Ou seja, a referida distinção aponta para a existência de despesas que se originam, primeiramente, de leis ou da própria Constituição, assim como para a existência de despesas que não possuem o citado fundamento legal.

Classificação similar é apresentada por Aliomar Baleeiro, que distinguia as despesas em fixas ou variáveis. As despesas fixas seriam representadas pelos gastos decorrentes de determinação constitucional ou legal, enquanto que as despesas variáveis seriam destituídas do referido amparo em lei. Nas palavras desse autor:

Quanto às despesas, há que distinguir se são fixas ou variáveis. As primeiras só poderão ser alteradas por efeito de lei anterior, evidentemente porque resultam da execução da Constituição ou de leis, como os subsídios do Presidente da República e congressistas, vencimentos dos funcionários, obrigações da Dívida Pública, etc. (...) As despesas

${ }^{438}$ LABAND, Paul, op. cit., p. 91/92. 
variáveis como simples autorizações, destituídas de amparo em lei, facultam a ação do Executivo até limite previsto. São créditos limitativos e não imperativos ${ }^{439}$.

As despesas obrigatórias, portanto, poderiam ter como fundamento a própria Constituição ou outra lei. As despesas constitucionais obrigatórias constituem-se de gastos determinados por regras constitucionais que prevêem a necessidade de aplicação de percentuais mínimos de receitas em alguns setores, a exemplo do que ocorre com o mínimo da educação e da saúde.

Nesse sentido, quando o texto constitucional dispõe que a União aplicará, anualmente, nunca menos de $18 \%$ da receita resultante de impostos, compreendida a proveniente de transferências, na manutenção e desenvolvimento do ensino ${ }^{440}$, nada mais fez do que determinar a realização de uma despesa.

A Constituição de 1988 também determina que as ações e serviços públicos de saúde deverão receber, anualmente, recursos mínimos derivados da aplicação de percentuais calculados nos termos de lei complementar ${ }^{441}$. Em razão da falta de edição da mencionada lei complementar, tem sido aplicado o art. 77 do Ato das Disposições Constitucionais Transitórias - ADCT, que remete ao montante empenhado em ações e serviços públicos de saúde do ano anterior, corrigido pela variação nominal do $\mathrm{PIB}^{442}$.

São reconhecidas, ainda, como despesas constitucionais obrigatórias as dotações para pessoal e seus encargos, para o serviço da dívida e para as transferências tributárias constitucionais para Estados, Municípios e Distrito Federal, visto que, nesses casos, há explícita vedação para anulação das referidas dotações, pelo Congresso, quando da discussão e votação da $\operatorname{LOA}^{443}$.

A legislação infraconstitucional também pode se constituir em fonte de criação de despesas, notadamente quando outorga a certos grupos ou segmentos sociais o direito a determinadas prestações ou benefícios, desde que implementadas as condições estabelecidas na lei.

A Lei $n^{\circ} 6.179 / 74$, por exemplo, instituiu amparo previdenciário para maiores de 70 anos de idade e para inválidos, desde que fossem preenchidas determinadas condições. Assim, aquele estatuto legal, ao assegurar a todos aqueles que preenchessem os requisitos

${ }^{439}$ BALEEIRO, Aliomar. Uma Introdução à Ciência das Finanças. 12a ed. Rio de Janeiro: Forense, 1978, p. 426.

${ }^{440}$ Art. 212, caput, CF/88.

${ }^{441}$ Art. $198, \S 2^{\circ}, \mathrm{I}, \mathrm{CF} / 88$.

${ }^{442}$ Art. 77, I, 'a' e 'b', do ADCT - CF/88.

${ }^{443}$ Art. $166, \S 3^{\circ}$, II, 'a', 'b' e 'c', CF/88. 
necessários o direito à percepção do benefício, nada mais fez do que se constituir no fundamento legal primeiro das despesas de que trata. Preenchidas as condições fixadas na legislação, todo aquele que se encontre no espectro de abrangência da lei fará jus à percepção da prestação instituída, devendo os recursos necessários ao cumprimento da obrigação se encontrarem previstos na Lei Orçamentária ${ }^{444}$.

Tome-se outro exemplo. A Lei $\mathrm{n}^{\mathrm{o}}$ 11.520/07 dispôs sobre a concessão de pensão especial às pessoas atingidas pela hanseníase que foram submetidas a isolamento e internação compulsórios. Nos termos dessa lei, todos que preenchessem os requisitos previstos, poderiam requerer a concessão do benefício. Dessa forma, este estatuto legal criou a obrigatoriedade de pagamento das despesas relacionadas ao referido benefício.

Existem, ainda, diversas leis que dispõem acerca das estruturas remuneratórias de servidores públicos. A Lei $\mathrm{n}^{\circ}$ 11.890/08, por exemplo, dispôs sobre a reestruturação da composição remuneratória de diversas carreiras do ciclo de gestão do Governo Federal. Esse diploma legal gera, inevitavelmente, repercussões nas dotações relativas ao pagamento dos subsídios do funcionalismo público. Por isso, as estimativas a serem realizadas e posteriormente incluídas na LOA deverão observar as referidas alterações legais.

Destarte, diversas leis e a própria Constituição Federal podem se constituir no fundamento primário de certas despesas e, além disso, determinar a realização dos gastos necessários ao cumprimento das obrigações a que dão origem. A Lei de Orçamento, nesses casos, não se constitui na fonte jurídica primeira dessas despesas, não obstante haja a necessidade de se encontrarem previstas na peça orçamentária as dotações necessárias à viabilização do respectivo pagamento ${ }^{445}$.

De toda forma, há que se proceder, nesse momento, a uma relevante distinção: a diferença entre obrigação e despesa. As despesas decorrem de obrigações anteriormente contraídas, que, por sua vez, possuem como fundamento a lei ou o contrato.

No direito romano, quatro eram consideradas as fontes das obrigações: o contrato, o delito, o quase contrato e o quase delito ${ }^{446}$. Posteriormente, reconheceu-se a existência de obrigações surgidas diretamente do ordenamento jurídico positivo e, em consequência,

\footnotetext{
${ }^{444}$ Art. 167, II, CF/88.

${ }^{445}$ Art. 167, II, CF/88: "São vedados: II - a realização de despesas ou a assunção de obrigações diretas que excedam os créditos orçamentários ou adicionais".

446 AZEVEDO, Álvaro Villaça. Teoria Geral das Obrigações e Responsabilidade Civil. $11^{\text {a }}$ ed. São Paulo: Atlas, 2008, p. 23/24.
} 
foi necessária a inclusão da lei como fonte das obrigações ${ }^{447}$. Dessa forma, fortaleceu-se a idéia da lei como fonte primeira das obrigações.

Efetivamente, a lei pode gerar para o Estado uma determinada obrigação, diante da qual o postulante requisitará a concessão do benefício instituído e o Estado, procurando adimplir com sua obrigação, determinará o pagamento ao beneficiário. Contudo, há que se notar que, eventualmente, poderá não ocorrer a despesa. Por exemplo, caso alguém faça jus a um benefício, mas não o solicite, continuará a existir uma obrigação para o Estado e um direito conferido ao indivíduo. Todavia, a despesa não foi gerada diretamente da lei; o que a lei gera é uma determinada obrigação.

Portanto, o que se quer destacar é que a lei não gera, por si mesma, uma despesa. $\mathrm{O}$ que a lei gera é uma obrigação e, em função de uma solicitação respaldada pela lei, alguém fará jus a um benefício, acarretando, consequentemente, uma despesa para o Estado. Como destaca Paulo Nader:

\begin{abstract}
A fonte geral das obrigações é constituída pelos fatos jurídicos lato sensu. Não há crédito e débito sem que lhes anteceda algum acontecimento do mundo fático regulado por norma jurídica. São fontes específicas das obrigações: os contratos, as declarações unilaterais de vontade, os atos ilícitos civis. A lei constitui pressuposto básico das obrigações e raramente se apresenta como elemento-fonte. As obrigações nascem de fatos jurídicos. A norma legal apenas dispõe a respeito, fixando os princípios norteadores dos fatos jurídicos e regulamentando-os sem, contudo, esgotar a matéria. A lei atua diretamente como elemento-fonte nos domínios do Direito Público ${ }^{448}$.
\end{abstract}

Feitas essas considerações, há que se discutir o fundamento legal das despesas discricionárias, uma vez que existem despesas que não possuem qualquer outro fundamento para sua realização, visto que não se encontram determinadas, a priori, em nenhum estatuto legal ou, de forma explícita, na Constituição. Esse é o caso das despesas discricionárias.

O fundamento legal para a realização das despesas se encontra, justamente, na LOA, a qual se constitui no seu fundamento legal primário. Sem que estejam previstas nessa Lei, tais despesas não poderão ser realizadas, haja vista que lhes faltará o fundamento legal legitimador de sua realização.

Efetivamente, a lei orçamentária, consoante expressa determinação constitucional, fixará a despesa ${ }^{449}$. Portanto, não há como se deixar de reconhecer que a Lei de Orçamento

\footnotetext{
${ }^{447}$ Ibid., p. 24.

${ }^{448}$ NADER, Paulo. Curso de Direito Civil. Vol. 3. Contratos. Rio de Janeiro: Forense, 2009, p. 5.

${ }^{449}$ Art. $165, \S 8^{\circ}, \mathrm{CF} / 88$.
} 
se constitui, explicitamente, em fundamento legal de realização da despesa, contando, nesse caso, com amparo direto e explícito da Carta Constitucional.

Desse modo, se é fato que outras leis, que não a orçamentária, podem instituir a obrigatoriedade de execução de certas despesas, isso não pode significar que a lei orçamentária não possa, por si mesma, e sem qualquer outro respaldo, ser o fundamento legal da realização de despesas.

O que ocorre é que a Lei de Orçamento não se constitui no fundamento único $e$ exclusivo das despesas, que podem, e efetivamente são, determinadas diretamente pela Constituição e/ou por outras leis infraconstitucionais. Entretanto, disso não se infere que a Lei Orçamentária não seja o fundamento legal exclusivo das despesas discricionárias.

Contribui, para a proliferação de entendimentos equivocados quanto ao tema em questão, o fato de haver um elevado grau de rigidez orçamentária em nosso sistema. A essa rigidez se manifesta pelo fato de que a maior parcela dos recursos orçamentários se encontra vinculada a determinadas despesas, determinadas diretamente pela própria Constituição ou criadas por leis infraconstitucionais que asseguram a certos beneficiários direitos sociais.

Há rigidez orçamentária sob duas óticas distintas, mas complementares: pelo lado da receita e pelo da despesa. A rigidez orçamentária, sob a ótica das receitas, refere-se ao fato de que grande parte dos recursos auferidos não pode ser utilizada para financiar despesas diferentes daquelas para as quais foram criados. A seu turno, a rigidez, pela via das despesas, refere-se ao crescimento contínuo das despesas de execução constitucional elou legal obrigatórias ${ }^{450}$. Nas palavras de Fernando Rezende e Armando Cunha, a rigidez orçamentária seria:

(...) o resultado do acúmulo de pressões sobre o orçamento que se originam:

- de compromissos financeiros acumulados no passado;

- de direitos assegurados em lei a grupos sociais mais bem organizados;

- das regras que estabelecem os mecanismos de transferência de recursos físcais na Federação;

- de garantias instituídas com respeito ao financiamento de determinados programas governamentais (vinculações de receita) ${ }^{451}$.

${ }^{450}$ SECRETARIA DE ORÇAMENTO FEDERAL. Vinculações de Receitas dos Orçamentos Fiscal e da Seguridade Social e o Poder Discricionário de Alocação dos Recursos do Governo Federal, p. 04. Disponível em [https://www.portalsof.planejamento.gov.br/bib/Estudos/Vinculacoes_Consolidado.pdf]. Acesso em 21.10.09.

451 REZENDE, Fernando; CUNHA, Armando. Disciplina Fiscal e Qualidade do Gasto Público Fundamentos da Reforma Orçamentária. Rio de Janeiro: FGV, 2005, p. 10. 
Aqui nos interessa, particularmente, o fenômeno dessa rigidez pela via das despesas, em razão do crescimento de despesas constitucionais e/ou legais obrigatórias ${ }^{452}$.

Por esse motivo, Laband destacou que a lei orçamentária seria o fundamento legal de apenas uma pequena parcela dos gastos, parcela essa que tenderia a desaparecer em face do grande volume de gastos baseados em outras leis: “ésta es una pequeña parte, tendente a desaparecer, de los gastos frente a la masa principal de los mismos, que están basados en leyes especiales y en su tradicional institución" ${ }^{453}$.

O fenômeno da rigidez orçamentária, portanto, contribui para a diminuição da importância do Orçamento, considerado como principal arena decisória para a fixação da despesa. Contudo, o fato de haver um elevado grau de rigidez orçamentária pelo lado das despesas, não impede que o orçamento seja, por excelência, o campo no qual podem ser definidas e fixadas as despesas a serem realizadas. Tal problemática é analisada por Fernando Rezende e Armando Cunha:

A redução do espaço orçamentário provoca reações. Setores mais organizados se unem na defesa de seus interesses e demandam novas vinculações, sem maiores considerações sobre a forma de financiá-las num quadro de escassez de recursos. Historicamente, a proteção de despesas nas áreas de saúde e educação adquiriu o status de conquista social assegurada pela Constituição Federal e, portanto, imune ao mecanismo de contingenciamento descrito. Outras áreas reivindicam tratamento semelhante, embora até o momento com menor sucesso.

A ampliação das vinculações engessa o orçamento e petrifica prioridades do passado para o futuro, além de, no limite, acabar com a margem passível de contingenciamento que vier a ser imprescindível para assegurar o equilíbrio fiscal num quadro de turbulências econômicas. De fato, a rigidez orçamentária, traduzida pelo alto grau de vinculações das receitas públicas e pela quantidade e valor das despesas obrigatórias, como já ressaltado em partes anteriores deste livro, tem tornado cada vez menor o espaço para a alocação de recursos e o planejamento efetivo das ações públicas ${ }^{454}$.

Assentada a premissa de que a Lei de Orçamento se constitui no fundamento legal primário das despesas discricionárias, enquanto que, com relação às despesas constitucionais e legais obrigatórias, a lei orçamentária não se constitui em sua fonte criadora, há que se verificar a diferença da extensão e contorno jurídico da lei orçamentária.

\footnotetext{
${ }^{452}$ Outros ordenamentos também apresentam os sintomas da rigidez orçamentária, embora em proporções menores do que aquelas existentes no caso brasileiro. No Brasil, $90,03 \%$ das despesas são relativas a gastos constitucionais e/ou legais obrigatórios, enquanto que menos de $10 \%$ do total referem-se a despesas discricionárias (conforme o Orçamento para 2010); nos Estados Unidos a proporção de gastos discricionários sobe para cerca de $35 \%$ do total das despesas federais.

${ }^{453}$ LABAND, Paul, op. cit., p. 91/92.

${ }^{454}$ REZENDE, Fernando; CUNHA, Armando, op. cit., p. 99.
} 
Quanto às despesas discricionárias, a Lei de Orçamento se constitui em sua fonte primeira, ostentando, nesse caso, a condição de fundamento jurídico da despesa. No entanto, a mesma condição não pode a Lei de Orçamento ostentar, diante de despesas que têm sua fonte em outras leis, que não o Orçamento, ou na Constituição.

Na segunda hipótese, ou seja, relativamente às despesas constitucionais e legais obrigatórias, o Orçamento representa a condição de realização das despesas. Isso ocorre uma vez que a Constituição veda a realização de despesas ou a assunção de obrigações diretas que excedam os créditos orçamentários ou adicionais ${ }^{455}$. Assim sendo, há necessidade de previsão dos recursos necessários, no Orçamento, para o pagamento das obrigações assumidas em virtude de outras leis.

No que se refere às despesas criadas por meio da Constituição ou de outras leis, o caráter da Lei de Orçamento se aproxima do conteúdo apresentado por Jèze, qual seja, a de ser um ato-condição para realização daquelas despesas. Diríamos que se trata do antecedente necessário, em face de expresso princípio constitucional.

A diferença é que Jèze chama o Orçamento de ato-condição apenas no caso das despesas discricionárias, enquanto que, no caso de despesas que possuem outro fundamento legal, o Orçamento não possuiria nenhuma significação jurídica.

De acordo com Jèze, o máximo de eficácia jurídica que a Lei de Orçamento pode possuir é a de ser a condição que possibilita aos servidores públicos exercer, regularmente, as competências indispensáveis para a realização dos atos jurídicos necessários à criação das despesas. No máximo, a lei orçamentária seria um ato-condição, visto que, com relação a uma série de despesas, não possuiria qualquer significação jurídica. Esse seria o caso de dívidas existentes e de pensões concedidas. Com relação a estas, o princípio do respeito aos direitos subjetivos se oporia a que o pagamento fosse, de qualquer maneira, impedido. Nesses casos, o próprio Parlamento se encontraria perante um dever jurídico de incluir as dotações necessárias no Orçamento, sem qualquer apreciação discricionária ${ }^{456}$.

Nesse aspecto, entende-se que o Orçamento não é apenas um ato-condição, na terminologia de Jèze. Isso porque as despesas discricionárias se efetivam, na maioria das vezes, por meio de contratos. Ora, no ordenamento jurídico brasileiro um elemento integrante dos $\operatorname{contratos}^{457}$ - aliás, cláusula necessária - é, justamente, a previsão

\footnotetext{
${ }^{455}$ Art. 167, II, CF/88.

456 JÈZE, Gaston. Cours de Science des Finances et de Législation Financière Française. Sixième Édition. Paris: Marcel Giard, 1922, p. 25/26.

${ }^{457}$ Nos termos do art. $7^{\circ}, \S 2^{\circ}$, inciso II, da Lei 8.666/93, as obras e os serviços somente poderão ser licitados quando houver previsão de recursos orçamentários que assegurem o pagamento das obrigações decorrentes
} 
orçamentária, revelada por meio do prévio empenho ${ }^{458}$. Portanto, a previsão orçamentária se constitui em elemento integrante necessário da fonte geradora da obrigação, ou seja, do contrato. Como afirma Paulo Nader:

O contrato resulta da conjunção da vontade declarada e da lei. Esta fixa as condições essenciais à formação, bem como alguns dos efeitos jurídicos que produz; a declaração de vontade personaliza a aplicação do instituto jurídico, individuando o seu objeto e os deveres das partes. Os contratantes amoldam a lei, dentro do que esta apresenta de flexível, aos seus interesses, criando o seu dever ser (dasein). Pode-se afirmar que as cláusulas contratuais são um prolongamento da lei, daí dizer-se que o contrato faz lei

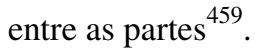

Ademais, como destaca Sainz de Bujanda, a falta de autorização orçamentária acarreta a ilegalidade de toda a atividade administrativa de realização da despesa pública, fato esse ignorado por Jèze:

La autorización presupuestaria es un efecto de la ley mediante en cual se atribuye al Gobierno la competencia para disponer de los fondos públicos dentro de unos determinados límites temporales, cuantitativos y cualitativos. La falta de autorización presupuestaria determina la ilegalidad de toda la actividad administrativa de realización del gasto público. Pero las obligaciones del Estado que dan lugar al gasto público no nacen de la autorización presupuestaria, sino de actos o de hechos que son exteriores y ajenos a ella ${ }^{460}$.

Em síntese, há que se ressaltar as seguintes conclusões: i) a previsão orçamentária se constitui, em relação às despesas constitucionais ou legais obrigatórias na condição necessária para que aquelas despesas possam ser realizadas, em face de princípio constitucional expresso; destarte, muito embora a Lei de Orçamento não seja, para tais

de obras ou serviços a serem executadas no exercício financeiro em curso, de acordo com o respectivo cronograma. $\mathrm{O}$ artigo 14 do referido diploma também determina que nenhuma compra será feita sem a adequada caracterização de seu objeto e indicação dos recursos orçamentários para seu pagamento, sob pena de nulidade do ato e responsabilidade de quem lhe tiver dado causa. Em relação ao contrato, o art. 55, inciso $\mathrm{V}$, do mesmo diploma insere como claúsula necessária o crédito pelo qual correrá a despesa, com a indicação da classificação funcional programática e da categoria econômica.

${ }^{458}$ Como destaca José Afonso da Silva, "Apesar do texto expresso do art. 58 da Lei n. 4.320, estamos inclinados a admitir que o nosso empenho, em geral, não passa também de ato meramente formal, que não cria, nem extingue, nem modifica nada; simplesmente registra, certifica, faz constar, verifica, e especialmente reserva recurso comprometido por ajustes, que o precedem ou, no máximo, lhe são concomitantes". SILVA, José Afonso da. Orçamento-Programa no Brasil. São Paulo: Revista dos Tribunais, 1973, p. 339. E, mais adiante, cita precioso excerto de Rudá de Andrade, em que este autor destaca: "O empenho foi criado para controlar o emprego de uma dotação, evitando anulações por falta de verba orçamentária ao pagamento a ser feito, proporcionando, ao mesmo tempo, às diversas repartições do Governo conhecerem, sucessiva e regularmente, as parcelas comprometidas pelas despesas já efetuadas, ou em perspectivas de liquidação ou pagamento". Apontamentos de Ciência das Finanças, p. 225, 2a ed., Rio de Janeiro, José Konfino Editor, 1966. Apud SILVA, José Afonso, op. cit., p. 339.

${ }^{459}$ NADER, Paulo. Curso de Direito Civil. Vol. 3. Contratos. Rio de Janeiro: Forense, 2009, p. 4.

460 SAINZ DE BUJANDA, Fernando. Lecciones de Derecho Financiero. $7^{\mathrm{a}}$ ed. Madrid: Universidad Complutense, 1989, p. 444. 
espécies de despesas, o seu fundamento legal, a previsão orçamentária confere legitimidade à realização dos gastos; ii) para as despesas discricionárias, a Lei de Orçamento se constitui em seu fundamento legal primário, conferindo a possibilidade de que tais despesas possam ser efetivamente realizadas; além disso, a previsão orçamentária, nesses casos, se constitui em elemento integrante e constitutivo da fonte geradora da obrigação, especificamente, o contrato; tais circunstâncias, em nosso ordenamento, indicam a insuficiência da tese de Jèze, que aponta, nessa circunstância, que o Orçamento seria um ato-condição; e iii) o fato de haver, no sistema orçamentário brasileiro, um elevado grau de rigidez orçamentária que não atenta quanto ao fato de que a LOA pode se constituir em fundamento legal primário das despesas discricionárias; tal circunstância não macula a força da qual se pode revestir a lei orçamentária.

\title{
4.5.2 Dotações orçamentárias e seu conteúdo jurídico
}

A dotação orçamentária pode ser definida como o limite financeiro atribuído ao crédito orçamentário da Lei de Orçamento ou aos créditos adicionais. Desse modo, estruturada a lei orçamentária na forma de vários créditos orçamentários, a estes devem ser associados os respectivos limites financeiros para o desempenho dos programas de trabalho previstos.

A respeito da diferenciação entre créditos orçamentários e dotações, é lúcida a explicação trazida por Giacomoni:

\begin{abstract}
A lei orçamentária é organizada na forma de créditos orçamentários, aos quais estão consignadas dotações. Em conseqüência da imprecisão com que são utilizadas na legislação, é comum o emprego das expressões crédito orçamentário e dotação como sinônimos. Na realidade, o crédito orçamentário é constituído pelo conjunto de categorias classificatórias e contas que especificam as ações e operações autorizadas pela lei orçamentária. No âmbito do orçamento federal brasileiro, a partir do exercício de 2000, o crédito orçamentário individualizado compreende o seguinte conjunto de categorias classificatórias presentes na lei orçamentária: Grupo de Despesa, Identificador de Uso, Fonte de Recursos, Modalidade de Aplicação, Categoria Econômica, Subtítulo, Projeto ou Atividade ou Operação Especial, Programa, Função, Unidade Orçamentária e Órgão. Por seu turno, dotação é o montante de recursos financeiros com que conta o crédito orçamentário ${ }^{461}$.
\end{abstract}

A concepção clássica da Lei de Orçamento sempre se inclinou a considerar as dotações como limites máximos disponibilizados ao Executivo, para o cumprimento dos

${ }^{461}$ GIACOMONI, James. Orçamento Público. 14a ed. São Paulo: Atlas, 2007, p. 294. 
programas governamentais. Para justificar tal entendimento, Laband destacava, sobretudo, razões de ordem prática, que evidenciavam, em ocasiões diversas, a impossibilidade de execução de determinada dotação, tal como prevista na Lei de Orçamento; além disso, já antecipava considerações relativas à economia de recursos:

\begin{abstract}
la inclusión de un gasto en la ley presupuestaria no entrañe ninguna obligación coactiva para el Gobierno, en el sentido de que haya de llevar a cabo realmente dicho gasto. La realización de un gasto previsto en el Presupuesto es en algunos casos imposible, por ejemplo, cuando un jubilado del Estado muere al iniciarse el año presupuestario, cuando se retrasa el nombramiento de la persona que haya de ocupar un puesto vacante, cuando nadie se presenta a un premio del Estado, etc. En otros muchos casos es posible resolver una de las funciones previstas por la Administración con unos costes menores de lo que el Gobierno y el Parlamento habían estimado. (...) En todos estos casos sería pura insensatez considerar que el Gobierno está obligado a la prestación de tales gastos por estar previstos en la ley presupuestaria ${ }^{462}$.
\end{abstract}

Também já se encontram, no pensamento labandiano, reflexões sobre a política fiscal, que poderiam indicar a necessidade de não se despender todas as dotações orçamentárias previstas no Orçamento:

Pero exactamente igual, el Gobierno también puede tener razones de otra especie para omitir unos gastos autorizados en el Presupuesto, especialmente cuando amenazadoras circunstancias políticas exigen la momentánea acumulación de capital o cuando los ingresos son inferiores a los estimados en el Presupuesto, de forma que sea de temer un déficit $^{463}$.

Gaston Jèze também atribuía às dotações orçamentárias o caráter de limite máximo de gastos:

La autorización parlamentaria (crédito) determina (...) de manera precisa, la suma máxima hasta la concurrencia de la cual el ministro está autorizado para realizar - con determinado objeto - actos jurídicos (contratos) que originen deudas de sumas de dinero a cargo del patrimonio administrativo nacional ${ }^{464}$.

Mesmo entre autores não inclinados às concepções dos autores clássicos, vislumbra-se o entendimento de dotações como limites máximos franqueados ao Poder Executivo:

(...) respecto a los gastos públicos, el Presupuesto produce efectos jurídicos bien precisos en un triple sentido: autorizar a la Administración a realizar el gasto público;

${ }^{462}$ LABAND, Paul, op. cit., p. 93.

${ }^{463}$ Ibid., p. 93.

464 JÈZE, Gaston. Principios Generales del Derecho Administrativo. Tomo IV. Traducción directa de la $3^{\mathrm{a}}$ edición francesa, por Julio N. San Millán Almagro. Buenos Aires: Editorial Depalma, 1950, p. 16. 
limitar las cantidades a gastar hasta un determinado montante y fijar el empleo o destino que haya de darse a los créditos aprobados en el Presupuesto ${ }^{465}$.

No mesmo sentido, Burkhead defende que "a autorização orçamentária deve ter um sentido de permissão, não de ordem, isto é, deve conceder autoridade para assumir obrigações e para realizar despesas, não exigir que elas sejam feitas"466.

Tal orientação relativa à concepção das dotações orçamentárias é inclinação dominante na maioria dos ordenamentos jurídicos estrangeiros. Nesse aspecto, se apresentam as concepções francesa $^{467}$, chilena ${ }^{468}$, portuguesa ${ }^{469}$ e mesmo norteamericana $^{470}$. Analisando o ordenamento jurídico português, Canotilho e Vital Moreira expõem o referido entendimento:

Quanto ao orçamento das despesas, as respectivas dotações são o limite máximo, que não pode ser ultrapassado, mas não implica obviamente qualquer obrigação de o atingir, salvo quando tal obrigação resultar da lei, de contrato ou do próprio orçamento ${ }^{471}$.

O texto constitucional pátrio parece se inclinar para a concepção de dotações como limites máximos ou tetos de despesas a serem realizadas. Não por outro motivo, a Constituição Federal de 1988 vedou a realização de despesas que excedessem os créditos orçamentários ou adicionais $^{472}$. Ou seja, não se vedou a realização de despesas que se contivessem dentro dos limites financeiros atribuídos aos créditos orçamentários.

O art. 27 da Lei $\mathrm{n}^{\circ}$ 4.320/64, em sintonia com a Carta de 1988, também reforça tal orientação:

Art. 27. As propostas parciais de orçamento guardarão estrita conformidade com a política econômico-financeira, o programa anual de trabalho do Governo e, quando fixado, o limite global máximo para o orçamento de cada unidade administrativa (g.n.).

465 SAINZ DE BUJANDA, Fernando. Lecciones de Derecho Financiero. $7^{\mathrm{a}}$ ed. Madrid: Universidad Complutense, 1989, p. 432.

${ }^{466}$ BURKHEAD, Jesse. Orçamento Público. Rio de Janeiro: Fundação Getúlio Vargas, 1971, p. 451.

467 Artigos $9^{\circ}$ e 10 da Lei Orgânica das Leis de Finanças da França (LOLF).

${ }^{468}$ Artigo $9^{\circ}$ do Decreto-lei no 1.263/75 (Lei Orgânica de Administração Financeira do Chile), pelo qual "los presupuestos de gastos son estimaciones del límite máximo a que pueden alcanzar los egresos y compromisos públicos".

469 Artigo 42 da Lei de Enquadramento Orçamental do Estado Portuguesa (LEOE), segundo o qual "as dotações constantes do orçamento das despesas constituem o limite máximo a utilizar na realização destas".

${ }^{470}$ BLÖNDAL, Jón R.; KRAAN, Dirk-Jan; RUFFNER, Michael. Budgeting in the United States. OECD Journal on Budgeting. V. 3, n. 2, 2003, p. 43.

${ }^{471}$ CANOTILHO, J. J. Gomes; MOREIRA, Vital. Constituição da República Portuguesa Anotada. Vol. 1. $1^{\text {a }}$ ed. brasileira/4ª ed. portuguesa. São Paulo: Revista dos Tribunais e Coimbra Editora, 2007, p. 1113.

${ }^{472}$ Art. 167, II, CF/88. 
$\mathrm{O}$ art. 70 da Constituição da República determina aincidência dos princípios da legalidade, legitimidade e economicidade sobre a atividade administrativa de execução do Orçamento. Dessa forma, o administrador público deve pautar sua conduta orientado por tais vetores, além de prestar contas de sua atividade, inclusive quanto ao respeito aos aludidos princípios no desenvolvimento da atividade administrativa, notadamente aquela relativa à execução da Lei de Orçamento.

Ademais, o texto constitucional também é explícito Quanto à observância da eficácia e eficiência da gestão orçamentária dos órgãos e entidades da administração federal, assim como da necessidade de avaliação dos resultados da ação pública, seja das metas previstas no PPA, seja da execução dos programas e do Orçamento da União. Nos termos do art. 74 da Carta de 1988, in verbis:

Art. 74. Os Poderes Legislativo, Executivo e Judiciário manterão, de forma integrada, sistema de controle interno com a finalidade de:

I - avaliar o cumprimento das metas previstas no plano plurianual, a execução dos programas de governo e dos orçamentos da União;

II - comprovar a legalidade e avaliar os resultados, quanto à eficácia e eficiência, da gestão orçamentária, financeira e patrimonial nos órgãos e entidades da administração federal, bem como da aplicação de recursos públicos por entidades de direito privado;

Portanto, a observância dos princípios da eficácia, eficiência e economicidade acarreta a necessidade de uma atuação absolutamente responsável à frente da gestão orçamentária e financeira do Governo. Para isso, há que se buscar atingir resultados com um mínimo de custos ou com o menor dispêndio de recursos, ao mesmo tempo em que se prima pela excelência da qualidade dos serviços prestados.

Nesse aspecto, a observância dessa principiologia constitucional termina por ser contrária à necessidade de exaurimento das dotações constantes da Lei de Orçamento. Afinal, se o mesmo resultado pode ser obtido a custos menores para a sociedade, nenhum sentido há em se obrigar a que sejam gastos todos os recursos disponíveis em determinada dotação.

A doutrina também se inclina para o entendimento de que o princípio da eficácia, adotado em diversos ordenamentos jurídicos modernos, implica na adoção de métodos racionais de avaliação das despesas necessárias, de modo a se evitar os desperdícios no trato com a coisa pública. Nas palavras de Moncada: 
No âmbito do direito orçamental já se viu que a eficácia requer certos métodos racionais de avaliação e descrição das despesas públicas, em ordem a evitar desperdícios, nos antípodas dos tradicionais métodos automáticos de cálculo das despesas ${ }^{473}$.

Outra ordem de considerações revela o caráter de autorização e de limite máximo de recursos, de que se encontram revestidas as dotações orçamentárias. Considerando a existência das metas fiscais, que representam, em termos práticos, a linha condutora da política fiscal do Governo e que implicam em determinada proporção entre receitas e despesas primárias, a ser observada e garantida pela Administração Pública, deve-se ressaltar que a realidade ou situação econômica poderá indicar a necessidade de limitação de empenho. Quanto a isso, a obrigatoriedade de execução de despesas encontra-se em sentido oposto a eventuais necessidades de contingenciamento, que estão respaldadas em nosso ordenamento jurídico.

A limitação de empenho nada mais é do que o provisório impedimento de movimentação dos limites orçamentários atribuídos a determinada unidade orçamentária. Consta de forma explícita no art. $9^{\circ}$ da Lei de Responsabilidade Fiscal, in verbis:

\begin{abstract}
Art. 9ํㅗ Se verificado, ao final de um bimestre, que a realização da receita poderá não comportar o cumprimento das metas de resultado primário ou nominal estabelecidas no Anexo de Metas Fiscais, os Poderes e o Ministério Público promoverão, por ato próprio e nos montantes necessários, nos trinta dias subseqüentes, limitação de empenho e movimentação financeira, segundo os critérios fixados pela lei de diretrizes orçamentárias.

$\S 1^{\circ}$ No caso de restabelecimento da receita prevista, ainda que parcial, a recomposição das dotações cujos empenhos foram limitados dar-se-á de forma proporcional às reduções efetivadas.

$\S 2^{\circ}$ Não serão objeto de limitação as despesas que constituam obrigações constitucionais e legais do ente, inclusive aquelas destinadas ao pagamento do serviço da dívida, e as ressalvadas pela lei de diretrizes orçamentárias.
\end{abstract}

Ademais, deve-se lembrar que a fixação das cotas orçamentárias, em nosso ordenamento, procura compatibilizar, dentro do possível, dois objetivos fundamentais: i) assegurar às unidades orçamentárias a soma de recursos necessários à melhor execução do programa anual de trabalho; e ii) manter, durante o exercício, dentro do possível, o equilíbrio entre a receita arrecadada e a despesa realizada ${ }^{474}$.

Tais dispositivos, constantes do ordenamento brasileiro, não se compatibilizam com a obrigatoriedade de execução das dotações consignadas ou exaurimento dos recursos orçamentários atribuídos.

${ }^{473}$ MONCADA, Luís S. Cabral de. Direito público e eficácia. In: Estudos de Direito Público. Coimbra Editora, 2001, p. 175.

${ }^{474}$ Art. 48 da Lei no 4.320/64. 
Em outros termos, a importância do equilíbrio das contas públicas, mediante a consecução da meta de resultado primário estabelecida para cada exercício, muitas vezes acarreta a necessidade de contingenciamento de despesas, reforçando o caráter autorizativo da Lei Orçamentária Anual, relativamente às dotações, o que implica na não obrigatoriedade da execução de todas as despesas.

Por último, questões práticas, já destacadas por Laband, também indicam que não há como se obrigar a um exaurimento das dotações, visto que motivos concretos poderão implicar em impossibilidade de esgotamento dos recursos orçamentários. Exemplo disso são as dificuldades operacionais havidas com atrasos em obras e licitações, a necessidade de obtenção de certificações ambientais, além de um sem-número de obstáculos que impedem a utilização dos recursos constantes da Lei de Orçamento. Como destaca Giacomoni:

\begin{abstract}
Uma terceira razão que contribui para a não-execução de créditos autorizados no orçamento é a ocorrência de situações que impedem o início ou atrasam o prosseguimento e a conclusão de obras e serviços. Nas atividades governamentais, são muitas as providências desenvolvidas entre a fase da autorização orçamentária e a realização propriamente dita da despesa. Podem-se apontar algumas: elaboração de projetos, orçamentos e memoriais de execução, desapropriações, fase licitatória com freqüentes atrasos em face de querelas judiciais, elaboração de contratos, entre outras ${ }^{475}$.
\end{abstract}

Portanto, as dotações orçamentárias, em nosso ordenamento, são autorizações de gasto franqueadas ao Executivo para a execução das ações e respectivos programas orçamentários. Não há qualquer dispositivo que atribua obrigatoriedade de exaurimento das dotações constantes da Lei de Orçamento.

No ordenamento brasileiro, muito embora não se encontrem expressamente previstas na legislação, pode-se distinguir a existência de duas espécies de dotações orçamentárias: limitativas e estimativas. Quanto a tal aspecto, a concepção brasileira assemelha-se àquela em vigor no ordenamento jurídico francês.

As dotações estimativas são aquelas que, por representarem a expressão monetária atribuída a despesas de caráter obrigatório fixadas pela legislação brasileira, possuem, como nota dominante, o caráter de previsão da soma necessária à satisfação dos encargos estabelecidos por meio de outras leis ou mesmo da Constituição. Em outras palavras, nessa primeira espécie de dotação, procura-se antecipar o volume estimado dos recursos que serão necessários ao cumprimento das obrigações estabelecidas por outras leis.

${ }^{475}$ GIACOMONI, James. Orçamento Público. 14a ed. São Paulo: Atlas, 2009, p. 287. 
No caso de dotações estimativas, não há qualquer discricionariedade por parte do Executivo em gastar mais ou menos recursos do que aqueles que se encontram previstos. As circunstâncias concretas do caso ditarão a necessidade de maior ou menor parcela de recursos para atender àquela obrigação governamental, visto que se trata, no fundo, da consignação de recursos para o atendimento de despesas constitucionais ou legais obrigatórias.

Por sua vez, as dotações limitativas possuem, como traço característico fundamental, o fato de serem tetos de gastos ou limites traçados pelo Congresso ao Executivo. Encontram-se diretamente relacionadas às despesas discricionárias e representam, em termos de volume, a menor parcela do nosso orçamento, cerca de $10 \%$. Seu traço marcante é o fato de facultarem a utilização de certo montante de recursos, até determinado limite, para a execução da respectiva ação e/ou programa governamental a que se vinculam.

Todavia, não se pode deixar de considerar que, em certo sentido, todas as dotações são estimativas, pois, em determinados casos, poderão ser necessários mais recursos para o alcance dos objetivos previstos, enquanto que em outros, poderá haver dispêndio a menor do que aquele inicialmente previsto, caso em que a atuação governamental poderá ter se revelado eficiente e eficaz para cumprir os objetivos fixados com menor volume de recursos.

De qualquer forma, sejam dotações limitativas ou estimativas, o que sobressai da análise deste elemento da despesa constante da LOA é seu nítido viés de limite ou autorização máxima de gasto.

Pelo fato de as análises da lei orçamentária terem se concentrado, exclusivamente, no exame da dotação orçamentária, chegou-se à errônea conclusão de que essa lei é meramente autorizativa. Ou seja, visto que as dotações orçamentárias representam limites máximos de gasto ou tetos para as despesas, que não precisam, de maneira obrigatória, ser integralmente despendidas pelo Executivo, extraiu-se a conclusão de que todo o orçamento é autorizativo.

Tal conclusão não é, de modo algum, correta. Somente se pode concordar com esta afirmação quando se vislumbra que as dotações não precisam ser obrigatoriamente exauridas. Todavia, disso não se pode concluir que toda a lei orçamentária seja autorizativa. 
Resumidamente, há, em cada dotação orçamentária consignada na Lei de Orçamento, dois comandos concomitantes: autorização e proibição. Autorização para utilização de certo volume de recursos na execução de determinada ação orçamentária e proibição de se exceder o teto de recursos consignados.

As dotações orçamentárias, portanto, são, ao mesmo tempo, autorização, por facultarem ao Executivo a utilização de um montante de recursos financeiros, e proibição, por vedarem ao Poder Executivo utilizar soma maior de recursos do que aqueles atribuídos, à exceção, é claro, de eventual reforço de dotação.

\subsubsection{Programas orçamentários e Metas programáticas}

\subsubsection{Estruturação por Programas}

A estruturação programática do Orçamento fundamenta-se na principal categoria que compõe a Lei Orçamentária: o programa. Tal estruturação baseia-se no fato de que toda ação de Governo encontra-se atualmente organizada em programas orientados para a realização de objetivos estratégicos definidos para o período do Plano Plurianual ${ }^{476}$.

A estruturação do Orçamento por meio de programas já era exigência do ordenamento brasileiro desde antes da instauração do novo regime constitucional, conforme destaca José Afonso da Silva:

a classificação por programa é exigência legal no Brasil, desde a promulgação da Lei ${ }^{\circ}$ 4.320/64, que dispôs que a lei orçamentária conterá a discriminação da receita e da despesa de forma a evidenciar a política econômico-financeira e o programa de trabalho do governo, prevendo, além disso, que as receitas e despesas de capital constituam objeto de planos plurianuais de no mínimo três anos, correlacionados os programas a metas objetivas em termos de realização de obras e prestação de serviços (arts. $2^{\circ}, 9^{\circ}$ e segs., 23 a 26$)^{477}$.

No mesmo sentido, o Decreto-lei no 200/67 também já previa a necessidade de elaboração de um orçamento-programa, que pormenorizaria a etapa do programa

\footnotetext{
${ }^{476}$ SECRETARIA DE ORÇAMENTO FEDERAL. Manual Técnico de Orçamento - MTO 2009, p. 41. Brasília, 2008.

${ }^{477}$ SILVA, José Afonso da. Orçamento-Programa no Brasil. São Paulo: Editora Revista dos Tribunais, 1973, p. $64 / 65$.
} 
plurianual a ser realizada no exercício seguinte, além de servir de roteiro à execução coordenada do programa anual $^{478}$.

A tentativa de introduzir, de forma ampla e sistemática, as categorias programáticas nos orçamentos públicos no Brasil, se deu com a edição da Portaria $n^{\circ}$ 9/74, que instituiu a classificação funcional-programática ${ }^{479}$.

A Constituição Federal de 1988 não adotou, de forma explícita e taxativa, esse modelo de estruturação do Orçamento, muito embora tenha dispositivos que apontem nessa direção, de que são exemplos a determinação para que o PPA tratasse dos programas de duração continuada ${ }^{480}$ e a vedação do início de programas que não estivessem incluídos na lei orçamentária anual ${ }^{481}$.

Editada a Portaria 42/99, determinou-se a todos os entes federativos que estruturassem seus Orçamentos por meio de programas, com quatro categorias principais: programa, projeto, atividade e operações especiais ${ }^{482}$.

Dentro dessa concepção, o programa é considerado o módulo integrador entre o plano e o orçamento. Em conformidade com tal modelo, o plano termina no programa, enquanto que o orçamento tem início no programa, conferindo-se uma integração a esses instrumentos desde a origem ${ }^{483}$.

O Plano Plurianual 2008-2011 define o programa como o "instrumento de organização da ação governamental que articula um conjunto de ações visando à concretização do objetivo nele estabelecido" ${ }^{484}$.

Por sua vez, a Lei n ${ }^{\circ} 12.017 / 09$, LDO para 2010, dispõe, em seu art. 5º, programa como o "instrumento de organização da ação governamental visando à concretização dos objetivos pretendidos, sendo mensurado por indicadores estabelecidos no plano plurianual”. Idêntica definição encontra-se fixada na Portaria n ${ }^{\circ} 42 / 99$, do Ministério do Planejamento, Orçamento e Gestão ${ }^{485}$.

Para José Afonso da Silva, o programa apresenta a seguinte definição:

Programa é a categoria orçamentária constituída de um conjunto de ações necessárias para alcançar um objetivo ou meta, mediante a integração de um conjunto de esforços

\footnotetext{
${ }^{478}$ Art. 16 do Decreto-lei no 200/67.

${ }^{479}$ GIACOMONI, James. Orçamento Público. $14^{\text {a }}$ ed. São Paulo: Atlas, 2007, p. 97.

${ }^{480}$ Art. $165, \S 1^{\circ}, \mathrm{CF} / 88$.

${ }^{481}$ Art. $167, \mathrm{I}, \mathrm{CF} / 88$.

${ }^{482}$ Art. $2^{\circ}$ da Portaria no 42/99 do Ministério do Planejamento, Orçamento e Gestão.

${ }^{483}$ SECRETARIA DE ORÇAMENTO FEDERAL, op. cit., p. 41.

${ }^{484}$ Art. $4^{\circ}$, I, da Lei $n^{\circ} 11.653 / 08$ (PPA para 2008-2011).

485 Art. $2^{\circ}$, 'a', da Portaria n ${ }^{\circ} 42$, de 14 de abril de 1999, do Ministro de Estado do Orçamento e Gestão.
} 
de recursos humanos, materiais e financeiros a ele consignados, com a determinação dos custos globais e cuja execução cabe a uma ou mais unidades orçamentárias ${ }^{486}$.

As informações principais do Programa são: i) problema a ser resolvido; ii) objetivo; iii) público-alvo; e iv) indicadores ${ }^{487}$. A esses, pode-se acrescentar, conforme a definição de José Afonso da Silva, as dotações orçamentárias, isto é, recursos financeiros associados aos programas; as ações, que representam um desmembramento dos programas em atividades ou projetos, para a consecução das finalidades estabelecidas; e a unidade orçamentária responsável pela execução das atividades do programa.

O elemento central do programa, conforme se depreende das definições apresentadas, é o objetivo, que representa, em última instância, a própria razão de existência da categoria programática. $\mathrm{O}$ objetivo encontra-se diretamente relacionado ao problema social que ensejou a necessidade de uma intervenção estatal.

O objetivo do programa expressa o "resultado que se deseja alcançar, ou seja, a transformação da situação a qual o programa se propõe modificar. Deve ser expresso de modo conciso, evitando a generalidade, dando a idéia do que se pretende de forma clara, categórica e determinante" ${ }^{, 488}$.

O público-alvo identifica o grupo de pessoas, setores e comunidades que se beneficia direta e legitimamente com a execução de um determinado programa; e sua importância encontra-se relacionada à necessidade de seleção e priorização das diversas ações que compõem o programa ${ }^{489}$.

$\mathrm{O}$ indicador representa o instrumento capaz de mensurar o desempenho obtido por certo programa. Deve ser passível de aferição, de forma coerente com o objetivo estabelecido, além de se mostrar sensível à contribuição das principais ações e apurável em tempo oportuno ${ }^{490}$.

A seleção do indicador parte da definição do objetivo fixado para um determinado programa ou política pública, viabilizando o acompanhamento das ações que o compõem em termos de eficiência, eficácia e efetividade ${ }^{491}$.

Dentro da representação clássica do ciclo de formulação e avaliação de programas (diagnóstico, formulação, implementação e avaliação), cada etapa do ciclo envolve o uso

\footnotetext{
${ }^{486}$ SILVA, José Afonso da, op. cit., p. 116.

${ }^{487}$ SECRETARIA DE ORÇAMENTO FEDERAL, op. cit., p. 35.

${ }^{488}$ Ibid., p. 42.

${ }^{489}$ Ibid., p. 42.

${ }^{490}$ Ibid., p. 43.

${ }^{491}$ JANNUZZI, Paulo de Martino, op. cit., p. 139.
} 
de indicadores de diferentes naturezas e $\operatorname{propriedades}^{492}$, para que se possibilite um razoável desenho do programa e uma ampla avaliação dos resultados auferidos. A importância dos indicadores é salientada em várias análises do tema, como se visualiza a seguir:

\begin{abstract}
Considerando que os programas são construídos para enfrentar problemas e demandas na sociedade, os indicadores constituem a principal medida do resultado da atuação governamental para a verificação do alcance de seus objetivos ao longo do tempo. Para que isso ocorra, é importante que o problema ao qual se refira o programa esteja bem definido e adequadamente descrito por informações da realidade que deverão integrar o indicador, juntamente com aquelas relativas às mais importantes ações que atacarão o problema. Do contrário, não será possível verificar mudanças no problema nem tampouco associar os resultados ao desempenho das ações ${ }^{493}$.
\end{abstract}

Os programas encontram-se, na estrutura orçamentária federal, desdobrados em ações. As ações são operações das quais resultam produtos (bens ou serviços), que contribuem para atender ao objetivo de um programa, e podem ser classificadas, conforme seu traço distintivo principal, em atividades, projetos e operações especiais ${ }^{494}$. As atividades, projetos e operações especiais são detalhadas em subtítulos, utilizados especialmente para especificar a localização física da ação ${ }^{495}$.

O produto representa o bem ou serviço que resulta da ação, destinado ao públicoalvo ou o investimento para a respectiva. Por sua vez, a unidade de medida corresponde ao padrão selecionado para mensurar a produção do bem ou serviço ${ }^{496}$.

Outro componente relevante da programação física e financeira é a meta física. A meta física corresponde à quantidade de produto a ser ofertada por ação, de forma regionalizada, para o período de um ano, sendo indicada em nível de subtítulo ${ }^{497}$.

Com vistas a tornar mais clara a exposição, remete-se ao caso concreto de um programa orçamentário, para que se evidenciem os conceitos anteriormente expostos. $\mathrm{O}$ programa Erradicação do Trabalho Infantil (0068) apresenta-se discriminado da seguinte forma na Lei de Orçamento ${ }^{498}$ :

\footnotetext{
${ }^{492}$ JANNUZZI, Paulo de Martino, op. cit., p. 147/148.

${ }^{493}$ SECRETARIA DE PLANEJAMENTO E INVESTIMENTOS ESTRATÉGICOS. Manual de Avaliação Plano Plurianual 2008/2011. Brasília, 2009, p. 13.

${ }^{494}$ SECRETARIA DE ORÇAMENTO FEDERAL. Manual Técnico de Orçamento - MTO 2009. Brasília: 2008 , p. 45.

${ }^{495}$ Ibid., p. 48.

${ }^{496}$ Ibid., p. 46.

${ }^{497}$ Ibid., p. 50.

498 Lei $\mathrm{n}^{\text {o }} 11.897 / 08$ (LOA de 2009), Vol. IV, p. 349. Disponível em [https://www.portalsof.planejamento.gov.br/sof/2009/VOL_IV.pdf]. Acesso em 28.09.2009.
} 
Programa 0068 - Erradicação do Trabalho Infantil

\begin{tabular}{|l|l|r|}
\hline 0068 & Erradicação do Trabalho Infantil & Valor \\
\hline & 2688 - Fiscalização para Erradicação do Trabalho Infantil & 3.600 .000 \\
\hline & - Criança e adolescente com situação regularizada (unidade): 22500 & 72.000 \\
\hline & 4731 - Atualização do Mapa de Focos de Trabalho Infantil & \\
\hline & - Mapa publicado (unidade): 1 & \\
\hline
\end{tabular}

O referido programa encontra-se inserido nas atribuições do Ministério do Trabalho e Emprego (órgão 38.000) e possui o seguinte objetivo: "Retirar crianças e adolescentes com idade inferior a 16 anos da prática do trabalho precoce, exceto na condição de aprendiz a partir de 14 anos"

O indicador selecionado para o acompanhamento da evolução e dos resultados do programa é a taxa de trabalho infantil - percentagem -.

Esse programa é composto por duas ações ${ }^{500}$ : i) fiscalização para erradicação do trabalho infantil; e ii) atualização do mapa de focos do trabalho infantil.

No caso da atividade 2688 - fiscalização -, encontra-se prevista a regularização da situação de 22.500 crianças, a ser custeada com recursos no montante de $\mathrm{R} \$ 3.600 .000,00$. O produto - bem ou serviço - dessa ação são as crianças e adolescentes com situação regularizada, enquanto que a unidade de medida utilizada para a mensuração da ação estatal é o número - unidade - de crianças a serem retiradas do trabalho precoce. Portanto, no caso dessa ação, a meta física é a de regularizar a situação de 22.500 crianças/adolescentes, que devem ser retirados da prática do trabalho precoce, no período de um ano.

Para a atividade 4731 - atualização do mapa -, prevê-se a publicação do mapa de focos do trabalho infantil atualizado, com dotação orçamentária no valor de $\mathrm{R} \$ 72.000,00$. Nesse caso, o produto da ação é o mapa publicado, e a respectiva unidade de medida é o número de mapas atualizados, no caso um mapa. A meta física, assim, é representada pela atualização de um mapa de focos do trabalho infantil, no período de um ano.

Por último, deve-se salientar que, os programas, em seu conjunto, integram objetivos mais amplos, seja no nível setorial, seja em nível estratégico ou de Governo.

\footnotetext{
${ }^{499}$ Lei no 11.653/08 (PPA 2008-2011), Anexo I - Programas de Governo Finalísticos, p. 299. Disponível em [http://www.planejamento.gov.br/secretarias/upload/Arquivos/spi/plano_plurianual/PPA/081015_PPA_2008 _Anexo1.pdf]. Acesso em 30.09.2009.

500 Constam outras ações do referido programa como integrantes do Orçamento da Seguridade Social. Todavia, tais ações não foram consideradas nesta exposição ilustrativa, que teve como eixo condutor os programas e ações constantes do Orçamento Fiscal.
} 
Dessa forma, a par do objetivo imediato orientador do próprio programa, no PPA aparecem discriminados os objetivos setoriais e os objetivos de governo aos quais se encontra vinculado o programa.

No caso do programa Erradicação do Trabalho Infantil, constam os seguintes: “i) Objetivo de Governo: Promover o acesso com qualidade à Seguridade Social, sob a perspectiva da universalidade e da equidade, assegurando-se o seu caráter democrático e a descentralização; e ii) Objetivo Setorial: Consolidar o sistema único de assistência social e ampliar a rede de proteção e promoção social" ${ }^{501}$.

Tomemos um segundo exemplo. O programa Transferência de Renda com Condicionalidades - Bolsa Família (1335), a cargo do Ministério do Desenvolvimento Social e Combate à Fome, está estruturado, na Lei de Orçamento, na seguinte conformidade ${ }^{502}$ :

Programa 1335 - Transferência de Renda com Condicionalidades - Bolsa Família

\begin{tabular}{|c|c|c|}
\hline 1335 & Transferência de Renda com Condicionalidades - Bolsa Família & Valor \\
\hline & 2227 - Gestão e Administração do Programa & 2.425 .000 \\
\hline & $\begin{array}{l}6414 \text { - Sistema Nacional para Identificação e Seleção de Público-Alvo para os } \\
\text { Programas Sociais do Governo Federal - Cadastro Único }\end{array}$ & 16.800 .000 \\
\hline & - Cadastro Válido (unidade): 9.324 .000 & \\
\hline & $\begin{array}{l}6524 \text { - Serviços de Concessão, Manutenção, Pagamento e Cessação dos } \\
\text { Benefícios de Transferência Direta de Renda }\end{array}$ & 218.954 .165 \\
\hline & - Benefício pago (milhar): 10.127 & \\
\hline & $\begin{array}{l}8442 \text { - Transferência de Renda Diretamente às Famílias em Condição de } \\
\text { Pobreza e Extrema Pobreza (Lei n }{ }^{\circ} 10.836 \text {, de 2004) }\end{array}$ & 11.434 .280 .000 \\
\hline & Família atendida (unidade): 11.101 .833 & \\
\hline & 8446 - Serviço de Apoio à Gestão Descentralizada do Programa Bolsa Família & 280.170 .001 \\
\hline & - Ente federativo apoiado (unidade): 5.056 & \\
\hline
\end{tabular}

O objetivo visado pelo programa Bolsa Família é o seguinte:

Contribuir para a redução da fome, da pobreza, da desigualdade e de outras formas de privação vividas pelas famílias mais excluídas, considerando três dimensões: o alívio imediato da pobreza, por meio da transferência de renda diretamente às famílias

${ }_{501}$ Lei no 11.653/08 (PPA 2008-2011), Anexo I - Programas de Governo Finalísticos, p. 299. Disponível em [http://www.planejamento.gov.br/secretarias/upload/Arquivos/spi/plano_plurianual/PPA/081015_PPA_2008 Anexo1.pdf]. Acesso em 30.09.2009.

502 Lei $\mathrm{n}^{\mathrm{o}} 11.897 / 08$ (LOA de 2009), Volume IV, p. 698. Disponível em [https://www.portalsof.planejamento.gov.br/sof/2009/VOL_IV.pdf]. Acesso em 28.09.2009. 
pobres e extremamente pobres; a contribuição para a redução da pobreza da geração seguinte, por meio do reforço do direito de acesso aos serviços de saúde e de educação, com o cumprimento das condicionalidades nestas áreas; e a articulação de ações complementares, de forma a desenvolver as capacidades das famílias beneficiárias. ${ }^{503}$

O público-alvo do programa são as famílias em situação de pobreza com renda per capita mensal de $\mathrm{R} \$ 60,00$ a $\mathrm{R} \$ 120,00$ e extrema pobreza com renda per capita mensal de até $\mathrm{R} \$ 60,00$.

Os indicadores constantes do Plano Plurianual para acompanhamento das ações desenvolvidas pelo programa e seus resultados são os seguintes: i) Grau de focalização do Programa Bolsa Família (\%); ii) Taxa de Acompanhamento das Condicionalidades de Educação (\%); iii) Taxa de Acompanhamento das Condicionalidades de Saúde (\%); e iv) Taxa de Atendimento às Famílias Pobres - porcentagem -.

O programa Bolsa Família é composto por cinco ações, quais sejam:

i) Gestão e Administração do programa;

ii) Sistema Nacional para Identificação e Seleção de Público-Alvo para os Programas Sociais do Governo Federal - Cadastro Único;

iii) Serviços de Concessão, Manutenção, Pagamento e Cessação dos Benefícios de Transferência Direta de Renda;

iv) Transferência de Renda Diretamente às Famílias em Condição de Pobreza e Extrema Pobreza; e

v) Serviço de Apoio à Gestão Descentralizada do Programa Bolsa Família.

Para cada uma das ações, à exceção da gestão e administração do programa, encontram-se previstos os produtos resultantes - bens ou serviços decorrentes da referida ação; as unidades de medidas utilizadas para a mensuração dos produtos resultantes da ação, bem como as metas físicas - quantidade de produto a ser ofertada por ação, de forma regionalizada, para o período de um ano. Além disso, à cada ação é associada uma dotação orçamentária, ou seja, os recursos financeiros previstos para o custeamento de cada atividade a ser desenvolvida.

Por fim, o programa Bolsa Família integra objetivos setoriais e de Governo, que se encontram previstos da seguinte forma: "i) Objetivo de Governo: Promover a inclusão

\footnotetext{
${ }^{503}$ Lei no 11.653/08 (PPA 2008-2011), Anexo I - Programas de Governo Finalísticos, p. 606. Disponível em [http://www.planejamento.gov.br/secretarias/upload/Arquivos/spi/plano_plurianual/PPA/081015_PPA_2008 _Anexo1.pdf]. Acesso em 30.09.2009.
} 
social e a redução das desigualdades; e ii) Objetivo Setorial: Contribuir para a redução da pobreza e da desigualdade" 504 .

A estruturação do Orçamento possuindo como categoria central do sistema orçamentário o programa é inclinação dominante nos ordenamentos jurídicos estrangeiros. As próprias definições a respeito do programa seguem essa tendência, apresentando-se muito assemelhadas.

No Chile, por exemplo, define-se o programa como: "Un conjunto de actividades necesarias, integradas y articuladas para proveer ciertos bienes y/o servicios (componentes), tendientes a lograr un propósito específico en una población objetivo de modo de resolver un problema o atender una necesidad que la afecte",505.

Embora com nomenclatura diferenciada na França, a essência é a mesma: os créditos orçamentários são agrupados por missões, e cada missão compreende o conjunto de programas concorrentes para uma política pública definida. Aos programas são associados objetivos precisos, bem como resultados esperados e submetidos à avaliação ${ }^{506}$.

No ordenamento mexicano, a programação e a orçamentação do gasto público são organizadas nos programas, nos termos seguintes:

las actividades que deberán realizar las dependências y entidades para dar cumplimiento a los objetivos, políticas, estrategias, prioridades y metas con base en indicadores de desempeño, contenidos en los programas que se derivan del Plan Nacional de Desarrollo y, en su caso, de las directrices que el Ejecutivo Federal expida en tanto se elabore dicho Plan, en los términos de la Ley de Planeación ${ }^{507}$.

Nos Estados Unidos, com a edição, em 1993, do Government Performance and Results Act - GPRA, foi introduzida a exigência de que as agências elaborassem planos estratégicos anuais e medidas de desempenho, além de relatórios associados aos resultados obtidos. As agências também deveriam definir sua missão, objetivos de longo prazo e

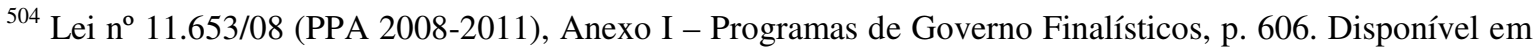
[http://www.planejamento.gov.br/secretarias/upload/Arquivos/spi/plano_plurianual/PPA/081015_PPA_2008 Anexo1.pdf]. Acesso em 30.09.2009.

505 CHILE, Ministerio de Hacienda, Dirección de Presupuestos. "Instrucciones del Formulario e Presentácion de Programas al Presupuesto", p. 02. Disponível em [http://www.dipres.cl/572/articles37391_doc_pdf.pdf]. Acesso em 22.05.09.

${ }^{506}$ Nos termos do art. $7^{\circ}$ da Lei de Finanças Francesa (LOLF): "Les crédits ouverts par les lois de finances pour couvrir chacune des charges budgétaires de l'Etat sont regroupés par mission relevant d'un ou plusieurs services d'un ou plusieurs ministères. Une mission comprend un ensemble de programmes concourant à une politique publique définie. Seule une disposition de loi de finances d'initiative gouvernementale peut creer une mission. (...) Un programme regroupe les crédits destinés à mettre en oeuvre une action ou un ensemble cohérent d'actions relevant d'un même ministère et auquel sont associés des objectifs précis, définís en fonction de finalités d'intérêt general, ainsi que des résultats attendus et faisant l'objet d'une évaluation (...)". ${ }^{507}$ Art. 24 da Ley Federal de Presupuesto y Responsabilidad Hacendaria mexicana. 
estratégias a serem utilizadas para atingir os resultados definidos ${ }^{508}$. Para avaliar os programas das entidades públicas, o OMB desenvolveu a ferramenta conhecida comoProgram Assessment Rating Tool-PART ${ }^{509}$, utilizada a partir de 2003.

Dessa maneira, muito mais do que um modismo, tal forma de estruturação e organização orçamentária representa um avanço no sentido de vincular os recursos financeiros a serem utilizados a determinados objetivos e metas. Os programas, nesse prisma, representam uma forma eficaz de alinhar e construir um moderno modelo de atuação governamental.

Há, ainda, outros aspectos de gestão desse modelo orçamentário que precisam ser destacados. Organizada e estruturada a ação governamental por meio dos programas, há que se construir um modelo de gestão que permita acompanhar e avaliar a implementação dos diversos programas.

Nesse sentido, a gestão do PPA para o quadriênio 2008-2011 é orientada para resultados, segundo os princípios de eficiência, eficácia e efetividade ${ }^{510}$. Compõe-se de dois níveis: estratégico e tático-operacional. O nível estratégico compreende a visão de longo prazo, os objetivos de governo e objetivos setoriais; o tático-operacional compreende os programas e as ações ${ }^{511}$.

No nível tático-operacional, a gestão do PPA compreende os Gerentes de Programa, os Gerentes-Executivos de Programa, os Coordenadores de Ação e os Coordenadores Executivos de Ação ${ }^{512}$.

A gestão de programas do Plano Plurianual é de responsabilidade do Gerente de Programa, em conjunto com o Gerente-Executivo, e a gestão da ação, do Coordenador de Ação, com apoio do Coordenador-Executivo de Ação ${ }^{513}$. O Gerente de Programa é o titular da unidade administrativa à qual o programa está vinculado e o Coordenador de Ação, da unidade administrativa à qual se vincula a ação ${ }^{514}$.

Compete ao Comitê de Gestão do PPA adotar medidas para fortalecer a gestão para resultados, orientando-se pelos princípios da eficiência, eficácia e da efetividade da ação

\footnotetext{
${ }^{508}$ SHEA, Robert. J. Performance Budgeting in the United States. OECD Journal on Budgeting. Volume 8, número 1, 2008, p. 62.

${ }^{509}$ OECD Journal on Budgeting. Special Issue. The Legal Framework for Budget Systems. An Internacional Comparison. Volume 4 - Número 3, 2004, p. 450.

${ }^{510}$ Art. $^{\circ}$ do Decreto $n^{\circ}$ 6.601/08 (dispõe sobre a gestão do PPA 2008-2011 e de seus programas).

511 SECRETARIA DE PLANEJAMENTO E INVESTIMENTOS ESTRATÉGICOS. Manual de Avaliação Plano Plurianual 2008/2011. Brasília, 2009, p. 07.

${ }^{512}$ Art. $2^{\circ}$, II, do Decreto $\mathrm{n}^{\mathrm{o}} 6.601 / 08$.

${ }^{513}$ Art. $2^{\circ}, \S 4^{\circ}$, do Decreto $n^{\circ} 6.601 / 08$.

${ }^{514}$ Art. $3^{\circ}, \S 2^{\circ}$, do Decreto $n^{\circ} 6.601 / 08$.
} 
governamental, e tendo como base os indicadores e metas do PPA, além de realizar o monitoramento estratégico do plano, com base na evolução dos indicadores e metas ${ }^{515}$.

Dentro do modelo de gestão do citado Plano, a avaliação anual tem como objetivo contribuir para a aferição dos resultados previstos nos programas e suas contribuições para o alcance dos objetivos setoriais e de Governo, assim como para o aperfeiçoamento contínuo da gestão de programas ${ }^{516}$.

De acordo com a concepção do modelo brasileiro,

a avaliação do PPA visa também ao fortalecimento da cultura do gerenciamento orientado para resultados na Administração Pública, na medida em que estimula a aprendizagem e a reflexão das equipes gerenciais a respeito do desempenho dos programas sob a ótica dos resultados, os quais devem ser medidos ${ }^{517}$.

A avaliação, portanto, fecha o ciclo das políticas públicas e programas (diagnóstico, formulação, implementação e avaliação), permitindo retroalimentar a discussão e elaboração dos programas, com vistas ao seu aperfeiçoamento.

\subsubsection{Conteúdo jurídico dos Programas Orçamentários}

A Constituição Federal de 1988 inscreve como conteúdo expresso do Plano Plurianual as diretrizes, objetivos e metas para as despesas de capital e outras delas decorrentes e para as relativas aos programas de duração continuada ${ }^{518}$.

No que se refere à Lei de Diretrizes Orçamentárias, o texto constitucional também explicita, como respectivo conteúdo integrante, as metas e prioridades da administração pública federal para o exercício financeiro subsequente ${ }^{519}$.

A seu turno, a Lei Orçamentária Anual deve ser compatível com o PPA ${ }^{520}$ e com a $\mathrm{LDO}^{521}$, e, dessa forma, os objetivos e metas, enquanto elementos básicos de estruturação das leis do PPA e LDO, devem orientar e condicionar a elaboração da LOA com vistas a assegurar a necessária compatibilidade e comunicabilidade aos instrumentos de planejamento e orçamento.

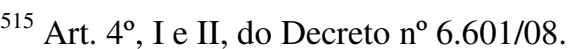

${ }^{516}$ SECRETARIA DE PLANEJAMENTO E INVESTIMENTOS ESTRATÉGICOS, op. cit., p. 06.

${ }^{517}$ Ibid., p. 08.

${ }^{518}$ Art. $165, \S 1^{\circ}, \mathrm{CF} / 88$.

${ }^{519}$ Art. $165, \S 2^{\circ}, \mathrm{CF} / 88$.

${ }^{520}$ Art. $165, \$ 7^{\circ}, \mathrm{CF} / 88$.

${ }^{521}$ Art. $166, \S 3^{\circ}, \mathrm{I}, \mathrm{CF} / 88$.
} 
A construção do desenho dos programas orçamentários é norteada pelos objetivos que se pretende alcançar com determinada intervenção estatal, e se encontra diretamente relacionada aos problemas sociais que se procura resolver. Nesse sentido, os programas são desmembrados em ações que procuram facultar o alcance dos objetivos pretendidos. Além disso, são atribuídos recursos financeiros que possibilitem o custeio das atividades necessárias ao razoável desempenho do programa.

Ao contrário da dotação orçamentária, que representa uma autorização de dispêndio, o objetivo de um determinado programa não consubstancia uma autorização direcionada ao administrador público. Os objetivos e metas inscritos nas leis orçamentárias representam, claramente, determinações exaradas à Administração, que deve envidar todos os esforços necessários à plena desincumbência das tarefas que lhe foram atribuídas. Nas palavras de Moncada:

O papel da lei relativamente à Administração deixa de ser apenas o de limite à respectiva actividade ou de autorização para tanto para passar a ser também o de incumbência administrativa ou seja, o de um projecto que compete à Administração optimizar mediante uma actividade verdadeiramente criativa ${ }^{522}$.

Em nosso ordenamento jurídico, a importância dos objetivos e metas consignados nas leis orçamentárias (PPA, LDO e LOA) é tamanha que houve por bem o legislador constituinte inscrevê-los como o conteúdo primeiro e fundante das peças orçamentárias. Portanto, o mais imediato caráter obrigatório que se depreende das leis orçamentárias é, exatamente, conferido pelos objetivos e metas expressamente inscritos nos instrumentos de planejamento e orçamento.

Os recursos financeiros representam os meios pelos quais se possibilitará o alcance dos objetivos traçados. Ou seja, existe uma nítida relação de função da dotação orçamentária, que somente existe em razão de um encargo ou atribuição conferida à Administração Pública. O caráter de obrigatoriedade dos fins pretendidos também é realçado por Jarach, nos termos seguintes:

Su significación se descubre a través de su conjunto; no hay una simple yuxtaposición de una serie de gastos y una nómina de recursos, sino un plan de erogaciones tendientes a lograr determinados fines con la indicación de los recursos correspondientes. De ahí su carácter obligatorio para todos los poderes públicos que deben cumplir com dicho plan. Esta obligatoriedad no excluye las economias, o sea la diferencia en menos de lo gastado en comparación com lo presupuestado, siempre que esa diferencia no implique

${ }^{522}$ MONCADA, Luís S. Cabral de. Direito público e eficácia. In: Estudos de Direito Público. Coimbra Editora, 2001, p. 193. 
un incumplimiento del plan econômico del sector público; tampoco excluye el exceso de recaudación de ciertos recursos por circunstancias contingentes, exceso que deberá compensarse con mermas em otros recursos, si las hubiere, o bien destinarse a los fines que el Parlamento establezca. ${ }^{523}$ (g.n.)

Portanto, muito mais do que apenas fixar um determinado emprego ou destino para os recursos financeiros atribuídos aos créditos orçamentários ${ }^{524}$, o Orçamento produz efeitos jurídicos no sentido de vincular toda a atividade governamental ao alcance dos objetivos e metas traçados; em outras palavras, há uma subordinação do emprego de tais recursos com vistas ao alcance de resultados previamente fixados. Nas palavras de Bandeira de Mello:

A ordenação normativa propõe uma série de finalidades a serem alcançadas, as quais se apresentam, para quaisquer agentes estatais, como obrigatórias. A busca destas finalidades tem o caráter de dever (antes do que "poder"), caracterizando uma função, em sentido jurídico ${ }^{525}$.

Nesse sentido, a análise da Lei de Orçamento não pode, sob hipótese alguma, prescindir da investigação de suas finalidades. Afinal, "é a finalidade da regra o que permite compreendê-la e que vai lhe dar o sentido que efetivamente tem",526.

Tais considerações não implicam em diminuição da importância das dotações orçamentárias. Ao contrário, a consignação de recursos financeiros dá a real medida da importância conferida a um determinado programa governamental pelo Legislativo. Ademais, sem os recursos financeiros não há como se garantir o alcance dos objetivos visados pelos programas orçamentários constantes da LOA.

Todavia, não há obrigatoriedade de execução dos recursos financeiros ou de exaurimento das dotações, que se encontram condicionadas e subordinadas aos objetivos que se pretende alcançar por meio do desenvolvimento dos programas.

Não por outro motivo, nosso ordenamento já previra que a fixação das cotas orçamentárias procuraria compatibilizar dois objetivos fundamentais: i) assegurar às unidades orçamentárias a soma de recursos necessários à melhor execução do programa

\footnotetext{
${ }^{523}$ JARACH, Dino. Finanzas Públicas y Derecho Tributario. Tercera edición - reimpresión. Buenos Aires: Abeledo-Perrot, 1996, p. 81/82.

${ }_{524}$ Sainz de Bujanda destaca que "respecto a los gastos públicos, el Presupuesto produce efectos jurídicos bien precisos en un triple sentido: autorizar a la Administración a realizar el gasto público; limitar las cantidades a gastar hasta un determinado montante y fijar el empleo o destino que haya de darse a los créditos aprobados en el Presupuesto". SAINZ DE BUJANDA, Fernando. Lecciones de Derecho Financiero. $7^{\mathrm{a}}$ ed. Madrid: Universidad Complutense, 1989, p. 432.

${ }^{525}$ BANDEIRA DE MELLO, Celso Antônio. Discricionariedade e Controle Jurisdicional. $2^{\mathrm{a}}$ ed., $7^{\mathrm{a}}$ tiragem. São Paulo: Malheiros, 2006, p. 13.

${ }^{526}$ Ibid., p. 45.
} 
anual de trabalho; e ii) manter, durante o exercício, dentro do possível, o equilíbrio entre a receita arrecadada e a despesa realizada ${ }^{527}$.

Eventualmente, o caso concreto pode indicar a necessidade de recursos adicionais para o alcance dos objetivos pretendidos, o que deverá ser viabilizado mediante a abertura de créditos suplementares, que visam ao reforço das dotações constantes de um determinado programa.

Nesse sentido, as adequações ou alterações orçamentárias devem, sempre, se realizar no interesse do alcance dos objetivos dos programas, de modo a permitir um melhor cumprimento de seus objetivos e metas.

Precisa definição das adequações ou alterações orçamentárias é encontrada no ordenamento mexicano: "Las adecuaciones presupuestarias se realizarán siempre que permitan un mejor cumplimiento de los objetivos de los programas a cargo de las dependencias y entidades" ${ }^{\text {,528 }}$. Tal definição é perfeitamente compatível com a sistemática orçamentária brasileira, muito embora não exista, entre nós, a conceituação normativa das alterações ou adequações orçamentárias.

Por outro lado, do exposto se extrai a inconstitucionalidade da atribuição de recursos notoriamente insuficientes ao cumprimento dos objetivos contemplados em determinado programa governamental. Destarte, pode-se afirmar que as chamadas janelas orçamentárias, como são conhecidos os programas aos quais são consignados irrisórios recursos financeiros, são inconstitucionais, visto que tais programas nascem viciados na origem, em virtude de notória impossibilidade de cumprimento dos fins a que se destinam.

Os objetivos e metas encontram-se indissociavelmente ligados aos resultados; afinal, aqueles são estabelecidos visando, justamente, a consecução destes últimos. $\mathrm{O}$ art. 74 do texto constitucional oferece relevantes parâmetros, transcritos a seguir:

Art. 74. Os Poderes Legislativo, Executivo e Judiciário manterão, de forma integrada, sistema de controle interno com a finalidade de:

I - avaliar o cumprimento das metas previstas no plano plurianual, a execução dos programas de governo e dos orçamentos da União;

II - comprovar a legalidade e avaliar os resultados, quanto à eficácia e eficiência, da gestão orçamentária, financeira e patrimonial nos órgãos e entidades da administração federal, bem como da aplicação de recursos públicos por entidades de direito privado; (grifos nossos)

Por conseguinte, a avaliação dos resultados dos programas e o alcance de metas e objetivos também encontram assento constitucional. Além de se constituírem em

\footnotetext{
527 Art. 48 da Lei $n^{\circ} 4.320 / 64$.

${ }^{528}$ Art. 58 da Ley Federal de Presupuesto y Responsabilidad Hacendaria Mexicana.
} 
obrigações atribuídas aos órgãos de controle interno, representam medidas ou parâmetros de análise que serão utilizados pelos órgãos de controle externo, no exercício de suas atribuições.

Mais do que isso, a necessidade de se avaliar resultados de programas e alcance de metas e objetivos das ações governamentais, bem como a fiscalização desta atividade, pelos órgãos de controle, tornam explícita a obrigatoriedade de perseguição dos objetivos pretendidos pela ação do Governo.

Em vista disso, os Tribunais de Contas, no exercício da fiscalização orçamentária, tem o poder-dever de alertar os Poderes e órgãos autônomos quando forem constatados fatos que comprometam os resultados dos programas ${ }^{529}$, além de possuir competência para julgar as contas dos administradores e demais responsáveis pelos recursos públicos ${ }^{530}$, no que se inclui a gestão orçamentária e financeira dos órgãos, bem como para aplicar penalidades no caso de ilegalidade das despesas ${ }^{531}$.

A definição de objetivos e a implementação da gestão por resultados estão diretamente associados. Como destaca Allen Schick: "Por el lado del desempeño, los gobiernos que tienen una óptica de gestión imponen generalmente especificar ex ante los objetivos de desempeño y medir los resultados efectivos en comparación con los objetivos fijados" ${ }^{, 532}$.

A sistemática orçamentária constitucional brasileira encontra-se impregnada dos valores e elementos constantes do modelo orçamentário conhecido como Orçamento de Desempenho - performance-based budget -. Definem-se objetivos e metas, associando-se recursos financeiros, indicadores de desempenho e custos das respectivas ações e programas.

Como assegura José Afonso da Silva, o Orçamento de Desempenho é "aquele que oferece os fins e os objetivos para os quais se requerem os fundos públicos, os custos das atividades propostas para alcançar esses fins e os dados quantitativos que medem as realizações e as tarefas executadas dentro de cada uma dessas atividades",533.

\footnotetext{
${ }^{529}$ Art. 59, $\S 1^{\circ}, \mathrm{V}, \mathrm{LRF}$.

${ }_{530}$ Art. $70, \mathrm{II}, \mathrm{CF} / 88$.

531 Art. 70, VIII, CF/88.

532 SCHICK, Allen. La presupuestación tiene algún futuro? Serie Gestión Pública no 21. Traducción de Varinia Tromben y revisión final de Ricardo Martner. Naciones Unidas. Instituto Latinoamericano y del Caribe de Planificación Económica y Social (ILPES): Chile, maio/2002, p. 42.

${ }^{533}$ SILVA, José Afonso da. Orçamento-Programa no Brasil. São Paulo: Editora Revista dos Tribunais, 1973, p. 19 .
} 
Diante disso, pode-se afirmar que a Constituição Federal de 1988 encampou, de forma implícita, a concepção de Orçamento de Desempenho, realçando as elevadas funções que competem ao gerenciamento orçamentário em nosso país. Portanto, há que haver uma gestão do Orçamento que privilegie um planejamento moderno, com fixação de objetivos e metas factíveis, dotações orçamentárias realistas, seleção criteriosa dos indicadores de desempenho, elaboração cuidadosa do desenho do programa governamental e respectivas ações, bem como da fixação dos produtos e metas físicas de modo a se possibilitar a aferição imediata dos resultados obtidos com os recursos assinalados.

Interessante salientar que a teoria clássica do Orçamento, que tem em Laband e Jèze dois de seus mais ilustres representantes, não trabalha com a categoria programática e, tampouco, revela interesse pelos fins ou objetivos contemplados na Lei de Orçamento. E tal fato ocorre justamente porque, nos albores da criação dos institutos orçamentários, não se vislumbrava o imenso caminho que seria percorrido pela peça orçamentária.

No século XIX, o Orçamento público encontrava-se absolutamente vinculado a um modelo de organização de tabelas de gastos, discriminando-se, tão-somente, recursos e objetos de gastos. Ou seja, naquela época a expressão mais avançada de Orçamento era, justamente, aquela que possibilitava a visualização dos elementos de gastos que seriam adquiridos com os recursos atribuídos. Conforme Silva:

O orçamento tradicional limitava-se, fundamentalmente, a uma relação das receitas e fixação das despesas. Era um ato de previsão e autorização das receitas e das despesas. Seu objetivo básico, historicamente, foi sempre o de assegurar o controle político das atividades governamentais; controle que se fazia através dos órgãos legislativos sobre as atividades financeiras dos órgãos do Executivo. Era um orçamento político, contábil e financeiro apenas. Não tinha outra pretensão, não visava outra finalidade ${ }^{534}$.

De acordo com aquela concepção tradicional de Orçamento, a alocação de recursos visava à aquisição de meios, com ênfase em aspectos contábeis, além de utilizar como principais critérios classificatórios as unidades administrativas e os elementos ${ }^{535}$. Em contraposição, modernamente, de acordo com as concepções atuais do Orçamento, $a$ alocação de recursos tem por objetivo principal a consecução de objetivos e metas, utilizando-se de critérios classificatórios mais modernos, a exemplo da funcionalprogramática. Portanto, não é de se admirar que a doutrina clássica enfatizasse categorias e elementos dos Orçamentos tradicionais.

\footnotetext{
${ }^{534}$ SILVA, José Afonso da. Orçamento-Programa no Brasil. São Paulo: Editora Revista dos Tribunais, 1973, p. 40.

${ }^{535}$ GIACOMONI, James. Orçamento Público. 14ª ed. São Paulo: Atlas, 2007, p. 166.
} 
Assentado que os objetivos e metas representam a primeira e mais imediata obrigatoriedade constante da Lei de Orçamento, há que se fazer alguma análise acerca do alcance dos resultados. Afinal, se os fins constantes da Lei de Orçamento apresentam-se como obrigatórios, há que se indagar como se fará a aferição de seu cumprimento.

Em primeiro lugar, cumpre destacar a fragilidade da tentativa de estabelecimento de uma relação direta de causalidade entre o desenvolvimento de um programa e o resultado esperado. Efetivamente, há um sem-número de circunstâncias que influenciam e modificam os parâmetros sociais. Tais fatores podem implicar em alterações, positivas ou negativas, nos indicadores utilizados para a mensuração dos resultados e, em muitos casos, não decorrem do desenvolvimento das atividades relacionadas ao programa.

Nas palavras de Allen Schick:

Hemos asistido a una explosión de la literatura respecto de la medición de resultados,
pero la dificultad de aplicar los resultados a las decisiones presupuestarias está bien
establecida. Los resultados escapan habitualmente al control directo del ministerio que
ejecuta el programa y resultan generalmente de una convergencia de factores y no
simplemente de la intervención del gobierno dentro de la política. Nos podemos
preguntar si se puede establecer una relación de causalidad entre los cambios que se
producen al nivel de las políticas y la situación social.
(...) En mi opinión, es más productivo pensar los resultados como señales direccionales
y no como afirmaciones de causalidad. Los resultados deben empujar a los gobiernos a
evaluar si la situación social va en la dirección deseada y si cambios de política debe ser
o no considerados. ${ }^{36}$

De acordo com essa visão, os resultados deveriam ser considerados como nortes ou indicações de sentido e direção e não como afirmações de causalidade.

Entre nós, Jannuzzi também aponta a dificuldade de se atribuírem os efeitos de programas específicos sobre as mudanças estruturais das condições sociais ${ }^{537}$. obstáculo ainda é maior quando existe problema de descontinuidade na execução e implementação de programas públicos. Acrescente-se a tais questões, a complexidade da sociedade brasileira e os diversos efeitos que podem ser obtidos por programas em diferentes regiões:

Determinados programas implementados em regiões mais pobres poderão não ter resultados tão promissores como em outras mais desenvolvidas. Assim, é preciso avaliar a eficiência dos programas em função não apenas em relação ao resultado obtido e à quantidade de recursos alocados, mas considerando as dificuldades ou potencialidades existentes na região em que os programas estão funcionando ${ }^{538}$.

\footnotetext{
${ }^{536}$ SCHICK, Allen, op. cit., p. 26/27.

${ }^{537}$ JANNUZZI, Paulo de Martino, op. cit., p. 156.

538 Ibid., p. 155.
} 
Reconhecida a fragilidade da visão dos resultados enquanto afirmações de causalidade, há que se buscar outro elemento que permita uma concreta e imediata visualização dos resultados obtidos pelo desenvolvimento dos programas, de forma a se poder aferir o devido cumprimento dos fins da Lei de Orçamento.

Como visto, os programas encontram-se, na estrutura orçamentária federal, desdobrados em ações, das quais resultam produtos (bens ou serviços), que contribuem para atender ao objetivo de um programa.

Os produtos representam o resultado mais concreto que se obtém na execução de um certo programa governamental. Constam devidamente mensurados em termos de meta física - quantidade de produto a ser ofertada por ação, de forma regionalizada, para o período de um ano -. Por último, as metas físicas devem ser estabelecidas guardando relação com a quantidade de recursos financeiros atribuídos.

Destarte, os produtos, enquanto resultados mais diretos e imediatos da intervenção estatal, representam o elemento da Lei de Orçamento que, de forma mais direta, faculta a aferição do devido cumprimento da peça orçamentária.

Tais considerações terminam por nos remeter à tradicional diferenciação entre resultados - outcomes - e produtos - outputs -. Enquanto que os resultados orientam e norteiam o desenvolvimento dos programas orçamentários e das políticas públicas, os produtos são o resultado concreto e imediato da consecução dos esforços na busca do alcance dos objetivos e metas traçados. Na lição de Allen Schick:

The basic idea (of performance) is that government should deliver efficient services and operate efficient programmes. In the burgeoning literature on performance, efficiency generally is associated with outputs - the goods and services produced by government and effectiveness with outcomes - the impacts of government programmes on society. Efficiency has both quantitative and qualitative characteristics that include the volume and cost of services, response times and error rates, the accessibility of services and the courtesy with which they are provided, and citizen/ customer satisfaction with services. Effectiveness means that programmes are in accord with the priorities and objectives of government, and produce the expected or desired impacts.

It is widely accepted that outcomes are the most important dimension of performance, but it is also recognised that outcome data are often unavailable or costly to obtain, and that even when data are available, the causal relationship between government policy and social conditions may be problematic. In countries that take performance seriously, reforms that aim to improve outcomes tend to end up focusing on outputs instead. This 'second best' situation certainly is more productive than spending years in the quest for ideal outcome measures. Outputs are a useful indicator of performance because citizens know government by observing the condition of school classrooms and the number of students per class, the distance from home to health clinic and the waiting time once they get there, the treatment given by police officers, and the countless other contacts 
that ordinary citizens have with government agencies and public employees. Outputs are the face presented by government to its people ${ }^{539}$.

José Afonso da Silva, ao tratar das finalidades da estruturação programática nos orçamentos, também indica que os resultados, de forma mais imediata, podem ser mensurados pelas unidades físicas produzidas em decorrência da atividade governamental. Em suas palavras: "a classificação por programas tornou-se verdadeiro princípio orçamentário moderno. Seu objetivo é vincular as despesas aos resultados, expressos em unidades físicas que se espera alcançar ${ }^{\prime 540}$.

É também José Afonso da Silva que salienta a importância do produto final output -:

O objetivo do programa se traduz concretamente em termos de produto final, isto é, coordena-se o emprego de insumos (inputs) para conseguir-se o produto final (output), assim considerado cada tipo de bem ou serviço que satisfaça, por si só, certas necessidades, efetuando-se pelo atendimento destas através da produção de bens ou da prestação de serviços, como, por exemplo, estradas construídas, adultos alfabetizados, crianças vacinadas, número de merendas escolares distribuídas, prédios escolares, fóruns, cadeias construídas, etc ${ }^{541}$.

Em vista disso, pode-se afirmar que, enquanto que os resultados - outcomes devem nortear a ação pública, os produtos - outputs - terminam por se consubstanciar no imediato e concreto resultado decorrente das atividades programáticas. Os dois vinculam a ação pública, todavia, somente os últimos - produtos - podem ser exigidos de forma concreta e, dessa forma, consubstanciam o termômetro mais exato do cumprimento da Lei de Orçamento.

Em síntese, os objetivos e metas da Lei de Orçamento são obrigatórios, vinculando a Administração Pública à sua perseguição e alcance. Para a necessária mensuração dos resultados apresentados pelo Governo à frente da execução dos programas e do grau de cumprimento dos objetivos e metas, há que se considerar os resultados visados, enquanto indicações do caminho a ser percorrido, e, de forma mais imediata e concreta, os produtos e metas físicas obtidos na execução orçamentária.

Os produtos ou metas físicas representam o mais imediato e factível indício do cumprimento dos deveres revelados pela Lei de Orçamento. Para que seja possível a

\footnotetext{
539 SCHICK, Allen. The Performing State: Reflection on an Idea Whose Time Has Come but Whose Implementation has not. OECD Journal on Budgeting. V. 3, n. 2, 2003, p. 73/74.

${ }^{540}$ SILVA, José Afonso da. Orçamento-Programa no Brasil. São Paulo: Editora Revista dos Tribunais, 1973, p. 63.

${ }^{541}$ Ibid., p. 113/116.
} 
produção de bens ou serviços durante a atividade produtiva relacionada à execução do Orçamento, são consignados recursos orçamentários para o desenvolvimento das referidas atividades. Dada a fragilidade da relação causal entre programa e resultado, é necessário considerar, de maneira mais concreta, a produção resultante da atividade governamental desenvolvida à frente da execução de certo programa.

Nesse sentido, enquanto os resultados continuam orientando a atuação governamental, no longo prazo, as metas físicas ou produtos resultantes da execução orçamentária darão a medida ou grau do cumprimento dos fins desejados pelo Legislador, quando consignou determinado montante de recursos orçamentários para a execução de certo programa.

Tome-se como exemplo, o Programa Energia Alternativa Renovável, desenvolvido no âmbito do Ministério das Minas e Energia ${ }^{542}$, que se encontra previsto no Orçamento Fiscal na seguinte conformidade:

\section{Programa 1044 - Energia Alternativa Renovável}

\begin{tabular}{|l|l|r|}
\hline 1044 & Energia Alternativa Renovável & Valor \\
\hline & 8122 - Valorização Energética de Resíduos Sólidos Urbanos & 10.379 .308 \\
\hline & - Estudo realizado (unidade): 23 & \\
\hline & 7050 - Implantação de Plantas Demonstrativas de Fontes de Energia \\
& Alternativa Renovável & \\
\hline & - Projeto-piloto implantado (unidade): 3 & \\
\hline
\end{tabular}

O objetivo do programa é o seguinte: "Ampliar a oferta de energia por meio de fontes renováveis, em base auto-sustentável, minimizando os impactos ambientais" ${ }^{\text {"543 }}$. Seu público-alvo são as concessionárias, permissionárias, agentes produtivos e consumidores de energia elétrica, ao passo que o indicador selecionado é a taxa de participação de energias renováveis na matriz elétrica (\%).

No caso da atividade de valorização energética de resíduos sólidos urbanos, o produto é representado pelo estudo realizado, sendo sua meta física a elaboração de 23 estudos. Visando o alcance da referida meta, foi consignada a dotação no valor de $\mathrm{R} \$ 10.379 .308,00$.

542 Lei $\mathrm{n}^{\text {o }} 11.897 / 08$ (LOA de 2009), Volume IV, p. 217. Disponível em [https://www.portalsof.planejamento.gov.br/sof/2009/VOL_IV.pdf]. Acesso em 28.09.2009.

${ }^{543}$ Lei no 11.653/08 (PPA 2008-2011), Anexo I - Programas de Governo Finalísticos, p. 272. Disponível em [http://www.planejamento.gov.br/secretarias/upload/Arquivos/spi/plano_plurianual/PPA/081015_PPA_2008 _Anexo1.pdf]. Acesso em 30.09.2009. 
Por sua vez, o projeto de implantação de plantas demonstrativas de fontes de energia alternativa renovável possui como produto o projeto-piloto implantado. A meta física desta ação é de construção de três unidades de projetos-piloto implantados, para o que se previu a alocação de recursos no valor de $\mathrm{R} \$ 740.000,00$.

Nesse caso, tem-se que o resultado mais imediato - e passível de aferição - do cumprimento da Lei de Orçamento é, justamente, o alcance das metas físicas projetadas para as respectivas ações. Apesar disso, o objetivo continua norteando a condução do programa e a atuação da máquina estatal no desenvolvimento das atividades necessárias à plena desincumbência das tarefas que lhe foram atribuídas.

\title{
4.6 Conflitos entre objetivos fiscais e programáticos
}

Visto que os objetivos e metas fiscais e os objetivos e metas dos programas orçamentários enfeixam o caráter de obrigatoriedade, vinculando o administrador público ao seu alcance, cabe traçar algumas considerações acerca da possibilidade de conflito entre os objetivos e metas, bem como das balizas oferecidas pelo ordenamento brasileiro, nesse tocante.

Moncada destaca que, frequentemente, os objetivos perseguidos apresentam certa incompatibilidade e, nesse sentido, o alcance de alguns termina por prejudicar o alcance de outros. Em suas palavras:

\begin{abstract}
A complexidade da decisão administrativa decorre não apenas da sua relativa indemonstrabilidade, como se viu, mas ainda da respectiva natureza finalística: a aç̧ão administrativa é orientada para fins que frequentemente se apresentam como relativamente incompatíveis, pelo que a efectiva consecução de algum ou alguns deles prejudica inexoravelmente os outros ${ }^{544}$.
\end{abstract}

A problemática da perseguição simultânea a vários objetivos pelas organizações levou à elaboração de uma teoria que considera a existência de distintos níveis de objetivos, igualmente da existência de uma hierarquia entre os mesmos, de forma que os objetivos mais amplos ou estratégicos predominariam sobre objetivos setoriais e departamentais:

${ }^{544}$ MONCADA, Luís S. Cabral de. Direito público e eficácia. In: Estudos de Direito Público. [S.1.]: Coimbra Editora, 2001, p. 195. 
As organizações buscam alcançar vários objetivos simultaneamente. Assim, há uma hierarquia de objetivos na qual alguns deles são mais importantes e predominam sobre os demais. Existem objetivos da empresa como um todo, de cada uma de suas divisões ou departamentos e de cada cargo ou tarefa. Os objetivos da empresa predominam sobre todos os demais objetivos, enquanto os objetivos de cada divisão predominam sobre os objetivos de cada tarefa. Os objetivos maiores impõem-se aos objetivos específicos ${ }^{545}$.

Para Burkhead, tais considerações são críticas quando se trata do sistema orçamentário, em que, tradicionalmente, existe um potencial conflito entre o órgão central de orçamento e as unidades setoriais de orçamento. Nesse caso, torna-se vital estabelecer quando e em que medida devem as decisões do órgão central prevalecer sobre as decisões setoriais:

Este é um problema crítico: até que ponto deve-se permitir às considerações centrais ou de âmbito mais amplo do Governo, que superem e dominem aquelas relativas a departamentos ou programas. Há considerações que são centrais em sua natureza e deveriam conduzir a decisões centralizadas, e há outras considerações e respectivas decisões que podem perfeitamente ser descentralizadas ${ }^{546}$.

Concebida a existência de uma hierarquia de objetivos, em que algumas espécies de objetivos devem prevalecer sobre outras, surge, como decorrência, os desdobramentos dos objetivos, por meio do que são alinhadas estratégias e táticas para o alcance dos objetivos centrais. Nas palavras de Chiavenato:

Em decorrência da hierarquia de objetivos surgem os desdobramentos dos objetivos. A partir dos objetivos organizacionais, a empresa pode fixar suas políticas, diretrizes, metas, programas, procedimentos, métodos e normas. Enquanto os objetivos organizacionais são amplos e genéricos, à medida que se desce em seus desdobramentos, a focalização torna-se cada vez mais restrita e detalhada. (...)

Os objetivos maiores possuem uma amplitude maior e um menor detalhamento; por sua vez, os objetivos específicos caracterizam-se por uma menor amplitude e por um maior detalhamento.

Existem três níveis distintos de planejamento: estratégico, tático e operacional. O planejamento estratégico é mais amplo e abrange toda a organização, além de ser projetado no longo prazo, com efeitos e conseqüências estendidos por vários anos pela frente. Sua definição é realizada pela cúpula da organização em seu nível institucional.

Por sua vez, o planejamento tático abrange cada departamento ou unidade da organização; é projetado para o médio prazo e definido no nível intermediário da organização.

A seu turno, o planejamento operacional abrange cada tarefa ou atividade específica, sendo projetado para o curto prazo e definido no nível operacional, para cada tarefa ou atividade $^{547}$.

\footnotetext{
${ }^{545}$ CHIAVENATO, Idalberto. Introdução à Teoria Geral da Administração. $7^{\mathrm{a}}$ ed. Rio de Janeiro: Elsevier, 2003, p. 169.

${ }^{546}$ BURKHEAD, Jesse. Orçamento Público. Rio de Janeiro: Fundação Getúlio Vargas, 1971, p. 446.

${ }^{547}$ CHIAVENATO, Idalberto, op. cit., p. 169/171.
} 
Feitas essas considerações introdutórias, há que se relembrar que as três leis orçamentárias, em nosso ordenamento, devem se apresentar articulada e coordenadamente integradas, de modo a viabilizar a compatibilidade exigida pelo texto constitucional $^{548}$.

A Carta de 1988 determina que leis de iniciativa do Poder Executivo deverão estabelecer: i) o plano plurianual; ii) as diretrizes orçamentárias; e iii) os orçamentos anuais $^{549}$. No ordenamento brasileiro, os três instrumentos são fixados por meio de leis ordinárias, portanto, estatutos legais de idêntica hierarquia normativa. Todavia, se formalmente os três instrumentos são diplomas ordinários, a doutrina aponta para a existência de certa vinculação entre PPA, LDO e LOA.

No ordenamento jurídico português, a relação entre a lei de plano e o orçamento deu lugar a relevantes desenvolvimentos doutrinários. Nesse aspecto, confira-se a lição de Canotilho:

A consideração da lei do orçamento como lei vinculada pode e deve ser articulada com a moderna problemática das leis reforçadas, designadamente com as leis do plano. (...) existência de certas leis ordinárias que impõem ou pressupõem a sua não derrogabilidade por leis ordinárias posteriores. Neste caso, algumas leis ordinárias consideram-se a si próprias como leis supraordenadas em relação a outras leis posteriores, tendo como efeito jurídico mais significativo a inversão da regra da eficácia derrogatória da lei posterior ${ }^{550}$.

Moncada também teceu valiosas considerações acerca dessa relação:

Sucede que um dos processos de reforçar a eficácia jurídica do plano é o de o relacionar com o orçamento (...). É este processo de interpenetração do orçamento e do plano que vem colocar em termos novos a problemática jurídica do orçamento e, reciprocamente, do plano ${ }^{551}$.

É ainda Cabral de Moncada que expõe considerações associando a questão da existência de hierarquia entre diferentes objetivos visados pelo Poder Público com a da relação existente entre as diferentes leis orçamentárias. Em suas palavras:

$\mathrm{Na}$ verdade se o planeamento pretende servir de guia racional e eficaz para as despesas públicas que prevê, norteadas estas além do mais pelos propósitos normativos que assume, terá sempre de privilegiar certos objectivos de interesse geral em relação a

${ }^{548}$ Art. $165, \S 7^{\circ}, \mathrm{CF} / 88$; Art. $166, \S 3^{\circ}, \mathrm{I}, \mathrm{CF} / 88$ e Art. $166, \S 4^{\circ}, \mathrm{CF} / 88$.

${ }^{549}$ Art. 165, I, II e III, CF/88.

${ }^{550}$ CANOTILHO, José Joaquim Gomes. A Lei do Orçamento. In: Estudos em Homenagem ao Prof. Doutor J. J. Teixeira Ribeiro. Universidade de Coimbra: Boletim da Faculdade de Direito, Número Especial, 1979, p. 558.

551 MONCADA, Luís S. Cabral de. Perspectivas do Novo Direito Orçamental Português. In: Estudos de Direito Público. [S.1.]: Coimbra Editora, 2001, p. 55. 
outros de modo a poder estabelecer uma hierarquia entre eles. O processo seguido para comparar os objectivos de política económica e a sua oportunidade face às circunstâncias é decompô-los em unidades concretas de acções concertadas denominadas programas ou projectos de despesas públicas ${ }^{552}$.

Embora sejam estatutos ordinários, no ordenamento brasileiro, as três leis orçamentárias somente podem ser modificadas por leis específicas, elaboradas com o objetivo único de introduzir alterações em seus dispositivos. Isso ocorre com a lei do PPA e suas alterações, com a LDO e suas alterações, bem como com a LOA e as alterações que se fizerem necessárias.

No sistema orçamentário português, contudo, modificações havidas naquele ordenamento $^{553}$ possibilitaram a defesa da atenuação da rigidez hierárquica outrora existente entre a Lei de Plano e a Lei de Orçamento. Na afirmação de Moncada:

A atenuação da rigidez da hierarquia referida é também aconselhada pela ciência económica. Não faria sentido num sistema econômico caracterizado pela preponderância, apesar de tudo, dos mecanismos de mercado como é o português, que o planeamento fosse visto como um documento infalível e inalterável, insusceptível de adaptação às circunstâncias sempre em mudança ${ }^{554}$.

No caso do Brasil, a compatibilidade existente entre PPA, LDO e LOA indica a necessidade de que objetivos estratégicos traçados na lei do PPA sejam observados na elaboração das diretrizes e metas da LDO, as quais, por sua vez, devem ser consideradoa na discussão, votação, elaboração e execução da Lei de Orçamento.

Nesse sentido, os objetivos estratégicos devem encontrar, no Plano Plurianual, seu campo adequado e propício de florescimento; na Lei de Diretrizes Orçamentárias, por sua vez, devem se consubstanciar, por excelência, a fixação dos objetivos e metas fiscais; por último, na Lei de Orçamento cabe a elaboração e fixação dos objetivos operacionais, ou, em outras palavras, dos objetivos programáticos, que buscam dar concretude aos objetivos fiscais e estratégicos definidos no PPA e na LDO.

${ }^{552}$ MONCADA, Luís S. Cabral de. Perspectivas do Novo Direito Orçamental Português. In: Estudos de Direito Público. Coimbra Editora, 2001, p. 59.

553 Como destaca Moncada: "A proposta governamental de lei do orçamento pode conter projectos de alteração da lei do plano. (...) deste modo a subordinação do orçamento à lei do plano é muito mais tênue do que parece à primeira vista, porque a lei do orçamento a pode alterar (ou derrogar) e por proposta do Governo. A lei do plano não vincula a iniciativa legislativa quer do Parlamento quer do Governo. A atenuação da rigidez da relação de subordinação que se referiu fica a dever-se, de outro ponto de vista, ao facto de a lei do plano não ter uma força jurídica superior à da lei ordinária, não constituindo um terceiro gênero intermediário entre a Constituição e a lei, pelo que está sempre a tempo de ser alterada, derrogada ou revogada por outra lei ordinária, desde logo pela lei orçamental”. MONCADA, Luís S. Cabral de, op. cit., p. $81 / 82$.

${ }^{554}$ MONCADA, Luís S. Cabral de. Perspectivas do Novo Direito Orçamental Português. In: Estudos de Direito Público. [S.1.]: Coimbra Editora, 2001, p. 83. 
Somente a elaboração coordenada e articulada dos objetivos mais genéricos - Plano Plurianual - até os mais concretos - Lei de Orçamento - pode dar concretude à vinculação da atuação governamental, relativamente aos instrumentais de planejamento e orçamento.

Portanto, há uma hierarquia entre os objetivos estratégicos, objetivos fiscais e objetivos programáticos, de forma que, havendo conflito entre os objetivos mais concretos e aqueles estratégicos ou fiscais, os programáticos devem ceder lugar à observância dos estratégicos e/ou dos fiscais, dentro de critérios de razoabilidade, logicamente.

O conflito potencial mais evidente é aquele decorrente da insuficiência de recursos financeiros para o financiamento de todos os programas e ações desenvolvidas pelos Ministérios e órgãos da Administração Pública Federal ${ }^{555}$. Assim sendo, em muitas ocasiões o alcance dos objetivos fiscais é privilegiado em relação a objetivos programáticos, prejudicando o alcance dos objetivos fixados nos programas governamentais.

Nosso ordenamento deixa expressamente consignado que a fixação das cotas orçamentárias procura compatibilizar dois objetivos fundamentais: i) assegurar às unidades orçamentárias a soma de recursos necessários à melhor execução do programa anual de trabalho; e ii) manter, durante o exercício, dentro do possível, o equilíbrio entre a receita arrecadada e a despesa realizada ${ }^{556}$. No mesmo sentido, as propostas parciais de orçamento deverão guardar conformidade com a política econômico-financeira do Governo $^{557}$.

Juridicamente, pode-se dizer que esse ordenamento encontra-se devidamente coordenado. Há metas fiscais a serem alcançadas, assim como são atribuídos recursos orçamentários para os programas definidos como prioritários pelo Governo. As metas fiscais e um regime de responsabilidade fiscal não são incompatíveis, a priori, com a devida e razoável atribuição de recursos para as unidades orçamentárias executarem seus programas de trabalho.

O caso mais recorrente tem sido o de conflitos entre objetivos fiscais e objetivos programáticos, ou seja, de conflitos verticais - conflitos entre objetivos previstos na lei de

\footnotetext{
${ }^{555}$ As despesas para os programas governamentais são sempre limitadas. Desta forma, "Todo órgão central de orçamento, portanto, sente que deve economizar e fazer cortes nos pedidos para programas. (...) Essa pressão no sentido de fazer cortes na despesa constitui meio de estimular o aperfeiçoamento administrativo. O órgão central de orçamento, com sua revisão, sempre aconselha os órgãos e departamentos a realizarem o mesmo programa com menos recursos, pressupondo que um contínuo esforço no sentido de poupar resultará em operações mais eficientes". BURKHEAD, Jesse. Orçamento Público. Rio de Janeiro: Fundação Getúlio Vargas, 1971, p. 371.

${ }^{556}$ Art. 48 da Lei ${ }^{\circ} 4.320 / 64$.

${ }^{557}$ Art. 27 da Lei no ${ }^{\circ} .320 / 64$.
} 
diretrizes orçamentárias com os objetivos programáticos estabelecidos nas leis orçamentárias anuais -. Nesse caso, tem sido tradicionalmente conferida certa primazia aos objetivos fiscais, que terminam por condicionar a execução orçamentária.

Para Fernando Abrucio, tais lógicas aparecem como antagônicas:

$\mathrm{Na}$ atual era de escassez de recursos por que passa o Estado, duas lógicas antagônicas aparecem como alternativas. Uma é a fiscal, preocupada em controlar os inputs do sistema para evitar o aumento dos custos. Outra é a gerencial, que busca aumentar a eficiência e a efetividade, de tal forma que sua lógica se baseia em atingir os objetivos, ou seja, obter melhores outputs ${ }^{558}$.

Em nosso entender, desde a elaboração da lei orçamentária, deve-se buscar a compatibilização de objetivos fiscais e programáticos. Ambas espécies de objetivos integram validamente o corpo da peça orçamentária, de modo que as lógicas subjacentes a cada espécie não são necessariamente conflitantes, embora assim possam se revelar em determinadas circunstâncias.

Contudo, eventualmente pode ocorrer certa incompatibilidade entre a necessidade de dotações das unidades orçamentárias e o atingimento das metas fiscais. Nesse caso, recorre-se, provisoriamente, às limitações de empenho e movimentação financeira, na forma prevista pela legislação. Restabelecidas as metas de arrecadação e superadas eventuais quedas de arrecadação, há que se proceder à recomposição das dotações, conforme dispõe o art. $9^{\circ}$ da LRF:

Art. 9ำ Se verificado, ao final de um bimestre, que a realização da receita poderá não comportar o cumprimento das metas de resultado primário ou nominal estabelecidas no Anexo de Metas Fiscais, os Poderes e o Ministério Público promoverão, por ato próprio e nos montantes necessários, nos trinta dias subseqüentes, limitação de empenho e movimentação financeira, segundo os critérios fixados pela lei de diretrizes orçamentárias.

$\S 1^{\circ}$ No caso de restabelecimento da receita prevista, ainda que parcial, a recomposição das dotações cujos empenhos foram limitados dar-se-á de forma proporcional às reduções efetivadas.

$\S 2^{\underline{0}}$ Não serão objeto de limitação as despesas que constituam obrigações constitucionais e legais do ente, inclusive aquelas destinadas ao pagamento do serviço da dívida, e as ressalvadas pela lei de diretrizes orçamentárias.

Registre-se que, em nosso ordenamento, em face da existência de despesas constitucionais e/ou legais obrigatórias, prevê-se, como se extrai da leitura do $\S 2^{\circ}$ do art.

\footnotetext{
558 ABRUCIO, Fernando Luiz. Os avanços e os dilemas do modelo pós-burocrático: a reforma da administração pública à luz da experiência internacional recente. In Reforma do Estado e Administração Pública Gerencial. BRESSER PEREIRA, Luiz Carlos; SPINK, Peter. (orgs.). $6^{\mathrm{a}}$ ed. Rio de Janeiro: Editora FGV, 2005, p. 194.
} 
$9^{\circ}$ da LRF, que sejam tais despesas excluídas da necessidade de limitação de empenho. Em vista disso, nosso ordenamento protege as dotações relativas a tais despesas, em razão da existência de outros comandos legais e constitucionais que incidem sobre tais gastos.

Além do mais, também é relevante destacar, nesse contexto, que a seleção das ações e programas prejudicados pela limitação de empenho e movimentação financeira é deixada aos órgãos e unidades orçamentárias responsáveis pela execução do programa de trabalho, visto que são exatamente estes que podem avaliar, em face do caso concreto, quais programas e ações devem ser priorizados e quais devem suportar a limitação provisória de sua execução:

\begin{abstract}
Nos instrumentos de limitação dos gastos do Governo Federal não são indicados especificamente os programas ou itens de despesa que deverão deixar de ser executados. Cada órgão mantém inteira flexibilidade para, ressalvadas as despesas obrigatórias e outras especificamente definidas, realizar suas próprias avaliações e priorizar os seus gastos, escolhendo, dentre as diversas despesas discricionárias que compõem o valor global autorizado na LOA, aquelas que julgar prioritárias, até o limite de gasto fixado $^{559}$.
\end{abstract}

Nesse sentido, há espaço para certa discricionariedade do administrador público, diante da necessidade de seleção dos programas e objetivos a serem privilegiados, visto que existirá certa concorrência - neste caso horizontal - entre programas e objetivos programáticos de diferentes espécies e categorias.

Nesse caso, deve-se levar em conta que os programas não se encontram todos no mesmo nível de desenvolvimento. Há uns mais adiantados do que outros, enquanto que podem existir problemas ou circunstâncias momentâneas que impeçam, durante certo período, a execução de um certo programa. Dessa forma, os programas podem competir por recursos orçamentários: para alguns haverá necessidade de suplementação das dotações orçamentárias, que lhe possibilite um maior e mais amplo desenvolvimento; para outros, ao contrário, e por determinados períodos, não existirá óbice a que parte dos recursos orçamentários que lhe foram consignados sejam transferidos. Há uma multiplicidade de circunstâncias que podem exigir a modificação da composição das dotações constante da Lei de Orçamento tal como aprovada.

Eventual conflito vertical entre objetivos fiscais e programáticos termina acarretando um conflito horizontal - no nível dos programas - visto que diversos programas governamentais disputam os recursos escassos disponíveis na sociedade. Dessa

559 ALBUQUERQUE, Claudiano; MEDEIROS, Márcio; FEIJÓ, Paulo Henrique. Gestão de Finanças Públicas. 2a ed. Brasília: Editor Paulo Henrique Feijó da Silva, 2008, p. 545. 
forma, alguns deverão sofrer contingenciamento, enquanto que outros deverão ser privilegiados, mantendo-se suas dotações, tais quais aprovadas pelo Legislativo.

$\mathrm{O}$ reconhecimento da discricionariedade associada às necessidades de priorização de ações, não implica em atribuição de amplos e livres poderes de seleção, pelo administrador público, em dissonância com o objetivo visado pela lei. Contudo, somente a análise concreta do andamento dos diversos programas, das diferentes necessidades financeiras dos programas e das diferentes repercussões na execução dos programas, pode facultar uma tomada de decisão criteriosa.

Nesse caso, cabem, com precisão, as palavras de Bandeira de Mello:

o administrador está, então, nos casos de discricionariedade, perante o dever jurídico de praticar, não qualquer ato dentre os comportados pela regra, mas, única $e$ exclusivamente aquele que atenda com absoluta perfeição à finalidade da lei ${ }^{560}$.

E, no mesmo sentido, a seguinte lição:

\begin{abstract}
Uma vez que atividade administrativa é desempenho de função e dado que função é o cumprimento obrigatório do dever de atingir uma finalidade antecipadamente estabelecida através do manejo de poderes exercitáveis no interesse de outrem, e estabelecido que a lei sempre e sempre impõe, como é natural, o dever de buscar-se a medida que atenda de modo preciso sua finalidade, resulta certo que a liberdade administrativa acaso conferida por uma norma de direito não significa sempre liberdade de eleição entre indiferentes jurídicos. Não significa poder de opções livres, como as do direito privado. Significa o dever jurídico funcional (questão de legitimidade e não de mérito) de acertar, ante a configuração do caso concreto, a providência - isto é, o ato ideal, capaz de atingir com exatidão a finalidade da lei, dando, assim, satisfação ao interesse de terceiros - interesse coletivo e não do agente - tal como firmado na regra aplicanda $^{561}$.
\end{abstract}

Portanto, havendo necessidade de limitação de empenho, as unidades orçamentárias deverão proceder à seleção dos programas a serem privilegiados, em face das circunstâncias concretas existentes, de forma a procurar garantir o maior nível possível de exequibilidade dos programas governamentais, em face das restrições fiscais havidas.

Há que se procurar garantir, conforme exigência de nosso ordenamento, os recursos necessários à execução dos programas e alcance de seus objetivos e metas, com o alcance das metas fiscais, que possibilitam e garantem a indispensável sustentabilidade, no longo prazo, da execução dos programas e projetos essenciais à implementação e concretização dos valores constitucionais.

${ }^{560}$ BANDEIRA DE MELLO, Celso Antônio. Discricionariedade e Controle Jurisdicional. $2^{\mathrm{a}}$ ed., $7^{\mathrm{a}}$ tiragem. São Paulo: Malheiros, 2006, p. 33.

${ }^{561}$ Ibid., p. 47. 
O que muitas vezes ocorre, no funcionamento do sistema orçamentário brasileiro, é a atuação excessivamente conservadora do órgão encarregado da movimentação financeira, que somente libera os limites financeiros depois de se ter certificado do alcance das metas fiscais, em prejuízo do programa de trabalho da unidade.

A prática orçamentária ainda padece desse conservadorismo, justificado, de certa forma, em razão de tradicionais e arraigadas posturas de populismo fiscal, em que se acumulavam déficits e desequilíbrios fiscais, que, de modo irrevogável, impõem pesos e obrigações para gerações futuras, em termos de compensação financeira.

Contudo, juridicamente, há que se procurar atender aos ditames de coordenação e compatibilidade entre objetivos fiscais e objetivos programáticos, sem prejuízo desnecessário à execução dos programas. Afinal, como destaca Burkhead: "O orçamento é o reflexo, tanto das decisões do Executivo sobre o nível dos programas específicos, como também das decisões sobre a política fiscal em conjunto" ${ }^{, 562}$.

Com vistas a assegurar a sustentabilidade fiscal da despesa, para não se prejudicar o regime de responsabilidade fiscal, é que se exige, para a criação, expansão e aperfeiçoamento de qualquer ação governamental que acarrete aumento de despesa, a estimativa do impacto orçamentário-financeiro e a compatibilidade do aumento com o PPA e a $\mathrm{LDO}^{563}$. E, por compatibilidade da nova despesa criada, deve-se entender a despesa que se conforme com as diretrizes, objetivos, prioridades e metas previstos no PPA e LDO e que não infrinja qualquer de suas disposições ${ }^{564}$.

A criação de despesa obrigatória de caráter continuado, entendida como aquela que fixe para o ente a obrigação legal de sua execução por um período superior a dois exercícios, também deve ser acompanhada da comprovação de que sua elaboração não afetará as metas de resultado fiscal previstas na $\mathrm{LDO}^{565}$.

Destarte, o atual ordenamento encontra-se devidamente coordenado, possibilitando que se busque a compatibilidade entre os vários objetivos. Isso não impede que ocorram conflitos, sejam verticais, entre objetivos de distintas leis orçamentárias, ou horizontais, entre objetivos de uma mesma peça orçamentária, a exemplo dos vários programas constantes da Lei Orçamentária Anual. Tais conflitos deverão ser enfrentados considerando-se princípios jurídicos como o da proporcionalidade e da razoabilidade, além

\footnotetext{
${ }_{562}^{562}$ BURKHEAD, Jesse. Orçamento Público. Rio de Janeiro: Fundação Getúlio Vargas, 1971, p. 407/408.

${ }^{563}$ Art. 16, I e II, da LRF.

${ }^{564}$ Art. $16, \S 1^{\circ}$, II, LRF.

${ }^{565}$ Art. $17, \S \S 1^{\circ}$ e $2^{\circ}$, LRF.
} 
de critérios como o da hierarquia de objetivos, por meio do qual objetivos maiores devem prevalecer sobre objetivos menores.

\subsection{Autorização para créditos suplementares e alterações da Lei de Orçamento}

A teoria clássica do Orçamento, ao se concentrar e privilegiar a análise das receitas e das despesas, praticamente desconsiderou a questão das autorizações para abertura de créditos suplementares, ou, dito de forma mais ampla, das autorizações concedidas para que pudessem ser realizadas modificações ou adequações da Lei de Orçamento.

Laband, investigando o ordenamento prussiano, destaca que a utilização de dotações orçamentárias acima dos limites consignados na Lei de Orçamento requereria a aprovação posterior do Legislativo, que, nesse caso, equivaleria a uma retificação do Orçamento. Em suas palavras:

En la Ley Constitucional prusiana (...) se limita a disponer en el párrafo 1 del artículo 104 que:

'En los casos de extralimitaciones presupuestarias será necesaria la aprobación posterior de las Cámaras'.

De lo dicho hasta aquí se deduce el carácter que ostenta la aprobación posterior por las Cámaras de las infracciones del Presupuesto. Hay que concebirla como una rectificación del Presupuesto primitivo, como un complemento y enmienda del mismo ${ }^{566}$.

É ainda Laband que ressalta o entendimento manifestado pela Câmara dos Deputados no sentido de que não se poderia exceder os montantes consignados, mesmo que por meio de compensação equivalente em outra dotação, a menos que a lei orçamentária houvesse autorizado uma transferência dessa natureza:

Con arreglo a una idea, reiterada y consecuentemente postulada por la Cámara de Diputados prusiana, es vinculante para el Gobierno toda partida presupuestaria concreta tal como se haya incluido en el proyecto de Presupuesto presentado a la Cámara y haya sido aprobada por ésta, o sea, son vinculantes todos los detalles y pormenores del llamado Presupuesto administrativo; el Gobierno no puede sobrepasar en ninguno de los gastos la suma presupuestada, ni siquiera en el caso de que en otros gastos se hayan hecho unos ahorros equivalentes en su cuantía, a menos que la misma ley presupuestaria haya autorizado una transferencia de esta naturaleza ${ }^{567}$.

\footnotetext{
${ }^{566}$ LABAND, Paul. Derecho Presupuestario. Trad. Jose Zamit. Madrid: Instituto de Estudios Fiscales, 1979, p. 95.

${ }^{567}$ LABAND, Paul, op. cit., p. 97.
} 
Todavia, tais autorizações são apenas mencionadas na obra de Laband. E, de qualquer forma, as infrações ao Orçamento não acarretariam consequências para o Governo, de acordo com esse autor:

\begin{abstract}
Por consiguiente, el Parlamento ha de limitarse única y exclusivamente a negar la autorización de las infracciones presupuestarias y de los gastos extrapresupuestarios y a rechazar el descargo del Gobierno. Es posible que la no concesión del descargo le resulte inoportuna al Gobierno; pero está fuera de toda duda que ello no acarrea consecuencias prácticas de ninguna especie y que, en último término, tal vez el ministerio se acostumbre a prescindir del descargo otorgado por el Parlamento o del otorgado por una de las dos Cámaras que lo componen ${ }^{568}$.
\end{abstract}

$\mathrm{Na}$ doutrina francesa, a questão das autorizações orçamentárias não é sequer mencionada. Jèze concentra toda sua análise na natureza jurídica do Orçamento das Despesas e do Orçamento das Receitas, sem investigação acerca de outros dispositivos ou seções da Lei de Orçamento ${ }^{569}$.

No ordenamento brasileiro, a autorização para abertura de créditos suplementares se constitui em elemento central da Lei de Orçamento e, sem o devido exame de seu caráter, não é possível que se complete a investigação da complexa natureza da lei orçamentária.

A Constituição Federal de 1988, expressamente, investe a Lei de Orçamento da competência de regulamentar, por meio de seus dispositivos, a abertura de créditos suplementares $^{570}$. No mesmo sentido do texto constitucional, a Lei $\mathrm{n}^{\mathrm{o}}$ 4.320/64 deixa assentada a possibilidade de a LOA autorizar o Executivo a abrir créditos suplementares, até determinada importância ${ }^{571}$.

Os créditos suplementares representam um reforço às dotações constantes da Lei de Orçamento aprovada pelo Poder Legislativo. Dessa forma, encontrando-se vedada a realização de despesas ou assunção de obrigações diretas que excedam os créditos orçamentários $^{572}$, o próprio texto constitucional facultou que, por intermédio de créditos adicionais, fosse viabilizada a alteração da Lei de Orçamento.

A importância dos créditos orçamentários e adicionais - suplementares, especiais e extraordinários - revela-se pelo extenso tratamento da matéria dada pelo legislador constituinte. Nesse sentido, a Carta de 1988 vedou a abertura de crédito suplementar ou

\footnotetext{
${ }^{568}$ Ibid., p. 115.

569 JÈZE, Gaston. Cours de Science des Finances et de Législation Financière Française. Sixième Édition. Paris: Marcel Giard, 1922, p. 24/26.

${ }_{570}$ Art. $165, \S 8^{\circ}, \mathrm{CF} / 88$.

${ }^{571}$ Art. $7^{\circ}$, I, da Lei ${ }^{\circ}$ 4.320/64.

${ }^{572}$ Art. 167, II, CF/88.
} 
especial sem autorização legislativa e sem indicação dos recursos correspondentes ${ }^{573}$; proibiu a transposição, remanejamento ou transferência de recursos de uma categoria de programação para outra ou de um órgão para outro, sem prévia autorização legislativa ${ }^{574} \mathrm{e}$ ainda vedou a concessão ou utilização de créditos ilimitados ${ }^{575}$.

Ademais, o texto constitucional também traçou regras relativas aos créditos especiais e extraordinários ${ }^{576}$ e delimitou a abertura de crédito extraordinário, que somente será admitida para atender a despesas imprevisíveis e urgentes, como as decorrentes de guerra, comoção interna ou calamidade pública ${ }^{577}$.

$\mathrm{Na}$ legislação pátria, os créditos adicionais classificam-se em três espécies ou modalidades $^{578}$ : i) suplementares, destinados ao reforço de dotações orçamentárias; ii) especiais, destinados a despesas para as quais não haja dotação orçamentária específica; e iii) extraordinários, assim considerados aqueles destinados a despesas urgentes e imprevistas, em caso de guerra, comoção intestina ou calamidade pública.

Portanto, para que despesas não computadas ou insuficientemente dotadas na Lei de Orçamento possam ser validamente executadas há necessidade de se recorrer aos créditos adicionais $^{579}$. A abertura dos créditos suplementares e especiais depende da existência de recursos disponíveis para ocorrer à despesa e será precedida de exposição justificativa ${ }^{580}$.

Antes de se adentrar o exame das autorizações para abertura de créditos suplementares e outras alterações orçamentárias, há que se destacar que a Lei de Orçamento, na esfera federal, é excessivamente delineada. Há inúmeros detalhamentos dos créditos orçamentários constantes da Lei de Orçamento: fontes de recursos, modalidades de aplicação, identificadores de uso, identificadores de resultado primário, metas, produtos, unidades de medida, subtítulos, programas, ações, unidades administrativas, grupos de natureza de despesa e funções de governo.

Não por outro motivo, alguns estudiosos classificam a Lei de Orçamento federal como uma das mais detalhadas do mundo:

Um outro fator que dificulta a comparação internacional das práticas orçamentárias no Poder Legislativo tem a ver com os diferentes graus de detalhamento das leis

\footnotetext{
${ }^{573}$ Art. $167, \mathrm{~V}, \mathrm{CF} / 88$.

${ }^{574}$ Art. 167, VI, CF/88.

575 Art. 167, VII, CF/88.

${ }^{576}$ Art. $167, \S 2^{\circ}, \mathrm{CF} / 88$.

577 Art. 167, § 3 ${ }^{\circ}, \mathrm{CF} / 88$.

${ }^{578}$ Art. 41, I, II e III, da Lei no ${ }^{\circ} 4.320 / 64$.

${ }^{579}$ Art. 40 da Lei $n^{\circ} 4.320 / 64$.

${ }^{580}$ Art. 43, caput, da Lei no 4.320/64.
} 
orçamentárias dos diversos países. A lei orçamentária brasileira é possivelmente a mais detalhada do mundo. Classificadores padrões encontrados em leis orçamentárias de países desenvolvidos, muitas vezes de forma mais agregada, como a estrutura administrativa, as funções de governo, os programas, as ações e os subtítulos, os grupos de natureza da despesa e as fontes de recursos constam na lei orçamentária brasileira de forma bastante desagregada. Além desses classificadores, constam também da lei brasileira atributos sui-generis, como a esfera orçamentária, o identificador de resultado primário, a modalidade de aplicação e o identificador de uso. Como resultado desse excessivo detalhamento da programação orçamentária, e também de restrições impostas pela lei de diretrizes orçamentárias e pela própria lei orçamentária quanto à execução da LOA, o Congresso brasileiro acaba envolvendo-se na definição e alteração de detalhes da programação que deveriam ficar restritos a uma análise de cunho técnico ${ }^{581}$.

Pode-se dividir o gênero alterações orçamentárias em duas espécies principais: i) aquelas relacionadas com as dotações orçamentárias; e ii) as referentes às alterações dos demais detalhamentos do crédito orçamentário, constantes da Lei de Orçamento, e.g,. modalidade de aplicação, identificador de uso, identificador de resultado primário, grupo de natureza de despesa, esfera orçamentária.

Em face do ditame constitucional, o tratamento das autorizações para abertura de créditos suplementares encontra-se reservado à LOA, enquanto que a Lei de Diretrizes Orçamentárias, incumbida do estabelecimento de normas para a elaboração dessa Lei ${ }^{582}$, tradicionalmente tem estabelecido regras para alterações dos demais detalhamentos da Lei de Orçamento, bem como acerca dos encaminhamentos de projetos de lei de modificação do Orçamento ao Poder Legislativo.

Feitas tais considerações, passasse a examinar alguns dos dispositivos constantes da Lei de Diretrizes Orçamentárias ${ }^{583}$ que regulamentam as alterações orçamentárias.

Segundo a LDO, as fontes de recursos, as modalidades de aplicação e os identificadores de uso e de resultado primário, as metas, os produtos e as unidades de medida das ações constantes da Lei Orçamentária e dos créditos adicionais podem ser modificados, justificadamente, para atender às necessidades de execução ${ }^{584}$. Para tanto, a própria LDO prevê a modalidade de alteração e o respectivo instrumento normativo que poderá autorizar referidas alterações da LOA.

Para a redução de dotações de modalidades de aplicação ${ }^{585}$ relativas às que tenham sido incluídas pelo Congresso Nacional, inclusive da 99, desde que verificada a

\footnotetext{
581 TOLLINI, Helio, op. cit., p. 06.

582 Art. $165, \S 2^{\circ}, \mathrm{CF} / 88$.

${ }^{583}$ Há, na LDO para 2010, uma Seção inteira (Seção VIII) para tratar das alterações da Lei Orçamentária, que se estende do art. 55 ao art. 67 daquela Lei.

${ }_{584}$ Art. 55, caput, da Lei n ${ }^{\circ} 12.017 / 09$ (LDO para 2010).

585 A modalidade de aplicação destina-se a indicar se os recursos serão aplicados: I - diretamente, pela unidade detentora do crédito orçamentário ou, mediante descentralização de crédito orçamentário, por outro
} 
inviabilidade técnica, operacional ou legal de sua execução na forma prevista na Lei Orçamentária, a LDO exige autorização por meio de portaria do dirigente máximo do órgão a que estiver subordinada ou vinculada a unidade orçamentária ${ }^{586}$.

As demais alterações relativas a modalidades de aplicação são realizadas diretamente no Sistema Integrado de Administração Financeira do Governo Federal SIAFI pela unidade orçamentária ${ }^{587}$.

Para que se torne possível a alteração das fontes de recursos $^{588}$ dos Orçamentos Fiscal e da Seguridade Social previstas na Lei Orçamentária, igualmente para a modificação de identificadores de uso $^{589}$ e de resultado primário ${ }^{590}$, a LDO exige a autorização mediante portaria do Secretário de Orçamento Federal ${ }^{591}$.

As metas, produtos e unidades de medidas das ações constantes da LOA somente podem ser modificadas desde que constatado erro material de ordem técnica ou legal, exigindo, também nesse caso, a publicação de portaria do Secretário de Orçamento Federal $^{592}$.

A LDO ainda disciplina o encaminhamento de projetos de lei relativos a créditos suplementares e especiais.

Os projetos de lei relativos a créditos suplementares e especiais devem ser instruídos com exposições de motivos circunstanciadas que os justifiquem e que indiquem as consequências dos cancelamentos de dotações propostos sobre a execução das atividades, projetos, operações especiais e respectivos subtítulos e metas ${ }^{593}$.

órgão ou entidade integrante dos Orçamentos Fiscal ou da Seguridade Social; ou II - indiretamente, mediante transferência financeira, por outras esferas de governo, seus órgãos, fundos ou entidades ou por entidades privadas sem fins lucrativos (art. $7^{\circ}, \S 7^{\circ}$, LDO para 2010).

${ }_{586}$ Art. 55, inciso I, da Lei $\mathrm{n}^{\mathbf{0}} 12.017 / 09$ (LDO para 2010).

${ }^{587}$ Art. 55, $\S 2^{\circ}$, da Lei ${ }^{\circ} 12.017 / 09$ (LDO para 2010).

${ }^{588}$ A classificação orçamentária por fontes de recursos foi instituída pela Portaria $\mathrm{SOF} \mathrm{n}^{\circ} 1 / 2001$, tendo em vista a necessidade de identificar nas alterações orçamentárias se os recursos pertencem ao exercício corrente ou a exercícios anteriores. O código de classificação de fontes de recursos é composto por três dígitos, sendo que o primeiro indica o grupo de fontes de recursos (1 - Recursos do Tesouro - exercício corrente; 2 Recursos de outras fontes - exercício corrente; 3 - Recursos do Tesouro - exercícios anteriores; 4 - Recursos de outras fontes - exercícios anteriores; 9 - Recursos condicionados), e o segundo e terceiro a especificação das fontes de recursos (e.g. 00 - recursos ordinários; 12 - recursos destinados à manutenção e desenvolvimento do ensino; 29 - recursos de concessões e permissões; 50 - recursos próprios não financeiros, etc.).

${ }^{589} \mathrm{O}$ identificador de uso destina-se a indicar se os recursos compõem contrapartida nacional de empréstimos ou de doações, ou destinam-se a outras aplicações (Art. $7^{\circ}, \S 11$, LDO para 2010).

${ }^{590} \mathrm{O}$ identificador de resultado primário tem como finalidade auxiliar a apuração do resultado primário, identificando se a despesa é: I - financeira; II - primária obrigatória; III - primária discricionária; IV primária discricionária relativa ao PAC; V - do Orçamento de Investimento das empresas estatais que não impacta o resultado primário (Art. $7^{\circ}, \S 4^{\circ}$, LDO para 2010).

${ }_{591}$ Art. 55, inciso III, da Lei $\mathrm{n}^{\circ}$ 12.017/09 (LDO para 2010).

${ }^{592}$ Art. 55, inciso IV, da Lei $n^{\circ} 12.017 / 09$ (LDO para 2010).

${ }^{593}$ Art. 56, § 5 ${ }^{\circ}$, da Lei $n^{\circ} 12.017 / 09$ (LDO para 2010). 
Além disso, os projetos de lei de créditos suplementares e especiais destinados a despesas primárias deverão conter demonstrativo de que não afetam o resultado primário anual previsto no Anexo de Metas Fiscais, com a indicação, quando for o caso, dos cancelamentos compensatórios ${ }^{594}$.

Relativamente às autorizações para abertura de créditos suplementares, a Lei $\mathrm{n}^{\circ}$ 11.897/08, LOA para 2009, possui, em seu Capítulo II, que trata dos Orçamentos Fiscal e da Seguridade Social, uma Seção inteiramente dedicada a disciplinar referida autorização.

Em nosso ordenamento, existem dois meios de se proceder à abertura de créditos suplementares: i) por meio de decreto do Presidente da República, nos casos em que existe expressa autorização no texto da Lei de Orçamento $^{595}$; e ii) mediante encaminhamento de projeto de lei, nas hipóteses em que se excede a autorização contida na LOA ou quando não existe autorização específica nela, havendo, nesses casos, necessidade de autorização própria do Poder Legislativo ${ }^{596}$.

É sintomático o nível de detalhamento e de pormenorização a que desce o Poder Legislativo no tratamento do tema, de que é indicação veemente o fato de existir, em uma lei que contém treze artigos, um artigo - art. $4^{\circ}$ da LOA - contendo mais de cinquenta dispositivos referentes à possibilidade e respectivas circunstâncias de abertura de créditos suplementares. Por extensa que seja, relevante para os fins deste trabalho será a transcrição das regras estabelecidas na LOA:

Art. 4ํ Fica autorizada a abertura de créditos suplementares, restritos aos valores constantes desta Lei, desde que as alterações promovidas na programação orçamentária sejam compatíveis com a obtenção da meta de resultado primário estabelecida no Anexo de Metas Fiscais da Lei de Diretrizes Orçamentárias para 2009 e sejam observados o disposto no parágrafo único do art. $8^{\underline{0}}$ da Lei de Responsabilidade Fiscal, na Lei de Diretrizes Orçamentárias para 2009 os limites e condições estabelecidos neste artigo, para suplementação de dotações consignadas:

I - a cada subtítulo, até o limite de $10 \%$ (dez por cento) do respectivo valor, mediante a utilização de recursos provenientes de:

a) anulação parcial de dotações, limitada a $10 \%$ (dez por cento) do valor do subtítulo objeto da anulação, vedado o cancelamento de programações decorrentes da aprovação de emendas individuais apresentadas pelos parlamentares, a serem informadas ao Poder Executivo pelo Congresso Nacional;

b) reserva de contingência, inclusive à conta de recursos próprios e vinculados, observado o disposto no art. 5\%, inciso III, da Lei de Responsabilidade Fiscal; e

\footnotetext{
${ }^{594}$ Art. 56, § 12, da Lei no 12.017/09 (LDO para 2010).

595 Art. 42 da Lei no $4.320 / 64$

${ }^{596}$ A Constituição Federal deixa clara a necessidade de autorização parlamentar para as alterações da Lei de Orçamento. Em determinadas hipóteses, o Legislativo, antecipadamente, circunscreve as condições em que podem ser feitas adequações, sem necessidade de nova submissão do crédito à Casa Legislativa. Todavia, sempre que determinado caso não esteja contemplado nas hipóteses de delegação expressamente autorizadas pelo Congresso, há necessidade de se submeter um projeto de lei específico para a deliberação parlamentar.
} 
c) excesso de arrecadação de receitas próprias, nos termos do art. $43, \S \S 1^{\circ}$, inciso II, 3ํe e $4^{\circ}$, da Lei n⿳ำ 4.320, de 17 de março de 1964;

II - aos grupos de natureza de despesa "3 - Outras Despesas Correntes", "4 Investimentos" e "5 - Inversões Financeiras", mediante utilização de recursos provenientes da anulação de dotações consignadas a esses grupos, no âmbito do mesmo subtítulo, objeto da suplementação, limitada a $20 \%$ (vinte por cento) da soma das referidas dotações;

III - ao atendimento de despesas decorrentes de sentenças judiciais transitadas em julgado, inclusive daquelas consideradas de pequeno valor nos termos da legislação vigente e relativas a débitos periódicos vincendos, mediante a utilização de recursos provenientes de:

a) reserva de contingência, inclusive à conta de recursos próprios e vinculados, observado o disposto no art. $5^{\circ}$, inciso III, da Lei de Responsabilidade Fiscal;

b) anulação de dotações consignadas a grupos de natureza de despesa no âmbito do mesmo subtítulo;

c) anulação de dotações consignadas a essa finalidade, na mesma ou em outra unidade orçamentária;

d) até $10 \%$ (dez por cento) do excesso de arrecadação de receitas próprias e do Tesouro Nacional; e

e) superávit financeiro apurado no balanço patrimonial da União do exercício de 2008, nos termos do art. 43, $\S \S 1^{\circ}$, inciso I, e $2^{2}$, da Lei $\mathrm{n}^{\mathrm{o}} 4.320$, de 1964;

IV - ao atendimento de despesas com juros e encargos da dívida, mediante a utilização de recursos provenientes da anulação de dotações consignadas a essa finalidade ou à amortização da dívida, na mesma ou em outra unidade orçamentária;

V - ao atendimento de despesas com amortização da dívida pública federal, mediante a utilização de recursos provenientes de:

a) anulação de dotações consignadas a essa finalidade ou ao pagamento de juros e encargos da dívida, na mesma ou em outra unidade orçamentária;

b) excesso de arrecadação decorrente dos pagamentos de participações e dividendos pelas entidades integrantes da Administração Pública Federal indireta, inclusive os relativos a lucros acumulados em exercícios anteriores;

c) superávit financeiro apurado no balanço patrimonial do exercício de 2008;

$\mathrm{e}$

d) resultado do Banco Central do Brasil, observado o disposto no art. $7^{\circ}$ da Lei de Responsabilidade Fiscal;

VI - ao atendimento das despesas de pessoal e encargos sociais, inclusive as decorrentes da revisão geral anual de remuneração dos servidores públicos federais e dos militares das Forças Armadas prevista no art. 37, inciso X, da Constituição, e nos arts. 85 e 86 da Lei de Diretrizes Orçamentárias para 2009, mediante a utilização de recursos oriundos da anulação de dotações consignadas:

a) a esse grupo de natureza de despesa no âmbito do respectivo Poder e do Ministério Público da União; e

b) aos grupos de natureza de despesa "3 - Outras Despesas Correntes”, "4 Investimentos" e "5 - Inversões Financeiras", constantes do mesmo subtítulo, objeto da suplementação, até o limite de $20 \%$ (vinte por cento) da soma dessas dotações;

VII - a subtítulos aos quais foram alocadas receitas de operações de crédito previstas nesta Lei, mediante a utilização de recursos decorrentes da variação monetária ou cambial dessas operações;

VIII - a subtítulos aos quais possam ser alocados recursos oriundos de doações e convênios, inclusive decorrentes de saldos de exercícios anteriores ou de remanejamento de dotações à conta dos referidos recursos, observada a destinação prevista no instrumento respectivo;

IX - ao atendimento do refinanciamento, juros e outros encargos da dívida pública federal, mediante a utilização de recursos decorrentes da emissão de títulos de responsabilidade do Tesouro Nacional, inclusive constantes do superávit financeiro apurado no balanço patrimonial da União do exercício de 2008, até o limite de $20 \%$ (vinte por cento) do montante do refinanciamento da dívida pública federal estabelecido no art. $3^{\circ}$, inciso III, desta Lei; 
X - ao atendimento de transferências de que trata o art. 159 da Constituição, bem como daquelas devidas aos Estados, ao Distrito Federal e aos Municípios decorrentes de vinculações legais, mediante a utilização do superávit financeiro correspondente apurado no balanço patrimonial da União do exercício de 2008;

XI - ao atendimento de despesas com equalização de preços nas ações destinadas à execução da Política de Garantia de Preços Mínimos, Formação e Administração de Estoques Reguladores e Estratégicos de produtos agropecuários, mediante a utilização de recursos provenientes de anulação de dotações consignadas a essas despesas no âmbito do órgão "Operações Oficiais de Crédito";

XII - ao atendimento de despesas com benefícios previdenciários, mediante a utilização de recursos provenientes de:

a) anulação de dotações consignadas a essas despesas no âmbito do Fundo do Regime Geral de Previdência Social;

b) excesso de arrecadação das contribuições previdenciárias para o Regime Geral de Previdência Social; e

c) superávit financeiro apurado no balanço patrimonial da União do exercício de 2008;

XIII - ao atendimento de despesas da ação "0413 - Manutenção e Operação dos Partidos Políticos" no âmbito da unidade orçamentária "14901 - Fundo Partidário", mediante a utilização de recursos provenientes de:

a) superávit financeiro apurado no balanço patrimonial do exercício de 2008;

$\mathrm{e}$

b) excesso de arrecadação de receitas próprias e vinculadas;

XIV - ao atendimento de despesas no âmbito da Fundação Joaquim Nabuco, do Instituto Nacional de Educação de Surdos, do Instituto Benjamim Constant, do Colégio Pedro II, das Instituições Federais de Ensino Superior, das Escolas Técnicas Federais, dos Centros Federais de Educação Tecnológica, das Escolas Agrotécnicas Federais e dos Hospitais Universitários, integrantes do Ministério da Educação, classificadas nos grupos de natureza de despesa "3 - Outras Despesas Correntes", "4 Investimentos" e "5 - Inversões Financeiras", mediante a utilização de recursos provenientes de:

a) anulação de até $20 \%$ (vinte por cento) do total das dotações orçamentárias consignadas a esses grupos de natureza de despesa no âmbito de cada uma das entidades;

b) excesso de arrecadação de receitas próprias geradas por essas entidades;

c) superávit financeiro, relativo a receitas próprias e vinculadas, apurado no balanço patrimonial do exercício de 2008 , de cada uma das referidas entidades; e

d) superávit financeiro apurado no balanço patrimonial da União do exercício de 2008, relativo a receitas vinculadas à educação, até o limite do saldo orçamentário de cada subtítulo, nos referidos grupos de natureza de despesa, não utilizado no exercício de 2008, desde que para aplicação nos mesmos subtítulos em 2009;

XV - ao atendimento de despesas no âmbito do Ministério da Educação, classificadas nos grupos de natureza de despesa "3 - Outras Despesas Correntes", "4 Investimentos" e "5 - Inversões Financeiras", mediante a utilização de recursos provenientes de superávit financeiro apurado no balanço patrimonial da União do exercício de 2008, relativo a receitas vinculadas à educação, até o limite do saldo orçamentário de cada subtítulo apurado em 31 de dezembro de 2008, nos referidos grupos de natureza de despesa, vinculados às subfunções "361 - Ensino Fundamental", “362 - Ensino Médio”, “363 - Ensino Profissional”, "364 - Ensino Superior” e "847 Transferências para a Educação Básica”, não utilizado no exercício de 2008, desde que para aplicação nos mesmos subtítulos em 2009;

XVI - ao atendimento de despesas da ação "0E36 - Complementação da União ao Fundo de Manutenção e Desenvolvimento da Educação Básica e de Valorização dos Profissionais da Educação - FUNDEB”, mediante a utilização de recursos provenientes de:

a) superávit financeiro apurado no balanço patrimonial do exercício de 2008;

b) excesso de arrecadação de receitas vinculadas; e

c) anulação parcial ou total de dotações alocadas aos subtítulos dessa ação;

XVII - ao pagamento de benefícios a novos servidores, empregados e seus dependentes, mediante a anulação de dotações consignadas ao Ministério do 
Planejamento, Orçamento e Gestão no subtítulo "Pagamento decorrente de Provimentos e Concessão de Benefícios aos Servidores, Empregados e seus Dependentes Nacional”, GND “3 - Outras Despesas Correntes”;

XVIII - ao atendimento de programações constantes do Anexo VII desta Lei, mediante o remanejamento de até $30 \%$ (trinta por cento) do montante das dotações orçamentárias constantes desta Lei com o identificador de resultado primário "3”;

XIX - ao atendimento de despesas com o pagamento do abono salarial e do seguro desemprego, mediante a utilização de recursos provenientes de:

a) anulação de dotações consignadas a essas despesas no âmbito do Fundo de Amparo ao Trabalhador; e

b) superávit financeiro apurado no balanço patrimonial da União do exercício de 2008;

XX - à suplementação de ações do Programa de Aceleração do Crescimento PAC, classificadas com identificadores de resultado primário "1" ou "2", identificadas no SIAFI, até o limite de $30 \%$ (trinta por cento) de cada ação, mediante o cancelamento de até $30 \%$ (trinta por cento) de cada ação orçamentária, também identificada no SIAFI como integrante desse Programa; e

XXI - a subtítulos das ações do programa "0910 - Operações Especiais: Gestão da Participação em Organismos Internacionais”, mediante a anulação de dotações orçamentárias contidas no mesmo programa, desde que não incida sobre subtítulos derivados integralmente de alterações efetuadas pelo Congresso Nacional no Projeto de Lei Orçamentária de 2009.

$\S 1^{\circ}$ o Os limites referidos no inciso I e respectiva alínea "a" deste artigo poderão ser ampliados quando o remanejamento:

I - ocorrer entre ações de um mesmo programa no âmbito de cada unidade orçamentária, para $30 \%$ (trinta por cento);

II - destinar-se ao atendimento dos benefícios auxílio-alimentação ou refeição, assistência médica e odontológica, assistência pré-escolar e auxílio-transporte aos servidores, empregados, e seus dependentes, para 30\% (trinta por cento); e

III - destinar-se a recompor despesas correntes.

$\S 2^{\underline{0}}$ A autorização de que trata este artigo fica condicionada à publicação, até o dia 15 de dezembro de 2009, do ato de abertura do crédito suplementar, exceto nos casos previstos nos incisos III, VI, XII e XIX do caput e inciso II do $\S 1^{\circ}$, deste artigo, em que a publicação poderá ocorrer até 31 de dezembro de 2009.

$\mathrm{O}$ art. $5^{\circ}$ da LOA também regulamenta a abertura de créditos suplementares, nos termos seguintes:

Art. 5ำ Fica o Poder Executivo autorizado a abrir créditos suplementares à conta de recursos de excesso de arrecadação, nos termos do art. $43, \S \S 1^{\circ}$, inciso II, $3^{\circ}$ e $4^{\circ}$, da Lei no 4.320, de 1964, destinados:

I - a transferências aos Estados, ao Distrito Federal e aos Municípios, decorrentes de vinculações constitucionais ou legais;

II - aos fundos constitucionais de financiamento do Norte, Nordeste e Centro-Oeste, nos termos da Lei $\mathrm{n}^{\mathrm{O}}$ 7.827, de 27 de setembro de 1989;

III - ao Fundo de Amparo ao Trabalhador - FAT, mediante a utilização de recursos das contribuições para o Programa de Integração Social - PIS e o Programa de Formação do Patrimônio do Servidor Público - PASEP, inclusive da parcela a que se refere o art. 239, § $1^{\circ}$, da Constituição; e

IV - ao complemento da atualização monetária do saldo do Fundo de Garantia do Tempo de Serviço - FGTS, mediante a utilização de recursos da contribuição relativa à despedida de empregado sem justa causa, de que trata o art. $1^{\circ}$ da Lei Complementar n⿳0 110, de 29 de junho de 2001. 
Do exame dos referidos dispositivos, depreende-se que a questão da regulamentação dos créditos suplementares é matéria centralmente orçamentária, integrando o conteúdo da LOA por determinação direta da Constituição Federal.

A regulamentação extensa e detalhada dá a medida da importância do tema pelo Poder Legislativo, que não concede autorizações generalizadas ao Poder Executivo durante o processo de execução do Orçamento. Ao contrário, nesse sistema, parece que se caminha para um controle minucioso das movimentações, em certa medida formalístico e distinto do controle de resultados - controle esse a posteriori, por excelência.

De toda forma, há que se ressaltar que não existe, em nenhuma outra lei, o tratamento das autorizações e adequações das dotações orçamentárias, por meio de créditos suplementares. Portanto, não há como se afirmar que, nessa parte, o Orçamento seria um ato-condição, apenas condição de eficácia para o exercício de outras competências ou para a validade de outras leis, ou meramente lei formal, ato administrativo editado sob a forma de lei. Tal é o campo, por excelência, em que o Legislativo pode cunhar regras que deverão ser observadas por todos aqueles encarregados da execução da lei, notadamente pelo Poder Executivo.

Relativamente aos créditos suplementares e suas alterações, a Lei de Orçamento inova o ordenamento jurídico, regulamentando a possibilidade de alterações, de acordo com a natureza e extensão previamente determinadas pelo Legislador. Há, nesse caso, o estabelecimento de regras de direito abstratas e impessoais, válidas para todos os órgãos da Administração Pública federal para o período de vigência da LOA, que devem, obrigatoriamente, ser observadas durante o processo de execução do Orçamento.

As regras fixadas na seção que trata da autorização para abertura de créditos suplementares consubstanciam, simultaneamente, uma autorização para suplementação de recursos, quando necessário, e uma proibição de movimentação ou alteração das dotações orçamentárias em níveis superiores àqueles fixados pela Lei de Orçamento, ou em circunstâncias ou hipóteses diferentes do que aquelas taxativamente estabelecidas ou fixadas pelas regras.

Pode-se criticar o nível de detalhamento de que se vale o Legislativo na esfera federal, que termina por dificultar, em muito, o trabalho da execução orçamentária, visto que, em muitas hipóteses, há necessidade de encaminhamento de projetos de lei ao Legislativo para alterações que, na prática, muito pouco representam. 
Contudo, se pode haver uma crítica na tentativa deliberada do Congresso em se imiscuir na execução do Orçamento, controlando-o por meio do estabelecimento de uma infinidade de regras, não se pode deixar de reconhecer que aqui o Legislativo exercita o poder de deliberar em que circunstâncias e sob quais hipóteses estará autorizado o Poder Executivo a alterar a Lei de Orçamento aprovada pelo Parlamento.

\subsection{Condicionamento da legislação permanente pelas leis orçamentárias}

Nos termos propostos pela teoria clássica da Lei de Orçamento, a lei orçamentária estaria condicionada pela legislação permanente, tanto pela ótica das receitas quanto pelo lado das despesas, visto que "la fijación del Presupuesto es un acto administrativo que debe llevarse a cabo de acuerdo con las leyes" $" 597$. No mesmo sentido, é a síntese de Canotilho:

Segundo a doutrina clássica, a lei do orçamento, além de não ser uma lei material por não conter regras de direito, também não se podia considerar como legislação livre. (...) É nesse contexto que se assinala à lei do orçamento o carácter de legislação vinculada, legal e constitucionalmente ${ }^{598}$.

Cabe destacar que o fato de se encontrar submetida às regras e princípios constitucionais, não torna a Lei de Orçamento, nesse tocante, diferente de qualquer outra espécie normativa, uma vez que todas devem obediência à sistemática constitucional, seja no que respeita ao campo próprio e peculiar de incidência, seja quanto à extensão das matérias de que poderão tratar, seja, ainda, das limitações traçadas por outras regras e ditames constitucionais.

Além disso, todas as leis podem, sob certos aspectos, encontrar limites e condicionantes oriundos de outras leis - ainda que de idêntica hierarquia. É o que ocorre quando uma determinada lei utiliza definições ou conceituações que foram objeto de tratamento por meio de outra lei - que possuía competência para tratar da matéria, lex specialis derogat generali. Dessa forma, não pode a primeira lei pretender modificar, nesse

${ }^{597}$ LABAND, Paul. Derecho Presupuestario. Trad. Jose Zamit. Madrid: Instituto de Estudios Fiscales, 1979 , p. 39.

${ }^{598}$ CANOTILHO, José Joaquim Gomes. A Lei do Orçamento. In: Estudos em Homenagem ao Prof. Doutor J. J. Teixeira Ribeiro. Universidade de Coimbra: Boletim da Faculdade de Direito, Número Especial, 1979, p. $553 / 554$. 
aspecto, definição balizada pela norma própria de competência, assim, encontra condicionantes advindos de outro ato normativo.

Portanto, o fato de a Lei de Orçamento estar, sob certos aspectos, condicionada por regras constitucionais e legais, pouco diz a respeito do caráter próprio da lei orçamentária, representando, antes, uma regra de generalizada incidência a que se encontram sujeitas as leis. Aliás, o ordenamento jurídico nada mais representa do que um plexo de leis de distintas hierarquias e diferentes campos de incidência, que, de certo modo, se encontram amalgamadas e ordenadas, instituindo o complexo legal a que se deve obediência.

Parte da comprovação do que se afirma é revelada pelo condicionamento exercido pela própria Lei de Orçamento em relação a outras leis. Efetivamente, a LOA condiciona diversas leis e atos administrativos, bem como os próprios contratos administrativos, os quais somente adquirirão a vigência indispensável desde que sejam, previamente, validadas pela lei orçamentária.

A Lei $n^{\circ}$ 8.666/93, que institui normas para licitações e contratos da Administração Pública, no âmbito dos Poderes da União, dos Estados, do Distrito Federal e dos Municípios, deixa expressamente consignado que as obras e serviços somente poderão ser licitados quando houver previsão de recursos orçamentários que assegurem o pagamento das obrigações decorrentes de obras e serviços a serem executadas no exercício financiero em curso ${ }^{599}$. Mais do que isso, a falta de previsão dos recursos orçamentários implica em nulidade dos atos ou contratos realizados e a responsabilidade de quem lhes tenha dado causa $^{600}$. Adicionalmente, nenhuma compra será feita sem a indicação dos recursos orçamentários para seu pagamento, sob pena de nulidade do ato e responsabilidade de quem lhe tiver dado causa ${ }^{601}$.

A Lei de Licitações ainda estabelece como cláusula necessária de todo contrato a fixação do crédito pelo qual correrá a despesa, com a indicação da classificação funcional programática e da categoria econômica ${ }^{602}$.

Nosso ordenamento, portanto, subordina a contratualização à prévia existência de recursos orçamentários. Assim, o raciocínio é inverso àquele desenvolvido pelos autores filiados à corrente orçamentária clássica, notadamente por Laband ${ }^{603}$ e Jèze. Não são as

\footnotetext{
${ }^{599}$ Art. $7^{\circ}, \S 2^{\circ}$, III, da Lei $n^{\circ} 8.666 / 93$.

${ }^{600}$ Art. $7^{\circ}, \$ 6^{\circ}$, da Lei $n^{\circ} 8.666 / 93$.

${ }^{601}$ Art. 14 da Lei $\mathrm{n}^{\circ} 8.666 / 93$.

${ }^{602}$ Art. 55, V, da Lei no 8.666/93.

${ }^{603}$ Segundo Laband, as "obligaciones jurídico-civiles del Tesoro Público (...) imponen unas limitaciones a la supresión de partidas en los proyectos presupuestarios". LABAND, Paul, op. cit., p. 35. No ordenamento brasileiro, é a Lei de Orçamento que impõe limitações à contratação na Administração Pública.
} 
obrigações decorrentes de contratos firmados pelo Estado, que, ao consubstanciarem dívidas para o Estado, impõem que se preveja, na lei orçamentária, a necessária dotação para viabilizar o pagamento das obrigações contratuais. O que ocorre é exatamente o oposto. Para a contratualização, exige o ordenamento jurídico que, de forma prévia, demonstre o administrador público a existência de suficiente dotação orçamentária que garanta o posterior cumprimento da obrigação a ser gerada pela execução do serviço ou entrega do produto pelo particular.

Aliás, tal sistemática encontra amparo em um regime que se pretende austero em termos de responsabilidade fiscal. Não pode o Estado sair contratando, sem saber se haverá, no futuro, recursos suficientes para o cumprimento das obrigações que gera. Ao contrário, impõe-se que, previa e planejadamente, o administrador verifique a sua efetiva capacidade de assumir obrigações, de modo que deverá existir, previamente, dotação orçamentária suficiente. Como destaca Maria Sylvia Zanella Di Pietro:

Quanto aos recursos orçamentários, embora a sua indicação deva constar do contrato, dentre as cláusulas necessárias (art. 55, V, da Lei $\mathrm{n}^{\mathbf{0}}$ 8.666/93), na realidade a verificação de sua existência deve preceder qualquer providência da Administração, até mesmo a licitação, pois não é viável que se cogite de celebrar contrato e se inicie qualquer procedimento, sem a prévia verificação da existência de verbas para atender à despesa $^{604}$.

Em princípio, a própria duração dos contratos ficará adstrita à vigência dos respectivos créditos orçamentários ${ }^{605}$. Di Pietro acrescenta ainda que:

para evitar a celebração de contratos que ultrapassem o exercício financeiro, com comprometimento do orçamento do ano subseqüente, a lei quis fazer coincidir a duração dos contratos com o término do exercício financeiro, só admitindo, para os projetos, prazo superior, quando estejam previstos no Plano Plurianual. Com isto, evita-se a realização de obras e serviços não planejados, que possam acarretar ônus superiores às disponibilidades orçamentárias ${ }^{606}$.

Segundo Jèze, haveria a obrigação prévia dos Ministros de não contratarem sem a existência de créditos orçamentários ou excedendo o montante de créditos disponíveis: "los ministros celebran los contratos (...) Pero tienen la obligación de no contratar sin crédito ni exceder los créditos presupuestarios"

\footnotetext{
${ }^{604}$ DI PIETRO, Maria Sylvia Zanella. Direito Administrativo. $19^{\mathrm{a}}$ ed. São Paulo: Atlas, 2006, p. 272.

${ }^{605}$ Art. 57, caput, da Lei no 8.666/93.

${ }^{606}$ DI PIETRO, Maria Sylvia Zanella, op. cit., p. 270.

607 JÈZE, Gaston. Principios Generales del Derecho Administrativo. Tomo IV. Traducción directa de la $3^{\mathrm{a}}$ edición francesa, por Julio N. San Millán Almagro. Buenos Aires: Editorial Depalma, 1950, p. 12.
} 
Todavia, ao desenvolver sua teoria, Jèze reduz a praticamente nada as consequências de tais infringências pelos administradores públicos:

Cuál es la sanción de estas reglas? Qué influencia jurídica ejerce, sobre el contrato, sobre su existencia y sobre su validez, la violación del principio general de la previa autorización concedida en forma de apertura de un crédito?

La respuesta es evidente. El contrato concluido por un ministro sin crédito o excediendo el crédito aprobado por el Parlamento, o desviando un crédito de su objeto (cambio de destino) o utilizando un crédito para un período para el que no se ha concedido, es jurídicamente válido. La irregularidad no tiene ninguna influencia sobre la existencia ni sobre la validez jurídica del contrato. No puede tampoco invocarse en apoyo de un recurso contencioso relativo al contrato ${ }^{608}$.

Portanto, para o jurista francês, a falta de existência de crédito orçamentário carece de qualquer influência sobre a validade jurídica do contrato firmado pelo Estado ${ }^{609}$.

No Brasil, ao contrário, não é possível se defender tal entendimento, visto que o crédito orçamentário e sua dotação representam uma cláusula necessária e, consequentemente, obrigatória dos contratos celebrados pelo Estado ${ }^{610}$. Ademais, é necessária a previsão de dotações orçamentárias para que o próprio procedimento licitatório possa ser instaurado.

Em face disso, a falta de previsão dos recursos orçamentários imprescindíveis ao custeio do contrato enseja a nulidade do contrato, ou, quando menos, sua irregularidade: "a falta dessa indicação (fonte orçamentária dos recursos financeiros) é motivo para o Tribunal de Contas não considerar o contrato regular" ${ }^{\text {"611 }}$. Fonrouge também defende a irregularidade de um contrato firmado sem a previsão dos recursos orçamentários correspondentes:

Creemos con Duverger, que 'si un acto administrativo es contrario a una disposición presupuestaria (por ejemplo, un compromiso o una orden de pago sin el correspondiente crédito o con crédito insuficiente), dicho acto seria irregular pero no nulo', a condición, naturalmente, de que los terceros sean de buena $\mathrm{fe}^{612}$.

\footnotetext{
${ }^{608}$ JÈZE, Gaston. Principios Generales del Derecho Administrativo. Tomo IV. Traducción directa de la $3^{\mathrm{a}}$ edición francesa, por Julio N. San Millán Almagro. Buenos Aires: Editorial Depalma, 1950, p. 18. ${ }^{609}$ Ibid., p. 21.

${ }^{610}$ Há exceções no caso de contratos que não implicam comprometimento de recursos orçamentários, como as concessões de obras ou serviço público. Nestes casos também não concorrem as razões relativas à regra geral de limitação da duração do contrato à disponibilidade de créditos orçamentários. Cf. BANDEIRA DE MELlo, Celso Antônio. Curso de Direito Administrativo. 20ª ed. São Paulo: Malheiros, 2006, p. 593.

${ }^{611}$ FARIA, Edimur Ferreira de. Curso de Direito Administrativo Positivo. $6^{\mathrm{a}}$ ed. Belo Horizonte: Del Rey, 2007, p. 392.

${ }^{612}$ FONROUGE, Carlos M. Giuliani. Derecho Financiero. Vol. I. $3^{\mathrm{a}}$ ed. Buenos Aires: Depalma, 1977, p. 226.
} 
Considerando-se que a existência de dotação orçamentária é prévia à contratualização, no ordenamento jurídico brasileiro, não há que se falar em inexistência de dotação para o pagamento das obrigações que surgirão.

Laband defende que a validade jurídica de um contrato firmado pelo Estado é independente de qualquer autorização do Parlamento, e, mais do que isso, advoga que, para obrigar o Parlamento a inserir as dotações na Lei de Orçamento, bastaria que fossem firmadas obrigações por meio de contratos. Nesses casos, o Legislativo estaria obrigado a consignar tais dotações na Lei:

Así, pues, dado que la validez jurídico-civil de un negocio jurídico contraído por el Gobierno es independiente de la autorización del Parlamento, el principio de que el Parlamento tiene que aprobar todos los gastos que se deriven de una obligación del Estado válida a efectos jurídico-civiles hace forzosamente ilusorio en su mayor parte el derecho presupuestario del Parlamento. En efecto, todo ministro que tema la supresión de cualquiera de los gastos por él previsto no necesita sino proceder a la firma de un contrato, con el que obligará al fisco, desde un punto de vista jurídico-civil, a la prestación de este pago, a fin de hacerle imposible al Parlamento la no autorización $^{613}$.(g.n.)

Para Laband, confirma-se que a validade do contrato independe de qualquer autorização legislativa, visto que as obrigações do Estado poderiam ser exigidas pelos credores, independentemente de que hajam sido autorizadas pelo Orçamento:

todas las obligaciones del Estados, nacidas de causas válidas a efectos jurídico-civiles, podrán ser reclamadas por los acreedores contra el fisco por la vía procesal y realizadas por la vía ejecutiva contra la Caja General del Estado, con absoluta independencia de que el pago de tales pretensiones haya sido autorizado o no por el Presupuesto ${ }^{614}$.

No ordenamento brasileiro, porém, existe um condicionamento expresso, tanto da licitação (antecedente lógico do contrato) quanto dos contratos, no sentido de haver prévia autorização parlamentar. Logicamente, o Estado não poderá se valer da irregularidade relativa à autorização orçamentária para, posteriormente, se eximir do cumprimento de uma obrigação. Todavia, o fato de o credor poder receber o pagamento, não implica em regularidade dos atos editados e, tampouco, em inexistência de responsabilidade por parte daquele que deu causa à irregularidade.

Parte das razões indicadas por Jèze, para defender a inexistência de qualquer repercussão jurídica em contratos firmados sem autorização orçamentária, são de cunho eminentemente prático, porque, naquela época, não havia sistemas informatizados que

${ }^{613}$ LABAND, Paul, op. cit., p. 60.

${ }^{614}$ Ibid., p. 58. 
possibilitassem e indicassem os saldos das respectivas dotações orçamentárias e, mais do que isso, os registros existentes não se encontrariam à disposição para consulta:

\begin{abstract}
Si la falta de crédito o la circunstancia de haberlo excedido o la intervención de ejercicio entrañasen la inexistencia o la nulidad jurídica del contrato, ninguna persona seria querría contratar con la Administración, en razón del riesgo de la inexistencia o de la nulidad del contrato. Los contratantes no tienen, en efecto, ninguna posibilidad, sea cual fuere su cuidado, de saber si existe un crédito disponible, si no ha habido intervención de ejercicio, o si el Consejo de Ministros ha adoptado una resolución especial, declarando la urgencia y la necesidad nacional. Para saberlo, sería preciso consultar los registros de contabilidad que se llevan en los Ministerios, pero dichos registros no están a disposición de los particulares ${ }^{615}$.
\end{abstract}

Há outros dispositivos que se orientam no mesmo sentido da necessidade de consignação dos recursos orçamentários para a realização da despesa. A Lei $n^{\circ}$ 4.320/64 veda a realização da despesa sem prévio empenho ${ }^{616}$ e condiciona a realização do empenho à existência de dotações orçamentárias ${ }^{617}$. Também o empenho se encontra na dependência da existência prévia de recursos orçamentários, visto que não se poderá exceder o limite dos créditos concedidos.

A Lei de Responsabilidade Fiscal também traz regras sobre o assunto. A criação, expansão ou aperfeiçoamento de ação governamental que acarrete aumento da despesa deverá ser acompanhada de estimativa do impacto orçamentário-financeiro e de declaração de adequação orçamentária e financeira com a LOA e de compatibilidade com o PPA e a $L D O^{618}$. Tais normas constituem, ainda, condição prévia para empenho e licitação de serviços, fornecimento de bens ou execução de obras ${ }^{619}$.

A adequação orçamentária com a LOA é aferida em razão da existência de dotação específica e suficiente, de modo que não se ultrapasse o limite estabelecido para o exercício $^{620}$. A compatibilidade do aumento da despesa com o PPA e a LDO é verificada em razão de sua conformidade com as diretrizes, objetivos, prioridades e metas previstos naqueles instrumentos e da não infringência a quaisquer de suas disposições ${ }^{621}$.

A geração de despesa obrigatória de caráter continuado, assim entendida como aquela decorrente de lei, medida provisória ou ato administrativo normativo que fixem

\footnotetext{
${ }^{615}$ JÈZE, Gaston. Principios Generales del Derecho Administrativo. Tomo IV. Traducción directa de la $3^{\text {a }}$ edición francesa, por Julio N. San Millán Almagro. Buenos Aires: Editorial Depalma, 1950, p. 19.

${ }^{616}$ Art. 60 da Lei $\mathrm{n}^{\circ} 4.320 / 64$.

${ }^{617}$ Art. 59 da Lei no ${ }^{\circ} .320 / 64$.

${ }^{618}$ Art. 16, I e II, LRF.

${ }^{619}$ Art. 16, § 4 ${ }^{\circ}$, I, LRF.

${ }^{620}$ Art. $16, \S 1^{\circ}$, I, LRF.

${ }^{621}$ Art. $16, \S 1^{\circ}$, II, LRF.
} 
para o ente a obrigação legal de sua execução por um período superior a dois exercícios deve ser acompanhada da comprovação de que não afetará as metas de resultados fiscais, além de seus efeitos financeiros serem compensados pelo aumento permanente de receita ou diminuição permanente de despesa ${ }^{622}$.

A despesa ou a assunção de obrigação que não atendam ao disposto nos arts. 16 e 17 da LRF são consideradas não autorizadas, irregulares e lesivas ao patrimônio público $^{623}$.

Deve-se ainda acrescentar a existência de dispositivos constitucionais que também determinam que outras leis e atos normativos observem a necessária previsão orçamentária. Exemplo notório é o art. 169 da Constituição Federal.

Segundo o texto constitucional, a concessão de qualquer vantagem ou aumento de remuneração, a criação de cargos, empregos e funções ou alteração de estrutura de carreiras, bem como a admissão ou contratação de pessoal, a qualquer título, pelos órgãos e entidades da administração direta ou indireta, inclusive fundações instituídas e mantidas pelo poder público só poderão ser feitas se houver prévia dotação orçamentária suficiente para atender às projeções de despesa de pessoal e aos acréscimos dela decorrentes e se houver autorização específica na lei de diretrizes orçamentárias ${ }^{624}$.

Como a criação de cargos, órgãos, tratamento da compensação remuneratória, são feitas por meio de leis, tais espécies normativas ficam submetidas à prévia autorização orçamentária.

A título de exemplo, a Lei $\mathrm{n}^{\circ}$ 11.877/08 dispôs sobre a criação de cargos efetivos e em comissão e funções comissionadas no quadro de pessoal do Tribunal Regional do Trabalho da $1^{\text {a }}$ Região, e previu, em seu art. $4^{\circ}$, parágrafo único, que "as alterações nos gastos com pessoal decorrentes desta Lei estão condicionadas à existência da respectiva autorização e dotação orçamentária".

Dessa forma, por expressa disposição constitucional - que integra e compõe o conteúdo e força vinculante da Lei de Orçamento - todas as leis versando sobre cargos e salários da Administração Pública ficarão condicionadas à específica previsão na LDO e à devida autorização orçamentária, por meio da previsão das necessárias dotações orçamentárias.

\footnotetext{
${ }^{622}$ Art. $17, \S 2^{\circ}$, LRF.

${ }^{623}$ Art. 15 LRF.

${ }^{624}$ Art. $169, \S 1^{\circ}$, I e II, CF/88.
} 


\subsection{Limites da atuação do Parlamento na discussão e aprovação do Orçamento}

O papel do Legislativo no processo de discussão, aprovação e controle da execução da Lei de Orçamento ocupa posição central no debate acerca da natureza jurídica da lei orçamentária. Efetivamente, a teoria da lei formal pode ser traduzida como uma tentativa deliberada de restringir os poderes enfeixados pelo Parlamento, conferindo-se ampla extensão às limitações impostas às Câmaras Legislativas no processo de alteração da Lei.

Em primeiro lugar, a elaboração do Orçamento não diria respeito às tarefas legislativas, figurando, com maior acerto, no âmbito das atribuições da Administração ${ }^{625}$. Do princípio estabelecido por Laband, de que a fixação do Orçamento é um ato administrativo que deve estar de acordo com a legislação, decorrem os limites jurídicopolíticos do direito do Legislativo de alterar, aprovar, bem como de não aprovar o Orçamento do Estado ${ }^{626}$.

A primeira limitação do Legislativo é a impossibilidade de suprimir dotações orçamentárias do projeto de lei que se encontrem relacionadas a obrigações civis do Estado $^{627}$. Dada a enormidade das obrigações do Estado, as faculdades do Parlamento seriam ilusórias em relação à maior parte do Orçamento. Além disso, para que o Poder Executivo obrigasse o Legislativo à aprovação de uma determinada dotação, bastaria a celebração de um contrato, com o que se tornaria impossível deixar de conceder a autorização orçamentária ${ }^{628}$.

Contudo, não somente as obrigações civis, notadamente decorrentes de contratos, vinculariam o Parlamento. Toda a lei válida que determinasse, direta ou indiretamente, quaisquer ingressos ou gastos, poderia ser traduzida como um óbice à livre deliberação parlamentar, constituindo-se em uma obrigação de direito público, tanto para o Governo quanto para o Parlamento ${ }^{629}$.

Para a correta delimitação da extensão dos poderes do Parlamento na supressão, redução ou aumento de dotações orçamentárias no projeto de lei, haveria que se dividir o Orçamento em dois setores conceituais: o que se encontrasse submetido e colmatado pelo Direito vigente e aquele outro que se encontrasse fora do mesmo ${ }^{630}$. Em outras palavras,

\footnotetext{
${ }^{625}$ LABAND, Paul. Derecho Presupuestario. Trad. Jose Zamit. Madrid: Instituto de Estudios Fiscales, 1979, p. 23.

${ }^{626}$ Ibid., p. 35.

${ }^{627}$ Ibid., p. 35 .

${ }^{628}$ Ibid., p. 60.

${ }^{629}$ Ibid., p. 36.

${ }^{630}$ Ibid., p. 36.
} 
Laband já antecipava que as faculdades enfeixadas pelo Legislativo difeririam conforme se tratasse de despesas constitucionais e/ou legais obrigatórias ou a despesas discricionárias. Na lição de Laband:

\begin{abstract}
En consecuencia, la Cámara baja no podrá suprimir los gastos derivados de contratos jurídico-civiles válidos, toda vez que sus decisiones no pueden liberar al Estado de obligaciones ya contraídas. Pero en los casos en que el Estado no esté obligado por el Derecho Civil a la prestación de un gasto, depende por completo de su albedrío hacer u omitir dicho gasto; en la decisión que tome al respecto podrá guiarse únicamente por consideraciones de conveniencia y, por ende, no existe ningún obstáculo jurídico para que la decisión correspondiente no pueda estar vinculada a la aprobación del Parlamento ${ }^{631}$.
\end{abstract}

O mesmo raciocínio poderia ser feito relativamente às receitas. Primeiramente, não haveria qualquer razão para que o Governo tolerasse aumento da estimativa de ingressos corretamente calculada na proposta orçamentária encaminhada ao Legislativo. Em segundo lugar, a supressão ou diminuição de dotações de receitas no Orçamento, pelo Legislativo, seria juridicamente nula, visto que tais receitas se encontrariam baseadas na legislação tributária em vigor. Nas palavras de Laband:

la fijación del Presupuesto es un acto administrativo que debe llevarse a cabo de acuerdo con las leyes; la supresión en el Presupuesto, por parte del Parlamento y sin el consentimiento del Gobierno, de un impuesto legalmente vigente, sería una violación de la ley, un acto nulo desde el punto de vista del Derecho público ${ }^{632}$.

Laband ainda destaca a existência de despesas decorrentes de leis que criaram diversas instituições, a exemplo de universidades, do Exército, de prisões, etc. Referida criação facultaria ao Governo a realização dos gastos que se revelassem necessários à sua conservação e manutenção ${ }^{633}$. Portanto, tais dispêndios se constituiriam em uma espécie de imperativo das leis do Estado, ostentando um fundamento jurídico-público ${ }^{634}$. Como consequência, o Parlamento não poderia se negar a autorizar os gastos necessários à manutenção dessas instituições ${ }^{635}$.

$\mathrm{Na}$ teoria labandiana, fica muito bem definido que o Legislativo não pode constranger o Executivo, por meio de limitações financeiras, a executar de forma imperfeita e insuficiente as leis existentes ${ }^{636}$.

\footnotetext{
${ }^{631}$ LABAND, Paul, op. cit., p. 58.

${ }^{632}$ Ibid., p. 39.

${ }^{633}$ Ibid., p. 59.

${ }^{634}$ Ibid., p. 58.

${ }^{635}$ Ibid., p. 61.

${ }^{636}$ Ibid., p. 68.
} 
Em síntese, a tese geral de Laband, relativamente às restrições a que se encontra submetido o Poder Legislativo no processo de discussão, alteração e votação do Orçamento é a seguinte:

el Parlamento sólo puede suprimir los gastos que no sean necesarios para la ejecución de las leyes y para el mantenimiento de las instituciones estatales existentes. (...) Esta regla no es directamente aplicable sino a una parte de los gastos anuales, a saber: de un lado, a aquellos gastos que indudable e incuestionablemente son discrecionales ${ }^{637}$.

A questão principal decorrente da separação das despesas decorrentes da lei e das despesas discricionárias será a definição de quais são os gastos que resultam necessários para a eficaz e adequada execução das leis ${ }^{638}$. Nos termos propostos por Laband, haveria uma zona cinzenta de que seriam exemplos a definição da quantidade de postos de trabalho, o valor das remunerações dos funcionarios, o número de autoridades e repartições administrativas:

\footnotetext{
Ahora bien, entre estos dos polos extremos se extiende una zona administrativa muy amplia, en la que, indudablemente, las leyes hacen necesarios unos gastos sin que, sin embargo, estén específicamente reglamentados el modo y manera de su aplicación ni la cuantia de las sumas monetarias que para ellos se requieren ${ }^{639}$.
}

Tal questão decorreria do fato de que existiriam, efetivamente, diversas maneiras de se organizar os postos de trabalho e cargos públicos, e com custos muito distintos, sem que se transgredisse as linhas fundamentais traçadas pela lei ${ }^{640}$. Todavia, também nesse caso, não assistiria ao Parlamento a faculdade de fixação unilateral das despesas que entendesse necessárias; deveria haver um acordo prévio entre Governo e Parlamento para tal decisão ${ }^{641}$. Laband enfatiza a natureza contratual desse acordo nos termos seguintes:

la naturaleza contractual se manifiesta en el hecho de que el acuerdo, una vez declarado y con validez jurídica, no puede ser rescindido unilateralmente por una de las partes. El acuerdo ya convenido entre el Gobierno y el Parlamento, al igual que el contrato en el ámbito del Derecho Civil, no puede ser anulado o modificado por disensión, sino sólo por contrarius consensus, es decir: por otro acuerdo distinto de voluntad ${ }^{642}$.

\footnotetext{
${ }^{637}$ LABAND, Paul, op. cit., p. 65.

${ }^{638}$ Ibid., p. 67.

${ }^{639}$ Ibid., p. 65.

${ }^{640}$ Ibid., p. 66.

${ }^{641}$ Ibid., p. 68.

${ }^{642}$ Ibid., p. 71.
} 
Por último, em face da criação de instituições permanentes, como tribunais judiciais e outros organismos, por meio da legislação própria, não há sentido na exigência de aprovação anual dos necessários recursos orçamentários, pelo Parlamento ${ }^{643}$. Diante disso, o Governo pode, na ampla maioria dos gastos, prescindir da aprovação da Lei de Orçamento pelo Legislativo.

Jèze segue, em linhas gerais, a concepção labandiana das restrições à atuação do Parlamento no processo de discussão, votação e aprovação da Lei de Orçamento. Para o jurista francês, com relação à maior parte dos gastos, a Lei de Orçamento, não possuiria qualquer significação jurídica. Esse seria o caso de dívidas existentes e de pensões concedidas: com relação a estas, o princípio do respeito aos direitos subjetivos se oporia a que o pagamento fosse, de qualquer maneira, impedido. Nessas hipóteses, portanto, o Parlamento se encontraria em face de um dever jurídico de incluir as dotações necessárias no Orçamento, sem qualquer apreciação discricionária ${ }^{644}$.

Por sua vez, com relação às despesas relativas ao funcionamento dos serviços públicos instituídos por leis, o Legislativo não poderia deixar de inscrever no Orçamento ou inscrever em montante insuficiente - as dotações necessárias à manutenção das instituições criadas $^{645}$.

Sobre o assunto, Aliomar Baleeiro se inclina em direção a tal corrente ao apresentar a classificação das despesas em gastos fixos e gastos variáveis. No que tange a despesas fixas, que resultam da execução da Constituição ou de leis, “O Presidente da República incorrerá em crime de responsabilidade se suspender a realização de tais dispêndios. $\mathrm{O}$ próprio Congresso está vinculado e não poderá evadir-se do dever de incluí-las no orçamento" $^{\text {646 }}$.

Em linhas gerais, de acordo com a teoria clássica do Orçamento, o Legislativo somente exercitaria a faculdade de alteração das composições orçamentárias no caso das despesas discricionárias, visto que, com relação àquelas decorrentes de leis ou demais obrigações do Estado, não haveria competência para qualquer modificação das dotações pelo Parlamento.

Antes de descer ao exame do tratamento conferido pelo direito positivo brasileiro, no que pertine à atuação do Poder Legislativo, confrontando-o com alguns dos argumentos

${ }^{643}$ LABAND, Paul, op. cit., p. 71/72.

644 JÈZE, Gaston. Cours de Science des Finances et de Législation Financière Française. Sixième Édition. Paris: Marcel Giard, 1922, p. 25/26.

${ }^{645}$ Ibid., p. 26.

${ }^{646}$ BALEEIRO, Aliomar. Uma Introdução à Ciência das Finanças. 12a ed. Rio de Janeiro: Forense, 1978, p. 426. 
utilizados pelos autores clássicos, cabe apontar alguns parâmetros normativos de outros países no que diz respeito aos poderes enfeixados pelo Legislativo.

No Chile, a Constituição delimita claramente a abrangência de atuação do Legislativo, relativamente à possibilidade de alteração do Orçamento: “(...) El Congreso Nacional no podrá aumentar ni disminuir la estimación de los ingresos; solo podrá reducir los gastos contenidos en el proyecto de Ley de Presupuestos, salvo los que estén establecidos por ley permanente (...)" 647 .

Dessa forma, os parâmetros constitucionais explicitam que o Parlamento não pode aumentar as despesas constantes do projeto de lei, mesmo as discricionárias. A estimativa das receitas não pode, de maneira alguma, ser alterada pelo Legislativo.

Em Portugal, a Assembléia da República detém poderes muito amplos para alterar a proposta orçamentária encaminhada pelo Executivo, podendo aumentar a despesa ou reduzir a receita, sem se encontrar vinculada a qualquer regra restritiva ${ }^{648}$. Todavia, há entendimentos no sentido de que as modificações orçamentárias deveriam, obrigatoriamente, compensar eventuais alterações, mantendo estabilizados o nível de déficit e de endividamento ${ }^{649}$. Além disso, no sistema orçamentário português, o Executivo não possui poderes para vetar a alteração orçamentária proposta pela Assembléia da República $^{650}$.

Na França, a Constituição também destaca as restrições do Parlamento na discussão e alteração da Lei de Orçamento, vedando a criação ou aumento de despesas pelo Legislativo, bem como a diminuição das receitas previstas: “Article 40. Les propositions et amendements formulés par les membres du Parlement ne sont pas recevables lorsque leur adoption aurait pour conséquence soit une diminution des ressources publiques, soit la création ou l'aggravation d'une charge publique". O Legislativo pode alterar a

\footnotetext{
${ }^{647}$ Art. 67 da Constituição do Chile.

${ }^{648}$ PORTUGAL. Ministério das Finanças e da Administração Pública. Direcção-Geral do Orçamento. Avaliação do Processo Orçamental em Portugal - Relatório da OCDE, p. 55. Disponível em: [http://www.dgo.pt/oe/OCDE2008/OCDE2008_AvaliacaoProcessoOrcamentalEmPortgual.pdf]. Acesso em 17.07.09. Texto originalmente publicado em língua inglesa pela OCDE com o título: Budgeting in Portugal por Teresa Curristine, Chung-Keun Park e Richard Emery, 2008.

${ }^{649}$ Conforme Canotilho e Vital Moreira, "Poderá porventura defender-se que, dada a relevância do equilíbrio orçamental e do nível da dívida pública por efeito do PEC da EU, as modificações orçamentais não deveriam poder agravar o défice previsto nem o nível de endividamento previstos na proposta governamental, sendo portanto obrigatório compensar as alterações com outras que mantenham o défice e o nível de endividamento de partida". CANOTILHO, J. J. Gomes; MOREIRA, Vital. Constituição da República Portuguesa Anotada. Vol. 1. $1^{\text {a }}$ ed. brasileira/4a ed. portuguesa. São Paulo: Revista dos Tribunais e Coimbra Editora, 2007, p. 1118.

${ }^{650}$ PORTUGAL. Ministério das Finanças e da Administração Pública. Direcção-Geral do Orçamento, op. cit., p. 56.
} 
composição do Orçamento das despesas, por meio de modificações de montantes alocados em programas ${ }^{651}$.

Além disso, caso o Parlamento propunha emendas o Primeiro Ministro poderá forçar a aprovação da sua versão de proposta de lei orçamentária, procedimento esse que somente poderá ser obstaculizado, no Parlamento, por meio da votação de uma moção de censura, com a consequente queda do Gabinete ${ }^{652}$.

No ordenamento brasileiro, a Constituição Federal de 1988, na Seção que cuida dos Orçamentos, erige os valores e parâmetros que fundamentam a atividade orçamentária. A princípio, cumpre realçar que o Legislador Constituinte teve por intenção o fortalecimento do papel e das funções conferidas ao Poder Legislativo. Não por outro motivo, espalha diversas regras constitucionais relativas ao Orçamento, submetendo todas as atividades do Poder Executivo, nessa matéria, ao crivo da fiscalização e controle parlamentares.

Ao vedar o início de programas ou projetos não incluídos na lei orçamentária, bem como a realização de despesas ou a assunção de obrigações diretas que excedessem os créditos orçamentários ou adicionais ${ }^{653}$, incumbiu o Poder Legislativo, por meio da aprovação e controle da Lei de Orçamento, da supervisão geral das atividades administrativas desenvolvidas pelo Executivo.

Em vários dispositivos, o texto constitucional manifesta a intenção de submeter as atividades desempenhadas pelo Executivo, no tocante à execução do Orçamento, à prévia autorização do Poder Legislativo.

Nesse sentido, veda-se a abertura de crédito suplementar ou especial sem prévia autorização legislativa ${ }^{654}$; a transposição, o remanejamento, ou a transferência de recursos de uma categoria de programação para outra ou de um órgão para outro, sem prévia autorização legislativa $^{655}$; a instituição de fundos de qualquer natureza, sem prévia autorização legislativa ${ }^{656}$; a utilização de recursos que, em decorrência de veto, emenda ou rejeição do projeto de LOA, ficarem sem despesas correspondentes, por meio de créditos especiais ou suplementares, sem prévia e específica autorização legislativa ${ }^{657}$.

\footnotetext{
${ }^{651}$ OECD Journal on Budgeting. Special Issue. The Legal Framework for Budget Systems - An Internacional Comparison. Vol. 4, nº 3, 2004, p. 201. Disponível em [http://www..oecd.org/dataoecd/48/48/35933542.pdf]. Acesso em 30.06.2009.

${ }^{652}$ Art. 49 da Constituição francesa.

${ }^{653}$ Art. 167, I e II, CF/88.

${ }^{654}$ Art. 167, V, CF/88.

${ }^{655}$ Art. 167, VI, CF/88.

${ }^{656}$ Art. 167, IX, CF/88.

${ }^{657}$ Art. $166, \S 8^{\circ}, \mathrm{CF} / 88$.
} 
A Carta Política de 1988 ainda veda a concessão de créditos orçamentários ilimitados ao Poder Executivo ${ }^{658}$, indicando a supremacia que cabe às Câmaras Legislativas, nesse tocante. Destarte, a palavra final, em termos de Orçamento, é do Poder Legislativo.

No que tange à faculdade de alteração do projeto de lei orçamentária, esta encontrase expressamente consignada na Constituição Federal, assim como as limitações existentes à atuação parlamentar relativas ao exercício do poder de emenda. Tais regras constitucionais constam do art. 166 da Constituição, nos termos seguintes:

\footnotetext{
Art. 166. (...)

$\S 3^{\circ}$ - As emendas ao projeto de lei do orçamento anual ou aos projetos que o modifiquem somente podem ser aprovadas caso:

I - sejam compatíveis com o plano plurianual e com a lei de diretrizes orçamentárias; II - indiquem os recursos necessários, admitidos apenas os provenientes de anulação de despesa, excluídas as que incidam sobre:

a) dotações para pessoal e seus encargos;

b) serviço da dívida;

c) transferências tributárias constitucionais para Estados, Municípios e Distrito Federal; ou

III - sejam relacionadas:

a) com a correção de erros ou omissões; ou

b) com os dispositivos do texto do projeto de lei.
}

O primeiro requisito que deve ser observado pelas emendas ao Orçamento é o da compatibilidade com as demais leis do ciclo orçamentário. Por isso, as emendas ao projeto de lei do orçamento anual ou aos projetos que o modifiquem somente podem ser aprovadas caso sejam compatíveis com o PPA e a LDO. No mesmo sentido, as emendas ao projeto de LDO somente podem ser aprovadas caso sejam compatíveis com o PPA ${ }^{659}$.

Ademais as emendas parlamentares devem indicar os recursos necessários, admitidos apenas os provenientes de anulação de despesa. Desta forma, os parlamentares poderiam anular despesas de uma categoria de programação e suplementar os montantes anulados em outras categorias, dando, assim, a medida de importância para determinados programas ou ações, em detrimento de outros.

Note-se que a expressão consignada, expressamente, pelo texto constitucional, diz respeito, apenas, aos recursos provenientes de anulação de despesa. Poder-se-ia admitir, portanto, que não existiria a possibilidade de se indicar como recursos aqueles oriundos de reestimativas de receitas, vedando-se ao Congresso Nacional modificar a composição das receitas previstas. Este é o entendimento esposado por Helio Tollini:

${ }^{658}$ Art. 167, VII, CF/88.
${ }^{659}$ Art. 166, $\S 4^{\circ}, \mathrm{CF} / 88$. 
o texto constitucional determina que acréscimos na programação de despesas por parte do Legislativo somente possam ser aprovados se houver cancelamento de valor equivalente nas despesas (art. 166, $\S 3^{\circ}$, inciso II: "admitidos apenas os provenientes de anulação de despesa", grifo nosso), de forma que o total das receitas estimadas e despesas fixadas no PLO não se altere. No entanto o Congresso Nacional, desde que recuperou suas prerrogativas constitucionais na área orçamentária, passou a utilizar-se de subterfúgio controverso para burlar a Constituição e reestimar as receitas constantes dos PLOs. Contrariando a norma específica acima referida, o Congresso interpreta que a norma geral "correção de erros ou omissões" (autorizada no art. 166, § $3^{\circ}$, inciso III, alínea $a$ ) aplica-se também à estimativa das receitas orçamentárias ${ }^{660}$

Efetivamente, a Constituição Federal também faculta ao Congresso Nacional a apresentação de emendas relacionadas com a correção de erros ou omissões ou com os dispositivos do texto do projeto de lei. A discussão, nesse caso, refere-se ao entendimento do Poder Legislativo de que reestimativas de receitas feitas pelo Congresso poderiam se enquadrar na hipótese de correção de erros ou omissões.

Cabe, portanto, a questão. Existe a possibilidade de que o Poder Executivo cometa erros ou omissões no processo de elaboração das estimativas de receita? Não se pode descartar, a priori, a possibilidade de que o Executivo cometa erros, nesse tocante. Em consequência, pode-se admitir como razoável a possibilidade de se corrigir erros ou omissões detectados, inclusive no que diz respeito à elaboração da receita.

Contudo, tal possibilidade há de ser fundamentada em prova robusta, para que a finalidade que inspira a norma se concretize por meio da estimativa de receita mais realista possível. Portanto, não se pode tolerar abusos na utilização do expediente, vedando-se reestimativas amplas e generalizadas das receitas, como mero artifício para se abrir espaço para o acomodamento das emendas parlamentares.

O $\$ 1^{\circ}$ do art. 12 da Lei de Responsabilidade Fiscal aponta para o entendimento aqui esposado, visto que expressamente dispõe que "reestimativa de receita por parte do Poder Legislativo só será admitida se comprovado erro ou omissão de ordem técnica ou legal". Esse dispositivo enfatiza a necessidade de sólida fundamentação que respalde o entendimento de erro na estimativa apresentada pelo Poder Executivo. Assim sendo, não há, nem na norma constitucional, nem no dispositivo infraconstitucional, espaço para crenças superficiais, sem suporte probatório considerável.

\footnotetext{
660 TOLLINI, Helio, op. cit., p. 10. Nesse sentido, Tollini advoga "O respeito ao espírito do texto constitucional relativo às finanças públicas, que não prevê a possibilidade de o Poder Legislativo reestimar as receitas constantes da proposta orçamentária encaminhada pelo Poder Executivo". Para mais detalhes sobre a discussão, ver a publicação já mencionada.
} 
A elaboração de emendas relativas ao texto do projeto de lei, por sua vez, faculta ao Legislativo exercer um controle muito importante acerca da normatização das autorizações para abertura de créditos suplementares e demais alterações da Lei de Orçamento. Por meio dessas emendas, o Congresso Nacional pode disciplinar as faculdades outorgadas ao Poder Executivo, para que o Orçamento seja executado fiel e eficientemente.

Retomando-se a análise das emendas provenientes de anulação da despesa, a Constituição Federal exclui, expressamente, três espécies de despesas, que não poderão ter suas dotações diminuídas, quais sejam: i) pessoal e encargos; ii) serviço da dívida; e iii) transferências constitucionais para os entes federativos.

Esses dispositivos representam óbices explicitamente mencionados pelo texto constitucional, de forma que o Poder Legislativo não poderá se utilizar de anulação de quaisquer destas espécies de despesas para suplementar outras categorias de programação.

Note-se que a Constituição da República, diferentemente da Constituição chilena, não faz qualquer menção a outras despesas obrigatórias estabelecidas pela legislação permanente. Diante disso, há que se empreender um esforço interpretativo, relativamente à intenção do Legislador Constituinte, igualmente das faculdades enfeixadas pelo Legislativo, nesse tocante.

Em tese, entende-se que não se trata de incluir ou de deixar de incluir, no Orçamento, as dotações para o pagamento de despesas decorrentes de obrigações constitucionais e/ou legais obrigatórias. Pode-se visualizar a questão da alteração da composição das dotações orçamentárias muito mais em termos de razoabilidade da estimativa elaborada.

As dotações, relativamente às despesas obrigatórias - constitucionais ou legais -, são meramente instrumentais e possuem um nítido cunho estimativo, visto que a realidade do caso concreto ditará a necessidade e extensão do volume de recursos necessários ao atendimento daquelas obrigações.

Além disso, tais obrigações representam vinculações não somente para o Legislativo, mas também para o Poder Executivo. Portanto, quanto mais realistas as previsões de gastos para o atendimento das obrigações constitucionais ou legais, melhor será o atendimento das demais programações da Lei de Orçamento.

Uma programação bem feita, portanto, é necessidade imperiosa para que outros programas não sofram, desnecessariamente, com a frustração no recebimento dos recursos 
orçamentários. Caso as dotações para as despesas obrigatórias revelem-se insuficientes, haverá exigência de cancelamento de outras programações, o que acarreta um efeito em cascata em toda a programação, prejudicando-a.

Dito isso, em princípio, deduz-se viável que o Poder Legislativo altere a composição de despesas, mesmo aquelas relativas a despesas obrigatórias, reforçando a programação que entender conveniente. Todavia, há que se utilizar dessa faculdade de forma criteriosa, haja vista que há consequências negativas que posteriormente poderão atrapalhar a execução de outros programas e ações.

Efetivamente, caso seja consignado um montante insuficiente para o cumprimento das obrigações da União, haverá necessidade de se suplementar o valor da dotação daquela despesa obrigatória e, consequentemente, será inevitávela anulação de despesa em outra programação, prejudicando outros programas e ações, que terão seus recursos parcialmente anulados.

Não se pode admitir, no ordenamento brasileiro, montantes notoriamente insuficientes tanto em relação a despesas obrigatórias quanto em relação aos demais programas e ações. Portanto, um dever jurídico, ao qual se encontram vinculados tanto o Poder Executivo quanto o Poder Legislativo, é, exatamente, o de consignarem dotações suficientes para o cumprimento dos fins a que se destinam.

À parte tal consideração, não se veda o remanejamento relativo a despesas obrigatórias, a não ser nos casos expressamente mencionados no texto constitucional, desde que se verifique a necessidade de suplementação em outra categoria de programação e que se entenda, com base em fundamentadas razões, que o valor inicialmente constante do projeto de lei encontra-se em excesso, podendo ser utilizado, parcialmente, em outro programa ou ação.

Com relação às dotações dos órgãos e instituições criados pelo Estado, seja por meio da própria Constituição, seja por meio de leis infraconstitucionais, há uma diferenciação que merece ser feita inicialmente, antes de se verificar a extensão da faculdade de alteração das dotações, pelo Legislativo.

Aos Poderes e órgãos aos quais a Constituição da República atribuiu autonomia orçamentária $^{661}$, observados os limites fixados na Lei de Diretrizes Orçamentárias quanto à

\footnotetext{
${ }^{661}$ Tal o que ocorre com o Poder Judiciário, o Ministério Público, as Defensorias Públicas. Para todos estes vale a regra insculpida nos capítulos constitucionais próprios, que assegura a elaboração de suas propostas orçamentárias dentro dos limites estabelecidos na lei de diretrizes orçamentárias (arts. $99, \S 1^{\circ}$; $127, \S 3^{\circ}$; $134, \S 2^{\circ}, \mathrm{CF} / 88$ ). Para uma análise mais pormenorizada dessa questão, em torno do Poder Judiciário, ver CONTI, José Maurício. A Autonomia Financeira do Poder Judiciário. São Paulo: MP Editora, 2006.
} 
elaboração de suas peças orçamentárias, não se encontram, nem o Poder Executivo, nem tampouco o Poder Legislativo, facultados a proceder a quaisquer alterações em suas composições orçamentárias, visto que tal invasão representaria violação do princípio da independência dos Poderes ou, no caso de órgãos destacados pelo texto constitucional, de infringência à autonomia orçamentária assegurada constitucionalmente.

Diverso, contudo, há de ser o tratamento das inúmeras instituições existentes dentro da máquina pública federal. Quanto a tais instituições, o único princípio que deve ser respeitado pelo Legislativo, bem como pelo Executivo, é o de assegurar os recursos necessários ao cumprimento dos fins a que se destinam os órgãos ou instituições criadas, sem o que se inviabilizaria a realização dos fins que ensejaram sua criação.

Todavia, dentro de um critério de razoabilidade, não há como se negar ao Legislativo a faculdade de escrutinar as receitas e despesas consignadas a tais órgãos, inclusive como forma de fiscalização das atividades desempenhadas, e, assim, de proceder a mudanças em sua composição orçamentária.

Outra limitação expressa, oriunda da Constituição Federal, é aquela relativa à obrigatoriedade de consignação, no Orçamento, das dotações necessárias ao pagamento dos débitos oriundos de sentenças judiciais. Nos termos do texto constitucional:

Art. $100 \S 1^{\circ}$ É obrigatória a inclusão, no orçamento das entidades de direito público, de verba necessária ao pagamento de seus débitos oriundos de sentenças transitadas em julgado, constantes de precatórios judiciários, apresentados até $1^{\circ}$ de julho, fazendo-se o pagamento até o final do exercício seguinte, quando terão seus valores atualizados monetariamente

Por conseguinte, há, expressamente, um dever, tanto do Poder Executivo quanto do Legislativo, relativamente à inclusão das dotações para pagamento de precatórios: o primeiro não pode deixar de incluir os montantes necessários no Orçamento, enquanto que o segundo não pode alterar a proposta orçamentária - feita adequadamente - para modificar o valor das dotações relativas aos precatórios. Nas palavras de Conti: "O Poder Legislativo, ao apreciar a proposta de orçamento, não pode alterá-la, no sentido de reduzir, anular, ou, de qualquer outra forma, adotar medida tendente a frustrar o pagamento dos precatórios" ${ }^{\prime 662}$.

Feitas tais considerações, cabe descer a um exame mais próximo do tratamento dado pelo Congresso brasileiro relativo ao regramento das emendas parlamentares.

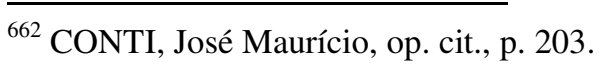


Em nosso sistema orçamentário, cabe à Comissão Mista de Planos, Orçamentos Públicos e Fiscalização - CMO examinar e emitir parecer sobre os projetos de LOA, LDO e $\mathrm{PPA}^{663}$. Emendas aos referidos projetos devem ser apresentadas a esta Comissão, que também sobre elas emitirá parecer, sendo posteriormente encaminhadas para apreciação pelo Plenário do Congresso Nacional, na forma prevista pelo regimento ${ }^{664}$.

A Resolução $\mathrm{n}^{\circ}$ 1/2006-CN dispõe sobre o funcionamento da CMO, bem como sobre a tramitação das matérias relativas às leis orçamentárias, inclusive estabelecendo o regramento básico relativo às emendas parlamentares. Existem quatro comitês permanentes integrando a composição da CMO: i) Comitê de Avaliação, Fiscalização e Controle da Execução Orçamentária; ii) Comitê de Avaliação da Receita; iii) Comitê de Avaliação das Informações sobre Obras e Serviços com Indícios de Irregularidades Graves; e iv) Comitê de Exame da Admissibilidade de Emendas.

As emendas parlamentares podem ser classificadas sob diferentes perspectivas, conforme o objeto de análise. A principal classificação é a que divide as emendas em emendas de receita e emendas de despesa, conforme tenham por objeto, respectivamente, a fonte de recursos que faculta sua aplicação, receita, ou a aplicação de determinado recurso com vistas ao alcance de determinado fim, despesa.

São emendas de receita as que têm por finalidade alteração da estimativa da receita, inclusive as que propõem redução dessa estimativa ${ }^{665}$. As compensações na despesa decorrentes da aprovação de emenda que acarrete redução de receita ficarão a cargo do Relator-Geral $^{666}$.

As emendas de despesa são aquelas que alteram a aplicação de recursos constante do projeto de Lei de Orçamento, e podem ser subdivididas em três espécies: de remanejamento, de apropriação ou de cancelamento ${ }^{667}$.

Emenda de remanejamento é a que propõe acréscimo ou inclusão de dotações e, simultaneamente, como fonte exclusiva de recursos, a anulação equivalente de dotações constantes do projeto, exceto as da Reserva de Contingência ${ }^{668}$.

Emenda de apropriação é a que propõe acréscimo ou inclusão de dotações e, simultaneamente, como fonte de recursos, a anulação equivalente de: i) recursos

\footnotetext{
${ }^{663}$ Art. $166, \S 1^{\circ}, \mathrm{I}, \mathrm{CF} / 88$.

${ }^{664}$ Art. $166, \S 2^{\circ}, \mathrm{CF} / 88$.

${ }^{665}$ Art. 31, caput, da Resolução no $1 / 2006-\mathrm{CN}$.

${ }^{666}$ Art. 31, parágrafo único, da Resolução n ${ }^{\circ} 1 / 2006-\mathrm{CN}$.

${ }^{667}$ Art. 37 da Resolução no 1/2006-CN.

${ }^{668}$ Art. 38, caput, da Resolução n ${ }^{\circ}$ 1/2006-CN.
} 
integrantes da Reserva de Recursos a que se refere o art. 56; e ii) outras dotações, definidas no Parecer Preliminar ${ }^{669}$.

Por sua vez, emenda de cancelamento é a que propõe, exclusivamente, a redução de dotações constantes do projeto ${ }^{670}$.

Considerando a iniciativa parlamentar que lhes dá origem, as emendas parlamentares poderão ser de três espécies: i) Emendas de Comissão; ii) Emendas de Bancada Estadual; e iii) Emendas Individuais.

As Emendas de Comissão são aquelas apresentadas pelas Comissões Permanentes do Senado Federal e da Câmara dos Deputados ${ }^{671}$ e possuem, como requisitos, o caráter institucional e a representação de interesse nacional ${ }^{672}$. Há limitações quanto à quantidade de emendas passíveis de serem apresentadas ${ }^{673}$.

As Emendas de Bancada Estadual são aquelas apresentadas pelas Bancadas Estaduais no Congresso Nacional, relativas a matérias de interesse de cada Estado ou Distrito Federal ${ }^{674}$. Há uma séria de requisitos exigidos para a apresentação dessas emendas na Resolução do Congresso ${ }^{675}$, bem como limites relativos à quantidade de emendas dessa espécie que podem ser apresentadas.

A seu turno, as Emendas Individuais se originam da atuação individual do membro do Poder Legislativo, que pode apresentar até 25 ao projeto, cabendo ao parecer preliminar fixar o valor total do conjunto de emendas a serem apresentadas, por mandato parlamentar $^{676}$.

Em conformidade à espécie de proposição legislativa a que se refiram, as emendas poderão ser de Projeto de Lei Orçamentária Anual - PLOA, de projeto de lei de créditos adicionais, ou, ainda, relativas à medida provisória apresentada, isto é, crédito extraordinário.

As emendas ao PLOA se constituem na modalidade ordinária de intervenção do Legislativo no processo do ciclo orçamentário. As emendas aos projetos de lei de créditos adicionais $^{677}$ são limitadas a até dez emendas por parlamentar e devem preencher os requisitos fixados na Resolução. Por sua vez, as emendas aos créditos extraordinários

\footnotetext{
${ }^{669}$ Art. 39, I e II, da Resolução n ${ }^{\text {o } 1 / 2006-C N . ~}$

${ }^{670}$ Art. 40 da Resolução no 1/2006-CN.

${ }^{671}$ Art. 43 da Resolução no 1/2006-CN.

${ }^{672}$ Art. 44, II, da Resolução no 1/2006-CN.

${ }^{673}$ Art. 44, § 1 ${ }^{\circ}$, I e II, da Resolução n $1 / 2006-C N$.

${ }^{674}$ Art. 46 da Resolução no 1/2006-CN.

${ }^{675}$ Art. 47 da Resolução no 1/2006-CN.

${ }^{676}$ Art. 49 da Resolução no 1/2006-CN.

${ }^{677}$ Art. 108 da Resolução n ${ }^{\circ}$ 1/2006-CN.
} 
abertos por medida provisória somente serão admitidas com a finalidade de modificar o texto da medida provisória ou de suprimir dotação, total ou parcialmente ${ }^{678}$.

Essas são, em breves linhas, as limitações a que se encontra submetido o Poder Legislativo, em nosso ordenamento jurídico, relativamente à extensão de suas faculdades de alteração do projeto de lei orçamentária. Cabe, nesse contexto, tecer algumas comparações com a argumentação utilizada pela teoria clássica.

Em apertada síntese, as alegações utilizadas pela teoria clássica, notadamente Laband, são as seguintes: i) o Parlamento encontra-se impossibilitado de suprimir dotações relativas a obrigações civis; ii) o aumento ou diminuição de receitas, pelo Parlamento, são juridicamente nulos; iii) as despesas determinadas diretamente pela lei não podem ser suprimidas do Orçamento; iv) os gastos indiretos decorrentes de lei (a exemplo das instituições criadas) não podem ser diminuídos, de forma a se executar imperfeitamente as leis existentes ou a impedir o funcionamento das instituições; e v) o Parlamento somente pode alterar a composição das despesas discricionárias.

No ordenamento jurídico brasileiro, como visto, há várias objeções que podem ser levantadas de forma contrária às alegações utilizadas pela teoria clássica. De forma sintética, podem ser condensadas as seguintes ponderações aos pontos principais destacados pelos autores clássicos:

i) em nosso sistema orçamentário, são as obrigações a serem criadas pelo Estado que devem encontrar amparo na Lei de Orçamento, sem o que nascem irregulares e viciadas; ademais o pagamento de despesas sem previsão orçamentária não poderá ser realizado, a teor do que prevê o art. 167, II, da Constituição Federal;

ii) entende-se cabível a reestimativa de receitas pelo Parlamento, desde que amparada em fundamentação sólida e transparente quanto aos motivos ensejadores dos erros ou omissões encontrados;

iii) as despesas obrigatórias são consignadas na Lei de Orçamento enquanto estimativas; portanto, tanto o Poder Executivo quanto o Poder Legislativo se encontram no dever jurídico de aproximarem tais estimativas da realidade; isso não impede, contudo, que possam ser realizados remanejamentos, de acordo com as previsões efetuadas, à exceção das vedações expressamente consignadas no texto constitucional (pessoal e encargos; dívida pública; e transferências constitucionais obrigatórias aos entes federativos);

${ }^{678}$ Art. 111 da Resolução no $1 / 2006-C N$. 
iv) a única restrição a que se encontra submetido o Poder Legislativo, no tocante à alteração da composição das dotações orçamentárias consignadas a órgãos da máquina estatal federal, é a de se permitir o razoável desenvolvimento das funções a que se prestam referidas instituições; nesse sentido, veda-se ao Legislativo a consignação de recursos monetários notoriamente insuficientes para o cumprimento dos fins a que se destinam os órgãos; nesse ponto, assiste razão, em linhas gerais, à argumentação desenvolvida pelos autores da teoria clássica de Orçamento, com a diferença de que não existe acordo prévio que vincula o Legislativo: o próprio Orçamento há de ser considerada a esfera em que será construído o acordo entre Executivo e Legislativo, relativamente à priorização a ser conferida a certos órgãos ou programas, em detrimento de outros; e

v) a liberdade de alteração da composição das despesas discricionárias pelo Parlamento é, sem dúvida, mais ampla do que aquela relativa às despesas obrigatórias e enseja maior faculdade de modificação das dotações do projeto; tal fato não impede, contudo, a possibilidade de alteração mesmo de dotações de despesas obrigatórias, dentro de um critério de razoabilidade.

Cabe ainda salientar que, no sistema orçamentário brasileiro, o Poder Legislativo está munido de maiores atribuições e faculdades no processo de discussão, alteração e votação da Lei de Orçamento, do que em outros países. As restrições a que se encontra submetido o Legislativo na França e no Chile, por exemplo, são maiores do que aquelas encontradas em nosso regime. Em termos comparativos, poderíamos afirmar que a situação do Congresso estaria mais assemelhada, quanto à faculdade de alteração do projeto de lei, com o sistema português.

Por último, cabem algumas reflexões levantadas, no direito comparado, a respeito da discussão dos poderes enfeixados pelo Legislativo no processo de discussão, alteração e votação da Lei de Orçamento.

Canotilho questiona a premissa assentada pela teoria clássica de Orçamento, no sentido de que seria ilegítima a possibilidade da recusa do projeto de lei de orçamento pelo Legislativo. Em suas palavras:

Mesmo que não se conteste a existência de vínculos jurídicos preexistentes (vínculos derivados da Constituição, das leis gerais de contabilidade, das leis materiais de despesas e receitas), estes vínculos não podem traduzir-se num confisco da liberdade de apreciação do Parlamento. Se a assembleia representativa não pudesse recusar a aprovação do orçamento, isso acarretaria uma notória perturbação do sistema de equilíbrio de poderes, com o consequente quase-monopólio do Governo no âmbito dos planos financeiros. O Parlamento tem o dever de apreciar o orçamento mas não a obrigação de o aprovar. Até porque, a invocada paralisia do estado pode ser sempre 
superada pela prática de exercícios provisórios ou, na falta de lei que regule expressamente a situação, sempre se chegaria à ideia de estado de necessidade nos termos gerais de direito ${ }^{679}$.

Além disso, Canotilho elabora ampla análise, confrontando os aspectos destacados pela teoria da lei formal com uma visão mais ampla e abrangente da Lei de Orçamento e da função do Legislativo nesse processo:

Problema diferente é o de saber se, além da possibilidade de recusa, será admissível a introdução de alterações, por parte do Parlamento, ao projecto do orçamento apresentado pelo Governo. A solução para o problema em análise dependerá, em grande parte, da disciplina constitucional e legal vigente nos ordenamentos positivos. Em alguns ordenamentos, sob o influxo da teoria da lei formal, restringe-se a intervenção das assembleias representativas à autorização ou recusa da cobrança de receitas e efectivação de despesas; noutros, mais consentâneos com a ideia de lei de orçamento como lei material e com a ideia de participação do Parlamento na fixação do plano orçamental, não se impede que os deputados proponham e aprovem alterações ao projecto de lei do orçamento. Subjacente à primeira solução está ainda a ideia de que o orçamento é um acto próprio do poder executivo, não havendo qualquer competência material do Parlamento na determinação do conteúdo do acto. Logicamente que se o acto é um acto da competência reservada do executivo, ao Parlamento outra solução não restaria senão a aprovação ou recusa em bloco do orçamento. A esta solução, ancorada na ideia do que a intervenção parlamentar é um acto de controlo político e não um acto materialmente legislativo, outra se pode opor e que é a de conceber a participação da assembleia representativa como uma intervenção normal na feitura das leis que, não obstante certas especificidades, tem os efeitos jurídicos típicos de qualquer acto legislativo. Isto justificaria não apenas a possibilidade de introdução de alterações ao projecto do Governo, mas ainda a possibilidade de, através da própria lei do orçamento, se modificarem ou até revogarem as leis materiais existentes ${ }^{600}$.

Em síntese, a visão que procura se contrapor à decantada teoria da lei formal destaca o papel ativo do Legislativo na elaboração da Lei de Orçamento enquanto atividade principal do Parlamento no sentido de imprimir uma determinada condução do Governo:

A aprovação parlamentar da lei do orçamento representa sempre a adesão a um acto de direcção política fundamental, em que o Parlamento se vê associado à tarefa de corporizar, aprovando o orçamento, um 'impulso' político autônomo, assumindo ou não as opções políticas do Governo, ao mais alto nível de decisão dos órgãos do Estado e revestindo enquanto tal o conteúdo verdadeiramente substancial de uma lei ${ }^{681}$.

Na mesma linha de análise segue Fonrouge:

${ }^{679}$ CANOTILHO, José Joaquim Gomes. A Lei do Orçamento. In Estudos em Homenagem ao Prof. Doutor J. J. Teixeira Ribeiro. Universidade de Coimbra: Boletim da Faculdade de Direito, Número Especial, 1979, p. 556.

${ }^{680}$ Ibid., p. 557/558.

${ }^{681}$ MONCADA, Luís S. Cabral de. Perspectivas do Novo Direito Orçamental Português. In: Estudos de Direito Público. Coimbra Editora, 2001, p. 92/93. 
(...) La función legislativa, en nuestro país, no se reduce a 'aprobar' o 'autorizar' lo que propone el ejecutivo, pues es ejercitada en toda su plenitud. Las Cámaras no reciben un acto concluido o definitivo, sino un proyecto de presupuesto a considerar, como puede ocurrir con cualquier otra materia; el ejecutivo coparticipando en la acción de gobierno, sugiere o propone una ley, y el legislativo la hace suya, la rechaza o la modifica, total o parcialmente, sin existir límites constitucionales a su libre albedrío. Se trata, pues, de una ley normal, no de un acto aprobatorio que pasa a integrar un acto administrativo, debiendo rechazarse el concepto de que es ley de 'aprobación' o de 'autorización'.

(...) La acción parlamentaria es normal y no excepcional; primordial y básica, no secundaria; originaria y no derivada o subordinada. En los sistemas en que el presupuesto incluye la creación de tributos, no hay simple consentimiento legislativo $(\ldots)^{682}$.

Quanto às limitações, Fonrouge salienta que, à exceção das limitações constitucionais, a apreciação do Legislativo é ampla: "no existen limitaciones a la acción del poder legislativo, salvo las que puedan resultar de los derechos y garantías esenciales asegurados por la Constitución, cuya apreciación está librada, entre nosotros, al poder judicial"683.

Sainz de Bujanda também ensina que:

Puesto que la aprobación del Presupuesto constituye una manifestación normal y no excepcional de la función legislativa (como ejercicio de un auténtico poder normativo creador), la Ley de Presupuestos puede contener normas jurídicas que creen o modifiquen el derecho objetivo preexistente. La Ley de Presupuestos no puede considerarse, por tanto, como un ejemplo típico de 'legislación vinculada', como sostienen los defensores de la ley formal ${ }^{684}$.

Existe, pois, toda uma linha teórica de origem diversa que ressalta a função exercida pelo Legislativo no processo de discussão, alteração, votação e aprovação da Lei de Orçamento como uma atividade essencial do Estado Democrático. Tal visão, ainda que considere relevantes os argumentos apresentados pela teoria clássica, incorpora outros elementos que não podem ser desconsiderados no exame da natureza jurídica do mais importante diploma infraconstitucional dos Estados Modernos.

${ }^{682}$ FONROUGE, Carlos M. Giuliani. Derecho Financiero. Vol. I. $3^{\text {a }}$ ed. Buenos Aires: Depalma, 1977, p. $141 / 142$.

${ }^{683}$ Ibid., p. 143.

${ }^{684}$ SAINZ DE BUJANDA, Fernando. Lecciones de Derecho Financiero. $7^{\mathrm{a}}$ ed. Madrid: Universidad Complutense, 1989, p. 439/440. 


\subsection{Infrações à Lei de Orçamento e sua responsabilização}

Os teóricos clássicos da Lei de Orçamento, como Laband e Jèze, não se furtaram ao exame da delimitação das violações à lei orçamentária, bem como das consequências jurídicas advindas. Ao contrário, no bojo de suas construções dogmáticas enfrentaram a questão, procurando reforçar o entendimento do caráter meramente formal da Lei de Orçamento.

Laband indica quatro hipóteses que deveriam ser consideradas violações à lei orçamentária, para que essa possuísse autêntica força de lei: i) gastos adicionais ou superiores àqueles consignados; ii) gastos inferiores aos previstos; iii) diminuição ou queda de arrecadação; e iv) excesso de arrecadação. Em suas palavras:

Si se quiere conferir a la ley presupuestaria auténtica fuerza de ley, en el sentido corriente de esta expresión, habría que declarar infracciones legales todas las desviaciones con respecto al Presupuesto, o sea: no solamente los gastos adicionales, sino también los ahorros de gastos, las reducciones de ingresos y los excesos de ingresos $^{685}$.

O entendimento de que a mensuração do grau de cumprimento da Lei de Orçamento se daria pela proximidade formal entre os valores previstos e os valores executados, encontra-se na base do desenvolvimento teórico de então. Nesse contexto, o Parlamento prussiano, procurando enfatizar seu poder no processo orçamentário, advogava a vinculação do Executivo aos montantes consignados na Lei, tal como aprovada:

Con arreglo a una idea, reiterada y consecuentemente postulada por la Cámara de Diputados prusiana, es vinculante para el Gobierno toda partida presupuestaria concreta tal como se haya incluido en el proyecto de Presupuesto presentado a la Cámara y haya sido aprobada por ésta, o sea, son vinculantes todos los detalles y pormenores del llamado Presupuesto administrativo; el Gobierno no puede sobrepasar en ninguno de los gastos la suma presupuestada, ni siquiera en el caso de que en otros gastos se hayan hecho unos ahorros equivalentes en su cuantía, a menos que la misma ley presupuestaria haya autorizado una transferencia de esta naturaleza ${ }^{686}$.

Laband concorda que a eficácia jurídica do Orçamento deveria se estender a todos os créditos orçamentários ${ }^{687}$, contudo, em atenção ao desenvolvimento de sua teoria,

\footnotetext{
${ }^{685}$ LABAND, Paul. Derecho Presupuestario. Trad. Jose Zamit. Madrid: Instituto de Estudios Fiscales, 1979, p. 90.

${ }^{686}$ LABAND, Paul, op. cit., p. 97.

${ }^{687}$ Ibid., p. 100.
} 
termina por afirmar que a infração à Lei de Orçamento não enseja qualquer consequência jurídica efetiva:

Por consiguiente, el Parlamento ha de limitarse única y exclusivamente a negar la autorización de las infracciones presupuestarias y de los gastos extrapresupuestarios y a rechazar el descargo del Gobierno. Es posible que la no concesión del descargo le resulte inoportuna al Gobierno; pero está fuera de toda duda que ello no acarrea consecuencias prácticas de ninguna especie y que, en último término, tal vez el ministerio se acostumbre a prescindir del descargo otorgado por el Parlamento o del otorgado por una de las dos Cámaras que lo componen ${ }^{688}$.

Em outros termos, de acordo com tal linha teórica, a única consequência do descumprimento da Lei de Orçamento é que "el Gobierno está obligado a pedir la aprobación del Parlamento para todas las infracciones presupuestarias y para todos los gastos extrapresupuestarios" ${ }^{\text {689 }}$. No entanto, como a falta de aprovação das contas do Governo pelo Parlamento não acarreta consequências práticas, não há que se falar em qualquer espécie de sanção.

Ademais, no texto constitucional prussiano não se encontrava previsto qualquer dispositivo que indicasse a possibilidade de haver alguma responsabilização pelas violações à Lei de Orçamento:

Si una futura ley de responsabilidades de los ministros hiciera responsables a éstos, con carácter general, de las infracciones presupuestarias, para lo cual se podrían invocar razones de naturaleza política, es indudable que implicaría una modificación de la Constitución. Pero en tanto no se promulgue la ley de responsabilidades de los ministros, prometida en el art. 61 de la Ley Constitucional, la pretendida responsabilidad de éstos seguirá siendo completamente ilusoria ${ }^{690}$.

Por último, no ordenamento jurídico prussiano não existiriam mecanismos aptos a asegurar a responsabilização daqueles que infringissem a lei orçamentária:

Muchísimo más deficiente todavía es la situación jurídica en Prusia por lo que toca al segundo aspecto, a saber: a los instrumentos de que dispone el Parlamento para demandar a los ministros por incumplimiento del Presupuesto. Hay una triple responsabilidad a la que pueden estar sujetos los ministros: la de Derecho Público, la de Derecho Civil y la general de Derecho Penal. El Parlamento no está facultado para pedir ninguna de ellas.

La responsabilidad jurídico-pública de los ministros frente al Parlamento está regulada en el artículo 61 de la Ley Constitucional. En él se restringe el derecho de acusación de las Cámaras a los tres casos 'delictivos de violación de la Constitución, soborno y traición'. No se cita la infracción del Presupuesto ni la verificación de gastos extrapresupuestarios. En las sesiones parlamentarias, desde luego, se ha solido subsumir

${ }^{688}$ LABAND, Paul, op. cit., p. 115.

${ }^{689}$ Ibid., p. 105.

${ }^{690}$ Ibid., p. 113. 
estas acciones en el concepto de 'violación de la Constitución'; pero, aunque haya de admitirse que puede haber casos en los que la realización de gastos se calificaría como violación del art. 99 de la Ley Constitucional, es innegable que declarar con carácter general como violación de la Constitución la realización de todo gasto que no esté previsto en el Presupuesto, o su realización en una cuantia superior a la prevista, se opone intrínsecamente tanto al auténtico concepto de ley presupuestaria como a las reglas de la interpretación lógica ${ }^{691}$.

Jèze desenvolve teoria muito semelhante à de Laband, relativamente às consequências advindas das infrações orçamentárias. Para o jurista francês, a autorização parlamentar, ou seja, o crédito orçamentário, somente vale para o objeto especificado no respectivo crédito, em observância à regra da especialidade orçamentária ${ }^{692}$, dentro dos limites máximos de gasto disponíveis ${ }^{693}$ e de certo período de tempo ${ }^{694}$. Todavia, segundo esse jurista não há qualquer consequência jurídica para o descumprimento das regras enunciadas $^{695}$.

Feitas as devidas digressões em torno da abordagem conferida ao tema pela teoria clássica, imprescindível que se examine o tratamento dado pelo ordenamento jurídico brasileiro relativamente à possibilidade de se demandar os infratores da Lei de Orçamento. Posteriormente, há que se evidenciar qual o significado, extensão e contornos das infrações ao Orçamento, para que se torne possível verificar em que medida haverá responsabilização pelo descumprimento da Lei Orçamentária.

Em primeiro lugar, existem dois elementos estruturantes centrais que conformam a constituição ou o delineamento orgânico da Lei de Orçamento em nosso ordenamento:i) $o$ conteúdo da Lei de Orçamento é central e diretamente constitucional; e ii) a Lei de Orçamento não pode conter matéria estranha àquela atribuída pela Constituição da República.

Quando se diz que o conteúdo da Lei de Orçamento é centralmente constitucional, refere-se ao fato de que, em nosso ordenamento, houve por bem o Legislador Constituinte tratar diretamente da maior parte desse conteúdo, em face da relevância de que se reveste a lei orçamentária. Tal matéria encontra-se espalhada pelos dispositivos do art. 165 da

\footnotetext{
${ }^{691}$ LABAND, Paul, op. cit., p. 113.

${ }^{692}$ JÈZE, Gaston. Principios Generales del Derecho Administrativo. Tomo IV. Traducción directa de la $3^{\text {a }}$ edición francesa, por Julio N. San Millán Almagro. Buenos Aires: Editorial Depalma, 1950, p. 16.

${ }^{693}$ Ibid., p. 16.

${ }^{694}$ Ibid., p. 17.

${ }^{695}$ Ibid., p. 18/23.
} 
Constituição Federal ${ }^{696}$, muito embora não se restrinja à Seção II (Dos Orçamentos) do Capítulo II (Das Finanças Públicas) do Título VI (Da Tributação e do Orçamento).

Efetivamente, há regras que integram seu conteúdo, além de oferecer relevantes parâmetros para sua análise, na Seção IX ( $D a$ Fiscalização Contábil, Financeira e Orçamentária) do Capítulo I (Do Poder Legislativo) e na Seção III (Da Responsabilidade do Presidente da República) do Capítulo II (Do Poder Executivo), ambas integrantes do Título IV (Da Organização dos Poderes) da Constituição de 1988.

Uma dessas regras - e de particular importância - é exatamente a que incorpora ao conteúdo da Lei de Orçamento a sanção ensejada pela sua violação. Nesse sentido, reza o art. 85 da Constituição da República que:

Art. 85. São crimes de responsabilidade os atos do Presidente da República que atentem contra a Constituição Federal e, especialmente, contra:

VI - a lei orçamentária;

Parágrafo único. Esses crimes serão definidos em lei especial, que estabelecerá as normas de processo e julgamento.

Precisamente por ser a Lei de Orçamento o mais importante dos diplomas normativos infraconstitucionais, houve por bem a Constituição da República tratar como crime de responsabilidade as infrações que lhe forem desfechadas ${ }^{697}$.

Nesse dispositivo fica assentado, portanto, que a violação da lei orçamentária pode ser caracterizada como crime de responsabilidade, ensejando a aplicação de determinada sanção àquele que exerce a direção superior da administração federal ${ }^{698}$, ou seja, ao Presidente da República.

Contudo, muito embora a sanção decorra dos contornos constitucionais que oferece a Constituição de 1988 à Lei de Orçamento, a regulamentação dessa mesma sanção não poderá ser efetuada por meio dos dispositivos da peça orçamentária e isso por duas razões principais.

\footnotetext{
${ }^{696}$ A estruturação basilar encontra-se no art. $165, \S 5^{\circ}$, que assevera que a lei orçamentária anual compreenderá o orçamento fiscal, o orçamento de investimento das empresas e o orçamento da seguridade social. Todavia, o conteúdo da Lei de Orçamento está muito longe de se restringir a essa composição, como analisado, de forma sistemática, na Seção 4.3 e Subseção 4.5.3, ambas deste capítulo, em que destacamos como seus elementos constituintes centrais os objetivos e metas. Tal conteúdo é ainda acrescido e integrado por elementos contidos em outros dispositivos, a exemplo do parágrafo $6^{\circ}$, que acrescenta o demonstrativo regionalizado do efeito das isenções e outras formas de renúncia fiscal e do parágrafo $8^{\circ}$, que acrescenta a autorização para abertura de créditos suplementares e contratação de operações de crédito.

${ }^{697}$ BRITTO, Carlos Ayres. O Regime Constitucional dos Tribunais de Contas. In: O Novo Tribunal de Contas - Órgão Protetor dos Direitos Fundamentais. Belo Horizonte: Fórum, 2005, p. 64.

${ }^{698}$ Art. 84, II, CF/88.
} 
A primeira delas nos remete ao segundo elemento a que se fez referência anteriormente, qual seja, o de que a Lei de Orçamento não pode tratar de conteúdo estranho àquele atribuído pela Constituição da República. Esse elemento estruturante empresta peculiaridade aos contornos constitucionais da lei orçamentária, encontrando-se estampado no $\S 8^{\circ}$ do art. 165 , in verbis:

$\S 8^{\circ}$ - A lei orçamentária anual não conterá dispositivo estranho à previsão da receita e à fixação da despesa, não se incluindo na proibição a autorização para abertura de créditos suplementares e contratação de operações de crédito, ainda que por antecipação de receita, nos termos da lei.

Portanto, uma vez que a Lei de Orçamento possui conteúdo de extração diretamente constitucional, ao qual se encontra vinculada, no sentido de que não poderá tratar de matéria diversa daquela que lhe foi outorgada, a lei orçamentária fica proibida de normatizar sanções ou infringências aos seus próprios dispositivos.

A segunda razão decorre da menção explícita do texto constitucional, que determina que os crimes de responsabilidade deverão ser definidos em lei especial. E o objetivo visado pelo Constituinte, ao atribuir à legislação permanente a definição de crimes da envergadura dos crimes de responsabilidade, encontra-se relacionado à estabilidade e segurança que se pretendeu conferir a uma legislação punitiva dessa ordem. Quanto a isso, a vigência temporária e anual da Lei de Orçamento não poderia contribuir com a estabilidade e durabilidade pretendidas nesse contexto.

Dessa forma, existe uma incompatibilidade apenas aparente no fato de haver sanção à Lei de Orçamento e no de que tal sanção não pode ser regulamentada por meio de seus próprios dispositivos, em atenção à observância de regras constitucionais explícitas que outorgaram um conteúdo próprio e peculiar à lei orçamentária.

Em síntese, o núcleo sancionatório da Lei Orçamentária é depreendido do texto constitucional, embora seja integrado por meio de edição de leis específicas que suprirão a impossibilidade de a própria lei orçamentária dar o tratamento às vedações de seus dispositivos. Em face disso, as infrações à Lei de Orçamento são sancionadas por meio de dispositivos que, embora não integrem formalmente a peça orçamentária, representam uma espécie de extensão ou complementação de seu corpo normativo, reforçando-lhe a eficácia.

Há que se registrar, nesse contexto, que a origem dessa sua característica, que à primeira vista pode parecer enfraquecer o tônus jurídico da Lei de Orçamento, representa, sob um olhar mais cuidadoso, a segurança de que sua função primordial não será 
desvirtuada. Efetivamente, as caudas orçamentárias representavam - não somente no Brasil, diga-se de passagem - um fenômeno de generalizada ocorrência, visto que, aproveitando-se de sua tramitação especial e de seu rito próprio, inseriam-se dispositivos os mais diversos, corrompendo-se sua finalidade essencial de condução dos negócios do Estado para o exercício financeiro subsequente. Tal o motivo ensejador da vedação material que lhe conferiu o texto constitucional.

Feitas tais considerações introdutórias a respeito do modelo organizador da Lei de Orçamento, há que se indagar se a única sanção consignada na Constituição da República para o descumprimento da Lei de Orçamento seria a de aplicação da pena prevista para o crime de responsabilidade. E, de antemão, destacamos que absolutamente não, visto que o texto constitucional deixa assentada a existência de outras sanções para as violações perpetradas contra a Lei de Orçamento. Para tanto, há que se recorrer ao exame de outros dispositivos constitucionais diretamente relacionados com o Orçamento.

Nessa linha, o art. 70 da Constituição da República revela, de forma expressa, a necessidade de se proceder à fiscalização orçamentária da União e das entidades da administração direta e indireta, quanto à legalidade, legitimidade e economicidade ${ }^{699}$.

Primeiramente, cabe considerar que, se o legislador constituinte entendeu necessária a existência de uma fiscalização do Orçamento, o fez exatamente porque a Lei de Orçamento há de ser respeitada. Caso a lei orçamentária revestisse uma natureza meramente formal, sem a existência de sanções ao seu descumprimento, não haveria qualquer sentido em se determinar a realização de uma fiscalização desse teor.

Mais do que isso, entendeu o legislador constituinte pátrio que a fiscalização do Orçamento se desse sob os auspícios não somente do princípio da legalidade, mas, ainda, da legitimidade e da economicidade, revelando a vontade de que tal fiscalização ocorresse amplamente, não adstrita a critérios meramente formais de legalidade.

No ordenamento brasileiro, a competência para o exercício do controle externo é enfeixada pelo Congresso Nacional, que conta com o auxílio do Tribunal de Contas da União $^{700}$.

Ao dever de prestar contas, encontra-se submetida qualquer pessoa física ou jurídica, pública ou privada, que utilize, arrecade, guarde, gerencie ou administre dinheiros, bens e valores públicos ou pelos quais a União responda ${ }^{701}$. Se assim é, todos

\footnotetext{
${ }^{699}$ Art. 70, caput, da CF/88.

${ }^{700}$ Art. 71 , caput, da CF/88.

${ }^{701}$ Art. 70, parágrafo único, CF/88.
} 
quantos lidem diretamente com o manejo dos recursos e da gestão orçamentária estão submetidos ao dever de prestação de contas, visto que exercem uma tarefa de administração e gerenciamento de bens que não lhe pertencem, embora lhe estejam confiados.

Há duas grandes categorias de contas públicas, para efeito de fiscalização e controle pelo Tribunal de Contas: i) contas anuais, apresentadas pelo Chefe do Executivo; e ii) contas prestadas pessoalmente por todos os responsáveis pela aplicação do dinheiro público $^{702}$. Tal distinção encontra lúcida explanação no Recurso Ordinário em Mandado de Segurança, transcrito abaixo:

\begin{abstract}
O conteúdo das contas globais prestadas pelo Chefe do Executivo é diverso do conteúdo das contas dos administradores e gestores de recurso público. As primeiras demonstram o retrato da situação das finanças da unidade federativa (União, Estados, DF e Municípios). Revelam o cumprir do orçamento, dos planos de governo, dos programas governamentais, demonstram os níveis de endividamento, o atender aos limites de gasto mínimo e máximo previstos no ordenamento para saúde, educação, gastos com pessoal. Consubstanciam-se, enfim, nos Balanços Gerais prescritos pela Lei 4.320/1964. Por isso, é que se submetem ao parecer prévio do Tribunal de Contas e ao julgamento pelo Parlamento (art. 71, I c./c. 49, IX da CF/88). As segundas - contas dos administradores e gestores públicos, dizem respeito ao dever de prestar (contas) de todos aqueles que lidam com recursos públicos, captam receitas, ordenam despesas (art. 70, parágrafo único da CF/88). Submetem-se a julgamento direto pelos Tribunais de Contas, podendo gerar imputação de débito e multa (art. 71 , II e $\S 3^{\circ}$, da CF/88) ${ }^{703}$.
\end{abstract}

Referida distinção, portanto, encontra amparo constitucional, como se nota da diferença entre a função que compete às Cortes de Contas em relação aos incisos I e II do art. 70 da Carta Magna, in verbis:

Art. 71. O controle externo, a cargo do Congresso Nacional, será exercido com o auxílio do Tribunal de Contas da União, ao qual compete:

I - apreciar as contas prestadas anualmente pelo Presidente da República, mediante parecer prévio que deverá ser elaborado em sessenta dias a contar de seu recebimento; II - julgar as contas dos administradores e demais responsáveis por dinheiros, bens e valores públicos da administração direta e indireta, incluídas as fundações e sociedades instituídas e mantidas pelo Poder Público federal, e as contas daqueles que derem causa a perda, extravio ou outra irregularidade de que resulte prejuízo ao erário público;

No inciso I está-se à frente do parecer prévio das contas prestadas pelo Chefe do Executivo incumbência atribuída às Cortes de Contas, e que é posteriormente complementada por meio do julgamento anual das contas do Chefe do Executivo,

\footnotetext{
${ }^{702}$ FARIA, Edimur Ferreira de, op. cit., p. 683.

${ }^{703}$ RO em MS 11.060/GO, rel. Min. Laurita Vaz, redator p/ acórdão Min. Paulo Medina, DJU 16.09.2002, seção 1, p. 159.
} 
competência exclusiva do Congresso Nacional ${ }^{704}$. Por sua vez, o inciso II trata de julgamento das contas apresentadas pelos administradores e gestores públicos, tarefa esta realizada diretamente pelos Tribunais de Contas.

Tanto no caso do parecer prévio quanto no caso do julgamento direto das contas dos administradores públicos, pelo Tribunal de Contas, têm-se a apreciação da regularidade da gestão orçamentária desempenhada, ou, em outras palavras, inclui-se a verificação do cumprimento da Lei de Orçamento. Portanto, depreende-se do texto constitucional que as infrações perpetradas à lei orçamentária poderão ensejar, inclusive, parecer contrário à aprovação das contas do Executivo pelo Tribunal de Contas ou o julgamento de irregularidade das contas apresentadas pelos administradores e demais responsáveis pelos bens públicos.

Isso, sem se destacar o julgamento político da regularidade das contas do Chefe do Executivo, pelo Congresso Nacional:

O controle efetuado pelo Poder Legislativo é, sobretudo, um controle político. A corroborar tal afirmativa temos que o parecer prévio sobre as contas anuais do Governo oferecido pelo Tribunal de Contas, embora indispensável, pode ser rechaçado, não vinculando a decisão (política) do Parlamento ${ }^{705}$.

Ademais, o texto constitucional também prevê que a ilegalidade de despesa ou a irregularidade de contas enseja a aplicação de sanções estabelecidas em lei, inclusive de aplicação de multa proporcional ao dano causado ao erário, in verbis:

Art. 71 .

(...)

VIII - aplicar aos responsáveis, em caso de ilegalidade de despesa ou irregularidade de contas, as sanções previstas em lei, que estabelecerá, entre outras cominações, multa proporcional ao dano causado ao erário;

Aqui se retoma a síntese já mencionada sobre as sanções à Lei de Orçamento: $o$ núcleo sancionatório da Lei Orçamentária é depreendido do texto constitucional, embora seja integrado por meio de edição de leis específicas que suprirão a impossibilidade de a própria lei orçamentária dar o tratamento às vedações de seus dispositivos. Nesse caso, a exemplo daquele relativo ao crime de responsabilidade, o próprio texto constitucional remete à regulamentação por meio de uma lei ordinária específica.

\footnotetext{
${ }^{704}$ Art. 49, IX, CF/88.

${ }^{705}$ FARIA, Rodrigo Oliveira de. Arts. 75 a 82. In: Orçamentos Públicos. A Lei no $4.320 / 64$ Comentada. CONTI, José Mauricio (Coord.). São Paulo: Editora Revista dos Tribunais, 2008, p. 242.
} 
Ora, no ordenamento brasileiro, a despesa somente pode ser realizada caso não exceda os créditos orçamentários ou adicionais ${ }^{706}$. Além disso, veda-se de forma expressa a abertura de crédito suplementar ou especial sem prévia autorização legislativa e sem indicação dos recursos correspondentes, além da transposição, remanejamento ou transferência de recursos de uma categoria de programação para outra ou de um órgão para outro, sem prévia autorização legislativa ${ }^{707}$.

Ademais, a realização da despesa se encontra submetida a outras regras de regência, a exemplo dos arts. 15 a17 da Lei de Responsabilidade Fiscal. São consideradas não autorizadas, irregulares e lesivas ao patrimônio público as despesas que não atendam uma série de condicionantes prévias em sua geração ${ }^{708}$, notadamente a estimativa do impacto orçamentário-financeiro e adequação com as três leis orçamentárias - LOA, LDO e PPA. A observância de tais normas constitui, ainda, condição prévia para empenho e licitação de serviços, fornecimento de bens ou execução de obras ${ }^{709}$.

A despesa obrigatória de caráter continuado, considerada como aquela que fixa para o ente a obrigação legal de sua execução por um período superior a dois exercícios ${ }^{710}$, somente pode ser criada ou aumentada caso não afete as metas de resultado primário, além da necessária compensação de seus efeitos financeiros por meio do aumento permanente da receita ou pela redução permanente da despesa ${ }^{711}$.

Portanto, se os Tribunais de Contas possuem a incumbência de fiscalizar eventual ilegalidade de despesa, haverá, em consequência, a possibilidade de aplicação das sanções previstas em lei, em todos os casos em que a realização da despesa se dê de forma contrária ao preceituado em nosso ordenamento, salientando-se, nesse tocante, a importância do cumprimento dos ditames previstos na própria Lei de Orçamento, seja em termos de fixação de despesa às unidades orçamentárias, seja em termos de autorização facultada para a modificação e remanejamento dos créditos orçamentários.

No mesmo sentido, encontram-se artigos da Lei 4.320/64, pois é vedada a realização de despesa sem prévio empenho ${ }^{712}$ e o empenho da despesa não pode exceder o limite dos créditos concedidos ${ }^{713}$. Além disso, o controle da execução orçamentária deve

\footnotetext{
${ }^{706}$ Art. 167, II, da CF/88.

${ }^{707}$ Art. 167, V e VI, da CF/88.

${ }^{708}$ Art. 15 da LRF.

${ }^{709}$ Art. $16, \S 4^{\text {o }}$, I, da LRF.

${ }^{710}$ Art. 17, caput, da LRF.

${ }^{711}$ Art. 17, § 2 ${ }^{\circ}$, da LRF.

712 Art. 60, caput, da Lei no 4.320/64.

713 Art. 59, caput, da Lei no 4.320/64.
} 
compreender a legalidade dos atos de que resultem a arrecadação da receita ou a realização da despesa; a fidelidade funcional dos agentes da administração e o cumprimento do programa de trabalho expresso em termos monetários e em termos de realização de obras e prestação de serviços $^{714}$.

Há que se registrar que se encontrarão submetidos às penalidades assinaladas na legislação os ordenadores de despesa, bem como os responsáveis por dinheiros, bens e valores públicos da Administração direta e indireta.

Em nosso ordenamento, define-se ordenador de despesas como toda e qualquer autoridade de cujos atos resultarem emissão de empenho, autorização de pagamento, suprimento ou dispêndio de recurso da União ou pela qual esta responda ${ }^{715}$. Contudo, há que se deixar consignadas as importantes observações feitas por Mileski a respeito do tema. Afinal,

para identificação do ordenador de despesa é importante que este só possa assim ser considerado quando investido de autoridade administrativa, via de conseqüência, não podendo ser reconhecido na pessoa do agente subordinado. Por isso, o simples assinador do empenho, o servidor que realiza a liquidação da despesa ou o seu pagamento, em princípio, não pode ser identificado como ordenador de despesa. Ordenador de despesa é a autoridade administrativa, o responsável mor, com poderes e competência para determinar ou não a realização da despesa, de cujo ato gerencial surge a obrigação de justificar o bom e regular uso dos dinheiros públicos ${ }^{716}$.

E o mesmo autor complementa:

Ostentam a condição de Ordenadores de Despesa originários os Presidentes dos Poderes Legislativo e Judiciário; os Ministros e Secretários de Estado, assim como os dirigentes de autarquias, fundações, sociedades de economia mista e empresas públicas, por possuírem competências e atribuições fixadas em lei, regulamentos ou estatutos societários, para administrarem estas organizações estatais, aplicando os recursos financeiros postos a sua disposição ${ }^{717}$.

A par da figura do ordenador de despesas, o art. 78 da Lei $n^{\circ} 4.320 / 64$ menciona os responsáveis por bens ou valores públicos. O texto constitucional também utiliza uma figura mais ampla do que apenas os ordenadores de despesa, uma vez que se encontram submetidos à jurisdição das Cortes de Contas todos os responsáveis por dinheiros, bens e valores públicos da Administração direta e indireta ${ }^{718}$. Nesse sentido, toda a autoridade que

\footnotetext{
${ }^{714}$ Art. 75, I, II e III, da Lei $\mathrm{n}^{\circ} 4.320 / 64$.

715 Art. 80, § $1^{\circ}$, do Decreto-lei no $200 / 67$.

${ }^{716}$ MILESKI, Helio Saul. O controle da gestão pública. São Paulo: RT, 2003, p. 121.

${ }^{717}$ Ibid., p. 122/123.

${ }^{718}$ Art. 71, II, da CF/88.
} 
utilize, arrecade, gerencie ou administre dinheiros, bens e valores públicos submete-se ao processo de tomada de $\operatorname{contas}^{719}$.

Feitas tais considerações, há que se proceder ao exame sucinto do tratamento das infrações à LOA, conforme disciplinadas na legislação própria.

A princípio, cabe verificar o tratamento dos crimes de responsabilidade, relativamente às infringências cometidas contra a Lei de Orçamento. Para José Afonso da Silva, esses crimes podem ser divididos em infrações políticas e crimes funcionais. As infrações à lei orçamentária configuram-se como espécie de crimes funcionais, em conformidade com tal entendimento ${ }^{720}$.

O processo dos crimes de responsabilidade apresenta-se dividido em duas partes: juízo de admissibilidade e processo e julgamento ${ }^{721}$. A acusação poderá ser formulada por qualquer brasileiro perante a Câmara dos Deputados, que conhecerá, ou não, da denúncia. Caso dois terços dos membros da Câmara declarem procedente a acusação ${ }^{722}$, será autorizada a instauração do processo. Autorizada a instauração do processo pela Câmara, não há que se falar em juízo de admissibilidade por parte do Senado Federal. Ao Senado Federal, caberá o julgamento do crime de responsabilidade, por se tratar de matéria de sua competência.

A condenação pelo Senado Federal requer o voto de dois terços dos seus membros, “limitando-se a decisão à perda do cargo, com inabilitação por oito anos, para o exercício da função pública, sem prejuízo das demais sanções judiciais cabíveis (art. 52, parágrafo único). É isso que caracteriza o chamado impeachment" ${ }^{723}$.

A Lei $\mathrm{n}^{\circ} 1.079 / 50$ define os crimes de responsabilidade e regula o respectivo processo de julgamento. Entre os crimes definidos no referido diploma legal, incluem-se vários diretamente relacionados com a violação da lei orçamentária, seja pela autoridade máxima da Administração Pública Federal, o Presidente da República, seja pelos Ministros de Estado ${ }^{724}$. A lei ainda submete aos seus dispositivos os Governadores dos Estados e respectivos Secretários ${ }^{725}$.

Nos termos dessa Lei,

\footnotetext{
${ }^{719}$ MILESKI, Helio Saul, op. cit., p. 125.

${ }^{720}$ SILVA, José Afonso da. Curso de Direito Constitucional Positivo. 26a ed. São Paulo: Malheiros, 2006, p. $550 / 551$.

721 Ibid., p. 551.

722 Art. 86, caput, da CF/88.

${ }^{723}$ SILVA, José Afonso da, op. cit., p. 551.

${ }^{724}$ Art. 13 da Lei $n^{\circ} 1.079 / 50$.

${ }^{725}$ Art. 74 da Lei ${ }^{\circ} 1.079 / 50$.
} 
Art. 10. São crimes de responsabilidade contra a lei orçamentária:

1- Não apresentar ao Congresso Nacional a proposta do orçamento da República dentro dos primeiros dois meses de cada sessão legislativa;

2 - Exceder ou transportar, sem autorização legal, as verbas do orçamento;

3 - Realizar o estorno de verbas;

4 - Infringir, patentemente, e de qualquer modo, dispositivo da lei orçamentária.

Os crimes definidos, ainda quando simplesmente tentados, ensejam a aplicação das penas de perda de cargo, com inabilitação, até 5 anos, para o exercício de qualquer função pública, imposta pelo Senado Federal nos processos contra o Presidente da República ou os Ministros de Estado ${ }^{726}$.

Cabe, por último, tecer ligeiras considerações acerca da Lei $\mathrm{n}^{\circ}$ 8.443/92, Lei Orgânica do Tribunal de Contas da União, que tratou de regulamentar, inclusive, as penalidades ou sanções a serem aplicadas no caso de ilegalidade de despesa ou irregularidade de contas, conforme previsão constitucional.

Nos termos dessa lei, as contas dos administradores e responsáveis serão anualmente submetidas a julgamento do TCU, sob forma de tomada ou prestação de contas, devendo ser incluídos todos os recursos, orçamentários e extraorçamentários, geridos pela entidade ${ }^{727}$.

As contas podem ser julgadas regulares, regulares com ressalva ou irregulares, na seguinte conformidade:

Art. 16. As contas serão julgadas:

I - regulares, quando expressarem, de forma clara e objetiva, a exatidão dos demonstrativos contábeis, a legalidade, a legitimidade e a economicidade dos atos de gestão do responsável;

II - regulares com ressalva, quando evidenciarem impropriedade ou qualquer outra falta de natureza formal de que não resulte dano ao Erário;

III - irregulares, quando comprovada qualquer das seguintes ocorrências:

a) omissão no dever de prestar contas;

b) prática de ato de gestão ilegal, ilegítimo, antieconômico, ou infração à norma legal ou regulamentar de natureza contábil, financeira, orçamentária, operacional ou patrimonial;

c) dano ao Erário decorrente de ato de gestão ilegítimo ao antieconômico;

d) desfalque ou desvio de dinheiros, bens ou valores públicos.

Quando o responsável for julgado em débito, poderá o Tribunal aplicar-lhe multa de até $100 \%$ do valor atualizado do dano causado ao erário ${ }^{728}$. O valor da multa passível de

${ }^{726}$ Art. $2^{\circ}$ da Lei ${ }^{\circ}$ 1.079/50.
${ }^{727}$ Art. $7^{\circ}$ da Lei ${ }^{\circ}$ 8.443/92.
${ }^{728}$ Art. 57 da Lei $n^{\circ} 8.443 / 92$. 
ser aplicada ao administrador público é atualizada, periodicamente, por portaria do Presidente do Tribunal ${ }^{729}$.

Por último, assentada a existência de sanções pelas infringências à Lei de Orçamento, cabe delinear os contornos de tais desvios, para salientar o caráter essencial da violação da lei orçamentária. E tal caráter, por excelência, não se aplica a uma mera divergência formal entre valores previstos e valores executados, ou, conforme destacava Laband, nos gastos adicionais, nas economias de gastos, nas reduções dos ingressos e nos excessos de arrecadação ${ }^{730}$.

O descumprimento da Lei de Orçamento não se revela por aspectos formais ou de meras divergências entre as previsões e a execução, desde que autorizadas pelo Legislativo, visto que tais aspectos não dão conta do alcance das finalidades pretendidas pela execução do Orçamento. Destarte, o cumprimento da Lei de Orçamento se revela pelo grau de alcance dos objetivos e metas fixados em seu corpo, em sua essência. Por sua vez, a medida do descumprimento da LOA somente poderá ser aferida pela verificação do grau de falhas em sua execução, pelo número de programas que não alcançaram as finalidades a que se propunham, pelo descumprimento das metas fiscais que orientavam a lei orçamentária e pelos resultados ineficientes e ineficazes alcançados.

Indiscutivelmente, os países mais desenvolvidos em termos orçamentários apresentam uma maior proximidade entre os valores previstos e os valores executados, e as divergências havidas entre o grau de execução de nosso orçamento e a sua previsão inicial revelam o caminho que ainda deve ser percorrido, no processo de amadurecimento de nossas instituições orçamentárias.

Todavia, a quantidade de modificações ou alterações do Orçamento, no Brasil, antes de indício de descumprimento da vontade do Legislativo, encontra-se relacionada a problemas de planejamento, em que órgãos e entidades falham na elaboração prévia de seus planos e dos recursos que serão necessários ao desenvolvimento de suas atividades.

De toda forma, pretende-se ressaltar que, juridicamente, o grau de cumprimento do Orçamento somente se revela pela verificação do alcance dos fins a que se destina a Lei de Orçamento; em consequência, seu descumprimento é verificado pelo grau de fracasso na perseguição dos objetivos e metas traçados inicialmente. E, para que tal verificação possa

\footnotetext{
${ }^{729}$ Art. 58, § $2^{\text {o }}$, da Lei ${ }^{\circ} 8.443 / 92$.

${ }^{730}$ LABAND, Paul. Derecho Presupuestario. Trad. Jose Zamit. Madrid: Instituto de Estudios Fiscales, 1979, p. 90.
} 
ser feita de forma razoável, não existe outro meio a não ser o da a averiguação específica da multiplicidade oferecida pelo exame dos casos concretos.

Em resumo, há que se destacar a multiplicidade de sanções decorrentes do descumprimento da Lei de Orçamento, que vai de um espectro que abrange desde a irregularidade de despesa e aplicação de multa, passando pelo julgamento das contas dos responsáveis pela gestão orçamentária, pelo parecer prévio das Cortes de Contas, até eventual caracterização de crime de responsabilidade e julgamento político das contas do Chefe do Executivo, pelo Legislativo. Essas sanções aplicam-se desde o ordenador da despesa e o administrador responsável, dirigentes de órgãos e entidades, Ministros e Secretários de Estado, culminando naquele que ocupa o ápice das tarefas de direção do Estado, o Presidente da República.

Destarte, em nosso ordenamento, não se pode advogar a inexistência de sanções ao descumprimento da LOA, fato que o entendimento de sua força e vigor, a orientarem a execução das atividades administrativas necessárias ao desenvolvimento das políticas públicas e dos programas orçamentários. Portanto, a coercibilidade ${ }^{731}$ de que se encontra enfeixada a Lei de Orçamento, em nosso ordenamento, destoa do entendimento clássico de inexistência de consequências jurídicas às violações perpetradas contra a lei orçamentária.

\subsection{Validade do Duplo Conceito de Lei e enquadramento da Lei de Orçamento}

\subsubsection{Validade atual da Teoria do Duplo Conceito de Lei}

A teoria clássica de Orçamento procura assentar na distinção entre lei formal e lei material, e na caracterização da Lei de Orçamento como uma lei formal - ato administrativo revestido das formalidades de aprovação pelo Legislativo - os motivos ensejadores da impossibilidade de alteração da ampla maioria das despesas pelo Legislativo e, em consequência, da desnecessidade de aprovação da lei orçamentária pelo Parlamento para a execução dos gastos e condução da máquina governamental pelo Poder Executivo.

\footnotetext{
${ }^{731}$ Como destaca Miguel Reale, "a coercibilidade não assinala simples conformidade lógica entre Direito e coação, mas também uma exigência axiológica: a coação liga-se ao dever ser do Direito, pois, quando a norma jurídica primária, que contém o preceito de conduta, não é espontaneamente cumprida, impõe-se o advento de dadas consequências, as quais podem consistir no cumprimento forçado da regra infringida, ou em uma pena correspondente ao valor do Direito cuja reintegração se haja tornado impossível". REALE, Miguel. Filosofia do Direito. 20a ed. São Paulo: Saraiva, 2009, p. 708.
} 
Para Laband, não seria lei toda manifestação da vontade estatal, mas somente aquela cujo conteúdo consubstanciasse um preceito jurídico, uma norma para regular ou resolver relações jurídicas ${ }^{732}$. Nesse sentido, a lei poderia se equivaler, sob uma perspectiva material, a uma medida administrativa:

La Ley Constitucional llama al establecimiento de preceptos jurídicos sin la aprobación de las Cámaras, 'reglamentos' (...) De esta distinción se deriva, para el concepto de ley en sentido estricto, una característica formal: la conformidad de la Corona y del Parlamento ${ }^{733}$.

Na perspectiva labandiana a implantação do regime constitucional teria restringido o conceito de lei ${ }^{734}$ ao acrescentar a necessidade de observância de um requisito externo $e$ formal, ensejando a possibilidade de existência de leis aprovadas pelo Legislativo que não consubstanciariam verdadeiras regras jurídicas. Em suas palavras:

el establecimiento de la forma constitucional no se ha ensanchado el concepto de las leyes, sino que se ha restringido. Al requisito material del concepto, de que la ley ha de contener una regla jurídica, se ha añadido otro requisito externo y formal. (...) se llaman leyes en sentido estricto o constitucional (...) una manifestación de la voluntad del Estado que no encaje en el concepto del precepto jurídico, es decir: en el concepto de ley en el sentido amplio del término, no puede adquirir este carácter ni siquiera por el hecho de que dicha voluntad estatal se manifieste con la conformidad de la Corona y de la representación popular ${ }^{735}$.

Em síntese, o conceito de lei material aponta somente para os atos que contenham um preceito jurídico, e, dentro dessa concepção, não se exige que as regras jurídicas formuladas sejam gerais ou permanentes ${ }^{736}$.

O Orçamento, por não conter princípios jurídicos, não seria uma lei no sentido material da palavra. Na verdade, seria apenas uma conta por meio da qual se registrariam os gastos e ingressos previstos. Além disso, não fundamentaria a obrigação jurídica de recebimento das receitas ou de realização das despesas ${ }^{737}$.

A elaboração do Orçamento figuraria, com maior acerto, no âmbito das atribuições da Administração, não tendo qualquer relação com as atividades legislativas ${ }^{738}$. Para

\footnotetext{
${ }^{732}$ LABAND, Paul, op. cit., p. 08.

${ }^{733}$ Ibid., p. 10.

${ }^{734}$ Ibid., p. 09.

${ }^{735}$ Ibid., p. 11.

${ }^{736}$ Ibid., p. 08.

${ }^{737}$ Ibid., p. 23.

${ }^{738}$ Ibid., p. 23.
} 
reforçar tal entendimento, Laband divide a Lei de Orçamento em duas partes muito distintas: o Orçamento propriamente dito e a lei que o aprova ${ }^{739}$.

Pelo fato de existir essa dualidade intrínseca à lei orçamentária, o doutrinador concebe a possibilidade de que dispositivos de caráter material sejam incluídos na Lei de Orçamento, sem deixar de consignar sua crítica a tal procedimento:

Puede ser inoportuno cargarle a la ley que establece el Presupuesto un contenido que puede formularse igualmente en una ley especial; pero si el Gobierno y las dos Cámaras están de acuerdo en vincular al acto de fijación del Presupuesto tales disposiciones legales y si la Corona sanciona una ley así formulada y la promulga de acuerdo con los trámites constitucionales, la validez jurídico-pública de dicha ley no puede ser impugnada, ni en su totalidad, ni en alguna de sus partes, por el hecho de que la ley sólo está tipificada como tal ley para establecer y fijar el Presupuesto de un determinado año $^{740}$.

É ainda Laband que admite a possibilidade de o Orçamento possuir autêntica força de lei, desde que contivesse, simultaneamente, uma ordem e uma proibição, nos termos seguintes:

\footnotetext{
para que el Presupuesto tuviera auténtica fuerza de ley sería preciso que en él figuraran una orden positiva y, al mismo tiempo, una prohibición, dirigidas ambas al Gobierno y concebidas en los siguientes términos:

la orden de hacer efectivos los ingresos incluidos en el Presupuesto en la cuantía por éste indicada y de llevar a cabo los gastos enumerados en el Presupuesto, también en la cuantía por él indicada.

y la prohibición de hacer efectivo un ingreso y llevar a cabo un gasto que no se hallen establecidos en el Presupuesto ${ }^{741}$.
}

O desenvolvimento da teoria labandiana marcou, de forma indelével, a discussão sobre o caráter da Lei de Orçamento, tendo sido transplantada para outros ordenamentos jurídicos - mesmo diferentes - com pequenas adaptações. Como destaca Bereijo:

Lo curioso es que las teorías alemanas sobre el Derecho presupuestario formuladas al calor de la polémica del conflicto constitucional prusiano (...) habrían de tener una enorme repercusión en los demás países europeos - singularmente Italia y Francia -, algunos de cuyos tratadistas se convirtieron en ardientes defensores de la doctrina alemana sobre el Presupuesto: intentando trasladarla o adaptarla sin más, un tanto mecánicamente, a sus respectivos ordenamientos jurídicos ${ }^{742}$.

Adicionalmente, Canotilho também sinaliza nesse sentido:

\footnotetext{
${ }^{739}$ LABAND, Paul, op. cit., p. 28.

${ }^{740}$ Ibid., p. 29.

${ }^{741}$ Ibid., p. 89/90.

${ }^{742}$ BEREIJO, Alvaro Rodríguez. Laband y el Derecho Presupuestario del Imperio Aleman. In: LABAND, Paul. Derecho Presupuestario. Madrid: Instituto de Estudios Fiscales, 1979, p. XXXVII/XXXVIII.
} 
A lei do orçamento está indissociavelmente ligada à teoria do duplo conceito de lei. A distinção conceitual entre lei em sentido material e lei em sentido formal foi desenvolvida por Laband, tendo-se transformado num dogma científico para a doutrina alemã de direito público e, por via dela, das doutrinas francesa e italiana do direito financeiro e do direito constitucional ${ }^{743}$.

O desenvolvimento teórico e doutrinário posterior, contudo, tem indicado a insuficiência do duplo conceito de lei, face às grandes transformações por que passou o Estado contemporâneo. Inicialmente, cabe registrar que, na própria Alemanha, houve opiniões divergentes em relação à doutrina labandiana:

Na própria Alemanha, porém, a conceituação do orçamento como simples plano de gestão, de valor puramente programático, destituído de significação e de efeitos jurídicos, ou possuindo apenas significação política, limitada às relações domésticas dos órgãos supremos do Estado entre si, não reuniu o sufrágio unânime das mais altas autoridades em matéria de Direito Constitucional alemão ${ }^{744}$.

Um dos doutrinadores que apresentou críticas ao duplo conceito de lei, Phillippe Zorn, citado por Francisco Campos, destacava a existência de proposição jurídica em todas as leis, de forma taxativa:

a distinção (lei formal e lei material) estabelecida por Laband parece insustentável. Não existem leis em sentido formal, ou no sentido que Laband atribui a essa expressão. Seja qual for o conteúdo da lei: toda lei contém uma regra jurídica. Lei é a decisão do Estado de que alguma coisa deve ser Direito. Lei, em sentido estrito, é a ordem dada aos súditos pelo titular da Soberania, com o assentimento da representação popular de observar um determinado preceito. (...) Só existe uma força de lei, e não existe nenhuma lei sem força de lei. A lei, seja qual for o seu conteúdo, é, em quaisquer circunstâncias, direito objetivo, regra jurídica; lei que não contenha proposição jurídica, que apenas formalmente ou na aparência se apresenta como lei, não existe ${ }^{745}$.

Noutra perspectiva, Francisco Campos realçou o desprezo das normas constitucionais por parte desta linha doutrinária, que se encontra em dissonância com as modernas concepções que emprestam relevante significado à força normativa da Constituição. Nas palavras de Francisco Campos:

A Constituição, para Laband, assim como para os teóricos do Direito Constitucional alemão, era uma realidade de natureza exclusivamente política. As transgressões da

${ }^{743}$ CANOTILHO, José Joaquim Gomes. A Lei do Orçamento. In Estudos em Homenagem ao Prof. Doutor J. J. Teixeira Ribeiro. Universidade de Coimbra: Boletim da Faculdade de Direito, Número Especial, 1979, p. 546.

${ }^{744}$ CAMPOS, Francisco. Orçamento - Natureza Jurídica. RDA no 71. Jan/mar 1963, p. 328.

745 ZORN, Phillippe. Das Staatsrecht des Deutschen Reichs. $2^{\mathrm{a}}$ ed. Vol. I, p. 442/444. Apud CAMPOS, Francisco. Orçamento - Natureza Jurídica. RDA no 71. Jan/mar 1963, p. 328. 
Constituição não podiam ter, portanto, qualquer sentido ou conseqüência de caráter jurídico. Daí se origina a tentativa de Laband e dos sequazes da sua doutrina do orçamento de rebaixar a lei orçamentária a um simples quadro, de valor puramente aritmético ou contabilístico, da receita e da despesa nacionais. Não os impressionou o fato de haverem sido elevados à categoria de normas de constituição as regras fundamentais da elaboração orçamentária. Apesar do mandamento constitucional de que o orçamento devia revestir a forma de lei e nele deverem ser computadas todas as receitas e despesas da Nação, Laband não se deixou impressionar pela clara intenção manifestada pela alta categoria de regra assim formulada, de que o orçamento não seria uma simples operação material ou de contas de 'deve e haver', mas, igualmente, um ato de vontade do parlamento no sentido de limitar os poderes financeiros do Governo às possibilidades, quanto à receita e à despesa, manifestadas nas respectivas tabelas orçamentárias $^{746}$.

Canotilho também realça os critérios constitucionais, enquanto balizas

fundamentais para a caracterização da lei e de seu significado:

Desde a Constituição francesa de 1791 que o conceito de lei se identifica com um conceito constitucional de lei que, por sua vez, se reconduz a normas nas quais o povo participa. (...) Desta forma, não se poderia falar de leis meramente formais, porque toda a deliberação emanada sob a forma legislativa do Parlamento constitui uma norma superior de direito. Numa palavra: os actos legislativos das assembleias representativas têm força e valor de lei. Daí que hoje a doutrina tenda a considerar superado o duplo conceito de lei e opte por uma delimitação do acto legislativo, ancorada em dados sobretudo formais, como intuira Haenel que, ao opor-se ao conceito labandiano de lei, considerava já que todo o acto revestido da forma de lei leva em si mesmo um conteúdo jurídico $^{747}$.

Para além dessas questões, há que se mencionar o alargamento do conteúdo da lei.

A incorporação de conteúdo diverso daquele que lhe fora tradicionalmente emprestado é sintoma notório da insuficiência da concepção clássica da lei. Nessa concepção, Cabral de Moncada evidencia a progressiva desconformidade do conceito de lei em relação aos parâmetros clássicos:

Findo o período Weimariano, começou a doutrina a pôr em evidência as incapacidades da dogmática clássica para traduzir a riqueza de manifestações da moderna actividade administrativa, sobretudo daquela que se traduz na atribuição de prestações económicas e sociais aos cidadãos em geral através de uma vasta rede de serviços públicos, desenvolvendo uma função de curadoria da existência individual e social com tanta importância para a situação do cidadão como as formas tradicionais da actividade administrativa. (...) O conceito tradicional de Rechtsatz não se mostrava apropriado para fazer abarcar pelo âmbito da norma jurídica de origem parlamentar tão vastas e complexas actividades cujo conteúdo nada tinha que ver com aquele que tradicionalmente se imputava à lei. Desde cedo que a doutrina foi colocada perante a seguinte encruzilhada; ou alargar o conceito de lei, nela incluindo as nóveis direcções e modalidades da actividade dos poderes públicos ou remetê-las pura e simplesmente para a esfera do Executivo constituindo-o a breve trecho no mais poderoso poder estadual. A estrutura constitucional alemã não comporta a segunda solução. Daí que a orientação

\footnotetext{
${ }^{746}$ CAMPOS, Francisco, op. cit., p. 331.

${ }^{747}$ CANOTILHO, José Joaquim Gomes, op. cit., p. 553.
} 
dominante tenha sido no sentido da primeira; alargar o conceito de lei (parlamentar) de modo a fazê-la abarcar o essencial das novas modalidades da acção administrativa, fazendo jus ao modelo político de predominância parlamentar que a nova constituição alemã consagra $^{748}$.

No mesmo diapasão, Bereijo realça as progressivas transformações que se incorporam ao conceito de lei:

\begin{abstract}
Pero el estrecho concepto labandiano de norma jurídica (= ley material), que suponía una concepción puramente individualista de la libertad y de la propiedad, habría de resultar, de un modo patente, inadecuado e inservible a medida que las transformaciones de la sociedad y del Estado modernos (hasta llegar al actual Estado social y democrático de Derecho) pusieron en evidencia que no basta sólo con la protección de la libertad ciudadana en el sentido del status negativus (Jellinek), que no basta con esperar del Estado solamente esa garantía negativa de la libertad, sino que se hace cada vez más imperiosa la necesidad de creación de una garantía positiva, de instituciones que aseguren ampliamente la libertad y la propiedad mediante la organización estatal, la dirección estatal del Presupuesto, las prestaciones estatales de bienes y servicios etc... Por ello, como dice Christian Starck, 'se hace preciso extender el concepto de norma jurídica para que pueda abarcar no sólo la concepción jurídico-individualista (delimitación y coordinación de esferas de voluntad), que por lo demás hay que mantener, sino todas las normas sobre organización y procedimiento del Derecho estatal y público en general, todas aquellos preceptos jurídicos que sientan el fundamento del uso del poder estatal y de cualquier otro poder público, y que regulan al detalle su estructura, su configuración y todas sus actividades', pues tambien el Derecho Público de Organización tiene como función asegurar la libertad.

Por otro lado, es preciso no olvidar que el Estado social y democrático de Derecho de nuestros días, que se basa en una Administración prestadora de bienes y servicios públicos, tiene como valores superiores de su ordenamiento jurídico no sólo da idea de libertad, sino también las de igualdad y justicia ${ }^{749}$.
\end{abstract}

Além disso, a racionalidade operativa da limitação da função orçamentária do Poder Legislativo ${ }^{750}$, típica da concepção clássica, também entra em rota de colisão com uma reivindicação mais ampla do domínio parlamentar, por meio da qual se enfatiza o papel dirigente do Legislativo, em contraposição àquela que resultava da noção clássica de lei. Nas palavras de Moncada:

se poderá reivindicar para o tratamento parlamentar todo o conjunto de temas que se afigurarem como os essenciais em dado momento histórico e mesmo os que a ordem constitucional positiva não tenha incluído no catálogo das competências parlamentares. Sem dúvida que o resultado a que se chega não é rígido e apresenta alguma margem de incerteza, mas é esse o preço a pagar por uma concepção de lei que se mostre adequada não só ao papel dirigente do Parlamento como também a proteger definitivamente o cidadão frente às arremetidas do Executivo e mesmo que este tenha deixado de ser visto

\footnotetext{
${ }^{748}$ MONCADA, Luís S. Cabral de. A Reserva de Lei no Actual Direito Público Alemão. In: Estudos de Direito Público. Coimbra Editora, 2001, p. 105.

${ }^{749}$ BEREIJO, Álvaro Rodriguez. Orçamento III. Revista de Direito Público no 96. Out/dez 1990. Ano 24. p. 24.

750 Idem. Laband y el Derecho Presupuestario del Imperio Aleman. In: LABAND, Paul. Derecho Presupuestario. Madrid: Instituto de Estudios Fiscales, 1979, p. LXI.
} 
como o seu inimigo principal. Fundamental é a noção de que o conceito material de lei está na ordem do dia, não pertencendo só à dogmática do passado; um conceito de lei suficientemente firme para garantir ao Parlamento um papel preponderante como órgão normativo e maleável quanto baste para não reduzir ao nada a posição de um Executivo que se apresenta agora vocacionado para novas e singulares tarefas e beneficiando de uma nova legitimidade ${ }^{751}$.

\section{A ampliação da atuação parlamentar para abarcar atos de direção política} consubstanciados em lei também é enfatizada por Canotilho em linhas argumentativas semelhantes:

Ao contrário do que estava subjacente nas doutrinas do duplo conceito de lei e de reserva de lei, a intervenção parlamentar não se limita a uma actuação legislativa, cabendo ao Governo as tarefas de direcção política; pelo contrário, as estruturas constitucionais parlamentares apontam para a necessária participação das assembleias representativas em actos de direcção política. A fixação do plano orçamental seria um acto desta natureza, justificando uma reserva de Parlamento. (...)

A reserva absoluta de lei formal é, antes de reserva de lei, uma verdadeira reserva de Parlamento. A intervenção do órgão representativo num acto de direcção política essencial como é o plano financeiro deve ser estritamente garantida não já no sentido de que falava C. Schmitt, como um meio de luta da burguesia contra um executivo não legitimado democraticamente, mas no sentido de intensificação da legitimidade democrática $^{752}$.

No mesmo aspecto são as lições de Bereijo:

se asegura el control democrático por la representación popular no sólo de la actividad financiera del Estado, sino también de las directrices y de la orientación de la política del Gobierno; (...) la colaboración del legislativo en el procedimiento presupuestario tiene el efecto de comprometer, politicamente, al Parlamento en la orientación política de al acción del Gobierno ${ }^{753}$.

Resumidamente, a aprovação da Lei de Orçamento, por meio da qual se materializa a adesão parlamentar a um ato de direção política fundamental, evidencia que o papel que se deseja do Parlamento não cabe dentro dos estritos limites da teoria clássica da lei:

A aprovação parlamentar da lei do orçamento representa sempre a adesão a um acto de direcção política fundamental, em que o Parlamento se vê associado à tarefa de corporizar, aprovando o orçamento, um 'impulso' político autônomo, assumindo ou não as opções políticas do Governo, ao mais alto nível de decisão dos órgãos do Estado e revestindo enquanto tal o conteúdo verdadeiramente substancial de uma lei ${ }^{754}$.

${ }^{751}$ MONCADA, Luís S. Cabral de. A Reserva de Lei no Actual Direito Público Alemão. In: Estudos de Direito Público. Coimbra Editora, 2001, p. 110/111.

${ }^{752}$ CANOTILHO, José Joaquim Gomes, op. cit., p. 575/576.

${ }_{753}$ BEREIJO, Álvaro Rodriguez. Orçamento I. Revista de Direito Público, ano 23, n. 94, p. 21, abr/jun. 1990.

${ }^{754}$ MONCADA, Luís S. Cabral de. Perspectivas do Novo Direito Orçamental Português. In: Estudos de Direito Público. [S.1]: Coimbra Editora, 2001, p. 92/93. 
Em outra vertente de questionamento da distinção clássica, Manoel Gonçalves Ferreira Filho aponta para o fato de que a lei, no regime constitucional pluralista contemporâneo, possui um caráter meramente formal, não havendo qualquer cogitação sobre o conteúdo da $l e i^{755}$. Tal constatação também termina por evidenciar a fragilidade da distinção baseada na dicotomia entre lei formal e lei material, nos dias atuais.

Nesse prisma, não haveria consequências práticas em se estabelecer essa distinção, visto que, quanto à eficácia, ambas estariam no mesmo plano. Para esse estudioso, "Essa distinção, contudo não traz vantagens, além de não ser, muita vez, fácil de marcar. De fato, quanto ao momento de instauração e, sobretudo, quanto à eficácia (que é o mais importante), a lei dita material e a lei dita formal estão num só e mesmo plano"756.

Atento a tal crítica e considerando o processo de transformação da lei clássica para a lei do Estado contemporâneo, Manoel Gonçalves propõe a classificação das leis em duas espécies: as leis de arbitragem e as leis instrumentais - ou leis de impulsão. As leis de arbitragem visariam a um equilíbrio entre a variedade de interesses dos diversos grupos componentes da sociedade, enquanto que as leis instrumentais se caracterizariam como meios para a realização de objetivos determinados, em consonância à aprovação $\operatorname{popular}^{757}$.

Para Moncada, a eficácia e a racionalidade que lhe é subjacente, ao se incorporarem à agenda e temática dos Estados modernos, também terminam por imprimir contornos diferenciados à lei, contribuindo para uma reformulação dos parâmetros até então utilizados:

É de um modo geral pacífico que as considerações de eficácia levam à alteração do tradicional conteúdo normativo geral e abstracto da lei. (...) É, portanto, normal que a lei possa revestir-se de um conteúdo individual e concreto, para além de se apresentar motivada por considerações de produtividade e rendimento, visto até como o mais apropriado para o tratamento proveitoso de certas questões, nomeadamente no âmbito da intervenção económica e social do Estado ${ }^{758}$.

E, em lúcida exposição, arremata:

O que se pretende da lei é que corporize uma forma de legitimação democrática, que se afigure como um texto (hoc sensu) compromissório, não que se meça por critérios científicos ou económicos. Pretender que a lei seja um modelo de clareza e razão é

\footnotetext{
${ }^{755}$ FERREIRA FILHO, Manoel Gonçalves. Do Processo Legislativo. 6a ed. São Paulo: Saraiva, 2007, p. 128.

756 Ibid., p. 204.

757 Ibid., p. 278.

${ }^{758}$ MONCADA, Luís S. Cabral de. Direito público e eficácia. In: Estudos de Direito Público. [S.1]: Coimbra Editora, 2001, p. 200/201.
} 
irrealista, até porque a racionalidade que a óptica da eficácia pretende da lei é completamente diferente da que lhe imputava a teoria clássica, baseada esta na generalidade e abstracção dos respectivos comandos. No entanto, a lei não pode deixar, no enquadramento do actual estado intervencionista, de se pautar por uma estratégia ${ }^{759}$.

Em conformidade com tal entendimento, pode-se afirmar que as leis "passaram a aferir-se também por critérios de conformidade aos fins (estratégicos) tidos em vista"760. Esse delineamento enquadra-se, com perfeição, aos contornos de que se reveste a Lei de Orçamento em nossos dias, que se pauta por considerações de eficácia e de estratégia.

Em síntese, seja pelo aspecto do progressivo alargamento do conceito de lei no processo de transformação do Estado contemporâneo, pelo realce da convergência da lei a um critério formal, ou, ainda, pela incorporação de uma racionalidade de eficácia, termina-se por se constatar a fragilidade da clássica abordagem dicotômica em nossos dias.

Também aponta nesse sentido, entre nós, a paulatina modificação do entendimento da mais alta Corte de Justiça brasileira quanto ao cabimento e à fiscalização da constitucionalidade da LOA.

Efetivamente, como destaca Canotilho, "as objecções à fiscalização da constitucionalidade da lei do orçamento radicam (...) na sobrevivência encapuçada ou não, dos dogmas conceitualistas da teoria do duplo conceito de lei" ${ }^{\text {761 }}$. Ou, nas palavras do jurista:

Um primeiro argumento contra a admissibilidade de fiscalização constitucional da lei do orçamento é este: a lei do orçamento é uma lei simplesmente formal e como o controlo da constitucionalidade é um controlo sobre normas, ficaria arredado, in limine, que leis não normativas pudessem ser objecto de um controlo de constitucionalidade. A restrição da fiscalização constitucional às leis materiais, pressupõe, como facilmente se intui, a relíquia doutrinal da teoria da norma jurídica e da doutrina do duplo conceito de lei ${ }^{762}$.

Em contraposição à argumentação utilizada para se afastar o exame de constitucionalidade das leis orçamentárias, Canotilho relembra que:

Os textos constitucionais positivos não estabelecem qualquer graduação dos actos legislativos que assegure uma base minimamente objectiva para a distinção entre leis normativas, sujeitas a controlo de inconstitucionalidade, e leis formais, isentas desse controlo $^{763}$.

${ }^{759}$ MONCADA, Luís S. Cabral de, op. cit., p. 210.

${ }^{760}$ Ibid., p. 211.

${ }^{761}$ CANOTILHO, José Joaquim Gomes. A Lei do Orçamento. In: Estudos em Homenagem ao Prof. Doutor J. J. Teixeira Ribeiro. Universidade de Coimbra: Boletim da Faculdade de Direito, Número Especial, 1979, p. 577.

762 Ibid., p. 578.

${ }^{763}$ Ibid., p. 578. 
Entre nós, a jurisprudência tradicional do Supremo Tribunal Federal considerava inadmissível a propositura de ação direta de inconstitucionalidade contra atos de efeito concreto, na esteira do seguinte entendimento:

A ação direta de inconstitucionalidade é o meio pelo qual se procede, por intermédio do Poder Judiciário, ao controle da constitucionalidade das normas jurídicas in abstrato. Não se presta ela, portanto, ao controle da constitucionalidade de atos administrativos que têm objeto determinado e destinatários certos, ainda que esses atos sejam editados sob a forma de lei - as leis meramente formais, porque têm forma de lei, mas seu conteúdo não encerra normas que disciplinem relações jurídicas em abstrato ${ }^{764}$.

Todavia, recentes decisões do Supremo apontam para uma alteração desse entendimento, a exemplo do reconhecimento do caráter normativo de disposições da LOA na Adin 2.925-8- $\mathrm{DF}^{765}$. A ementa transcrita ilustra tais conclusões:

PROCESSO OBJETIVO - AÇÃO DIRETA DE INCONSTITUCIONALIDADE - LEI ORÇAMENTÁRIA. Mostra-se adequado o controle concentrado de constitucionalidade quando a lei orçamentária revela contornos abstratos e autônomos, em abandono ao campo da eficácia concreta.

Em outra manifestação recente, o Ministro Gilmar Mendes deixou consignado que, tratando-se de atos editados sob a forma de lei:

houve por bem o constituinte não distinguir entre leis dotadas de generalidade e aqueloutras, conformadas sem o atributo da generalidade e abstração. Essas leis formais decorrem ou da vontade do legislador ou do desiderato do próprio constituinte, que exige que determinados atos, ainda que de efeito concreto, sejam editados sob a forma de lei (v.g. lei de orçamento, lei que institui empresa pública, sociedade de economia mista, autarquia e fundação pública) ${ }^{766}$.

$\mathrm{Na}$ esteira desse entendimento, deixa-se assentada a possibilidade de fiscalização da constitucionalidade das leis orçamentárias:

O Supremo Tribunal Federal deve exercer sua função precípua de fiscalização da constitucionalidade das leis e dos atos normativos quando houver um tema ou uma controvérsia constitucional suscitada em abstrato, independente do caráter geral ou específico, concreto ou abstrato de seu objeto. Possibilidade de submissão das normas de diretrizes orçamentárias ao controle abstrato de constitucionalidade ${ }^{767}$.

\footnotetext{
${ }^{764}$ ADIN 647-9-DF, Rel. Min. Moreira Alves, DJ 27.03.92, p. 252.

${ }^{765}$ ADIN 2.925-8-DF, Rel. Min. Ellen Gracie, DJ 04.03.2005, p. 112.

${ }^{766}$ Med.Cautelar em Adin no 3.949-1-MC/DF. Relator Min. Gilmar Mendes. DJ no 148. Publicação 07.08.09, p. $259 / 260$.

${ }_{767}$ Med.Cautelar em Adin no 3.949-1-MC/DF. Relator Min. Gilmar Mendes. DJe nº 148. Publicação 07.08.09.
} 
Destarte, a sobrevivência dos dogmas conceitualistas da teoria do duplo conceito de lei, como destacado por Canotilho, parece, cada vez mais, perder força. A possibilidade de fiscalização da constitucionalidade da Lei de Orçamento e o reconhecimento do caráter normativo de disposições contidas em seu corpo terminam por atestar tal fato.

Procurou-se, nessa primeira parte da seção demonstrar a insuficiência da clássica dicotomia entre lei formal e lei material em nossos dias. Contudo, ainda que se pudesse defender a razoabilidade de tal distinção, não é pacífico que a LOA possa ser classificada como mera lei formal, havendo manifestações doutrinárias em sentido contrário. Assim, passa-se a examinar as manifestações acerca da natureza jurídica da Lei de Orçamento, em consonância com a clássica distinção, procurando-se salientar as infindáveis divergências doutrinárias a respeito.

\subsubsection{Enquadramento jurídico da Lei de Orçamento no Brasil}

Anteriormente à Constituição de 1988, foram vários os autores que defenderam, entre nós, a natureza jurídica de lei formal dos orçamentos. Nessa ótica, Alberto Deodato, afirmava, em síntese, que a lei orçamentária "é a aprovação de uma conta e de um plano econômico"768. Por sua vez, Carvalho de Mendonça se posicionava entre os que não o definem como lei, vez que "os atos orçamentários não tem as condições de generalidade, constância ou permanência que dão cunho à verdadeira lei; não encerram declaração de direito; e não são mais do que medidas administrativas tomadas com a intervenção do aparelho legislativo" ${ }^{, 769}$.

Aliomar Baleeiro também figurou entre os defensores da lei formal: "o orçamento, como lei puramente formal, sem conteúdo material ou substancial de lei, não pode criar nem majorar impostos em suas disposições"

Isso não impediu, todavia, que existissem vozes em contrário. Francisco Campos, enfrentando a questão da natureza jurídica da lei orçamentária em parecer de 1963, fez contundente crítica à obra de Laband, defendendo que:

\footnotetext{
${ }^{768}$ DEODATO, Alberto. Manual de Ciência das Finanças. 20ª ed. São Paulo: Saraiva, 1984, p.272.

${ }^{769}$ MENDONÇA, Carvalho de, apud DEODATO, Alberto. Manual de Ciência das Finanças. $20^{\mathrm{a}}$ ed. São Paulo: Saraiva, 1984, p.272.

${ }^{770}$ BALEEIRO, Aliomar, op. cit., p. 443.
} 
O orçamento, ao contrário da assertiva dogmática de Laband, contém, portanto, um preceito jurídico de ordem geral, endereçado não somente à administração, como à generalidade dos indivíduos ou à coletividade humana, de cujos recursos o Estado absorve uma cota destinada às despesas de interesse comum. $\mathrm{O}$ preceito jurídico em questão é não somente uma regra jurídica, como contém, por igual, ordem, autorização e proibição, todos os elementos, em suma, cuja presença caracteriza, segundo Laband, a lei propriamente dita, ou a lei em sentido material $^{771}$.

Em linha semelhante, José Afonso da Silva dialoga com alguns dos pontos levantados pela teoria clássica de Orçamento, refutando a possibilidade de consideração da lei orçamentária como mero ato administrativo, ou como mera autorização, em termos gerais:

Em verdade, o orçamento somente adquire valor jurídico depois de sua aprovação pelo Poder Legislativo. Constitui inegavelmente um sistema de limites de atuação do Poder Executivo. Ora, se fosse materialmente ato administrativo, certamente que o Executivo poderia modificá-lo, sem autorização legislativa, desde que mantivesse o montante dos dispêndios originariamente fixado. É certo que os funcionários administrativos devem cumprir as metas previstas na programação orçamentária, e não o podem fazer livremente, mas nos termos e limites fixados na lei de orçamento. Não podem deixar de cumprir as atividades e projetos constantes da lei de orçamento, sem razão justificativa para tanto, ou com a simples justificativa de que não eram obrigados a executá-los, porquanto a lei não lhes dá mais do que uma autorização para isso, ficando sua efetivação dependendo de sua vontade exclusivamente.

Por isso mesmo se exige que o Executivo preste contas da execução da lei orçamentária ao Legislativo. Se se tratasse de ato administrativo ou ato-condição, essa exigência seria descabida $^{772}$.

E, desenvolvendo suas reflexões acerca da Lei de Orçamento, o jurista se inclina para a conclusão de que aquela seria uma lei material: "Concluindo, o orçamento-programa anual e o orçamento plurianual de investimento são leis, leis de impulsão na classificação já indicada do Prof. Manoel Gonçalves Ferreira Filho, e, portanto, lei em sentido material, segundo a classificação tradicional" ${ }^{\prime 773}$.

Posteriormente à promulgação da Constituição Federal de 1988, prosseguiram os posicionamentos a respeito do tema.

Ricardo Lobo Torres, por exemplo, defende a teoria de que "o orçamento é lei formal, que apenas prevê as receitas públicas e autoriza os gastos, sem criar direitos subjetivos e sem modificar as leis tributárias e financeiras" ${ }^{, 774}$. O autor advoga a importância da distinção entre lei formal e lei material, pois isso visaria a "retirar da lei

${ }_{771}$ CAMPOS, Francisco, op. cit., p. 335.

${ }_{772}^{772}$ SILVA, José Afonso da. Orçamento-Programa no Brasil. São Paulo: Revista dos Tribunais, 1973, p. 272.

${ }^{773}$ Ibid., p. 275.

${ }^{774}$ TORRES, Ricardo Lobo. Tratado de Direito Constitucional Financeiro e Tributário: O orçamento na Constituição. $2^{\mathrm{a}}$ ed. Rio de Janeiro: Renovar, 2000, p.76. 
ânua qualquer conotação material relativamente à constituição de direitos subjetivos para terceiros, sem implicar perda de sua função de controle negativo do Executivo no que pertine aos limites do endividamento e das renúncias de receitas"775.

Para Kiyoshi Harada, a lei orçamentária "difere das demais leis, caracterizadas por serem genéricas, abstratas e constantes ou permanentes. Ela é, na verdade, uma lei de efeito concreto para vigorar por um prazo determinado de um ano, fato que, do ponto de vista material, retira-lhe o caráter de lei",776.

Marcos Nóbrega, igualmente, afirma que a teoria da lei formal se adapta com muito mais propriedade à nossa realidade. Em suas palavras,

o orçamento deve ser tratado como autorização, posto que a realidade econômica, as adversidades, a mudança do contexto no qual está inserida a execução orçamentária, e até mesmo a mudança de planos determinada pelo Governo podem ensejar a não execução de programas já contemplados nas peças orçamentárias ${ }^{777}$.

Por outro lado, Carlos Valder do Nascimento defende que "o orçamento tem um tratamento diferenciado no plano constitucional, caracterizando-se como uma lei especial de conteúdo determinado",778.

A seu turno, Regis Fernandes de Oliveira afirma que "se cuida de lei em sentido formal, consolidando posição ideológica governamental, que lhe imprime caráter programático",779. Todavia, o mesmo jurista defende, linhas adiante, "a nova concepção da lei orçamentária, como vinculativa da ação do Estado". Assim sendo, "as finalidades que forem inseridas na peça orçamentária deixam de ser mera ação governamental, mas identificam a solidez de compromissos com o cumprimento dos objetivos ali consignados",780.

Por sua vez, Celso Bastos e Ives Gandra da Silva Martins recusam validade à distinção, asseverando que o Orçamento "é um instrumento jurídico, pois apenas ganha forma e obriga quando aprovado nos termos do processo legislativo, tornando-se lei e tendo a eficácia de qualquer lei, ${ }^{781}$.

\footnotetext{
775 Ibid., p.76/77.

${ }^{776}$ HARADA, Kiyoshi. Direito Financeiro e Tributário. $15^{\mathrm{a}}$ ed. São Paulo: Atlas, 2006, p. 86.

777 NÓBREGA, Marcos. Lei de Responsabilidade Fiscal e Leis Orçamentárias. São Paulo: Juarez de Oliveira, 2002, p. 99.

${ }^{778}$ NASCIMENTO, Carlos Valder do. Curso de Direito Financeiro. Rio de Janeiro: Forense, 1999, p. 67.

${ }^{779}$ OLIVEIRA, Regis Fernandes de. Curso de Direito Financeiro. São Paulo: RT, 2006, p. 311.

${ }^{780}$ Ibid., p. 312.

${ }^{781}$ BASTOS, Celso; MARTINS, Ives Gandra da Silva. Comentários à Constituição do Brasil. Tomo II. Vol. $6.2^{\text {a }}$ ed. São Paulo: Saraiva, 2001, p. 199.
} 
Destarte, embora se perceba a existência de uma corrente doutrinária mais inclinada à tese da lei formal, não se pode deixar de reconhecer que, mesmo entre os autores brasileiros, sempre existiram aqueles que, diferentemente, defenderam o enquadramento da Lei de Orçamento como lei material.

Os autores mais modernos na doutrina estrangeira, contudo, se inclinam para o reforço à tese da Lei de Orçamento enquanto lei material, como, entre outros, Moncada, Canotilho, Álvaro Bereijo, Ingrosso, García Añoveros, Lapatza, Sainz de Bujanda, Fonrouge e Dino Jarach.

Ingrosso define a Lei orçamentária como "uma lei de organização, entendendo por tal não somente a que cria um órgão, mas que também disciplina seu funcionamento" Em suas próprias palavras: "es una ley de organización, la mayor entre las leyes de organización".

Em termos semelhantes, García Añoveros afirma que "a Lei orçamentária é a que dá impulso dinâmico à organização administrativa e a toda a organização do Estado; por isso, é complemento indiscutível das leis de organização" ${ }^{\text {"783. }}$.

Como destaca Canotilho, "a identificação da lei do orçamento com as leis de organização só está correcta no sentido que ela opera sobre a direcção e a actividade confiada aos órgãos de administração pública" ${ }^{, 784}$.

Rodrigues Bereijo também resguarda o caráter material da lei orçamentária:

Não vemos razão pela qual se tenha de negar seu caráter de lei material, pois sua eficácia substantiva com respeito aos órgãos do Estado (que hão de sujeitar sua atividade administrativa às normas que no caso tenham sido estabelecidas na Lei orçamentária) e com respeito aos particulares (cujas relações jurídicas com o Estado podem resultar modificadas pelas normas orçamentárias) é evidente ${ }^{785}$.

Cabral de Moncada, adicionalmente, se alinha entre aqueles que advogam a Lei Orçamentária como lei em sentido material:

Do mesmo passo o novo conteúdo do orçamento é susceptível de reforçar o entendimento da própria noção de lei do orçamento enquanto lei em sentido material ${ }^{786}$.

\footnotetext{
${ }^{782}$ INGROSSO, Gustavo apud SAINZ DE BUJANDA, Fernando, op. cit., p. 298.

${ }^{783}$ AÑOVEROS, García apud SAINZ DE BUJANDA, Fernando, op. cit., p. 299.

${ }^{784}$ CANOTILHO, José Joaquim Gomes, op. cit., p. 566/567.

785 BEREIJO, Álvaro Rodriguez. El presupuesto del Estado. Madrid: Tecnos, 1970, p. 163.

${ }^{786}$ MONCADA, Luís S. Cabral de. Perspectivas do Novo Direito Orçamental Português. In: Estudos de Direito Público. Coimbra Editora, 2001, p. 92/93.
} 
A importância essencial das matérias de que trata o orçamento do ponto de vista da conformação dos valores da comunidade faz dele um documento de especial dignidade jurídica que explica a sua pertinência ao domínio material da lei.

A noção material da lei sobre assim todo o âmbito da regulamentação dos valores essenciais da comunidade dentro do qual assume largo significado o orçamento. (...)

É por o acto de aprovação ser um acto de direcção política fundamental que ele é atribuído à competência reservada do Parlamento, o qual se vê assim associado à função de direcção política. A reserva parlamentar deve hoje em dia explicar-se não do estrito ponto de vista da protecção dos direitos subjectivos mas também e sobretudo do ponto de vista da participação na direcção estadual nas matérias mais relevantes segundo as particulares concepções axiológicas de cada sociedade ${ }^{787}$.

No mesmo prisma, para Canotilho e Vital Moreira,

O orçamento é portanto uma lei, mas uma lei dotada de regime específico, não apenas quanto à sua formação (reserva de iniciativa governamental, etc.) mas também quanto ao seu período de vigência (princípio da anualidade) e a outros aspectos. Todavia, fora as especificidades indicadas, a lei do orçamento é uma lei como as outras, podendo ser objecto de fiscalização preventiva da constitucionalidade e de veto político ou por inconstitucionalidade por parte do $\mathrm{PR}^{788}$.

E complementam a exposição, ratificando que:

A lei do orçamento é uma lei quer em sentido formal quer em sentido material, assumindo-se a Assembleia da República como órgão competente não só para aprovar a lei no plano formal, mas também para lhe determinar o conteúdo material ${ }^{789}$.

Para Fonrouge, a Lei de Orçamento "se trata de una ley perfecta, con efectos jurídicos normales" ${ }^{\text {790 }}$. Em relação a Sainz de Bujanda, é uma lei em sentido pleno, com múltiplos comandos:

podemos concluir que en nuestro Derecho la Ley de Presupuestos debe considerarse como una ley en sentido pleno, de contenido normativo. No solamente porque las normas presupuestarias que regulan la autorización de los gastos o la administración y gestión de los ingresos son verdaderas reglas de Derecho con efectos jurídicos generales, sino también porque en las Leyes de Presupuestos se contienen normas jurídicas de contenido muy diverso: normas que innovan o modifican el ordenamiento positivo, normas que contienen delegaciones o autorizaciones legislativas, normas que autorizan consignaciones de créditos en relación con gastos creados por otras normas legales sustantivas, etcétera. Contenido normativo que pone de manifiesto la eficacia material constitutiva o innovativa de la Ley de Presupuestos.

En nuestro Derecho positivo, la Ley de Presupuestos tiene todos los caracteres del valor y la fuerza de la ley: imposibilidad de que sus normas sean derogadas o modificadas por

${ }^{787}$ MONCADA, Luís S. Cabral de. Perspectivas do Novo Direito Orçamental Português. In: Estudos de Direito Público. Coimbra Editora, 2001, p. 94.

${ }^{788}$ CANOTILHO, J. J. Gomes; MOREIRA, Vital. Constituição da República Portuguesa Anotada. Vol. 1. $1^{\mathrm{a}}$ ed. brasileira/4 ${ }^{\text {a }}$ ed. portuguesa. São Paulo: Revista dos Tribunais e Coimbra Editora, 2007, p. 1116.

${ }^{789}$ Ibid., p. 1120.

${ }^{790}$ FONROUGE, Carlos M. Giuliani. Derecho Financiero. Vol. I. $3^{\mathrm{a}}$ ed. Buenos Aires: Depalma, 1977, p. 141. 
simples reglamentos y posibilidad de modificar o incluso derogar normas precedentes de igual o inferior rango. Contenido jurídico normativo que en muchos casos tiene carácter general y aun permanente. Así las cosas, no puede acogerse en nuestro Derecho la tesis que considera al Presupuesto como una ley en sentido formal ${ }^{791}$.

Segundo Lapatza,

o modo mais coerente de demonstrar a incoerência da tese formalista, é fazer ver de forma palpável que o orçamento contém normas jurídicas. Normas jurídicas que disciplinam a organização e normas jurídicas que disciplinam a atividade administrativa frente a terceiros e as relações jurídicas que dela derivam. ${ }^{792}$

É exatamente isso que os diversos autores ora colacionados fazem ver em suas exposições: a teoria da lei formal é insuficiente porque rechaça uma característica marcante do orçamento: a existência de preceito jurídico em seu conteúdo.

Considerando, todavia, que o correto enquadramento da Lei de Orçamento, em cada ordenamento jurídico, não pode prescindir da análise dos contornos que the foram conferidos, há que se proceder à referida investigação, retomando pontos e questões levantadas acerca dos pilares clássicos.

Como visto, existe uma pluralidade normativa dessa Lei, revelada por meio de autorizações, proibições e determinações contidos nos diversos elementos constitutivos da peça orçamentária. O principal conteúdo jurídico da Lei Orçamentária é a de vinculação aos fins a que se destina; destarte, as finalidades incorporadas à Lei de Orçamento se caracterizam por revelarem determinações dirigidas aos administradores públicos. Nesse sentido, os objetivos estratégicos, fiscais e programáticos incorporados à Lei de Orçamento se revestem de nítido cunho obrigatório.

Por outro lado, os meios utilizados para o alcance dos fins estabelecidos, consubstanciados nos limites financeiros dos créditos orçamentários - dotações -, não se revelam obrigatórios, visto que a multiplicidade e complexidade da realidade, além da necessidade de compatibilização dos vários objetivos, nem sempre harmônicos, impede que as dotações se revistam de cunho obrigatório. De qualquer forma, os limites financeiros incorporam um duplo comando: autorização e proibição. Autorização, ao facultarem a realização das despesas que permitirão o alcance dos objetivos traçados; e proibição, ao indicarem o limite de recursos passíveis de utilização.

\footnotetext{
791 SAINZ DE BUJANDA, Fernando. Lecciones de Derecho Financiero. $7^{\mathrm{a}}$ ed. Madrid: Universidad Complutense, 1989, p. 441.

${ }^{792}$ LAPATZA, José Juan Ferreiro. Curso de Derecho Financiero Español. 23 ${ }^{\mathrm{a}}$ ed. Madrid: Marcial Pons, 2003, v. I., p. 298.
} 
Além disso, todo o regramento estabelecido pelo Poder Legislativo referente às alterações do Orçamento e normatização dos créditos suplementares revela extenso rol de autorizações e proibições dirigidas a toda a Administração Pública no gerenciamento dos recursos orçamentários atribuídos aos seus órgãos e entidades.

Por outro lado, verificou-se que, a par das restrições constitucionais à atuação do Poder Legislativo, encontra-se o Parlamento, em nosso ordenamento, facultado à ampla discussão e alteração da proposta orçamentária, faculdade essa nitidamente contrária àquela conferida pela teoria clássica ou formal da Lei de Orçamento.

Quanto a isso, pode-se afirmar que a ampla capacidade de discussão e alteração da Lei de Orçamento, entre nós, já é, por si só, indicativa de que o Orçamento não se reveste da condição de mera lei formal. Afinal, como destaca Canotilho, "na hipótese de intervenção activa do Parlamento, parece já ser questionável a consideração da lei do orçamento como acto legislativo formal de aprovação"793.

O reforço e ampliação das funções parlamentares, nesse sentido, terminam por fundamentar o entendimento da Lei de Orçamento enquanto lei material. A reivindicação da necessária atuação parlamentar como elemento integrante para a definição da direção política do Governo é nota que sacramenta a inclusão da matéria orçamentária à deliberação legislativa e à submete aos contornos materiais da Lei.

Há que se registrar, ainda, a existência de sanções ao descumprimento da Lei de Orçamento, em franca dissonância à tese da lei formal. No ordenamento brasileiro, como visto, o núcleo sancionatório da lei orçamentária é extraído diretamente da fonte constitucional, revelando a importância desse diploma normativo.

Por último, salientou-se, logo de início, que, ao contrário do entendimento defendido pela teoria clássica, a Lei de Orçamento é um todo orgânico, cujos dispositivos e partes integrantes compõem um único diploma normativo. E a análise de seu conjunto revela a existência dos elementos destacados por Laband como necessários à caracterização da lei orçamentária enquanto lei material: ordem e proibição ${ }^{794}$.

A diferença é de que o acento colocado por Laband em relação a tais termos fazia referência aos aspectos formais da Lei de Orçamento, ou seja, das receitas e despesas previstas, na forma tradicionalmente estabelecida pelo Orçamento do século XIX. Contudo, considerando que o ordenamento jurídico brasileiro encampa e incorpora um

\footnotetext{
${ }^{793}$ CANOTILHO, José Joaquim Gomes. A Lei do Orçamento. In: Estudos em Homenagem ao Prof. Doutor J. J. Teixeira Ribeiro. Universidade de Coimbra: Boletim da Faculdade de Direito, Número Especial, 1979, p. $563 / 564$.

${ }^{794}$ LABAND, Paul, op. cit., p. 89/90.
} 
nítido viés de Orçamento por Resultados, a ordem e a proibição não podem ser averiguadas em relação a critérios formais de conformidade entre o previsto e o executado. A ordem e a proibição encontram-se, direta e inelutavelmente, associadas aos fins previstos na Lei de Orçamento.

Nas palavras de Canotilho,

Isto exigirá, como é óbvio, que se abandone a reiterada ideia de que a lei do orçamento é um simples cálculo ou previsão, uma obra de números juridicamente indiferente, para se passar a insistir na ideia de lei de aprovação como aplicação de meios financeiros à prossecução de certos fins, aplicação essa que não pode furtar-se à observância dos principios constitucionais e respectiva fiscalização pelos órgãos de controlo ${ }^{795}$.

Em síntese, utilizando-se da tradicional dicotomia da teoria do duplo conceito de lei, não há como, no ordenamento brasileiro, deixar de se defender que a Lei de Orçamento é uma lei material.

Isso, contudo, não impede que se reconheça as inúmeras peculiaridades da Lei de Orçamento, que representam a complexidade e nobreza de suas funções. Tais notas distintivas, todavia, não podem ser utilizadas para se diminuir seu relevo, ou para relegá-la ao plano de ato administrativo. Dessa forma, pode-se considerar, sem dúvida, a LOA como um ato legislativo sui generis, como destaca Canotilho:

Como quer que seja, mesmo que aceitemos a improcedência lógico-teorética do duplo conceito de lei e os condicionamentos político-constitucionais de tal doutrina, o que é certo é que a lei do orçamento continua a ser considerada como um acto legislativo sui generis $^{796}$.

Como destaca Moncada, "a lei é, nas sociedades democráticas e plurais de hoje, um instrumento do acordo político possível"797. Tal definição, com maior acerto, se presta a oferecer os contornos da Lei de Orçamento, que se caracteriza como o instrumento do acordo político entre Executivo e Legislativo para o direcionamento das atividades governamentais, emprestando-lhes os fins últimos de que se deve encarregar o Governo.

\footnotetext{
${ }^{795}$ CANOTILHO, José Joaquim Gomes, op. cit., p. 581.

796 Ibid., p. 553.

${ }^{797}$ MONCADA, Luís S. Cabral de. Direito público e eficácia. In: Estudos de Direito Público. [S.1]: Coimbra Editora, 2001, p. 210.
} 


\title{
4.12 A flexibilidade como elemento integrante da natureza da Lei de Orçamento
}

O princípio da flexibilidade irradia-se sobre a conformação que se procura conferir à Lei de Orçamento, e garante que os fins últimos que a orientam possam ser alcançados. Efetivamente, o enrijecimento artificial da Lei Orçamentária, por meio de vedações à sua alteração, antes que em seu fortalecimento, implica em sua fragilização, em face do descolamento progressivo da realidade em que pretende atuar. Afinal, como ressalta José Afonso da Silva, "A flexibilidade é um princípio fundamental do planejamento. Ora, se o orçamento-programa constitui uma etapa deste, é compreensível que se tenha a ele comunicado a regra" ${ }^{, 798}$.

O primeiro motivo que indica a necessidade de certa flexibilidade é a antecedência entre o período de formulação do plano e a época da efetiva execução do Orçamento, que termina por acarretar em inevitável descasamento entre a realidade superveniente e as previsões consignadas na Lei de Orçamento:

\begin{abstract}
Nem sempre as previsões podem captar todas as condições vigentes à época da execução, e não é possível programar de forma que a execução se ajuste completamente às previsões. A flexibilidade busca cumprir a programação em seu aspecto essencial, pelo que, muitas vezes ou quase sempre, se tem que modificar pormenores e fazer reajustamento nas previsões e programações orçamentárias no curso de sua execução. Para tanto, o próprio orçamento oferece mecanismo adequado ou o direito orçamentário permite tais ajustamentos nos limites que não importem desrespeito ao princípio da legalidade e do controle parlamentar em matéria financeira ${ }^{799}$.
\end{abstract}

Contudo, há uma série de outros motivos que indicam a necessidade de que seja conferida certa flexibilidade à Lei de Orçamento. Entre eles, sobressaem a de adaptação às novas situações, de que são exemplos a queda de arrecadação, as mudanças de conjunturas econômicas, fiscais ou financeiras; a de compatibilização entre os vários objetivos que a Lei de Orçamento pretende alcançar; as considerações em torno de princípios como da eficácia, eficiência, economicidade e efetividade; bem como as inevitáveis alterações das conjunturas mais imediatas de execução dos programas orçamentários, a exemplo de atrasos em obras, questões ambientais, lides e discussões jurídicas, procedimentos licitatórios, entre outras.

As considerações de eficácia, que progressivamente se amoldam à Lei de Orçamento, por implicarem em alteração do tradicional conteúdo normativo geral e

\footnotetext{
${ }^{798}$ SILVA, José Afonso da. Orçamento-Programa no Brasil. São Paulo: Revista dos Tribunais, 1973, p. 155. ${ }^{799}$ Ibid., p. 310/311.
} 
abstrato da lei, fortalecem a necessidade de se conferir certa flexibilidade aos contornos da peça orçamentária:

Assim é que a eficácia subentende uma modificação do próprio conteúdo legislativo, que há que tornar mais dúctil e maleável. A hipótese legislativa que vai condicionar a Administração deve apresentar-se como relativamente indeterminada, ao jeito da directiva, 'standard' ou 'guide-line', de modo a não precluir a adaptabilidade a novas situações, de que se falava atrás, e que está na razão directa da própria eficácia. Como problema legislativo a eficácia não requer apenas certa auto-contenção dos ímpetos regulamentadores do legislador, de que sempre a Administração acaba por beneficiar, em termos do alargamento do espaço de manobra que lhe assiste, requer também especiais cuidados no tratamento legislativo das matérias. Menos legislação, porventura, mas, seguramente, melhor legislação ${ }^{800}$.

E, em outras palavras, "a eficácia subentende hoje um permanente esforço de adaptação a uma conjuntura em rápida mudança à face da qual as certezas geram dúvidas, especialmente, mas não só, no âmbito da intervenção sócio-económica do Estado" ${ }^{801}$. .

De toda forma, o fato de ser necessária a conformação da atividade governamental por meio do parâmetro legal, implica a exigência de utilização da lei, e, em particular, da Lei de Orçamento, para o direcionamento da atução do Governo, pois, como destaca Manoel Gonçalves Ferreira Filho:

\begin{abstract}
Para promover a expansão da economia, é preciso um plano global. Ou seja, é indispensável que haja uma escolha de objetivos econômicos e o estabelecimento dos meios correspondentes, em termos coerentes. Pode não ser necessário explicitar essa escolha de objetivos e a determinação dos meios num documento formal, um plano, mas é intuitivo que, sem a escolha dos objetivos e dos meios feita de modo coerente, nenhuma tarefa, e muito menos o crescimento econômico, pode ser levada a cabo, com êxito.

Essa definição de objetivos e meios, no estado de direito, não pode ser consagrada a não ser na lei, para que possa produzir efeitos. Daí decorre que, embora caiba naturalmente ao governo essa tarefa, o planejamento só pode concretizar-se pelo processo de elaboração de leis ${ }^{802}$.
\end{abstract}

Portanto, haverá que se compatibilizar a necessidade da Lei com a introdução de certa flexibilidade, de forma que a lei possa cumprir com os próprios fins que lhe foram atribuídos. Exatamente por isso, Manoel Gonçalves Ferreira Filho destaca que as leis de impulsão ou leis instrumentais - de que é exemplo a Lei de Orçamento - devam ser flexíveis:

\footnotetext{
${ }^{800}$ MONCADA, Luís S. Cabral de. Direito público e eficácia. In: Estudos de Direito Público. [S.1]: Coimbra Editora, 2001, p. 175.

${ }^{801}$ Ibid., p. 205.

${ }^{802}$ FERREIRA FILHO, Manoel Gonçalves. Do Processo Legislativo. 6a ed. São Paulo: Saraiva, 2007, p. 273.
} 
(...) as leis de impulsão, para que sejam eficientes, devem ser flexíveis. Se não o forem, não poderá haver resposta pronta e adequada para as dificuldades oriundas de uma economia e de uma sociedade em rápida transformação, como é a atual. Sua alteração, destarte, há de ser fácil, para acompanhar a mudança das condições (...).

Nas leis instrumentais deve prevalecer a adequação aos fins, bem como a flexibilidade, em razão da mutabilidade das circunstâncias ${ }^{803}$.

Desse modo, as leis instrumentais visam, preponderantemente, "a uma impulsão no desenvolvimento econômico e social e, portanto, devem servir de instrumento para a ação de governo" ${ }^{\text {804 }}$.

Por conseguinte, as leis de impulsão, ao revelarem um caráter um caráter instrumental, servem de meios para o atingimento de certas metas. Nessa ótica, a lei orçamentária possui nítido caráter de ferramenta, de meio para o alcance dos objetivos que lhe orientam. Efetivamente, como destaca Ricardo Lobo Torres, "O orçamento vai buscar fora de si o seu objetivo, eis que visa a permitir a implementação de políticas públicas e a atualização dos programas e do planejamento governamental" ${ }^{\prime 85}$. Ou, em outras palavras:

O direito orçamentário, embora instrumental, não é insensível aos valores nem cego para com os princípios jurídicos. Apesar de não ser fundante de valores, o orçamento se move no ambiente axiológico, eis que profundamente marcado pelos valores éticos e jurídicos que impregnam as próprias políticas públicas ${ }^{806}$.

A flexibilidade, por outro lado, não significa uma ampla e desmedida possibilidade de alteração da Lei de Orçamento, visto que, ao contrário, visa a assegurar o cumprimento dos fins que lhe são íncitos. Não por outro motivo, a flexibilidade de que se encontra imbuída a Lei de Orçamento está balizada pelos contornos legais que a própria lei orçamentária traça em seu corpo normativo.

Por outro lado, a discricionariedade conferida para as alterações da Lei de Orçamento não representa livre margem de atuação para o administrador público, mas, ao contrário, poderes conferidos para o alcance das finalidades estabelecidas na própria Lei. Nas palavras de Bandeira de Mello:

a única razão lógica capaz de justificar a outorga de discrição reside em que não se considerou possível fixar, de antemão, qual seria o comportamento administrativo pretendido como imprescindivel e reputado capaz de assegurar, em todos os casos, a

\footnotetext{
${ }^{803}$ Ibid., p. 279.

${ }^{804}$ FERREIRA FILHO, Manoel Gonçalves, op. cit., p. 280.

805 TORRES, Ricardo Lobo. Tratado de Direito Constitucional Financeiro e Tributário. Vol. V. O Orçamento na Constituição. $2^{\mathrm{a}}$ ed. Rio de Janeiro: Renovar, 2000, p. 109.

${ }^{806}$ Ibid., p. 109.
} 
única solução prestante para atender com perfeição ao interesse público que inspirou a norma. Daí a outorga da discricionariedade $(\ldots)^{807}$.

Ainda em consonância às lições do doutrinador:

A valia do poder, a utilidade e o sentido dele, resumem-se em consistir em instrumento insuprimível, sem o qual o agente administrativo não teria como desincumbir-se desse dever posto a seu cargo: dever de concretizar a finalidade legal, isto é, dever de dar satisfação a um interesse de terceiro, a um interesse alheio; no caso, o interesse da coletividade. Logo, o administrador não dispõe de poderes-deveres, como às vezes se diz, mas de deveres-poderes ${ }^{808}$.

Uma vez que atividade administrativa é desempenho de função e dado que função é o cumprimento obrigatório do dever de atingir uma finalidade antecipadamente estabelecida através do manejo de poderes exercitáveis no interesse de outrem, e estabelecido que a lei sempre e sempre impõe, como é natural, o dever de buscar-se a medida que atenda de modo preciso sua finalidade, resulta certo que a liberdade administrativa acaso conferida por uma norma de direito não significa sempre liberdade de eleição entre indiferentes jurídicos. Não significa poder de opções livres, como as do direito privado. Significa o dever jurídico funcional (questão de legitimidade e não de mérito) de acertar, ante a configuração do caso concreto, a providência - isto é, o ato ideal, capaz de atingir com exatidão a finalidade da lei, dando, assim, satisfação ao interesse de terceiros - interesse coletivo e não do agente - tal como firmado na regra aplicanda $^{809}$.

Destarte, em face da necessidade de compatibilização de diferentes objetivos reclamando recursos financeiros e à vista da análise do caso concreto e do sopesamento da melhor medida a ser adotada, há que se manejar os limitados recursos financeiros para a maximização dos benefícios a serem garantidos à sociedade.

Tais considerações indicam como a flexibilidade é indissociável da própria natureza jurídica da Lei de Orçamento. Mais do que isso, ela representa o instrumento absolutamente indispensável à adaptação da atuação governamental em face das rápidas alterações da realidade, sem o que a LOA se tornaria instrumento obsoleto e imprestável à garantia dos próprios fins que visa alcançar.

Por último, reitere-se que a garantia do cumprimento da vontade do legislador diante da Lei de Orçamento há de ser, sempre, o alcance dos fins consignados na peça orçamentária. Afinal, é o alcance dos objetivos e metas fixados que dá a efetiva e real medida do cumprimento dos deveres estampados nessa Lei e não a impossibilidade de sua alteração formal. A alteração formal, por vezes, é absolutamente necessária para que o alcance dos fins se revele possível.

${ }^{807}$ BANDEIRA DE MELLO, Celso Antônio. Discricionariedade e Controle Jurisdicional. $2^{\mathrm{a}}$ ed., $7^{\mathrm{a}}$ tiragem. São Paulo: Malheiros, 2006, p. 33.

${ }^{808}$ Ibid., p. 54.

${ }^{809}$ Ibid., p. 47. 


\section{CONCLUSÕES}

Percorrido o itinerário previsto para o presente estudo, podem-se extrair, em apertada síntese, as seguintes conclusões:

1. A evolução histórica dos Orçamentos Públicos, ao acompanhar o desenvolvimento dos Estados modernos, ensejou a incorporação de novas e relevantes funções, que se somaram à função tradicional de controle político do Legislativo sobre o Executivo.

2. Entre as funções incorporadas à nova conformação dos Orçamentos Públicos, destacamse a instrumentalização administrativa ou gerencial, por meio da qual passam a refletir técnicas modernas de administração, com vistas ao gerenciamento dos resultados pretendidos pela ação governamental; e a instrumentalização fiscal, pela qual passam a consubstanciar e concretizar determinados fins de política fiscal do Governo.

3. A instrumentalização administrativa e gerencial das leis orçamentárias resultam na incorporação de critérios de eficiência, eficácia e efetividade na elaboração, execução e avaliação da Lei de Orçamento, bem como na mensuração dos resultados pretendidos pelos programas e políticas públicas implementados pelo Governo.

4. A instrumentalização fiscal da Lei de Orçamento implica em sua elaboração e execução em consonância com objetivos e metas fixados em termos da política fiscal pretendida pelo Governo, buscando-se mensurar o alcance das metas de resultado primário fixadas.

5. Existe uma tendência na configuração dos Orçamentos Públicos estrangeiros no sentido de implementação da concepção de Orçamento por Desempenho, procurando-se associar objetivos e metas ao processo alocativo, além de introdução de informações relativas à performance - indicadores de desempenho, custos e mensuração e avaliação de resultados -, e de uma tendência de estruturação dos Orçamentos em programas. Tais tendências realçam e reafirmam a instrumentalização gerencial e administrativa dos Orçamentos Públicos. 
6. Preocupações e objetivos de política fiscal também aparecem associados aos Orçamentos Públicos dos países abordados, seja por meio de anexos de estratégia fiscal associados à lei orçamentária, da associação de objetivos fiscais ao processo orçamentário, ou, ainda, por meio da previsão de leis e regras que incorporam mecanismos que garantam a sustentabilidade da despesa e a contenção de despesa em face de frustrações da receita.

7. Os ordenamentos jurídicos estrangeiros, de forma geral, definem as dotações como limites máximos disponibilizados ao Poder Executivo, não havendo obrigatoriedade de exaurimento dos recursos orçamentários.

8. A temática do Orçamento Mandatório ou Impositivo termina por lançar confusão ao exame da natureza jurídica da Lei de Orçamento visto que procura associar, a toda a lei orçamentária, um caráter meramente autorizativo. Contudo, ao fazer tal generalização termina por encobrir a existência de uma multiplicidade de comandos na Lei de Orçamento: autorizações, proibições e determinações. Esse equívoco se deve ao restrito objeto de exame, que se concentra, apenas, nas dotações orçamentárias. Estas, efetivamente, não enfeixam um cunho de obrigatoriedade, representando, antes, limites máximos disponibilizados às atividades do Poder Executivo.

9. A Lei de Orçamento é um todo orgânico, cujos dispositivos e partes integrantes compõem um único diploma normativo e, assim, somente pode revelar sua natureza jurídica enquanto considerada em sua totalidade. Todavia, existe uma pluralidade normativa na lei orçamentária, diante da existência de dispositivos com distintos conteúdos: autorizações, proibições e obrigações ou determinações.

10. O principal núcleo obrigatório das leis orçamentárias são os seus fins. Os fins orientam a estruturação das leis orçamentárias e lhes conferem direção e sentido, de modo que o administrador público fica vinculado ao alcance dos objetivos e metas fixados, devendo envidar os esforços necessários à plena desincumbência das tarefas que lhe foram cometidas.

11. No caso do Plano Plurianual (PPA), os fins assumem a forma de objetivos estratégicos, mais genéricos e orientadores da elaboração e execução da Lei de Diretrizes Orçamentárias 
(LDO) e da Lei Orçamentária Anual (LOA); no que se refere à LDO, os fins se consubstanciam em metas fiscais; por sua vez, na LOA, os fins assumem a forma de objetivos programáticos.

12. As metas fiscais, estabelecidas inicialmente na LDO, são concretizadas por meio da elaboração e execução da Lei de Orçamento. O projeto de LOA deve ser elaborado com vistas a estabelecer uma determinada proporção entre receitas e despesas primárias que assegure o alcance das metas fiscais. Todavia, não basta a mera elaboração em consonância às referidas metas. Durante todo o processo de execução orçamentária, há que se observar, inclusive quando da abertura de créditos adicionais, se as alterações efetuadas não prejudicam o alcance das metas fiscais estabelecidas.

13. A existência de metas bimestrais de arrecadação parece introduzir um elemento novo que não se encontra na legislação tributária permanente, uma vez que, se há metas a serem alcançadas, existe um nítido viés de obrigação ou esforço a ser despendido pelos órgãos arrecadadores no intuito do alcance dos objetivos anteriormente fixados.

14. A previsão orçamentária se constitui, em relação às despesas constitucionais ou legais obrigatórias na condição necessária para que aquelas despesas possam ser realizadas, em face de princípio constitucional expresso. Destarte, muito embora a Lei de Orçamento não seja, para tais espécies de despesas, o seu fundamento legal, a previsão orçamentária confere legitimidade à realização dos gastos.

15. Para as despesas discricionárias, a LOA se consubstanciaem seu fundamento legal primário, conferindo a possibilidade de que tais despesas possam ser efetivamente realizadas. Além disso, a previsão orçamentária, nesses casos, se constitui em elemento integrante e constitutivo da fonte geradora da obrigação, no caso, o contrato. Tais circunstâncias, em nosso ordenamento, indicam a insuficiência da tese de Jèze, que aponta, nessa circunstância, que o Orçamento seria um ato-condição.

16. As dotações orçamentárias conjugam, em nossa sistemática, dois comandos concomitantes: autorização e proibição. Autorização para a utilização de um certo volume 
de recursos na execução de determinada ação orçamentária e proibição de se exceder o teto de recursos consignados.

17. Os recursos financeiros representam os meios pelos quais se possibilitará o alcance dos objetivos fixados. Ou seja, existe uma nítida relação de função da dotação orçamentária, que somente existe em razão de um encargo ou atribuição conferida à Administração Pública.

18. Os objetivos e metas da Lei de Orçamento são obrigatórios, vinculando a Administração Pública ao seu alcance. Para a necessária mensuração dos resultados apresentados pelo Governo à frente da execução dos programas e do grau de cumprimento dos objetivos e metas, há que se considerar os resultados visados, enquanto indicações de direção e sentido, e, de forma mais imediata e concreta, os produtos e metas físicas obtidos na execução orçamentária.

19. Ao passo que os resultados - outcomes - devem nortear a ação pública, os produtos outputs - materializam o mais imediato e concreto resultado do desenvolvimento das atividades programáticas e, dessa forma, ensejam a aferição mais exata do grau de cumprimento da Lei de Orçamento.

20. Deve-se buscar a compatibilização de objetivos fiscais e programáticos. Ambos integram validamente o corpo da peça orçamentária, a fim de que as lógicas subjacentes a cada espécie não sejam necessariamente conflitantes, embora assim possam se revelar em determinadas circunstâncias.

21. Nosso ordenamento jurídico encontra-se devidamente coordenado, possibilitando que se busque a compatibilidade entre os vários objetivos. Isso não impede que ocorram conflitos, sejam verticais, entre objetivos de distintas leis orçamentárias, ou horizontais, entre objetivos de uma mesma peça orçamentária, a exemplo dos vários programas constantes da Lei Orçamentária Anual. Tais conflitos deverão ser enfrentados considerando-se princípios jurídicos como o da proporcionalidade e da razoabilidade, além de critérios como o da hierarquia de objetivos, por meio do qual, objetivos maiores devem prevalecer sobre objetivos menores. 
22. Relativamente aos créditos suplementares e suas alterações, a Lei de Orçamento inova o ordenamento jurídico, regulamentando a possibilidade de alterações, de acordo com a natureza e extensão previamente determinadas pelo Legislador. Há, nesse caso, o estabelecimento de regras de direito abstratas e impessoais, válidas para todos os órgãos da Administração Pública federal para o período de vigência da LOA, que devem, obrigatoriamente, ser observadas durante o processo de execução do Orçamento.

23. As regras fixadas na seção que trata da autorização para abertura de créditos suplementares consubstanciam, simultaneamente, uma autorização para suplementação de recursos, quando necessário, e uma proibição de movimentação ou alteração das dotações orçamentárias em níveis superiores àqueles dispostos pela Lei de Orçamento, ou em circunstâncias ou hipóteses diferentes do que aquelas taxativamente estabelecidas pelas regras.

24. A Lei de Orçamento condiciona diversas leis e atos administrativos, os quais somente adquirirão a vigência indispensável desde que tenham sido previstos ou contemplados pela LOA. Ademais, a previsão orçamentária integra os próprios contratos administrativos firmados pelo Poder Público, constituindo-se em elemento integrante necessário da fonte geradora da obrigação.

25. O papel do Legislativo no processo de discussão, aprovação e controle da execução da Lei de Orçamento ocupa posição central no debate acerca da respectiva natureza jurídica. . Efetivamente, a teoria da lei formal pode ser traduzida como uma tentativa deliberada de restringir os poderes enfeixados pelo Parlamento, conferindo-se ampla extensão às limitações impostas às Câmaras Legislativas no processo de alteração da Lei.

26. A par das restrições constitucionais à atuação do Poder Legislativo, encontra-se o Parlamento, em nosso ordenamento, facultado à ampla discussão e alteração da proposta orçamentária, tendência essa nitidamente contrária àquela conferida pela teoria clássica ou formal da Lei de Orçamento. 
27. Em nosso sistema orçamentário, são as obrigações a serem criadas pelo Estado que devem encontrar amparo na Lei de Orçamento, sem o que nascem irregulares e viciadas; ademais o pagamento de despesas sem previsão orçamentária não poderá ser realizado, nos termos previstos pelo art. 167, II, da Constituição Federal.

28. Entende-se cabível a reestimativa de receitas pelo Parlamento, desde que amparada em fundamentação sólida e transparente quanto aos motivos ensejadores dos erros ou omissões encontrados.

29. As despesas obrigatórias são consignadas na Lei de Orçamento enquanto estimativas; por isso, tanto o Poder Executivo quanto o Poder Legislativo se encontram no dever jurídico de aproximarem tais estimativas da realidade o máximo possível. Isso não impede, contudo, que possam ser realizados remanejamentos, de acordo com as previsões efetuadas, à exceção das vedações expressamente consignadas no texto constitucional pessoal e encargos, dívida pública e transferências constitucionais obrigatórias aos entes federativos.

30. O núcleo sancionatório da Lei Orçamentária é depreendido diretamente do texto constitucional, embora seja integrado por meio de edição de leis específicas que suprirão a impossibilidade de a própria Lei dar o tratamento às vedações de seus dispositivos. Portanto, as infrações à Lei de Orçamento são sancionadas por meio de dispositivos que, conquanto não integrem formalmente a peça orçamentária, representam uma espécie de extensão ou complementação de seu corpo normativo, reforçando-lhe a eficácia.

31. O descumprimento da Lei de Orçamento não se revela por aspectos formais ou de meras divergências entre previsões e execução, desde que autorizadas pelo Legislativo, visto que tais aspectos não dão conta do alcance das finalidades pretendidas pela execução do Orçamento.

32. O cumprimento da Lei de Orçamento se revela pelo grau de alcance dos objetivos e metas fixados em seu corpo, em seu aspecto essencial. Por sua vez, a medida do descumprimento da lei orçamentária somente poderá ser aferida pela verificação do grau de falhas em sua execução, pelo número de programas que não alcançaram as finalidades a 
que se propunham, pelo descumprimento das metas fiscais que orientavam a lei orçamentária e pelos resultados ineficientes e ineficazes alcançados.

33. A clássica abordagem dicotômica, que distingue entre lei formal e lei material, tem sido severamente criticada em nossos dias, seja pelo progressivo alargamento do conceito de lei no processo de transformação do Estado contemporâneo, pelo realce da convergência da lei a um critério formal, ou, ainda, pela incorporação de uma racionalidade de eficácia, fenômenos que realçaram a fragilidade da tradicional distinção. Entre nós, a paulatina modificação do entendimento da mais alta Corte de Justiça brasileira quanto ao cabimento e à fiscalização da constitucionalidade da Lei de Orçamento também aponta nesse sentido.

34. O reforço e ampliação das funções parlamentares terminam por fundamentar o entendimento da Lei de Orçamento enquanto lei material. A reivindicação da atuação parlamentar como elemento integrante para a definição da direção política do Governo é nota que sacramenta a inclusão da matéria orçamentária à deliberação legislativa e à submete aos contornos materiais da Lei.

35. Utilizando-se da tradicional dicotomia da teoria do duplo conceito de lei, não há como, no ordenamento brasileiro, deixar de se defender que a Lei de Orçamento é uma lei material.

36. O princípio da flexibilidade irradia-se sobre a conformação que se procura conferir à Lei de Orçamento, e garante que os fins últimos que a orientam possam ser alcançados. Efetivamente, o enrijecimento artificial da Lei Orçamentária, por meio de vedações à sua alteração, antes que em seu fortalecimento, implica em sua fragilização, em face do descolamento progressivo da realidade em que pretende atuar.

37. A flexibilidade é indissociável da própria natureza jurídica da Lei de Orçamento. Mais do que isso, ela representa o instrumento absolutamente indispensável à adaptação da atuação governamental diante das rápidas alterações da realidade, sem o que a Lei de Orçamento se tornaria instrumento obsoleto e imprestável à garantia dos próprios fins que visa alcançar. 
38. Os recursos financeiros são os meios que permitem o alcance dos fins, contudo, são os fins que são obrigatórios. Destarte, a denominação lei de meios põe ênfase naquilo que não indica a real natureza da Lei de Orçamento. As LOAs são leis de fins e, dessa forma, a medida do seu cumprimento somente se revela em face do alcance dos objetivos que se lhe encontram associados. 


\section{REFERÊNCIAS BIBLIOGRÁFICAS}

AFONSO, José Roberto R.; BARROSO, Rafael. Uma Reforma Esquecida. In: Boletim de Desenvolvimento Fiscal $n^{\circ} 05$ - IPEA - Instituto de Pesquisa Econômica Aplicada. Jun. 2007.

ALBUQUERQUE, Claudiano; MEDEIROS, Márcio; FEIJÓ, Paulo Henrique. Gestão de Finanças Públicas. 2a ed. Brasília: Editor Paulo Henrique Feijó da Silva, 2008.

ALVES PINTO, Márcio Percival; BIASOTO JR., Geraldo (orgs.). Política Fiscal e Desenvolvimento no Brasil. Campinas: Editora da Unicamp, 2006.

AZEVEDO, Álvaro Villaça. Teoria Geral das Obrigações e Responsabilidade Civil. 11 ${ }^{\mathrm{a}}$ ed. São Paulo: Atlas, 2008.

BALEEIRO, Aliomar. Uma Introdução à Ciência das Finanças. 12a ed. Rio de Janeiro: Forense, 1978.

. Uma Introdução à Ciência das Finanças. $15^{\mathrm{a}}$ ed. Rio de Janeiro: Forense, 1998.

Uma Introdução à Ciência das Finanças. Atual. por Dejalma de Campos. 16 ed. Rio de Janeiro: Forense, 2006.

BANDEIRA DE MELLO, Celso Antônio. Discricionariedade e Controle Jurisdicional. $2^{\mathrm{a}}$ ed. São Paulo: Malheiros, 2006.

Curso de Direito Administrativo. $20^{\mathrm{a}}$ ed., rev. atual. São Paulo:

Malheiros, 2006.

BARROS JÚNIOR, Carlos Schmitt de. Orçamento - Natureza Jurídica. RDA 83/404.

BASTOS, Celso Ribeiro; MARTINS, Ives Gandra da Silva. Comentários à Constituição do Brasil. V. 6, T. II. $2^{\text {a }}$ ed. atual. São Paulo: Saraiva, 2001,

BERCOVICI, Gilberto. Constituição Econômica e Desenvolvimento. São Paulo: Malheiros, 2005.

BEREIJO, Álvaro Rodrigues. El presupuesto del Estado. Madrid: Tecnos, 1970.

. Orçamento I. Revista de Direito Público nº 94, abr./jun. 1990.

. Orçamento II. Revista de Direito Público nº 95, jul./set. 1990.

. Orçamento III. Revista de Direito Público nº 96, out./dez 1990.

BLÖNDAL, Jón R.; KRAAN, Dirk-Jan; RUFFNER, Michael. Budgeting in the United States. OECD Journal on Budgeting. V. 3, n. 2, 2003. 
BLÖNDAL, Jón R.; CURRISTINE, Teresa. Budgeting in Chile. OECD Journal on Budgeting. V. 4, n. 02, 2004.

BRESSER PEREIRA, Luiz Carlos. Reforma do Estado para a Cidadania. Brasília: ENAP - Escola Nacional de Administração Pública, 1998.

BRESSER PEREIRA, Luiz Carlos; SPINK, Peter. (orgs.). Reforma do Estado e Administração Pública Gerencial. 6ª ed. Rio de Janeiro: Editora FGV, 2005.

BOBBIO, Norberto. O Positivismo Jurídico. São Paulo: Ícone, 1999.

BURKHEAD, Jesse. Orçamento Público. Rio de Janeiro: Fundação Gatúlio Vargas, 1971.

CAMPOS, Dejalma de. Direito Financeiro e Orçamentário. $4^{\mathrm{a}}$ ed. São Paulo: Atlas, 2006.

CAMPOS, Francisco. Orçamento - Natureza Jurídica. RDA 71/324, jan./mar. 1963.

CANOTILHO, José Joaquim Gomes. A Lei do Orçamento. In Estudos em Homenagem ao Prof. Doutor J. J. Teixeira Ribeiro. Universidade de Coimbra: Boletim da Faculdade de Direito, Número Especial, 1979.

CANOTILHO, J. J. Gomes; MOREIRA, Vital. Constituição da República Portuguesa Anotada. Vol. 1. $1^{\text {a }}$ ed. brasileira/4 $4^{\mathrm{a}}$ ed. portuguesa. São Paulo: Revista dos Tribunais e Coimbra Editora, 2007.

CARVALHO, Kildare Gonçalves. Direito Constitucional. 12a ed., rev. atual. ampl. Belo Horizonte: Del Rey, 2006.

CHIAVENATO, Idalberto. Introdução à Teoria Geral da Administração. $7^{\mathrm{a}}$ ed. Rio de Janeiro: Elsevier, 2003.

CONTI, José Maurício. Direito Financeiro na Constituição de 1988. São Paulo: Oliveira Mendes: 1998.

. Federalismo Fiscal e Fundos de Participação. São Paulo: Juarez de Oliveira, 2001.

A Autonomia Financeira do Poder Judiciário. São Paulo: MP Editora, 2006.

(coord.) Orçamentos Públicos - A Lei 4.320/1964 comentada. São Paulo:

Revista dos Tribunais, 2009.

DECOMAIN, Pedro Roberto. Tribunais de Contas no Brasil. São Paulo: Dialética, 2006.

DEODATO, Alberto. Manual de Ciência das Finanças. 20ª ed. São Paulo: Saraiva, 1984.

DI PIETRO, Maria Sylvia Zanella. Direito Administrativo. 19a ed. São Paulo: Atlas, 2006.

DUGUIT, Léon. Traité de Droit Constitutionnel. Deuxième Édition. Tome IV. Paris: Ancienne Librairie Fontemoing \& Cie. Éditeurs, 1924. 
FARIA, Edimur Ferreira de. Curso de Direito Administrativo Positivo. $6^{\text {a }}$ ed. Belo Horizonte: Del Rey, 2007.

FERREIRA FILHO, Manoel Gonçalves. Curso de Direito Constitucional. 32 a ed. rev. atual. São Paulo: Saraiva, 2006.

Do Processo Legislativo. $6^{\text {a }}$ ed. São Paulo: Saraiva, 2007.

FIGUEIREDO, Argelina Cheibub; LIMONGI, Fernando. Incentivos Eleitorais, Partidos e Política Orçamentária. DADOS - Revista de Ciências Sociais, Rio de Janeiro, v. 45, n. 2, 2002.

- Processo Orçamentário e Comportamento Legislativo:

Emendas Individuais, Apoio ao Executivo e Programas de Governo. DADOS Revista de Ciências Sociais, Rio de Janeiro, v. 48, n. 4, 2005.

FILELLINI, Alfredo. Economia do Setor Público. São Paulo: Atlas, 1994.

FREIRE, Fátima de Souza; MONTEIRO, André Jalles; VIEIRA, Luiz Mário, et al. Finanças Públicas Municipais - Indicadores de Desempenho Fiscal do Nordeste Brasileiro. Fortaleza: Editora Universidade Federal do Ceará, 2007.

FONROUGE, Carlos M. Giuliani. Derecho Financiero. Vol. I. $3^{\text {a }}$ ed., ampl. atual. Buenos Aires: Depalma, 1977.

GIACOMONI, James. Orçamento Público. 13a ed. São Paulo: Atlas, 2005. . Orçamento Público. 14 ed. São Paulo: Atlas, 2007.

GIACOMONI, James; PAGNUSSAT, José Luiz (Orgs.). Planejamento e Orçamento Governamental - Coletânea 1. Brasília: Escola Nacional de Administração Pública ENAP, 2006.

GIAMBIAGI, Fabio; ALÉM, Ana Cláudia. Finanças Públicas. 2ª ed., rev., atual. Rio de Janeiro: Campus, 2001. . Finanças Públicas - Teoria e Prática no Brasil. $3^{\mathrm{a}}$ ed. São Paulo: Campus/Elsevier, 2008.

GREMAUD, Amaury Patrick; VASCONCELLOS, Marco Antonio Sandoval de; TONETO JÚNIOR, Rudinei. Economia Brasileira Contemporânea. $7^{\mathrm{a}}$ ed. São Paulo: Atlas, 2007.

GUERRA, Evandro Martins. Os controles externo e interno da Administração Pública. $2^{\mathrm{a}}$ ed. Belo Horizonte: Fórum, 2005.

HARADA, Kiyoshi. Direito Financeiro e Tributário. 15ª ed. São Paulo: Atlas, 2006. 
HORVATH, Estevão; OLIVEIRA, Regis Fernandes de. Manual de Direito Financeiro. $3^{\mathrm{a}}$ ed. São Paulo: RT, 2000.

JANNUZZI, Paulo de Martino. Indicadores para diagnóstico, monitoramento e avaliação de programas sociais no Brasil. Revista do Serviço Público: Brasília 56 (2): 137 160. abr/jun 2005.

JARACH, Dino. Finanzas Públicas y Derecho Tributario. Tercera edición - reimpresión. Buenos Aires: Abeledo-Perrot, 1996.

JÈZE, Gaston. Cours de Science des Finances et de Législation Financière Française. Sixième Édition. Paris: Marcel Giard, 1922.

. Principios Generales del Derecho Administrativo. Tomo IV. Traducción directa de la $3^{\text {a }}$ edición francesa, por Julio N. San Millán Almagro. Buenos Aires: Editorial Depalma, 1950.

KELSEN, Hans. Teoria Geral do Direito e do Estado. (trad. Luís Carlos Borges). $4^{\mathrm{a}}$ ed. São Paulo: Martins Fontes, 2005.

LABAND, Paul. Derecho Presupuestario. Trad. Jose Zamit. Madrid: Instituto de Estudios Fiscales, 1979.

LAPATZA, José Juan Ferreiro. Curso de Derecho Financiero Español. $23^{\mathrm{a}}$ ed. Madrid: Marcial Pons, 2003, v. I.

LOPREATO, Francisco Luiz Cazeiro. O colapso das finanças estaduais e a crise da federação. São Paulo: Editora Unesp, 2002.

MABARAK CERECEDO, Doricela. Derecho Financiero Público. $3^{\mathrm{a}}$ ed. México: McGraw-Hill Interamericana, 2007.

MACHADO Jr., J. Teixeira; REIS, Heraldo da Costa. A Lei 4.320/64 Comentada e a Lei de Responsabilidade Fiscal. $31^{\mathrm{a}}$ ed. Rio de Janeiro: IBAM, 2002/2003.

MACHADO SEGUNDO, Hugo de Brito. Contribuições e Federalismo. São Paulo: Dialética, 2005.

MARTINS, Ives Gandra da Silva; NASCIMENTO, Carlos Valder (coords.). Comentários à Lei de Responsabilidade Fiscal. $2^{\mathrm{a}}$ ed., rev. atual. São Paulo: Saraiva, 2007.

MATIAS-PEREIRA, José. Finanças Públicas - A Política Orçamentária no Brasil. São Paulo: Atlas, 2006.

MEDAUAR, Odete. O Direito Administrativo em Evolução. $2^{\mathrm{a}}$ ed. São Paulo: Editora Revista dos Tribunais, 2003. 
MEIRELLES, Hely Lopes. Direito Administrativo Brasileiro. $29^{\mathrm{a}}$ ed. São Paulo: Malheiros, 2004.

. Direito Municipal Brasileiro. Atual. por Márcio Schneider Reis e Edgard Neves da Silva. 14 ${ }^{\text {a }}$ ed. São Paulo: Malheiros, 2006.

MENDES, Marcos (org.). Gasto Público Eficiente - 91 Propostas para o Desenvolvimento do Brasil. Rio de Janeiro: Topbooks, 2006.

MENDONÇA, Félix. A Dívida Pública Brasileira. Brasília: Plenarium, 2005.

MELO, José Eduardo Soares de. Contribuições Sociais no Sistema Tributário. $5^{\mathrm{a}}$ ed. rev. atual. ampl. São Paulo: Malheiros, 2006.

MILESKI, Helio Saul. O Controle da Gestão Pública. São Paulo: RT, 2003.

MONCADA, Luís S. Cabral de. Estudos de Direito Público. [S.1]: Coimbra Editora, 2001.

MONTESQUIEU, Charles de Secondat. O Espírito das Leis. Trad. Cristina Murachco. $3^{\text {a }}$ ed. São Paulo: Martins Fontes, 2005.

MORAES, Alexandre de. Direito Constitucional. 22 a ed. São Paulo: Atlas, 2007.

NADER, Paulo. Curso de Direito Civil. Vol. 3. Contratos. $4^{\mathrm{a}}$ ed. Rio de Janeiro: Forense, 2009.

NASCIMENTO, Carlos Valder do. Curso de Direito Financeiro. Rio de Janeiro: Forense, 1999.

NÓBREGA, Mailson; AMADEO, Edward; LOYOLA, Gustavo et al. Idéias para salvar o orçamento. Tendências Consultoria Integrada, 2002.

NÓBREGA, Marcos. Lei de Responsabilidade Fiscal e Leis Orçamentárias. São Paulo: Juarez de Oliveira, 2002.

NUNES, Edson. A Gramática Política do Brasil. Brasília: Escola Nacional de Administração Pública, 1997.

NUNES, Selene Peres P. A Revisão da Lei $n^{o} 4.320 / 1964$ no contexto da Lei de Responsabilidade Fiscal. In Boletim de Desenvolvimento Fiscal $n^{\circ} 05$ - IPEA Instituto de Pesquisa Econômica Aplicada. Jun. 2007.

OECD Journal on Budgeting. Special Issue. The Legal Framework for Budget Systems. An Internacional Comparison. V. 4, n. 3, 2004.

OLIVEIRA, Gustavo Justino de. Contrato de Gestão. São Paulo: Editora Revista dos Tribunais, 2008.

OLIVEIRA, Regis Fernandes de. Curso de Direito Financeiro. São Paulo: Revista dos Tribunais, 2006. 
PEREIRA, Carlos; MUELLER, Bernardo. Comportamento Estratégico em Presidencialismo de Coalizão: As Relações entre Executivo e Legislativo na Elaboração do Orçamento Brasileiro. DADOS - Revista de Ciências Sociais, Rio de Janeiro, v. 45, n. 2, 2002.

PETRUCCI, Vera; SCHWARZ, Letícia. (orgs.). Administração Pública Gerencial: a reforma de 1995. Brasília: Editora Universidade de Brasília, 1999.

PIMENTA, Paulo Roberto Lyrio. Eficácia e aplicabilidade das normas constitucionais programáticas. Salvador: Max Limonad, 1999.

POLLITT, Christopher; BOUCKAERT, Geert. Avaliando reformas da gestão pública: uma perspectiva internacional. ENAP - Escola Nacional de Administração Pública. Revista do Serviço Público. Ano 53. Número 3. Jul-Set. 2002.

REALE, Miguel. Filosofia do Direito. 20a ed. São Paulo: Saraiva, 2009.

REZENDE, Fernando; CUNHA, Armando (coords.). Contribuintes e Cidadãos compreendendo o Orçamento Federal. Rio de Janeiro: FGV, 2002.

. Disciplina fiscal e qualidade do gasto público - Fundamentos da Reforma Orçamentária. Rio de Janeiro: Editora FGV, 2005.

ROCHA, Valdir de Oliveira (coord.). Aspectos Relevantes da Lei de Responsabilidade Fiscal. São Paulo: Dialética, 2001.

SABBAG, César. Orçamento e Desenvolvimento. Campinas: Millennium Editora, 2007.

SAINZ DE BUJANDA, Fernando. Lecciones de Derecho Financiero. $7^{\mathrm{a}}$ ed. Madrid: Universidad Complutense, 1989.

SALDAÑA, Adalberto. Teoria y Practica del Presupuesto por Programas en Mexico. Campestre Churubusco: Instituto Nacional de Administración Pública, 1977.

SCAFF, Fernando Facury. Direitos Humanos e a Desvinculação das Receitas da União DRU. RDA 236/33, abr./jun. 2004.

SCHICK, Allen. La presupuestación tiene algún futuro? Serie Gestión Pública $n^{\circ} 21$. Traducción de Varinia Tromben y revisión final de Ricardo Martner. Naciones Unidas. Instituto Latinoamericano y del Caribe de Planificación Económica y Social (ILPES): Chile, maio/2002. . The Performing State: Reflection on an Idea Whose Time Has Come but Whose Implementation has not. OECD Journal on Budgeting. V. 3, n. 2, 2003.

SEIXAS FILHO, Aurélio Pitanga. Limites Orçamentários da Administração Pública. In: Cadernos de Direito Tributário e Finanças Públicas. RT, ano 1, n. 4, jul./set. 1993. 
SERRA, José. Orçamento no Brasil. $2^{\text {a }}$ ed. São Paulo: Atual, 1994.

SHEA, Robert. J. Performance Budgeting in the United States. OECD Journal on Budgeting. V. 8, n. 1, 2008.

SILVA, José Afonso da. Orçamento-Programa no Brasil. São Paulo: Revista dos Tribunais, 1973. Aplicabilidade das Normas Constitucionais. $6^{\text {a }}$ ed. São Paulo: Malheiros, 2004. Curso de Direito Constitucional Positivo. $26^{\mathrm{a}}$ ed. rev. atual. São Paulo: Malheiros, 2006.

SOUSA, Alfredo José de; FRANCO, António de Sousa; BRITTO, Carlos Ayres et al. $O$ Novo Tribunal de Contas - Órgão Protetor dos Direitos Fundamentais. $3^{\mathrm{a}}$ ed. rev. ampl. Belo Horizonte: Fórum, 2005.

SOUSA FRANCO, António Luciano de. Manual de Finanças Públicas e Direito Financeiro. Lisboa: Faculdade de Direito de Lisboa, v. I, 1974.

TORRES, Ricardo Lobo. Tratado de Direito Constitucional Financeiro e Tributário. Vol. V. O Orçamento na Constituição. $2^{\mathrm{a}}$ ed. Rio de Janeiro: Renovar, 2000.

VASCONCELLOS, Marco Antonio Sandoval de; TROSTER, Roberto Luis. Economia Básica. $4^{a}$ ed. São Paulo: Atlas, 1998.

VENOSA, Sílvio de Salvo. Direito Civil: parte geral. 4ª ed. São Paulo: Atlas, 2004.

VIANA, Arizio de. Orçamento Brasileiro. $2^{a}$ ed. Rio de Janeiro: Financeiras, 1950.

VILLEGAS, Héctor B. Curso de Finanzas, Derecho Financiero y Tributario. Buenos Aires: Depalma, 1972.

\section{Documentos eletrônicos}

ALMEIDA, António Júlio; NEROSKY, Luiz Carlos. Diagnóstico do Processo Orçamentário Federal e Propostas de Medidas de Reforma - Modelos Orçamentários em outros Países. Ministério do Planejamento - Secretaria de Orçamento Federal. Brasília, maio/junho 2006, p. 37/38. Disponível em [https://www.portalsof.planejamento.gov.br/bib/Estudos/Modelos_Orcamentarios_e m_Outros_Paises.pdf]. Acesso em 20.05.2009. 
AFONSO, José Roberto Rodrigues. Memória da Assembléia Constituinte de 1987/88: As Finanças Públicas. Texto disponível no site http://www.federativo.bndes.gov.br/f_estudo.htm [acesso em 28.10.06]

CHILE. Ministerio de Hacienda. Dirección de Presupuestos. El proceso presupuestario en Chile, Aspectos generales: Marco Legal, Actores Institucionales, Principales Aspectos de Modernización, septiembre, 2005. Disponível em [http://www.dipres.cl/572/articles-22542_doc_pdf.pdf]. Acesso em 20.10.08. - Instrucciones del Formulario e Presentácion de Programas al Presupuesto. Disponível em [http://www.dipres.cl/572/articles-37391_doc_pdf.pdf]. Acesso em 22.05.09.

. Metodologia para elaboração de Matriz de Marco Lógico. Disponível em [http://www.dipres.cl/572/articles-37369_doc_pdf.pdf]. Acesso em 01.06.09. - Informe de Finanzas Públicas. Proyecto de Ley de Presupuestos del Sector Público para el año 2009. Octubre 2008. Disponível em [http://www.dipres.cl/572/articles-41339_doc_pdf.pdf]. Acesso em 22.05.09.

CONGRESSO NACIONAL. Comissão Mista de Planos, Orçamentos Públicos e Fiscalização. Reforma Orçamentária. Sugestões apresentadas pelo Presidente da CMO Deputado Paulo Bernardo relacionadas ao aprimoramento do processo orçamentário, 01 de março de 2005. Disponível em [http://www.forumfbo.org.br/media/reforma\%20or\%C3\%A7ament\%C3\%A1ria.doc]. Acesso em 27.08.2009.

GRAÇA, Luís Otávio Barroso da. Orçamento Impositivo: uma análise à luz da Economia Política. Dissertação apresentada ao Departamento de Economia da Universidade de Brasília, $2003 . \quad$ Disponível em [http://www2.senado.gov.br/bdsf/bitstream/id/88438/1/Or\%c3\%a7amento\%20imposi tivo.pdf]. Acesso em 24.06.2009.

MINISTÉRIO DA FAZENDA. Secretaria de Política Econômica. Dados Diversos da Política Fiscal. [acesso em 17.10.06] Disponível no site: http://www.fazenda.gov.br/spe/publicacoes/fiscal/bancodeslides/02\%20net-fiscal.pdf MINISTÉRIO DO PLANEJAMENTO, ORÇAMENTO E GESTÃO. Secretaria de Orçamento Federal. Vinculações de Receitas dos Orçamentos Fiscal e da Seguridade Social e o Poder Discricionário de Alocação dos Recursos do Governo Federal. Brasília. Fevereiro de 2003. Disponível no site: 
http://www.planejamento.gov.br/arquivos_down/sof/Vinculacoes_Consolidado.pdf $\quad\left[\begin{array}{ll}\text { acesso em } \\ \mathrm{en}\end{array}\right.$ $17.10 .06]$ . Manual Técnico de Orçamento - MTO 2009. Brasília, 2008. . Lei 11.897, de 30.12.2008 (LOA de 2009). Volume IV - Detalhamento das Ações - Órgãos do Poder Executivo (exclusive Ministério da Educação). Disponível em [https://www.portalsof.planejamento.gov.br/sof/2009/VOL_IV.pdf]. Acesso em 01.09.2009.

$\begin{array}{llll}\text { orçamentária } & \text { e } & \text { financeira). } & \text { Disponível }\end{array}$ [https://www.portalsof.planejamento.gov.br/bib/legislacao/decretos/Anexo_Decreto_ de_280109.pdf ]. Acesso em 08.10.09.

MINISTÉRIO DO PLANEJAMENTO, ORÇAMENTO E GESTÃO. Secretaria de Planejamento e Investimentos Estratégicos. Manual de Avaliação Plano Plurianual 2008/2011. Brasília, 2009.

NÓBREGA, Má1lson da. Orçamento já é impositivo. Artigo publicado no Jornal O Globo. Disponível em [http://oglobo.globo.com/pais/noblat/post.asp?cod_Post=60567\&a=112]. Acesso em 24.06.2009.

OLIVEIRA, Regis Fernandes de. Deve o Orçamento ser Cumprido?. Jus Navigandi, Teresina, ano 9, n. 672, 8 maio 2005. Disponível em: <http://jus2.uol.com.br/doutrina/texto.asp?id=6698>. Acesso em: 28 ago. 2009.

PEREIRA, Carlos; MUELLER, Bernardo. Strategic Behavior in a Coalition-Based Presidential System: Executive-Legislative Relations in the Budgetary Process in Brazil. Dados., Rio de Janeiro, v. 45, n. 2, 2002. Available from: $<$ http://www.scielo.br/scielo.php?script=sci_arttext\&pid=S0011$52582002000200004 \& \operatorname{lng}=$ en\&nrm=iso $>$. Access on: 29 Oct 2006 . doi: 10.1590/S0011-52582002000200004.

PORTUGAL. Ministério das Finanças e da Administração Pública. Direcção-Geral do Orçamento. Avaliação do Processo Orçamental em Portugal - Relatório da OCDE. Disponível em: [http://www.dgo.pt/oe/OCDE2008/OCDE2008_AvaliacaoProcessoOrcamentalEmPo rtgual.pdf]. Acesso em 17.07.09. Texto originalmente publicado em língua inglesa 
pela OCDE com o título: Budgeting in Portugal por Teresa Curristine, Chung-Keun Park e Richard Emery, 2008.

SENADO FEDERAL. Proposta de Emenda à Constituição $n^{\circ} 22$, de 2000. Disponível em [http://www.senado.gov.br/sf/atividade/materia/getPDF.asp?t=41011] Acesso em 25.06.2009.

Justificação da Proposta de Emenda à Constituição $n^{o}$ 22, de 2000.

Disponível em [http://www.senado.gov.br/sf/atividade/materia/getPDF.asp?t=41011] Acesso em 25.06.2009.

. Proposta de Emenda à Constituição $n^{o}$ 28, de 2000. Disponível em [http://www.senado.gov.br/sf/atividade/materia/getPDF.asp?t=40794]. Acesso em 24.06.2009.

. Exposição justificativa do Senador Paulo Paim constante da PEC $n^{\circ} 24$,

de 2003. Disponível em

[http://www.senado.gov.br/sf/atividade/materia/getPDF.asp?t=39195] Acesso em 24.06.2009.

Parecer $n^{o}$ 1.061, de 08.10.2008, da Comissão de Constituição, Justiça e Cidadania, referente à PEC $n^{o}$ 24/2003. Arquivo disponível em [http://www.senado.gov.br/sf/atividade/materia/getPDF.asp?t=22277]. Acesso em 24.06.2009.

TOLLINI, Helio. Em Busca de uma Participação mais Efetiva do Congresso no Processo de Elaboração Orçamentária. Maio/2008. Disponível em [http://apache.camara.gov.br/portal/arquivos/Camara/internet/orcamentobrasil/orcam entouniao/estudos/2008/2\%20Em\%20Busca\%20de\%20uma\%20Participa\%C3\%A7 \%C3\%A3o\%20mais\%20Efetiva\%20do\%20Congresso\%20no\%20\%E2\%80\%A6.pdf] . Acesso em 25.06.2009.

TRIBUNAL DE CONTAS DA UNIÃO - TC-009.509/2004-7 - Representação acerca da execução de emendas de autoria de membros do Congresso Nacional ao Orçamento Geral da União. Disponível em [http://www.tcu.gov.br/Consultas/Juris/Docs/judoc/Acord/20071004/TC-009-5092004-7.doc]. Acesso em 08.06.2009.

UNITED STATES. Committee on the Budget United States Senate. The Congressional Budget Process - An Explanation. U. S. Government Printing Office: Washington, 
1998. Disponível em [http://budget.senate.gov/democratic/the_budget_process.pdf]. Acesso em 17.07.2009.

\title{
Sites consultados
}

\author{
Nacionais \\ www.bndes.gov.br \\ www.cgu.gov.br \\ www.camara.gov.br \\ www.fazenda.gov.br \\ www.ipea.gov.br \\ www.ibge.gov.br \\ www.planalto.gov.br \\ www.planejamento.gov.br \\ www.portalsof.planejamento.gov.br \\ www.scielo.br \\ www.senado.gov.br \\ www.stf.gov.br \\ www.stn.fazenda.gov.br \\ www.tcu.gov.br
}

\section{Organismos Internacionais}

www.un.org

www.oecd.org

www.cepal.org

www.cepal.org/ilpes

www.imf.org

www.worldbank.org

\section{Chile}

www. dipres.cl

www.minhda.cl

www.ben.cl

www.camara.cl 
www.senado.cl

\section{Estados Unidos}

www.budget.senate.gov

www.ustreas.gov

www.whitehouse.gov

www.whitehouse.gov/omb

www.expectmore.gov

\section{França}

www.assemblee-nationale.fr

www.elysee.fr

www.legifrance.gouv.fr

\section{México}

www.shcp.gob.mx

www.diputados.gov.bx

www.portaltransparencia.gob.mx

\section{Portugal}

www.dgo.pt

www.parlamento.pt 